\author{
UNIVERSIDADE DE SÃO PAULO \\ CAMPUS DE SÃO CALOS
}

\title{
ANÁLISE DA EVOLUÇÃO DOS PROCESSOS EROSIVOS ACELERADOS EM ÁREAS URBANAS E DAS TÉCNICAS DE CONTROLE E RECUPERAÇÃO - CÓRREGO DO TUCUM (SÃO PEDRO/SP)
}

Marcilene Dantas Ferreira

Dissertação apresentada à Escola de Engenharia de São Carlos da Universidade de São Paulo, para concorrer ao Título de Mestre, pelo curso de Pós-Graduação em Engenharia Civil - Área de concentração: Geotecnia.

Orientador: Prof. Dr. Osni José Pejon

São Carlos 
Ficha catalográfica preparada pela Seção de Tratamento da Informação do Serviço de Biblioteca - EESC/USP

Ferreira, Marcilene Dantas

Análise da evolução dos processos erosivos acelerados em áreas urbanas e das técnicas de controle e recuperação : córrego do Tucum (São Pedro/SP) / Marcilene Dantas Ferreira. -São Carlos, 2004.

Dissertação (Mestrado) -- Escola de Engenharia de São Carlos-Universidade de Săo Paulo, 2004.

Área: Geotécnia.

Orientador : Prof. Dr. Osni José Pejon

1. Processos erosivos. 2. Voçoroca. 3. Evolução.

4. Técnica de controle. 5. Caracterização. I. Título. 
FOLHA DE JULGAMENTO

Candidata: Geóloga MARCILENE DANTAS FERREIRA

Dissertação defendida e julgada em 04-06-2004 perante a Comissão Julgadora:

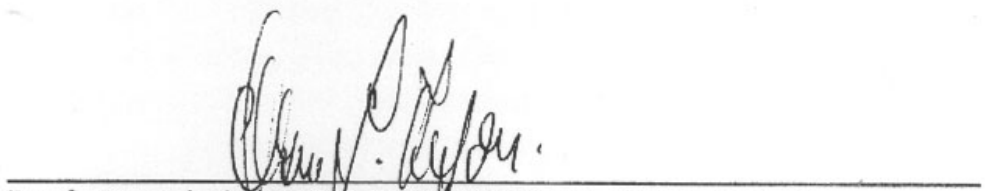

Prof. Associado OSN JOSE PEJON (Orientador)

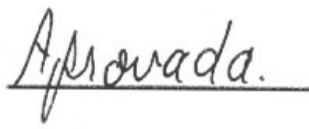

(Escola de Engenharla de Săo Carlos/USP)

fuy Snshavin:

Prof. Dr. LUIZ NISHIYAMA

Arrovada

(Universidade Federal de Uberlândia/UFU)

$\frac{\text { Demia P. Wen }}{\text { Dra. DENISE BALESTRERO MENEZES Aprorado }}$ (Geoprocessamento e Meio Ambiente/PROGEO)

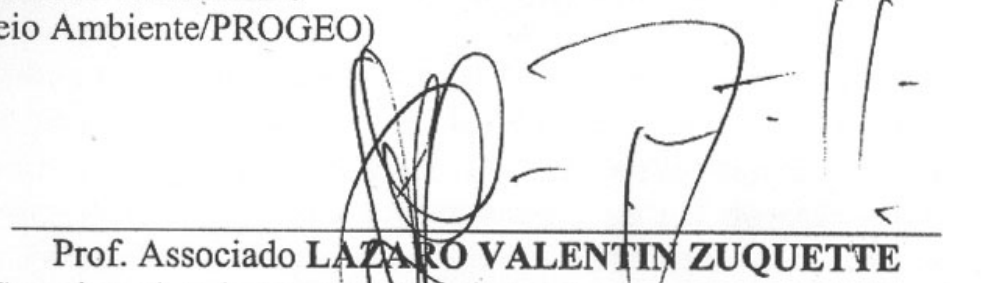

Coordenador do Progranda de Pós-Gradưação em Geotecnia

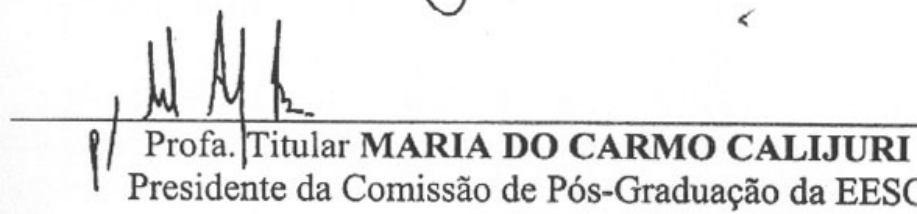


DEDICATÓRIA

Aos meus pais (Lucivaldo de Andrade Ferreira e Elza Dantas Ferreira), a verdadeira razão da minha vida. Por serem um exemplo de caráter, dignidade e dedicação.

Obrigada!!!! 


\section{AGRADECIMENTOS}

A DEUS, pela luz dada nos momentos mais difíceis, que mesmo eu não merecendo, sempre me envolve com todo seu amor.

Aos meus irmãos e cunhado(a)s (Marcelo e Vânia; Vera e Antonio) e meus sobrinhos filhos (Yan e Victoria) e toda minha família, por serem os grandes responsáveis por essa conquista, transformando o impossível em simples, para fazer desta etapa de minha vida uma caminhada sem obstáculos.

Ao Prof. Dr. Osni José Pejon, inicialmente por ter aceitado a proposta deste trabalho, e depois por ter orientado com extrema dedicação e compreensão a execução do mesmo, elucidando com clareza todas as dúvidas que apareceram durante a realização deste e amizade conquistada a partir deste trabalho.

Aos professores do departamento pela amizade e ricas discusões nos temas mais diversas no cafezinho e fora dele.

Ao Departamento de Geotecnia da Escola de Engenharia de São Carlos-USP, pela infra-estrutura laboratorial, sem a qual este trabalho não seria possível. A aos funcionários Maristela, Álvaro, Neiva, Toninho e Herivelto, e os técnicos do laboratório, Zé Luiz, Oscar, Décio, Benedito, Silvio, Klever e seu Antonio, pela dedicação, auxílio e a verdadeira amizade conquistada durante o desenvolvimento do mestrado.

Ao meu Amigo Ademar pela preciosa colaboração, ajuda e dedicação na etapa de campo.

À Coordenaria de Aperfeiçoamento de Pessoal de Nível Superior - CAPES pelo apoio financeiro para realização desse mestrado.

A prefeitura Municipal de São Pedro nas pessoas do Secretário Municipal de Agricultura, abastecimento e Meio Ambiente e do presidente do conselho de Defesa Civil de São Pedro (COMDEC).

As amigas, moradoras da república 21B: Msc Aristotelina Ferreira da Silva (grande amiga e colaboradora, pela ajuda, dedicação, estimulo e apoio em todos os momentos em São Carlos) e a minha irmã Geóloga Fernanda de Figueiredo Damasceno, pela força irrestrita nos momentos difíceis, amizade e contribuição para o desenvolvimento deste trabalho. Os amigos da república Gisele (uma grande colaboradora e companheira de mestrado) e Myrko por terem me recebido em São Carlos com tanto afeto, hospitalidade e carinho, além dos maravilhosos almoços paraenses.

Ao meu, acima de tudo grande amigo Henry Willy Revilla Amezquita (Bicho!!!!!), pelos laços de amizade, companheirismo e carinho sedimentados durante estes anos de mestrado, por sempre me fazer acreditar que conseguiria conquistar meus objetivos na vida.

Aos colegas da pós-graduação, em especial aos companheiros de turma e do mapeamento geotécnico, pelos bons momentos e pela força ao longo do mestrado.

Aos amigos que deixei em Belém e que não esqueceram da amiga em São Carlos: Francisco, Simone, Fabio, Uchõa, seu Chico e Cinira.

A brisa sincera que encontrei aqui, que sempre aqueceu meu coração nos momentos mais difíceis.... Obrigada.

Enfim, a todos aqueles que de uma forma ou de outra colaborarão com este trabalho e participaram da minha vida nesse período. 
Não existem erros, apenas lições. 0 crescimento é um processo de tentativa $e$ erro: experimentação. As experiências que não deram certo fazem parte do processo, assim como as bem-sucedidas. As respostas estão dentro de você. Tudo o que tem a fazer é analisar, ouvir e acreditar (autor desconhecido).

A força não provém da capacidade física $e$ sim de uma vontade indomável. (Mahatma Gandhi) 


\section{SUMÁRIO}

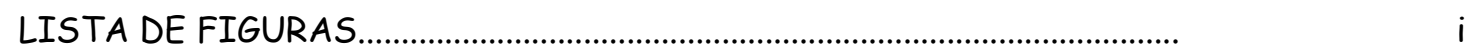

LISTA DE TABELAS .................................................................................

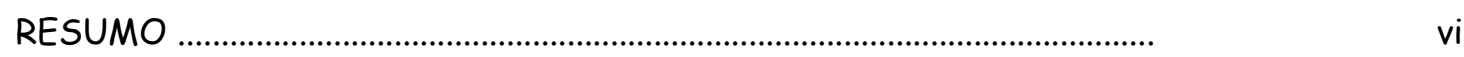

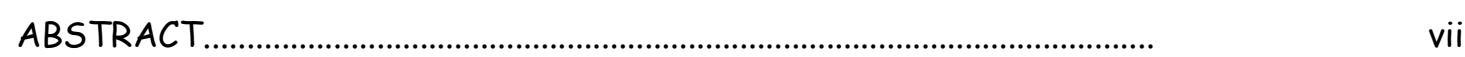

1 INTRODUÇÃO

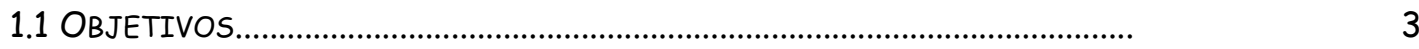

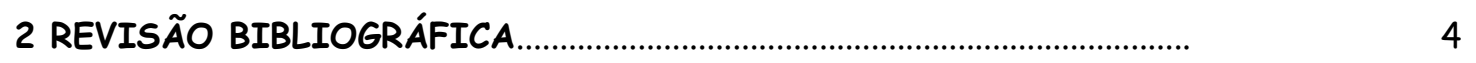

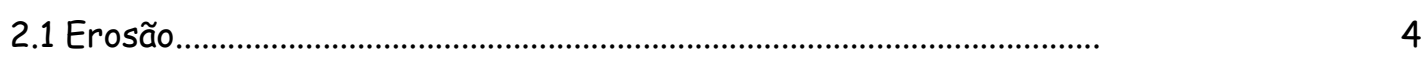

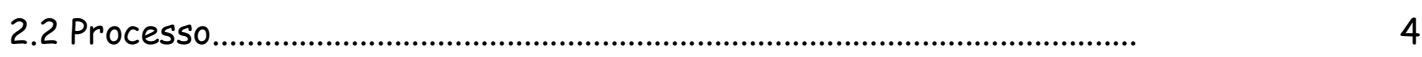

2.2.1 Fatores influentes no processo erosivo 4

$\begin{array}{ll}\text { 2.2.2 Estimativa de erosividade e erodibilidade } & 7\end{array}$

2.3 Tipos de Feições 9

2.4 Zona de ocorrência 12

2.4.1 Erosão urbana 12

2.4.2 Impactos decorrentes da erosão urbana 13

$\begin{array}{ll}2.5 \text { Evolução das voçorocas } & 15\end{array}$

2.6 Degradação por processos erosivos $\quad 17$

$\begin{array}{ll}2.6 .1 \text { Aspectos gerais } & 17\end{array}$

2.6.2 Custos da recuperação de áreas degradadas por processos erosivos $\quad 19$

2.7 Técnicas de controle de erosão urbana 21

2.7.1 Obras de disciplinamento do fluxo de água 24

2.7.1.1 Microdrenagem $\quad 25$

2.7.1.2 Macrodrenagem $\quad 27$

2.7.2 Obras de contenção de taludes 34

2.7.3 Revegetação 34

2.7.4 Obras de aterramento 36

2.7.5 Obras de barramento $\quad 37$

$\begin{array}{ll}2.7 .6 \text { Terraceamento } & 38\end{array}$ 
2.7.7 Obras complementares

2.7.7.1 Obras de pavimentação

2.7.7.2 Drenos $\quad 42$

2.7.6.3 Geossintéticos $\quad 43$

2.7.7.4 Lixo como medida corretiva 46

$\begin{array}{ll}\text { 2.7.7.5- Gabiões } & 47\end{array}$

2.7.7.6- Mapeamento/ Cartografia geotécnica $\quad 47$

$\begin{array}{ll}\text { 2.7.8 Obras auxiliares de proteção } & 47\end{array}$

2.7.9 Exemplos de técnicas de controle aplicadas 48

2.8 Mapeamento geotécnico e Geoprocessamento para erosão 53

2.9 Métodos de determinação de vazão em obras de erosão urbana 57

2.9.1 Método Racinal 57

2.9.2 Método U.S. Soil Conservation Service 64

3 MATERIAIS E MÉTODOS 66

3.1 Aspectos Gerais 66

3.2 Trabalhos de escritório 66

3.3 Trabalhos de campo 68

3.4 Trabalhos de laboratório 69

3.5 Elaboração dos documentos cartográficos 72

4 CARACTERÍSTICAS GERAIS DA ÁREA 73

4.1 Localização e acesso 73

$\begin{array}{ll}4.2 \text { Hidrologia } & 73\end{array}$

4.3 Vegetação $\quad 74$

4.4 Clima $\quad 75$

$\begin{array}{ll}4.5 \text { Geomorfologia } & 75\end{array}$

4.6 Geologia e Materiais inconsolidados $\quad 75$

4.7 Problemas Ambientais 76

5 RESULTADOS

5.1 Documentos Cartográficos Elaborados 78

$\begin{array}{ll}\text { 5.1.1 Mapa base e de documentação } & 78\end{array}$ 
5.1.2 Mapa de feições $\quad 79$

5.1.3 Carta de declividade $\quad 86$

5.1.4 Mapa de materiais inconsolidados $\quad 88$

5.1.5 Mapa de landforms 98

5.1.6 Mapa de microbacias 106

5.1.7 Mapa de localização de obras de controle de erosão 118

5.2 Características Pluviométricas 125

6 DISCUSSÃODOS RESULTADOS 128

6.1 Aspectos pertinentes aos Materiais Inconsolidado 128

6.2 Influência da Declividade no processo 128

6.3 Relação dos landforms com os processos erosivos 129

6.4 Uso e Ocupação como aspectos modificadores 129

6.5 Índices Pluviométricos e processos erosivos 130

6.6 Análise das técnicas de controle utilizadas 130

6.6.1 Avaliação Econômica dos Custos de obras de controle de Erosão Urbana 132

6.6.2 Avaliação Ambiental e eficiência das obras de controle de Erosão Urbana

6.7 Evolução das feições e Uso e Ocupação

7 CONCLUSÕES E RECOMENDAÇÕES

8 REFERÊNCIAS BIBLIOGRÁFICAS

ANEXO I - MAPA BASE E DE DOCUMENTAÇÃO

ANEXO II - MAPAS DE FEIÇÕES EROSIVAS

ANEXO III - CARTA DE DECLIVIDADE

ANEXO IV - MAPA DE MATERIAIS INCONSOLIDADOS

ANEXO V - MAPA DE LANDFORMS

ANEXO IV - MAPA DE MICROBACIAS

ANEXO VII - MAPA DE LOCALIZAÇÃO DE OBRAS DE CONTROLE DE EROSÃO 


\section{LISTA DE FIGURAS}

FIGURA 2.1 Fatores e Causas dos processos erosivos LAL (2001).

FIGURA 2.2 Vista geral de feições erosivas do tipo Sulco

Fonte: http://www.netc.net.au/enviro/fguide/sheeterosion.html

FIGURA 2.3 Vista geral de feições erosivas do tipo Ravina

Fonte: http://www.netc.net.au/enviro/fguide/gullero.html

FIGURA 2.4 Voçoroca localizada no município de São Pedro (SP)

FIGURA 2.5 estágio inicial da evolução de feições erosivas (Fiore \& Soares, 1976).

FIGURA 2.6 estágio intermediário da evolução de feições erosivas (Fiore \& Soares, 1976).

FIGURA 2.7 estágio final ou maduro da evolução de feições erosivas (Fiore \& Soares, 1976).

FIGURA 2.8 lançamento do sistema de drenagem na meia encosta sem execução de um dissipador de energia (DAEE, 1990).

FIGURA 2.9 Execução de obras de disciplinarmente do fluxo para contenção de voçoroca de São Pedro/SP

FIGURA 2.10 Exemplo de dissipação tipo mergulho (Pontes, 1980 e Frendrih, 1997).

FIGURA 2.11 Tipos de estruturas de Barragens (Bertoni \&Lombarde Neto, 1999)

FIGURA 2.12 Sistema de Barragens Escalonadas (Ridente \& Almeida Filho, 1998). 30

FIGURA 2.13 Esquema de retaludamento com cobertura vegetal com grama (IPT, 1991)

FIGURA 2.14 com esquema de pequeno barramento projetado em uma voçoroca com vertedor tipo cachimbo ou tulipa (DAEE, 1990).

FIGURA 2.15 Representação em bloco diagrama do terraço tipo Nichols $(A) e$ Representação em bloco diagrama do terraço tipo Base larga (B) Almeida \& Ridente Jr. (2001)

FIGURA 2.16 Representação em bloco diagrama do terraço tipo patamar Almeida \& Ridente Jr. (2001).

FIGURA 2.17 Esquema de Dreno Cego (DAEE, 1990)

FIGURA 2.18 Esquema de Dreno de Bambu (DAEE, 1990)

FIGURA 2.19 Exemplo de obras auxiliares de proteção (DAEE, 1990)

FIGURA 2.20 Mostra uma vista parnoramica tela ARP430, nos taludes da siderúrgica, em 15(a) e 77(b) dias respectivamente depois de implantada a tela.

FIGURA 2.21 Procedimento de análise para planejamento da erosão do solo (ARONOFF, 1991 apUd MENEGUETTE, 2000).

FIGURA 3.1 Fluxograma das atividades e documentos elaborados. 
FIGURA 3.2 Esquema do ensaio de absorção de água.

FIGURA 4.1 Localização da cabeceira da bacia do córrego Tucum

FIGURA 5.1 vista da encosta do loteamento Recanto das Águas em 1980, observar que ela esta completamente sulcada, com indicado pela seta (Oka-Fiori,1980).

FIGURA 5.2 encosta direita do Dimas, observa os cordões de nível $e$ as reativações do tipo sulcos em alguns pontos. As setas mostram pontos de reativação

FIGURA 5.3 com as chuvas de Março de 1995, o nível do córrego do Tucum subiu formando uma represa, que acabou rompendo o aterro sobre qual passava a SP-191.

FIGURA 5.4 Casa afetada pela reativação da ravina aterradas na encosta do canal do Dimas. Em dezembro de 2000.

FIGURA 5.5 Vista aérea de baixa altitude de parte da área, observa-se que em 2001, a voçoroca com ravina, localizada na favela Raia foi controlada pela construção de cordões e encontrava-se estável.

FIGURA 5.6 Nesta foto observa-se a reativação voçoroca do Recanto, que foi recuperada com aterramento

FIGURA 5.7 Nesta foto observa-se a nova voçoroca formada pelo rompimento da obras de águas pluviais.

FIGURA 5.8 distribuição das unidades de materiais inconsolidados em foto aérea, após serem delimitadas em campo.

FIGURA 5.9 (a) Tipos de Materiais inconsolidados representativos das unidades 1 e 8, Feição erosiva do Dimas (Ponto P2-06) e (b) mostra a lente arenosa, esta é um ponto de fragilidade do pacote de materiais

FIGURA 5.10 Materiais inconsolidados representativos das unidade2, instalados no final do canal da feição erosiva do Dimas.

FIGURA 5.11 tipos de Materiais inconsolidados representativos da unidade 3 (e arenito amarelado no talvegue do canal do Tucum

FIGURA 5.12 Materiais inconsolidados representativos da unidade 4, localizado na favela Raia: a)talude ( $R+3, R s 3$ e Ra1), b)encosta esquerda ( $R+5$ e $L$ material conglomerático) e c) Encosta direita (R+5,Rs2 e Rs3).

FIGURA 5.13 Materiais inconsolidados representativos da unidade 5, 6, 11, 12 e 14 localizado entre o leito do canal do Tucum e a Fazenda.

FIGURA 5.14 (A) material inconsolidado representativo da unidade 10, localizado na margem da estrada de terra São Pedro-Charqueada e (B) exemplo de ocorrência do material $R+7$, que se localiza abaixo da linha de seixos, na transição entre os materiais retrabalhados e os residuais.

FIGURA 5.15 observar o uso e ocupação, que deixa poucas porções do material $R+3$ ainda exposto.

FIGURA 5.16 Aplicação da técnica de avaliação do terreno, modificada de Cooke \& Doornkam (1990), apud Lollo (1996).

FIGURA 5.17 Modelo digital de terreno sobreposto à fotografia aérea de 1962 , indicando o posicionamento espacial dos landforms, gerado a partir do software Envi@ 3.6 as setas mostram as unidades

FIGURA 5.18 Figura 5.18: Observar nesta foto de 1992, a situação de alguns unidade e elementos de landforms (F, A1, A4, A5 e E1) 
FIGURA 5.19 Encosta Direita do Canal do Dimas, nesta pode-se observar os 102 landfoms C3,C4 e C5, em 2003.

FIGURA 5.20 Observar os seguintes landforms da unidade D (D1, D2 e D3 ) na área da favela Raia, em 2003. Estes se encontram completamente 102 alterados.

FIGURA 5.21 Nesta foto podemos observar os landforms A5, E1, E2 e F em 2003103

FIGURA 5.22 Modelo digital de terreno sobreposto à fotografia aérea de 1978, indicando o posicionamento espacial dos landforms, gerado a partir do software Envi@ 3.6 as setas mostram a unidade $E$ e os elementos E2 e E3.

FIGURA 5.23 Modelo digital de terreno sobreposto à fotografia aérea de 2000, indicando o posicionamento espacial dos landforms, gerado a partir do software Envi@ 3.6 as setas mostram as unidades de elementos de terreno alterados pelas obras de controle executadas na 105 cabeceira do córrego do Tucum

FIGURA 5.24 área urbana e sistema de galerias de águas pluviais (Righetto, 1998). 107

FIGURA 5.25 Distribuição das vazões em $\left(\mathrm{m}^{3} / \mathrm{s}\right)$ nas diversas bacias, simuladas para os 12 eventos de chuva ( $A$ ) Bacias do São Dimas e (B) Bacias doa Favela Raia

FIGURA 5.26 Distribuição das vazões em $\left(\mathrm{m}^{3} / \mathrm{s}\right)$ nas diversas bacias, simuladas para os 12 eventos de chuva das bacias da Florestal (A) e Fazenda (B).

FIGURA 5.27 Distribuição das vazões em ( $\left.\mathrm{m}^{3} / \mathrm{s}\right)$ nas diversas bacias, simuladas para os 12 eventos de chuva nas Bacias do Tucum, próximo a SP-191.

FIGURA 5.28 Distribuição das vazões em $\left(\mathrm{m}^{3} / \mathrm{s}\right)$ nas diversas bacias, simuladas para os 12 eventos de chuva versus chuvas totais $(B)$ e as diversas durações (B) dos 12 eventos.

FIGURA 5.29 observa-se a construção do Terraceamento em nível (murundus) em 1992 (Pejon e Zuquette, 2002)

FIGURA 5.30 observa-se a utilização de lixo como aterro na área da fazenda em 1992

FIGURA 5.31 observar os cordões de nível rompidos em 1995

FIGURA 5.32 observar a canaleta construída no inicio do canal do Dimas, observar que esta acaba levando lixo para a rede de águas pluviais.

FIGURA 5.33 observar os impactos ambientais da disposição de resíduos sólidos em feições erosivas, como procedimento de controle.

FIGURA 5.34 observar a tubulação de águas pluviais totalmente destruída, no 122 canal do Dimas em Dezembro de 2000.

FIGURA 5.35 mostra a vala utilizada para desviar o fluxo de águas pluviais do canal do Dimas em 2000.

FIGURA 5.36 Observar os cordões rompidos $(A)$ e acumulando água $(B)$ no verão de 2004

FIGURA 5.37 mostra a escada dissipadora da margem esquerda do Dimas rompida no inverno de $2002(A)$ e depois de reconstruída (B)

FIGURA 5.38 As medias mensais para o período nov 1942 a julho de 2000, SIGRH (www.sigrh.sp.gov.br).

FIGURA 5.39 Distribuição mensal das chuvas (ao redor 700 meses 126 
analisados) SIGRH (www.sigrh.sp.gov.br).

FIGURA 5.40 Distribuição das intensidades diárias (ao redor de 21000 medidas) SIGRH (www.sigrh.sp.gov.br)

FIGURA 6.1 Fotografias aéreas da área de estudo em 1962 (A), 1972 (B) e 1978 (C) mostrando os principais uso e ocupação do solo, e a evolução 145 das feições erosivas

FIGURA 6.2 Fotografias aéreas da área de estudo em 1988 (A), 1995 (B) e $2000(C)$ mostrando os principais uso e ocupação do solo, e a evolução das feições erosivas.

FIGURA 6.3 mostras a Voçoroca do São Dimas em intensa atividade em nov 2003

FIGURA 6.4 Voçoroca lixão em Jan/2003 antes de seu fechamento e depois de 151 fechado e Aterrado.

FIGURA 6.5 o inicio do canal do São Dimas, passou a ser utilizada como área de deposição de resíduos de construção civil e restos vegetais.

FIGURA 6.6 reativação da voçoroca do Raia devido rompimento do sistema de captação de águas pluviais em Jan/03 (A), esta foi recuperado em Outubro/03 (B).

FIGURA 6.7 voçoroca do Recanto da Águas antes do seu aterramento em Out de 2003 (A) e depois de suas reativação em Março de 2000.

FIGURA 6.8 Colapso das obras de controle de microdrenagem, que depois são reconstruídas. 


\section{LISTA DE TABELAS}

TABELA 2.1 Tabela 2.1 - Atributos deflagradores dos processos erosivos citados por diversos autores como (Bertoni \& Lombardi Neto, 1999; DAEE, 1990; Santos \& Gomes, 1998; Gerra e Cunha, 1995; Selby,1993; Morgam, 1996, Iwasa e Prandini, 1980; Sá, 2001; Rodrigues, 1982; Lal, 1990; Sudo, 1998; Souza, 2001)

TABELA 2.2 Fatores que influenciam na erobilidade do solo modificada de Lal, (1990).

TABELA 2.3 Impactos ambientais da ocupação sobre o meio físico (modificada de Chiossi, 1983) apud Almeida Filho (1998).

TABELA 2.4 Formas de análise, benefício-custo (Porto \& Azevedo, 1997)

TABELA 2.5 Propostas de práticas de controle de processos erosivos em áreas urbanas, modificado de Souza (2001).

TABELA 2.6 Mostrando as vantagens e desvantagens na utilização na utilização de diferentes tipos de barragens

TABELA 2.7 Tipos de vertedor, equação para calculo de Vazão e parâmetros.

TABELA 2.8 Determinação dos tipos de Vertedor, suas vantagens e limitações em seu uso (DNOS, 1992).

TABELA 2.9 tipos de geossintéticos utilizados em obras de controle de erosão (www.tenax.net/geossinteticos/index.htm Vidal, 1995;)

TABELA 2.10 Avaliação de métodos de controle de erosão é sua funcionalidade, custo e tempo de execução e durabilidade da obra

TABELA 2.11 Principais métodos utilizados na identificação de feições erosivas (Souza, 2001).

TABELA 2.12 Coeficiente C (cidade de Austin, Texas, USA, citado em Chow, 1962 apud Genovez, 2003)

TABELA 2.13 Coeficiente C (ASCE, 1969 apud Tucci, 1993)

TABELA 2.14 Coeficiente C (ASCE/WEF, citado em Chow, 1962 apud Genovez, 2003)

TABELA 2.15 Valores de coeficiente de Maning (Tucci,1993)

TABELA 2.16 velocidade médias aproximadas do escoamento superficial para cálculo de tc,em $\mathrm{m} / \mathrm{s}$. Texas Highway departament,1970

TABELA 2.17 períodos de retorno para obras de microdrenagem com diferentes tipos de ocupação (DAEE/CETESB,1980)

TABELA 3.1 Ensaios laboratoriais realizados.

60

TABELA 5.1 Resultado geral do cadastro das feições erosivas

TABELA 5.2 Classes de Declividades adotadas para a área da Bacia do Córrego Tucum

TABELA 5.3 Resultados dos ensaios laboratoriais 90

TABELA 5.4 Resultados dos ensaios laboratoriais e em in situ 91 
TABELA 5.5 Tabela da SCS com valores de $C N$ para alguns tipos de solo,associados a tipos de uso e ocupação. Os tipos de solo seguem a seguinte classificação: Grupo A - solo arenosos profundos com baixo teor de argila; Grupo B- solo arenosos rasos com baixo teor de argila; Grupo $C$ - solos barrentos com teor de argila entre $20 \mathrm{e}$ $30 \%$ e Grupo D-solos argilosos (Righetto, 1998).

TABELA 5.6 Vazões de pico para cada ponto específicas dentro das microbacias (calculado pelo método da SCS, citado em Righetto, 1998).

TABELA 5.7 Vazões de pico para cada ponto específicos de microbacias para 112 diversos eventos de chuvas típicos para a área.

TABELA 5.8 Diâmetros de tubulações para vazões de pico de 4 cenários para as seções das microbacias.

TABELA 6.1 planilha de custo de obras de combate a erosão bairro São Dimas, dados cedidos pela prefeitura municipal de São Pedro- Secretaria de Planejamento

TABELA 6.2 planilha de custo de obras de combate a erosão bairro São Dimas, dados cedidos pela prefeitura municipal de São Pedro- Secretaria 135 de Planejamento

planilha de custo de obras de combate a erosão bairro São Dimas, dados cedidos pela prefeitura municipal de São Pedro- Secretaria de Planejamento.

TABELA 6.4 Categorias de formas de uso e ocupação do solo e problemas/ processos do meio físico segundo Almeida \& Freitas (1996). 


\section{LISTA DE ABREVIAÇÕES E SIGLAS}

\begin{tabular}{|c|c|}
\hline ABGE & ASSOCIAÇÃOO BRASILEIRA DE GEOLOGIA DE ENGENHARIA E AMBIENTAL \\
\hline ABNT & ASSOCIAÇÃo BRASILEIRA DE NORMAS TÉCNICAS \\
\hline ASTM & AMERICAN SOCIETY FOR TESTING AND MATERIALS \\
\hline CTC & Capacidade de Troca Catiônica \\
\hline DAEE & Departamento de ÁGuas E Energia ElÉtrica (Estado De São PaUlo) \\
\hline DNOS & DEPARTAMENTO NACIONAL DE OBRAS E SANEAMENTO \\
\hline DNPM & DEPARTAMENTO NACIONAL DE PRODUÇÃo Mineral \\
\hline EESC & Escola De EngenHaria DE SÃo CaRlos \\
\hline EIA & ESTUDO DE IMPACTO AMBIENTAL \\
\hline EUPS & EQUAÇÃo UNIVERSAL DE PERDA DOS SOLOS \\
\hline GPS & GLOBAL POSITION SYSTEM \\
\hline IAEG & INTERNATIONAL ASSOCIATION FOR ENGINEERING GEOLOGY AND THE ENVIRONMENT \\
\hline IBC- GERCA & LEVANTAMENTOS AEROFOtogramÉtricos, Estado de S. PaUlo \\
\hline IBGE & INSTITUTO BRASILEIRO DE GEOGRAFIA E ESTATÍSTICA \\
\hline IG & INSTITUTO GEOLÓGICO \\
\hline IPT & INSTITUTO DE PESQUisas TECNOLÓGICAS Do Estado DE SÃo PaUlo \\
\hline MDT & MODELO DigItAL DE TERRENO \\
\hline NA & NÍVEL DE ÁGUA \\
\hline NBR & NORMA BRASILEIRA \\
\hline PRAD & PLANO DE RECUPERAÇÃo De ÁREAS DEGRADADAS \\
\hline RIMA & RELATÓRIO DE IMPACTO AMBIENTAL \\
\hline SAA & SECRETARIa Da AGRICULTURA E ABASTECIMENTO Do Estado De São PAULO \\
\hline SAS & STATISTICAL ANALYSIS SYSTEM \\
\hline SEMAE & SERVIÇO MUNICIPAL DE ÁGUA E EsGOto \\
\hline SIG & SISTEMA DE INFORMAÇÃO GEOGRÁFICA \\
\hline SSSA & SOIL SCIENCE SOCIETY OF AMERICAN \\
\hline USGS & UNITED STATES GEOLOGICAL SURVEY \\
\hline USP & UNIVERSIDADE DE São PAULO \\
\hline UTM & UNIDADE TRANSVERSO MERCATOR \\
\hline
\end{tabular}




\section{RESUMO}

FERREIRA, M. D. Análise da evolução dos processos erosivos acelerados em áreas urbanas e das técnicas de controle e recuperação - córrego do Tucum (São Pedro/SP). 2004. Dissertação Mestrado - Escola de Engenharia de São Carlos, Universidade de São Paulo, São Carlos.

O presente trabalho apresenta uma análise dos processos erosivos existentes e da evolução das feições erosivas das cabeceiras da bacia do córrego do Tucum em São Pedro/SP, desde 1962 até os dias atuais, assim como das várias técnicas de controle aplicadas na área. Dentro do contexto do estudo procurou-se analisar os fatores que influenciaram na formação destas feições por meio de: fotointerpretação, ensaios de caracterização básica dos solos, erodibilidade e cisalhamento direto; trabalho de campo para mapeamento dos materiais geológicos, cadastro das feições, uso e ocupação e ensaios de infiltração. As feições existentes na área foram enquadrados em três estágios evolutivos, assim caracterizados como: $1^{\circ}$ Estágio- feições pré $1962,2^{\circ}$ Estágio- feições 1962-1988 e $3^{\circ}$ Estágio- feições 1988-2003. Os resultados de estudos de campo e laboratorial permitiram classificar os materiais inconsolidados como arenosos e foram individualizados em 15 tipos, que foram agrupados em 14 unidades em função do arranjo espacial dos tipos. Estes materiais apresentaram-se muito permeáveis ( $\cong \cong 10^{-3} \mathrm{~cm} / \mathrm{s}$ ), com alta erodibilidade, com ângulo de atrito 23 a $25^{\circ}$, coesão 11 a $18 \mathrm{kPa}$, CTC baixa e superfície especifica menor que $20 \mathrm{~m}^{2} / \mathrm{g}$. Com base nos resultados obtidos verificou-se que atualmente a área ainda encontra-se com processos erosivos ativos e novas feições têm sido instaladas, apesar das várias tentativas de controle, que em muitos casos foram subdimencionadas. Este estudo concluiu, também, que o conhecimento dos aspectos pertinentes aos materiais inconsolidados, a declividade, landforms, uso e ocupação e índices pluviométricos são fundamentais para compreensão da evolução dos processos, que combinados com 0 conhecimento das técnicas de controle já utilizadas, proporcionam a formulação de medidas preventivas, de controle e recuperação mais adequadas.

Palavra-chave: Processos erosivos, Voçoroca, Evolução, Técnica de controle e Caracterização Geotécnica, 


\begin{abstract}
Analysis of the evolution of the accelerated erosion processes in urban areas and rehabilitation and control procedures. Córrego do Tucum ( São Pedro/SP). 2004

Dissertação Mestrado - Escola de Engenharia de São Carlos, Universidade de São Paulo, São Carlos.
\end{abstract}

This work presents an analysis of the erosive processes and their evolution in the head part of the Córrego do Tucum basin, since 1962 until nowadays, as well as of the erosion control procedures used in the area. This study is based on several kinds of works, such as: photointerpretation, laboratorial tests (basic geotechnical, erodibility, direct shear test) and field works for geological materials mapping, erosion features inventory, assessment of uses and occupation types and infiltration tests. The erosion features were classified into 3 groups: First, before 1962, second between 1962 and 1988 and third between 1988 and 2003. The results obtained from laboratorial and field works permitted to define 15 unconsolidated materials types arranged into 14 spatial units. These materials are very sandy, presenting high permeability $\left(k \sim 10^{-3} \mathrm{~cm} / \mathrm{s}\right)$, high erodibility index, cohesion between 11 and $18 \mathrm{kPa}$, angle of internal friction varying between 23 and $25^{\circ}$, low cationic exchange capacity and specific surface less than $20 \mathrm{~m}^{2} / \mathrm{g}$. It was observed in the area active erosion features as well as new erosion features, despite of several tentative of control. But most part of the control procedures were inadequate due to absence of adequate geological and geotechnical studies. This work permitted to conclude that information about unconsolidated material, slopes, landforms, rainfall and uses and occupation types are the main point to design adequate erosion control procedures.

Keywords: Erosive process, gully, control procedures, geotechnical characterization, São Pedro, Brazil 


\section{INTRODUÇÃO}

O conhecimento do estado da erosão e de seu impacto ambiental e o prognóstico de sua evolução com base na definição da suscetibilidade dos terrenos associado ao uso $e$ ocupação são imprescindíveis à definição das ações governamentais tais como: estabelecer prioridades para as áreas de aplicação de investimentos em obras corretivas, orientar a expansão urbana, definir as adequações necessárias à implantação de obras viárias que atravessem áreas de alta suscetibilidade à erosão, e outras.

As feições decorrentes de processos erosivos acelerados no Brasil ocorrem em grande número e estão distribuídas em toda sua extensão territorial. Por esta razão os estudos de evolução destas feições são de grande importância, pois permitem compatibilizar a tomada de decisão, com o uso de técnicas que poderão ser aplicadas para seu controle de forma mais prática e eficaz.

A propagação e instalação destas feições dependem das características do meio físico e do uso e ocupação do solo. Normalmente os estudos de evolução dos processos erosivos são desenvolvidos a partir da análise dos registros temporais com uso dos sensores remotos e de trabalho prévios, associados a trabalho de campo e estudos laboratoriais.

O corriqueiro investimento em soluções inadequadas e paliativas no controle real da erosão urbana é um problema muito sério na atual conjectura mundial, onde este é um grave problema de degradação do solo. Aliado a isso a total falta de um planejamento urbano eficiente e preciso, que leve em consideração os recursos disponíveis e as fases do projeto, acabam por provocar um grande desperdício de dinheiro publico. A falta de mão de obra especializada para conceber o projeto (levando em consideração o processo de formação, evolução e as características particulares de cada erosão) e executá-lo (na instalação dos componentes a macro e micro drenagem, estruturas de contenção, reaterro, etc.), são fatores que agravam o problema. 
No estado de São Paulo um grande número de municípios é afetado por estes processos, implicando, portanto em custos elevados para recuperação e controle destas áreas afetadas (IPT, 1989).

No Município de São Pedro/SP encontram-se diversas áreas afetadas por estes processos, dentre elas a cabeceira da bacia do córrego do Tucum que apresenta registro destes processos desde os anos 1960 e tem sido palco de diversos estudos científicos e de projeto de recuperação e controle. Apesar deste fato o processo continuou ativo com diferentes características e intensidades até os dias atuais. Este estudo contempla uma análise de todos estes trabalhos até então desenvolvidos, assim como desenvolveu trabalhos geológico-geotécnico voltado para um melhor entendimento da evolução das feições erosivas.

Para isso primeiramente foi realizado um levantamento bibliográfico sobre estudos prévios desenvolvidos na área e de outras bibliografias atuais, assim como de mapas, fotografias aéreas e dados pluviométricos. Foram realizadas a fotointerpretação e a análise preliminar da área com relação as suas características gerais. Em seguida foi realizado trabalho de campo para avaliar os resultados da fotointerpretação, definição dos perfis dos materiais inconsolidados e delimitação das unidades. Associados a esta atividade foram avaliados os usos e ocupação do solo, características das feições e registros das técnicas de controle aplicadas.

Após esta atividade foi desenvolvida uma fase de amostragem e de ensaios in situ, sendo obtidas amostras deformadas e indeformadas representativas das unidades de materiais geológicos aflorantes na área e realizados ensaios de condutividade hidráulica com permeametro do tipo Guelphi. Estes materiais geológicos amostrados foram caracterizados através de ensaios de laboratório.

Em seguida desenvolveu-se uma análise de todas as informações obtidas, tendo sido elaborados os seguintes documentos cartográficos: mapa de materiais inconsolidados, mapas de landfoms, carta de declividade, mapa de documentação, mapa de feições erosivas $(1962,1978,1972,1988,1995$ e 2000), mapa e microbacias e mapa de obras de controle de processos erosivos. Finalmente elaborou-se uma análise da evolução dos processos erosivos acelerados e obras executadas para controle e recuperação da área, assim como propôs-se medidas de prevenção e controle, para um melhor planejamento ambiental/territorial da área. 


\section{1 - Objetivos}

Avaliar a evolução dos processos erosivos na área desde 1960, dando ênfase a análise das formas de controle até então utilizadas. Com base neste levantamento e em trabalhos complementares executados nesta pesquisa busca-se propor novos subsídios para controle e de recuperação para as áreas da bacia que tiveram uma recuperação inadequada, bem como para as áreas ainda não recuperadas.

Secundariamente pretende-se avaliar o impacto ambiental provocado por este processo de controle e recuperação, além do custo de uma obra deste porte. Considerando para tanto as diversas classes de erosão e o interesse do poder publico em conter ou recuperar e, em casos de recuperação, qual a nova destinação para área. 


\section{REVISÃO BIBLIOGRÁFICA}

\section{1- EROSÃO}

De acordo com Zachar (1982), a palavra erosão vem do latim, derivada do verbo erodere, que quer dizer comer, escavar, e foi utilizado pela primeira vez por Penck em 1894.

A erosão do solo pode ser dividida em normal e acelerada. A primeira pode ser definida como a erosão que ocorre na superfície terrestre, refletindo uma condição natural de equilíbrio ou como parte do ciclo geológico (denudação). Já a segunda representa o resultado da quebra deste estado de equilíbrio, causado pelo aumento significativo da remoção dos materiais geológicos podendo ser natural ou antrópica (Bennett, 1939 apud Zachar,1982).

Nas regiões tropicais ou subtropicais úmidas, os processos erosivos são provocados principalmente pela ação das chuvas (erosão hídrica) combinada com a ocupação territorial, quase sempre iniciada pelo desmatamento e seguida pelo cultivo agrícola e de pastagens, construção de estradas e caminhos. A formação e expansão de núcleos urbanos, principalmente quando este é feito de forma desordenada $e$ inadequada, configura-se como um desencadeador fundamental $e$ decisivo da origem de processos erosivos acelerados.

\section{2- PROCESSOS EROSIVOS}

\subsection{1- FATORES INFLUENTES NO PROCESSO EROSIVO}

Assim, dentre os fatores mais importantes para desencadeamento destes processos pode-se citar: o índice pluviométrico, susceptibilidade dos materiais geológicos presentes (materiais inconsolidados), forma do relevo (landforms) e uso e ocupação do solo. Sendo que a ação do Homem geralmente é um dos fatores primordiais para o desequilíbrio, destas áreas e início do processo erosivo (Figura 2.1). 
Owoputi \& Stole (2001) apontam duas categorias de fatores que afetam o processo erosivo: fatores erosivos, relacionados com os agentes causadores da erosão (chuva $e$ escoamento superficial), tais como intensidade, freqüência e duração da chuva, topografia e profundidade do fluxo superficial; e fatores relacionados a erodibilidade do solo, tais como a densidade, coesão e tamanho das partículas, e condutividade hidráulica.

Para Selby (1993) esses fatores mostram-se intimamente dependentes uns dos outros e ao mesmo tempo associados Tabela 2.1.

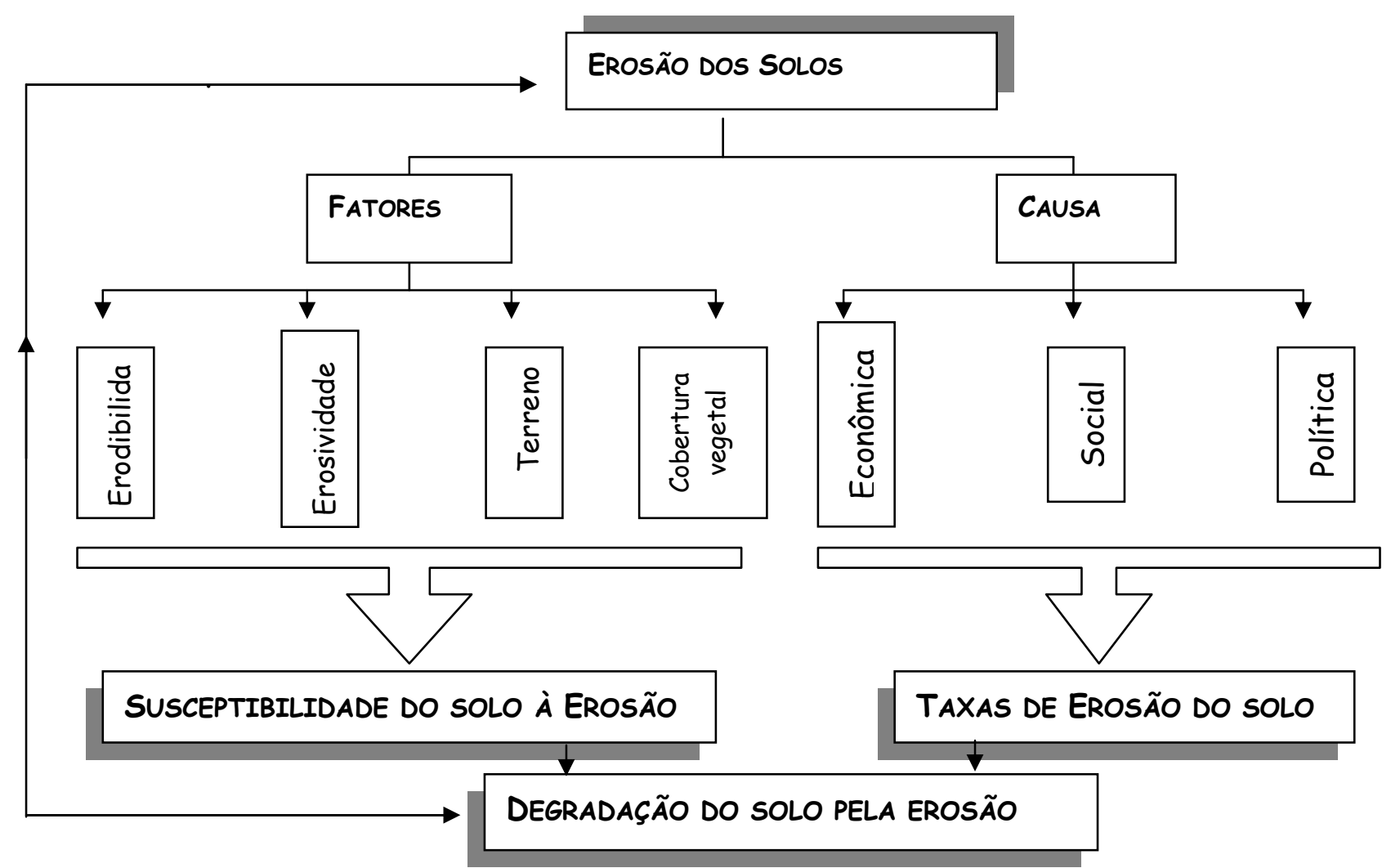

Figura 2.1 - Fatores e Causas dos processos erosivos LAL (2001). 
Tabela 2.1 - Aspectos envolvidos nos processos erosivos citados por diversos autores como (Bertoni \& Lombardi Neto, 1999; DAEE, 1990; Santos \& Gomes, 1998; Gerra e Cunha, 1995; Selby,1993; Morgam, 1996, Iwasa e Prandini, 1980; Sá, 2001; Rodrigues, 1982; Lal, 1990; Sudo, 1998; Souza, 2001)

\begin{tabular}{|c|c|}
\hline FATORES & CARACTERISTICAS \\
\hline Chuva & $\begin{array}{l}\text { - Um dos fatores climáticos de maior importância na erosão dos solos. } \\
\text { - O volume e a velocidade da enxurrada dependem da intensidade, duração e freqüência da } \\
\text { - A intensidade é o fator pluviométrico mais importante na erosão. } \\
\text { - Em regiões tropicais, o efeito de degradação pelo clima esta aliada à precipitação e sua } \\
\text { capacidade de causar erosão. } \\
\text { - São considerados dois agentes erosivos distintos, a gota de chuva e o escoamento } \\
\text { superficial. } \\
\text { - A evolução do processo erosivo esta ligada à quantidade de água excedente que escoa na } \\
\text { encosta; } \\
\text { - Os processos erosivos são mais atuantes e energéticos nos períodos mais chuvosos e por } \\
\text { isso é importante estabelecer os índices pluviométricos para os meses durante o ano; } \\
\text { - A infiltração e o escoamento superficial são dois processos formados a partir da } \\
\text { precipitação pluviométrica e do impacto da gota de chuva, estes contribuem para o } \\
\text { desenvolvimento de uma feição erosiva. }\end{array}$ \\
\hline Topografia & $\begin{array}{l}\text { - Agentes geomorfológico desencadeares na formação de voçorocas devem ser } \\
\text { consideradas, em escala maior: as características típicas das encostas e suas feições } \\
\text { particulares (associadas a litológica local) e em escala menor: processos de modelado } \\
\text { cujos últimos eventos refletem a cobertura vegetal. } \\
\text { - A influência da topografia do terreno na intensidade erosiva manifesta-se principalmente } \\
\text { pela declividade e comprimento da rampa (comprimento da encosta) } \\
\text { - Se a declividade aumenta quatro vezes, a velocidade de escoamento aumenta duas vezes e } \\
\text { a capacidade erosiva quadruplica. }\end{array}$ \\
\hline Natureza do Solo & $\begin{array}{l}\text { - O solo tem um papel essencial nos estudos sobre os mecanismos do processo erosivo, } \\
\text { devido suas características e interação com os outros fatores. } \\
\text { - A degradação das propriedades físicas do solo é um dos principais processos responsáveis } \\
\text { pela perda da qualidade estrutural e aumento da erosão hídrica. } \\
\text { - As propriedades do solo que afetam a erosão são: textura, estrutura, densidade aparente } \\
\text { dos solos, permeabilidade e teor de matéria orgânica. } \\
\text { - As propriedades dos solos exercem diferentes influências na erosão, ao conferir maior ou } \\
\text { menor resistência à ação das águas. }\end{array}$ \\
\hline Cobertura Vegetal & $\begin{array}{l}\text { - A vegetação desempenha um papel importante, pois promove uma distribuição mais difusa } \\
\text { da água de escoamento pluvial, dificultando a instalação da erosão; } \\
\text { - Em terrenos descobertos, a enxurrada faz desprender e salpicar as partículas de solo, que } \\
\text { são facilmente transportadas pela água; } \\
\text { - Ao decompor-se, aumenta o conteúdo de matéria orgânica e de húmus do solo, melhorando- } \\
\text { lhe a porosidade e a capacidade de retenção de água. }\end{array}$ \\
\hline Ação Antrópica & $\begin{array}{l}\text { - É o principal fator na deflagração dos processos erosivos. } \\
\text { - A intervenção humana no meio, com o desmatamento, seguido ou não de exploração } \\
\text { econômica, implantação de obras civis e/ou núcleos urbano altera sua estabilidade. } \\
\text { - A readaptação à nova condição se manifesta na força de intensificação dos processos } \\
\text { erosivos. } \\
\text { - A modificação das encostas provoca alterações significativas na relação escoamento } \\
\text { superficial/armazenamento hídrico do solo, provocando alterações na bacia. } \\
\text { - As seguintes atividades influenciam no desencadeamento dos processos erosivos: ocupação } \\
\text { desordenada das encostas e fundo de vales, construção de barragens e desmatamentos. }\end{array}$ \\
\hline
\end{tabular}




\subsection{2- ESTIMATIVA DE EROSIVIDADE E ERODIBILIDADE}

\section{- EROSIVIDADE}

Oduro-Afriyie (1996) afirma que a expressão mais comum da erosividade é um índice baseado na energia cinética e no momento do escoamento superficial. Assim este mesmo autor complementa enfatizando que o índice de erosividade é função da intensidade e duração da chuva, da massa, diâmetro e velocidade das gotas de chuva.

Zuquette (1987), utiliza o termo erosividade como sendo a capacidade de erosão da chuva. Assim, segundo Nishiyama (1995), parte da erosividade da chuva é devida ao impacto direto da gota de chuva, e parte ao escoamento superficial. A capacidade da chuva em causar erosão do solo é atribuída à sua intensidade e ao tamanho de suas gotas, os quais determinam a energia da chuva.

\section{- ERODIBILIDADE}

A erodibilidade do solo representa o efeito integrado dos processos que regulam a infiltração de água e a resistência do solo á desagregação e transporte (Lal 1988). É, portanto o fator que tem despertado maior interesse nas pesquisas sobre erosão, por ser governada pelos atributos intrínsecos do solo, os quais podem variar de solo para solo e com o tipo de manejo (Silva et al., 2000).

Segundo Zuquette (1987), as condições do solo recebem a denominação de erodibilidade, ou seja, sua vulnerabilidade à erosão. Tal vulnerabilidade é função das características físicas do solo e do seu uso. De acordo com Owoputi \& Stole (2001) existem vários fatores que podem reduzir a erodibilidade dos solos como: compactação do solo pelo impacto das gotas da chuva, maior profundidade do fluxo e uma menor declividade na zona erodida.

Segundo Bryan (2000), as propriedades que determinam a erodibilidade, tais como a agregação do solo e a resistência ao cisalhamento, são fortemente afetadas por fatores climáticos como a distribuição pluvial e a ação do congelamento e descongelamento.

De acordo com Pejon (1992), vários métodos, empíricos em sua maioria, procuram caracterizar a erodibilidade do solo, mas nenhum destes conseguiu uma identificação total dos materiais erodíveis, onde os melhores resultados se situaram em torno de $80 \%$. Este autor fez uma avaliação sobre vários trabalhos é definiu que, o que apresentava melhor resposta era o critério proposto por Nogami \& Villibor (1979), pois o mesmo apresentou as seguintes vantagens: utilização de amostras indeformadas, considera o efeito da secagem, permite inferir as propriedades de desagregabilidade e infiltração, facilidade e rapidez de 
execução e não necessita de equipamentos sofisticados. Lal (1990) levantou vários fatores que influem na erodibilidade dos solos, como pode ser visto na Tabela (2.2).

Tabela 2.2 - Fatores que influenciam na erobilidade do solo modificada de Lal, (1990).

\begin{tabular}{|c|c|c|}
\hline \multicolumn{3}{|c|}{ FATORES QUE INFLUEM NA ERODIBILIDADE } \\
\hline PROPRIEDADES & FATORES & CARACTERISTICAS \\
\hline \multirow{4}{*}{ Mecânicas } & Textura & $\begin{array}{l}\text { - Influi no destacamento e carreamento de partículas do solo; } \\
\text { - Determina a facilidade com que o solo é dispersado; } \\
\text { - Determina a força limite necessária para o destacamento; }\end{array}$ \\
\hline & Estrutura & $\begin{array}{l}\text { - Formação de agregado que resistem á dispersão, aos efeitos } \\
\text { abrasivos da água de escoamento e ao destacamento; } \\
\text { - Grau de agregação e distribuição de agregados estáveis; } \\
\text { - Tamanho dos agregados; }\end{array}$ \\
\hline & $\begin{array}{l}\text { Tamanho dos torrões e } \\
\text { cultivo do solo }\end{array}$ & $\begin{array}{l}\text { - Superfície rugosa e cheia de torrões, possue elevado capacidade } \\
\quad \text { de detenção; } \\
\text { - Resistência à desagregação pela chuva e erosão pelo vento; } \\
\text { - Responsável pela alta taxa de escoamento superficial. }\end{array}$ \\
\hline & Formação de crosta & $\begin{array}{l}\text { - Desenvolve-se em solos com baixa porcentagem de matéria } \\
\text { orgânica. }\end{array}$ \\
\hline Resistência & $\begin{array}{l}\text { Resistência ao } \\
\text { cisallhamento }\end{array}$ & $\begin{array}{l}\text { - Importante no destacamento de partículas do solo (impacto e } \\
\text { escoamento superficial) } \\
\text { - Rolamento e deslizamento de grãos. }\end{array}$ \\
\hline \multirow{3}{*}{ Hidrológicos } & Retenção de água & $\begin{array}{l}\text { - O estado de energia da água do solo ou pressão neutra influencia a } \\
\text { resistência ao cisalhamento do solo; } \\
\text { - Resistência do solo ao arrastamento pela água é influenciado pela } \\
\text { umidade inicial; }\end{array}$ \\
\hline & $\begin{array}{l}\text { Transmissão de água no } \\
\text { solo -Infiltração }\end{array}$ & $\begin{array}{l}\text { - Taxa de infiltração determina o maior ou menor volume de } \\
\text { escoamento superficial }\end{array}$ \\
\hline & Permeabilidade & $\begin{array}{l}\text { - Solos com permeabilidade extremamente baixa a moderada geram } \\
\text { mais escamento superficial. }\end{array}$ \\
\hline Reológicas & Sistema solo/água & $\begin{array}{l}\text { - A umidade do solo influi na susceptibilidade á erosão por afetar a } \\
\text { coesão, a resistência ao cisalhamento, consistência e } \\
\text { plasticidade. }\end{array}$ \\
\hline \multirow[t]{2}{*}{$\begin{array}{l}\text { Químicase } \\
\text { Mineralógicas }\end{array}$} & Matéria Orgânica & $\begin{array}{l}\text { - Influencia a distribuição granulométrica, propriedade de retenção } \\
\text { e transmissão de água; } \\
\text { - Fortalece as ligações que estabilizam as unidades estruturais e } \\
\text { mantém um balanço favorável entre retenção e transmissão nos } \\
\text { poros; } \\
\text { - Diminui o efeito da compactação; } \\
\text { - Concentração de matéria orgânica nos micro-agregados } \\
\text { - aumentando a sua resistência á desagregação (slaking) e á } \\
\text { dispersão }\end{array}$ \\
\hline & Argilo-Minerais & $\begin{array}{l}\text { - A estrutura do solo e a sua resistência são influenciadas pela } \\
\text { quantidade e natureza dos argilo-minerais. } \\
\text { - A fração fina do solo interage com materia orgânica para formar } \\
\text { agregados estáveis que resistem ao impacto das gotas da chuva. }\end{array}$ \\
\hline$\frac{\text { Características do }}{\text { perfil }}$ & Diretos ou Indiretos & $\begin{array}{l}\text { - Influem a erosão direta e indiretamente; } \\
\text { - Influem sobre o escoamento subsuperficial de água em } \\
\text { decorrência de mudanças nas propriedades hidrológicas de } \\
\text { horizontes diferentes; } \\
\text { - Influência sobre o crescimento vegetativo. }\end{array}$ \\
\hline
\end{tabular}

Segundo Silva et al. (2000), existem várias maneiras para se determinar a erodibilidade do solo, que podem ser divididas em métodos diretos ou indiretos, a saber: 
métodos diretos: envolve a determinação, em condições de campo (a) é realizado sob chuva natural, o que torna o um método oneroso e muito demorado e o (b) ocorre sob condições de chuva simulada;

método indireto: (c) baseia-se em regressões múltiplas que contenham como variáveis independentes características intrínsecas do solo (morfologia, físicas, químicas e mineralógicas) ou relação destes, que estejam visivelmente correlacionadas com o fator erodibilidade.

\section{3-TIPOS DE FEIÇÕES}

A erosão acelerada segundo diversos autores (Bennett, 1939 apud Zachar,1982; DAEE, 1990; Morgan, 1996; Vandaele, 1996) pode ser de dois tipos, dependendo da forma como o escoamento superficial acontece: laminar quando causada por escoamento difuso das águas das chuvas, resultando na remoção progressiva dos horizontes superficiais do solo e linear quando causada por concentração das linhas de fluxo das águas de escoamento superficial, resultando em incisões na superfície do terreno (na forma de sulcos, ravinas e voçorocas). Dentre estes, as voçorocas são as mais preocupantes e o estágio mais avançado.

A erosão em sulco se apresenta como pequenas incisões na superfície terrestre em forma de filetes muito rasos. Representam áreas em que a erosão laminar é mais intensa (Canil et al. 1995). Apresentam uma profundidade e largura inferior a 50 centímetros, sendo que suas bordas possuem ruptura na superfície do terreno (DAEE, 1990) (Figura 2.2).

Segundo Morgam (1986), o termo sulco é utilizado quando se pode recuperar área degradada pela erosão por operações normais de preparo do solo. Geralmente, a erosão em sulco apresenta-se associada a trilhas de gado e em locais de solo exposto devido à movimentação de terra. 


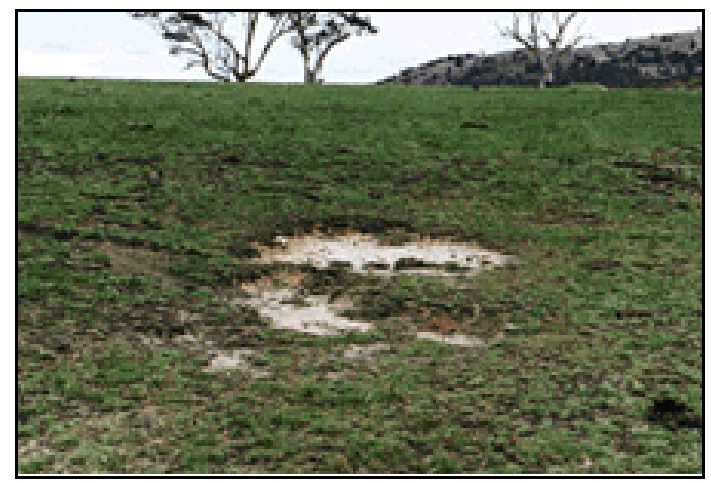

Figura 2.2: Vista geral de feições erosivas do tipo Sulco

Fonte:

http://www.netc.net.au/enviro/f guide/sheeterosion.html

A erosão em Ravina é formada essencialmente pelo escoamento de água superficial, que provoca o desprendimento de partículas do solo e movimento de massa devido ao abatimento dos taludes com forma retilínea, alongada, estreita e profundidade acima de 0,5m. Estas raramente se ramificam, e não chega a atingir o nível freático, sendo que seu perfil transversal apresenta-se em " $V$ ", e geralmente, ocorre entre eixos de drenagens" (Canil et al, 1995) (Figura 2.3).

De acordo com Guerra \& Cunha (1995) as ravinas são formadas quando a velocidade do fluxo de água aumenta na encosta, quase sempre, iniciadas a uma distância crítica do topo desta, onde o escoamento superficial se torna canalizado, podendo ser formadas próximo à base, onde uma pequena incisão recua em direção ao topo.

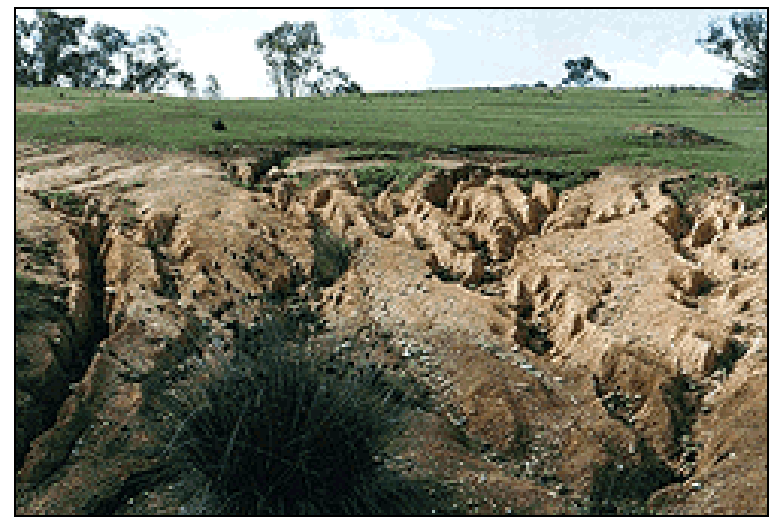

Figura 2.3: Vista geral de feições erosivas do tipo Ravina

Fonte:

http://www.netc.net.au/enviro/fquide/g ullero.html

\section{A erosão em Voçorocas (Erosão Acelerada)}

O termo Voçoroca ou Boçoroca deriva do tupi-guarani (ibi-çorok) e corresponde a expressão terra rasgada (Herrmann et al., 1994). Segundo Guerra (1972), o termo voçoroca é o mais adotado, apesar da grande discussão até os dias atuais sobre a terminologia correta. As traduções adotadas no Brasil para este termo são: inglês-gully e francêsRavine, segundo o glossário geológico (Viktor Leinz \& Leonardos, 1971).

Segundo (Morgam, 1996) as voçorocas são cursos de água relativamente permanente com paredes altas, que conduzem pequenos fluxos durante as chuvas. Comparadas com 
cursos de drenagem de rios estáveis, que são relativamente planos e côncavos ao longo de todo seu perfil. As voçorocas se caracterizam por ter uma cabeceira e diferentes ressaltos ao longo de seu curso. Estas são consideradas como erosão acelerada, por tanto, são consideradas formas de paisagens instáveis (Figura 2.4). Corresponde à passagem gradual do processo de ravinamento, até atingir o lençol freático, com o aparecimento de surgências d'água.

Dentre estes conceitos destacam-se aqueles relacionados à geometria e dimensões $e$ os relativos aos mecanismos. Quanto à dimensão Lal (1990) considera voçoroca as feições erosivas que não podem ser controladas através de manejo por maquina agrícolas comum. Quanto a largura Kronen (1990) considera maior que $3 \mathrm{~m}$, enquanto Fendrichi (1997) considera profundidades superiores a $1 \mathrm{~m}$ e área drenante superiores 2 ha; e quanto aos mecanismos a SSSA( Soil Science Society of América, 2001) define que é o processo onde a água do escoamento acumulado flui repetidas vezes no mesmo canal removendo o solo até profundidades consideráveis, variando da ordem de metro a dezenas de metros.

Brice (1966) classificou 3 tipos de voçorocas: de cabeceira, de fundo de vale e de encosta. Predominantemente ocorrem as de cabeceira e de encostas, estas também foram descritas por Morgan (1996).

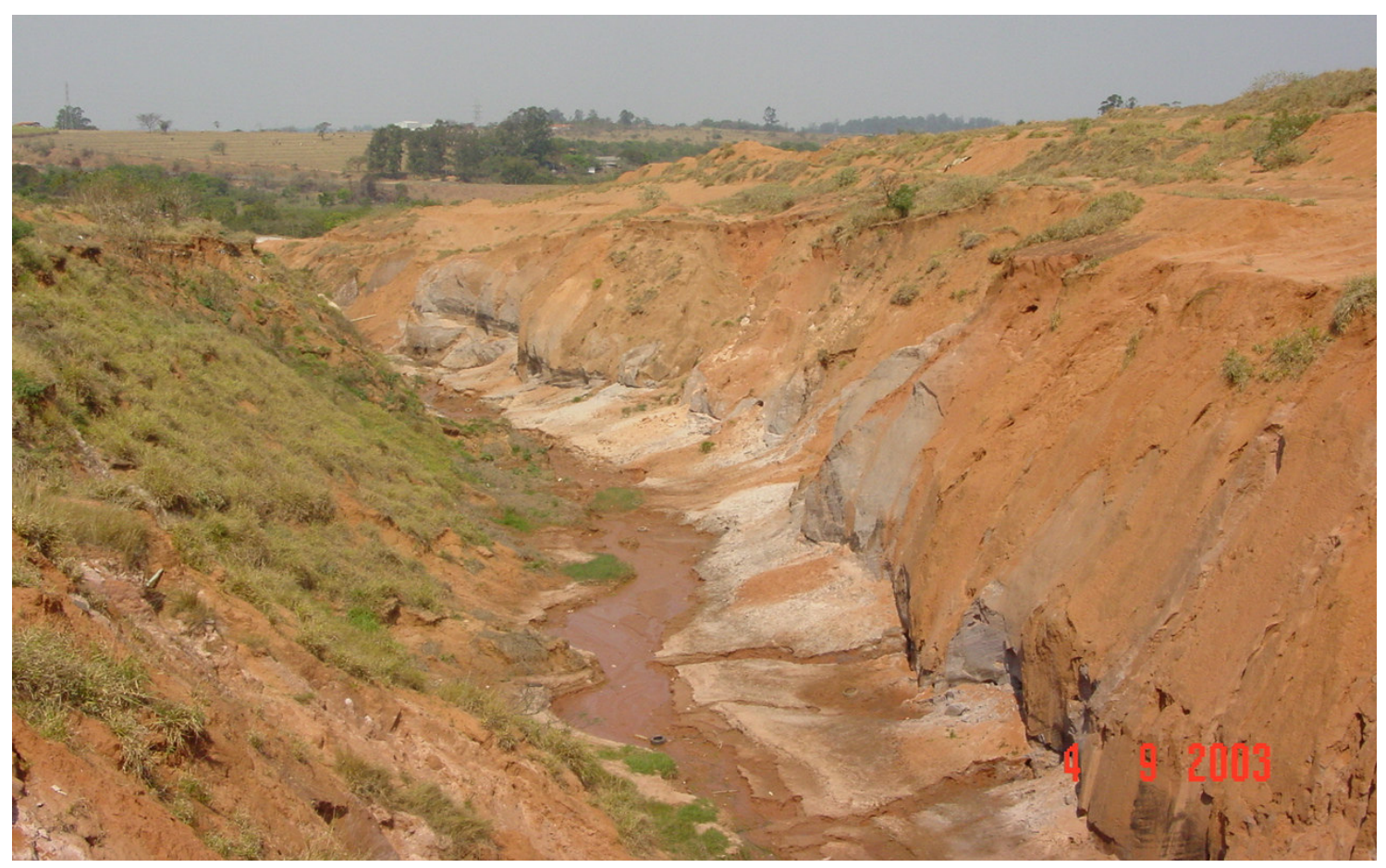

Figura 2.4: Voçoroca localizada no município de São Pedro (SP) 


\section{A erosão em piping}

Quando os vazios criados no interior do solo pelo "piping" tornam-se significativos, podem dar origem a colapsos do terreno, com desabamento que alargam as voçorocas ou criam novos ramos. Associam-se também aos processos de erosão interna os deslocamentos e solapamento da base das paredes das voçorocas, que provocam desmoronamento ou escorregamento de solos (DAEE, 1990).

De acordo com este mesmo autor a ação das águas subterrâneas é apontada como uma das causas do desenvolvimento lateral, onde os mecanismos de erosão são intensificados, em função do surgimento de um gradiente piezométrico que ao emergir no pé do talude apresenta suficiente força para deslocar partículas sólidas, podendo estabelecer o processo de erosão tubular regressiva "piping". Ocorre também a liquefação do material arenoso pela lenta percolação d'água junto a parede da voçoroca, ocorrendo uma diminuição da coesão do solo e conseqüentemente solapamento do talude.

\section{4- ZONA DE OCORRÊNCIA}

As feições erosivas são classificadas também pelo local em que ocorrem em: Erosão Urbana e Rural. A seguir será descrita em maior detalhe a erosão urbana por tratar-se do foco principal deste estudo.

\subsection{1.- EROSÃO URBANA}

Segundo Iwasa \& Pranini (1980) as voçorocas urbanas se constituem em fenômenos erosivos que envolvem áreas consideráveis, mobilizando grandes volumes de solo. Este fenômeno se faz sentir de modo mais danoso por duas razões: o caráter catastrófico inerente ás áreas envolvidas e o próprio processo de urbanização que interfere de modo drástico no meio físico, apresentam-se então como feições rápida evolução e de difícil controle.

Segundo Ridente e Almeida Filho (1998) na origem, a erosão urbana está associada á falta de planejamento adequado, que considere as particularidades do meio físico, as condições socioeconômicas $e$ as tendências de desenvolvimento da área urbana. Este desenvolvimento amplia as áreas construídas e pavimentadas aumentando substancialmente - volume e a velocidade das enxurradas $e$, desde que não dissipadas, concentra os escoamentos, acelerando os processos de desenvolvimento de ravinas e voçorocas, com perdas significativas para a população e o poder público local. Pode-se considerar que já foi 
alcançada uma boa experiência nas medidas corretivas que vem sendo implantadas no sulsudeste brasileiro e, em particular, no estado do Paraná.

A erosão urbana é extremamente dinâmica com grande variabilidade temporal $e$ espacial, acompanhado o processo de consolidação da ocupação. Estando associada, em causa e efeitos, aos problemas de drenagem urbana, a erosão urbana deve ser considerada como uma variável de projeto de particular importância, merecendo cuidados de tratamento não só nas fontes principais de produção de sedimentos, como também ao longo de todos os percursos do sistema de drenagem, para evitar acidentes que produzam erosões localizadas de grande envergadura.

A urbanização, como toda obra que interpõe estruturas pouco permeáveis entre o solo e a chuva, provoca um aumento do escoamento devido à diminuição da infiltração, numa mudança de regime de escoamento localmente mais drástica, do que aquela provocada pelo desmatamento. Assim, provoca a concentração das águas pluviais em cabeceiras de drenagens desencadeando a formação de processos erosivos nas próprias vias, que constituem os principais condutos das águas captadas pelos telhados das edificações, somadas ao escoamento superficial local (Almeida filho, 1998).

Os principais fatores que influenciam na erosão das áreas urbanas estão relacionados com o escoamento superficial (Pontes, 1980) são: vazão da corrente de água, declividade do terreno e a natureza do terreno.

\subsection{2- IMPACTOS DECORRENTES DA EROSÃO URBANA}

$O$ atual quadro de degradação dos solos é significativa e preocupante, em consequiência do manejo inadequado destes ou da implantação de obras de engenharia e saneamento sem os devidos cuidados necessários. Uma grande parte dos municípios do Brasil já apresenta problemas de degradação dos solos, tanto em áreas agrícola como em áreas urbanas, podendo ser considerado como um dos mais importantes problemas ambientais dos nossos dias (Carvalho, 2001).

Segundo Coelho Neto (1998), a intensidade do processo erosivo pode ultrapassar valores críticos, ou seja, acima da capacidade do sistema ambiental de absorver os efeitos instantâneos e futuros, tornando-se assim um problema à preservação ambiental e de conservação da qualidade de vida humana. Pode-se caracterizado como um fenômeno de Risco Ambiental, que pode solidificar-se como uma barreira no caminho do desenvolvimento sustentável em áreas urbanas. Ainda segundo este autor muitos destes problemas citados 
acima estão associados à fatores antrópicos, como o desenvolvimento urbano que quebra bruscamente a estabilidade do ecossistema, com atividades como: desmatamento para processo de ocupação, construção de obras civis reduzindo a infiltração das águas no solo $e$, conseqüentemente, aumentando o escoamento superficial.

De acordo com (Ridente, 2001), o grande prejuízo atual do processo erosivo em áreas urbanas é de caráter social e econômico, pois a deflagração ou evolução deste leva à destruição de moradias e equipamentos públicos, como ruas, sistemas de esgoto, redes elétricas, sistemas de drenagem, além de poder levar à perda de vidas humanas. Se este processo erosivo for de grande porte, o dano ambiental também pode ser calculado com base na degradação do solo local e da difícil recuperação da área, que envolve uma grande movimentação de terra associada à construção de sistemas de drenagem superficial e subterrâneo (Macro e Microdrenagem). A magnitude deste processo quando instalado em áreas de expansão urbana e fator importante a ser levado em conta, pois quanto maior a amplitude da feição erosiva no local, maior é a barreira ao avanço da urbanização nesta direção, causando uma grande desvalorização do patrimônio imobiliário e alto custo de projeto de urbanização do local.

Para Almeida Filho (1998), o desenvolvimento das voçorocas nas áreas urbanas provoca algumas consequiências ao meio ambiente como pode ser visto na Tabela 2.3. Além dos impactos sociais e econômicos, devido o desencadeamento destas feições atingirem imóveis e infra-estrutura representadas por: obras de redes de água, esgoto, telefone, eletricidade, drenagem pluvial e pavimentação, este autor cita ainda como consequiências indiretas a paralisação do tráfego e depreciação imobiliária. Além de todos estes problemas a erosão é um fator limitante da expansão urbana, em função dos altos custos de correção, desenvolvimento de focos de doenças (pela prática comum de aterro com lixo urbano e despejo de esgoto) e assoreamento de galerias e fundos de vale (acarretando graves problemas de inundações e perda da capacidade de armazenamento d'água dos reservatórios de abastecimento público). 
Tabela 2.3: Impactos ambientais da ocupação sobre o meio físico (modificada de Chiossi, 1983) apud Almeida Filho (1998).

\begin{tabular}{|c|c|c|c|c|}
\hline \multirow{5}{*}{ URBANA } & OCUPAÇÃO & INTERVENÇÃO & IMPACTOS & CONSEQUÊNCIAS \\
\hline & Loteamento & $\begin{array}{l}\text { Remoção da cobertura vegetal } \\
\text { e Terraplenagem; cortes e } \\
\text { aterros; }\end{array}$ & $\begin{array}{l}\text { Erosão; } \\
\text { Modificação } \\
\text { paisagem }\end{array}$ & $\begin{array}{l}\text { Assoreamento; } \\
\text { Inundação/Enchentes }\end{array}$ \\
\hline & Área industrial & $\begin{array}{l}\text { Remoção da cobertura vegetal } \\
\text { e Terraplenagem; cortes e } \\
\text { aterros; }\end{array}$ & $\begin{array}{l}\text { Erosão localizada, } \\
\text { poluição do ar, solo e } \\
\text { água }\end{array}$ & $\begin{array}{c}\text { Assoreamento } \\
\text { Contaminação do ar solo e água }\end{array}$ \\
\hline & Sistema Viário & $\begin{array}{l}\text { Desmatamento; } \\
\text { Terraplenagem; cortes e } \\
\text { aterros; } \\
\text { Sistema de drenagem }\end{array}$ & $\begin{array}{l}\text { Erosão; } \\
\text { Escorregamento }\end{array}$ & Assoreamento \\
\hline & $\begin{array}{c}\text { Infra-estrutura } \\
\text { urbana }\end{array}$ & $\begin{array}{l}\text { Escavações; } \\
\text { Sistema de drenagem; } \\
\text { Terraplenagem; cortes e } \\
\text { aterros; }\end{array}$ & $\begin{array}{l}\text { Erosão; } \\
\text { Escorregamento }\end{array}$ & $\begin{array}{c}\text { Assoreamento; } \\
\text { Inundações/Enchentes }\end{array}$ \\
\hline
\end{tabular}

A existência de processos de erosão linear dentro das áreas urbanas, principalmente voçorocas, torna mais crítica a gestão urbana. Principalmente quando são feições são de grande portes e passam a interferir diretamente na vida dos habitantes, com por exemplo: na interrupção de acessos, destruição de sistemas de abastecimento, esgoto, etc. As voçorocas causadas principalmente pela expansão urbana, também tornamse uma barreira ao crescimento da própria cidade, devido ao risco que oferecem à população, dificultando até mesmo a ocupação nas áreas vizinhas e o planejamento urbano. Devido à complexidade das obras, a recuperação de áreas degradadas pela erosão é onerosa, necessitando muitas vezes de verbas externas ao orçamento municipal (Ridente et al., 1998b).

Segundo Vedovello et al.(1998) dentre os diversos critérios geo-ambientais a serem considerados para seleção, por exemplo, de áreas para deposição de resíduos sólidos, a determinação da susceptibilidade dos terrenos á ocorrência de processos erosivos (sulcos, ravinas e voçorocas), é muito importante e decisivo para a escolha de locais apropriados. Esta análise visa à manutenção da qualidade ambiental e a segurança das próprias obras a serem implantadas. Quando estas feições são utilizadas como área de deposição de resíduos pode ocasionar vários problemas como: formação de catadores de lixo; transforma essas áreas inadequadas para construção, retomada de processo erosivo em maior intensidade, observa-se chorume e possível contamina o solo e os recursos hídricos. 


\section{5- EVOLUÇÃO DAS VOÇOROCAS}

Diversos autores (Pouquet, 1951, Pichler, 1953; Morgan, 1996; Higgins at al., 1990, Vandaele et al., 1996 e Poesen et al., 2003) consideram que as voçorocas apresentam os seguintes estágios de evolução:

$1^{\circ}$ Estágio Inicial: formam-se pequenos sulcos ou reentrâncias nas encostas, devido a diversos fatores associados tais como: forma da encosta, características dos materiais geológicos, escoamento superficial, índice pluviométrico e uso e ocupação. O resultado é a formação de um canal principal definido e de uma escarpa de cabeceira, onde se desenvolvem fluxos críticos acelerando o processo erosivo. Nesta fase os vales são predominantes em $V$ e o talvegue do canal normalmente apresenta diversos degraus (Figura 2.5).

Planta
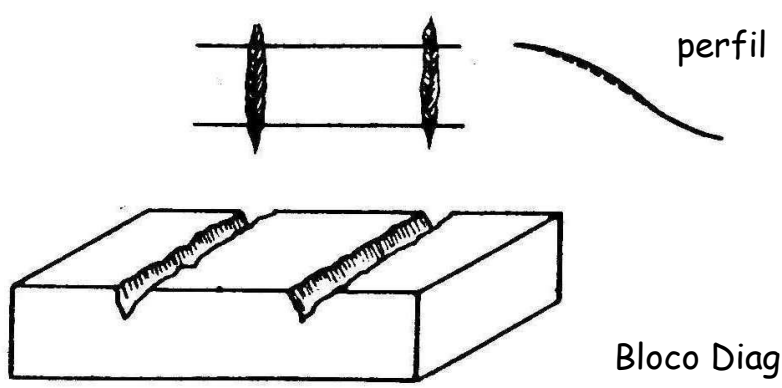

Bloco Diagrama

Figura 2.5: Estágio inicial da evolução de feições erosivas (Fiore \& Soares, 1976).

$2^{\circ}$ Estágio Intermediário: nesta fase ocorre progressão acelerada da cabeceira da feição através do aprofundamento do canal e progressão para montante e lateral; ocasionada por processos de erosão gerada por escoamento sub-superficial (piping) e instabilidade das paredes. Nesta fase os canais passam a ter uma base larga $e$ o talvegue do canal apresenta-se mais contínuo (menor número de degraus) como pode-se observar na Figura 2.6.

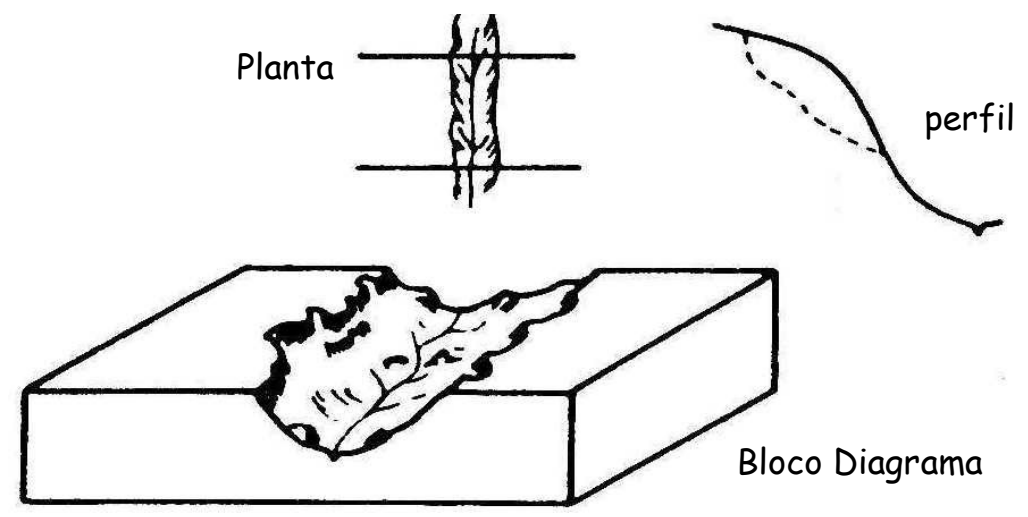

Figura 2.6: Estágio intermediário da evolução de feições erosivas (Fiore \& Soares, 1976). 
$3^{\circ}$ Estágio Maduro: Nesta fase não ocorre mais aprofundamento, apresentam normalmente a forma em $U$, não há um número significativo de degraus e a progressão predominante é lateral, devido a estes fatos continuam ocorrendo deslizamento das paredes e fenômenos do tipo "piping". Em muitos casos as voçorocas apresentam largura maior que a altura nesta fase (Figura 2.7). A partir de um determinado ponto a feição erosiva torna-se uma feição estável de relevo. De acordo com Picher (1953) podem ser consideradas inativas.
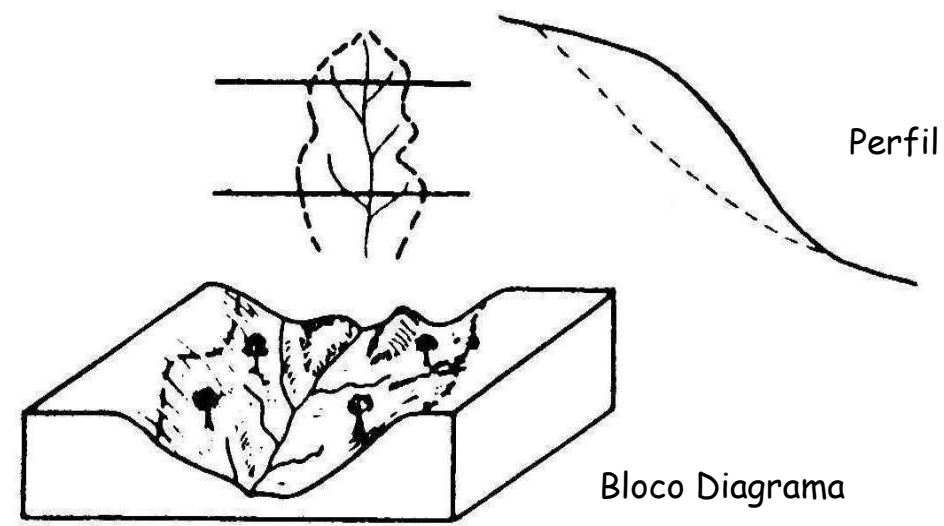

Figura 2.7: Estágio final ou maduro da evolução de feições erosivas (Fiore \& Soares, 1976).

As voçorocas ao contrário das erosões laminares e lineares (do tipo sulco e ravina) apresentam maior grau de dificuldade para utilização de procedimentos padronizados para definição de suas medidas e estudos dos fatores controladores.

Poesen et al. (2003) sugerem um grupo de técnicas laboratoriais e de campo para estudo de voçorocas em diferentes escala de tempo, descritas a seguir:

Para voçorocas com menos de 10 anos: devem ser adotados procedimentos de campo (levantamento topográfico, medidas de dimensão das feições, uso de fotografias terrestres, medidas das taxas de sedimentação, colocação de pinos e monitoração da morfologia das feições) e de sobrevôo (vôo de baixa altitude e regulares).

Para voçorocas de 10 a 70 anos: tem sido utilizadas fotografias aéreas de diferentes períodos, métodos dendrocronológicos, sequiência de desenvolvimento de vegetação, ensaios de erodibilidade e caracterização geotécnica.

Para voçorocas com idade superior a 70 anos: para estes casos tem sido utilizados dados históricos, documentos pré-existentes e várias técnicas de datação dos depósitos decorrentes do processo erosivo. 


\section{6- DEGRADAÇÃO POR PROCESSOS EROSIVOS}

\subsection{1- aspectos gerais}

De acordo com ABNT (1989), a degradação do solo é a alteração adversa das características do solo em relação aos seus diversos usos possíveis, tanto os estabelecidos em planejamento quanto os potenciais. A distinção entre alguns termos relativos a continuidade de uso de áreas degradas são descritos também por essa norma, como:

a) Restauração ("restoration"): associada á idéia de reprodução das condições exatas do local, tais como eram antes de serem alteradas pela intervenção;

b) Recuperação ("reclamation"): associada á idéia de que o local aterrado seja trabalhado de modo a que as condições ambientais acabem-se situando próximas às condições anteriores a intervenção; ou seja, trata-se de devolver ao local o equilíbrio e a estabilidade dos processos ambientais ali atuantes anteriormente;

c) Reabilitação ("reabilitation"): associada á idéia de que o local alteado deverá ser destinado a uma dada forma de uso do solo, de acordo com o projeto prévio e em condições compatíveis com a ocupação circunvizinha, ou seja, trata-se de reaproveitar a área para outra finalidade.

Segundo Nunshower (1994) apud Franchi (2000), os termos acima citados podem ser assim também definidos:

a) Recuperação: é tornar um sitio degradado novamente aproveitável para uma determinada função, ou seja, a reconstituição topográfica do solo e da comunidade de plantas não será igual á condição original prédegradada.

b) Restauração: consiste no retorno de um sitio degradado a condição original, ou seja, é a reconstituição do ecossistema, com sua forma e funções originais:

c) Reabilitação: ocorre sem a intervenção do homem quando é fornecido tempo suficiente para que as mudanças edáficas e biológicas ocorram. Revegetação ("revegetation"): é o componente final e o mais visível no plano de recuperação.

Analisando os conceitos acima pode-se concluir que as duas definições não são completas. A primeira reflete o processo de forma muito generalizada, não suficiente, portanto para definir bem uma área que sofreu degradação. Já a segunda mostra-se voltada muito mais para aspectos vegetativos. 


\subsection{2- CUSTOS DA RECUPERAÇÃO DE ÁREAS DEGRADADAS POR PROCESSOS EROSIVOS}

As soluções para recuperar e controlar processos erosivos, por vezes se tornam trabalhosas, tendo em vista que quanto maior a intensidade do fenômeno mais complexa e cara será a técnica necessária. Porque as medidas necessárias, que normalmente deveriam ser adotadas, acabam não sendo concretizadas por dificuldades enfrentadas pelos órgãos responsáveis em nível municipal, estadual e federal, sob alegação de falta de verba ou pela falta de consciência na necessidade de prevenção a erosão (Rodrigues, 1995).

As perdas de terrenos urbanos e impactos negativos gerados pela da erosão dos solos fazem parte do custo econômico e social da degradação ambiental. Mas estes custos são muitas vezes negligenciados pelos próprios proprietários e pelo poder público. Isso ocorre geralmente pela falta de conhecimento sobre as consequiencias deste tipo de degradação do solo, pelo fato que essas são indiretas ou difusas, e perceptíveis somente em longos períodos de tempo. A determinação dos custos da erosão do solo aparece, neste contexto, como uma importante ferramenta para conscientização quanto à necessidade de investimentos, voltados a sua conservação (Seroa, 1997).

Segundo Souza (2001), o sucesso de um projeto técnico bem gerenciado depende da disponibilidade de recursos financeiros para sua implantação, que envolve, por exemplo, desde coleta das informações básicas do meio físico até a execução de uma obra de controle. Claro que, isso não significa que as técnicas, mais caras são as mais adequadas ou vice-versa. Nesse contexto, deve-se proceder a um estudo detalhado da obra, considerando-se as áreas afins envolvidas (administradores de empresa, economistas, engenheiros civis, agrônomos, geólogos, etc.).

A relação custo-benefício vem sendo muito discutida em vários países por muitos autores, em pesquisas relacionadas ao meio físico, desde a década de trinta. Para Santos (1981), é necessário que exista da parte governamental uma programação financeira ajustada com a parte técnica, para que não haja descontinuidade liberação de recursos, pois, na problemática da erosão, quando uma etapa no controle de feições erosivas não é totalmente concluída, há o grande risco de se perderem as obras executadas. $O$ autor sugere ainda a imposição de uma rigorosa política do uso do solo, aliada a uma segura orientação na execução de planos diretores, visando à prevenção dos processos erosivos. 
Assim, o levantamento das informações do meio físico deverá ser executado por meio de técnicas e métodos que sejam simples, baratos e objetivos (Zuquette, 1987). No entanto, na ausência de subsídios públicos, muitas medidas de conservação do solo tornamse onerosas. As práticas conservacionistas muitas vezes proporcionam um benefício em longo prazo em troca de custos imediatos (Bertoni \& Lombardi Neto, 1999).

De acordo com Albrechet (1998) algumas questões devem ser consideradas durante a avaliação de custos, tais como: custos relacionados aos trabalhos realizados e aos tipos de tratamento segundo a finalidade de uso, as medidas de monitoramento, as medidas mitigadoras, que devem incluir todas as outras obras de infra-estrutura vinculadas à finalidade de uso pretendida.

Winpenny (1991), propôs três procedimentos a serem tomados, dependendo da situação a ser analisada em questão:

análise de custo e benefícios: Combina o rigor com a generalidade, focalizando o balanço entre os custos e os benefícios de uma ação. Geralmente, analisa as situações em que os custos do desenvolvimento devem ser definidos, considerando os recursos necessários para o desenvolvimento e as implicações nas mudanças ambientais:

avaliação de custo e eficiência: Objetiva selecionar qual a melhor opção para atingir as metas com o menor custo total. É uma técnica útil de ser aplicada quando os benefícios não podem ser mensurados. Por exemplo, na escolha do procedimento mas eficiente para se atingir determinados objetivos ambientais, onde é preciso determinar o melhor uso de um orçamento disponível e o procedimento adequado para decidir qual meta deva ser adotada;

avaliação dos benefícios ambientais: É realizada objetivando abranger três determinados grupos de indivíduos que serão beneficiados. O primeiro tipo é formado por indivíduos que fazem e estabelecem o valor do uso real $e$ das potencialidades ambientais (poluidores, agricultores, etc.). A segunda categoria de usuários representa o valor de opção das potencialidades ambientais no futuro, ou seja, podem estar presentes ou ainda não serem integrantes da população atual.

Porto \& Azevedo (1997) analisam que a proposta benefício-custo (Tabela 2.4) tão aplicada em projetos de análises ambientais em vários países, não foi uma metodologia bem 
sucedida, devido ao fato de que poucas decisões foram efetivamente tomadas com base apenas nesses critérios. Ou seja, alguns fatores de ordem prática (a dificuldade de obtenção de dados para quantificar benefícios-custo pode tornar os resultados pouco confiáveis e/ou manipuláveis) e outros de ordem teórica (a relação benefício-custo pode ter significados diferentes para os diversos grupos de interesse afetos ao problema) impediram a consagração do método.

Tabela 2.4: Formas de análise, benefício-custo (Porto \& Azevedo, 1997)

\begin{tabular}{|l|l|}
\hline Maximização do Benefício líquido & $\begin{array}{l}\text { Desejava-se o maior benefício líquido possível, ou seja, o maior valor da } \\
\text { diferença entre benefícios e custos. Usualmente este critério conduz a } \\
\text { projetos de porte muito grande, acima dos recursos disponíveis. Neste } \\
\text { caso, é comum procurar-se o maior benefício possível para o nível de } \\
\text { investimento preestabelecido. }\end{array}$ \\
\hline Maximização do benefício por & $\begin{array}{l}\text { Procura-se, neste caso, o maior valor de relação benefício/custo ou, em } \\
\text { outras palavras, prioriza-se a produtividade. É muito comum que projetos } \\
\text { dimensionados com esse critério sejam de pequeno porte, com alcance } \\
\text { muito limitado em termos sociais e econômicos. }\end{array}$ \\
\hline Minimização dos custos & $\begin{array}{l}\text { Procura-se a alternativa que atinja um determinado nível de desempenho } \\
\text { preestabelecido com o mínimo custo. }\end{array}$ \\
\hline
\end{tabular}

A avaliação de custo de obras possui um importante papel na gestão ambiental $e$ urbana. Tendo em vista, que nem sempre o mais caro é melhor, nem que o mais barato significa pouca qualidade. Sendo assim, avaliação das técnicas tem que ser baseada nestes 3 índices: qualidade, resposta do meio e custo.

\section{7- TÉCNICAS DE CONTROLE DE EROSÃO URBANA}

Até os dias atuais o controle da erosão ainda se mostra insatisfatório. Mas esta dificuldade não é devida a uma falta de conhecimento dos processos de erosão em si, para que assim se pudesse controlá-la de forma melhor. Mas isso é na verdade o fruto da dificuldade que encontramos em priorizar dentro de um projeto as características particulares das feições e do ambiente em que estas estão inseridas. Levando assim a uma concepção de etapas dentro de um projeto, que relacionem a melhor técnica, sua viabilidade econômica, mão-de-obra necessária e estação do ano, tomando assim as decisões 
necessárias para a prevenção e um controle satisfatório, sem a destruição das etapas já executadas.

As ravinas e voçorocas já instaladas exigem soluções que possam ser implantadas em larga escala e, portanto, que sejam as mais simples possiveis e as menos onerosas, mas sobretudo, soluções que sejam eficientes e que também justifiquem os investimentos públicos, resultando em segurança para a população e para os seus equipamentos públicos, de forma a devolver a área para o seu uso urbano (DAEE, 1990).

Segundo DAEE (1990), as voçorocas, como extensão de drenagem urbana, recebem atenção da administração pública em termos de obras, ao longo do seu desenvolvimento. Mas a grande maioria destas intervenções é destruída em curto espaço de tempo, como mostra a figura 2.8. Sendo que são muitas as causas verificadas na ruína inesperada das estruturas e obras implantadas para interromper o crescimento de voçorocas. O subdimensionamento das obras em termos de vazão das enxurradas é causa bastante comum.

De acordo com Carvalho et al (2001), no meio geotécnico, as principais obras de controle e recuperação de áreas atingidas por voçorocas compreendem: o disciplinamento do fluxo de água, tanto superficial como sub-superficial através da implantação de sistemas de drenagem, obras de retaludamento, revegetação, obras de contenção de taludes, obras de reaterro e obras de barramento.

Segundo Almeida Filho (1998) a elaboração do projeto de contenção deve levar em conta alternativa que contemplem as seguintes medidas principais: disciplinamento das águas superficiais, disciplinamento das águas subterrâneas, que é uma das principais causas do desenvolvimento lateral e remontante, através de drenos filtrantes impedindo o carreamento do solo "piping", estabilização dos taludes ou recomposição da área por terraplenagem e revegetação, execução de emissários conduzindo as águas nos pontos do talvegue estáveis e conservação das obras. 


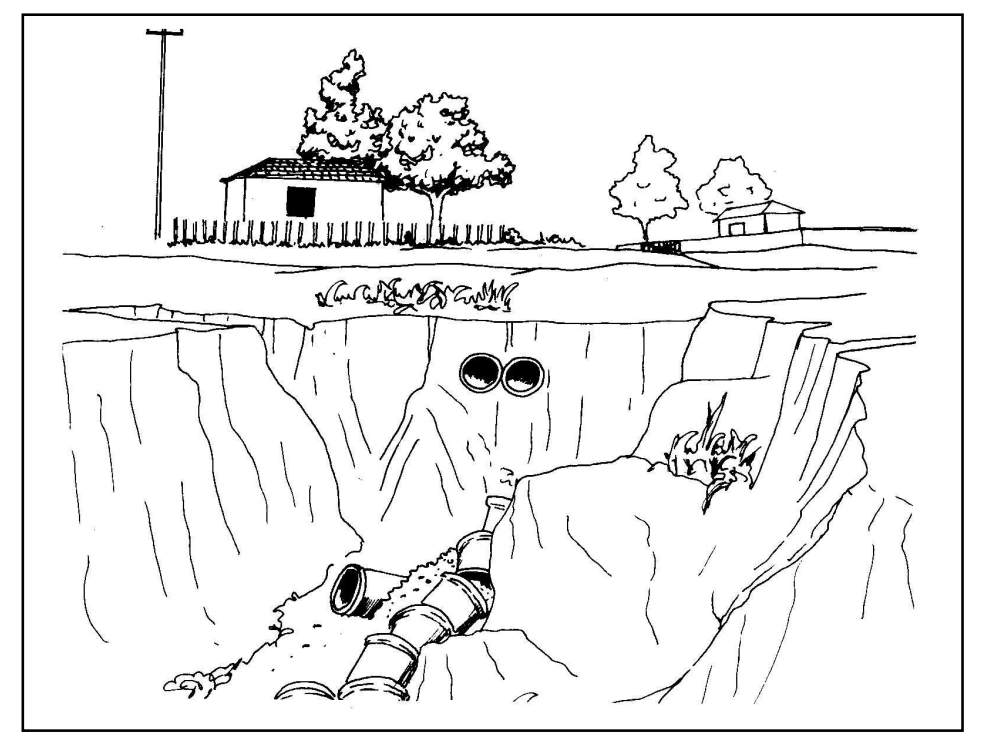

Figura 2.8: Lançamento do sistema de drenagem na meia encosta sem execução de um dissipador de energia (DAEE, 1990).

Segundo Fendrich (1997), não existe uma metodologia única a ser aplicada nesses tipos de obras, mas para cada caso deve ser utilizado um tipo específico, ou seja, elas são determinadas em função das condições de contorno que se apresentam e que são impostas pelo meio físico, objetivos do estudo e recursos disponíveis (Tabela 2.5).

Tabela 2.5- Propostas de práticas de controle de processos erosivos em áreas urbanas, modificado de Souza (2001).

\begin{tabular}{|c|c|c|c|c|c|}
\hline \multirow{2}{*}{\multicolumn{3}{|c|}{ PRÁTICAS DE CONTROLE }} & \multicolumn{3}{|c|}{ MEDIDAS } \\
\hline & & & CORRETIVAS & MITIGADORAS & PREVENTIVAS \\
\hline \multirow{18}{*}{$\begin{array}{l}\frac{0}{3} \\
\frac{3}{4} \\
\frac{0}{0} \\
\frac{0}{5} \\
\frac{0}{d}\end{array}$} & \multirow{11}{*}{ 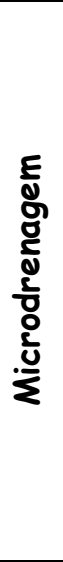 } & Meios fios/ Guias & $x$ & $x$ & $x$ \\
\hline & & Sarjetas & $x$ & $x$ & $x$ \\
\hline & & Sarjetões & $x$ & $x$ & $x$ \\
\hline & & Bocas-de-lobo/ Bocas coletoras & $x$ & $x$ & $x$ \\
\hline & & Galerias & $x$ & $x$ & $x$ \\
\hline & & Poços de visita & $x$ & $x$ & $x$ \\
\hline & & Trecho & $x$ & $x$ & $x$ \\
\hline & & Tubos de ligações & $x$ & $x$ & $x$ \\
\hline & & Caixas- de- ligação & $x$ & $x$ & $x$ \\
\hline & & Estações de bombeamento & $x$ & & \\
\hline & & Coletores & $x$ & $x$ & $x$ \\
\hline & \multirow{7}{*}{ 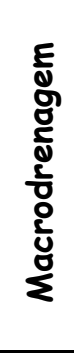 } & Canais: naturais ou artificiais & $x$ & $x$ & $x$ \\
\hline & & Dissipadores de energias & $x$ & $x$ & $x$ \\
\hline & & Ressalto hidraúlico & $x$ & $x$ & \\
\hline & & Barragens & $x$ & $x$ & \\
\hline & & Vertedouros & $x$ & $x$ & \\
\hline & & Bacia de acumulação & $x$ & $x$ & \\
\hline & & Bacias dissipadoras & $x$ & $x$ & \\
\hline
\end{tabular}




\begin{tabular}{|c|c|c|c|c|}
\hline \multirow{5}{*}{$\begin{array}{ll}y & y \\
0 & 0 \\
+ & 0 \\
0 & 0\end{array}$} & Contenção e Proteção de taludes & $x$ & $x$ & $x$ \\
\hline & Revegetação & $x$ & $x$ & $x$ \\
\hline & Aterramento & $x$ & $x$ & \\
\hline & Barramento & $x$ & $x$ & \\
\hline & Terraceamento & $x$ & $x$ & \\
\hline \multirow{6}{*}{ 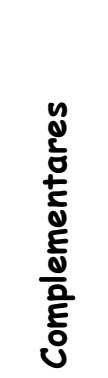 } & Obras de pavimentação & $x$ & $x$ & $x$ \\
\hline & Drenos & $x$ & $x$ & \\
\hline & Geossintéticos & $x$ & $x$ & \\
\hline & Gabião & $x$ & $x$ & $x$ \\
\hline & Obras auxiliares de proteção & $x$ & $x$ & \\
\hline & $\begin{array}{l}\text { Mapeamento/ Cartografia } \\
\text { geotécnica }\end{array}$ & & & $x$ \\
\hline 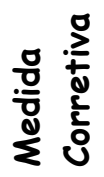 & Lixo & $x$ & & \\
\hline
\end{tabular}

\subsection{1- OBRAS DE DISCIPLINAMENTO DO FLUXO DE ÁGUA}

O controle das erosões consiste na execução de um conjunto de obras, cuja finalidade principal é evitar ou diminuir a energia do escoamento das águas pluviais sobre terrenos desprotegidos e susceptíveis, que pode ser conseguido com obras de sistema de drenagem tais como: pavimentação das ruas, execução de guias, sarjetas, boca de lobos e galerias de águas pluviais, como pode ser visto na figura 2.9.

Os métodos preventivos envolvem um trabalho de reconhecimento das características no meio físico, uso e direcionamento das formas de ocupação. Já os métodos de controle abrangem a análise da situação atual da feição erosiva $e$ a concepção de um projeto hidráulico e estrutural para solucionar o problema (Galerini in Bidone \& Tucci,1995).

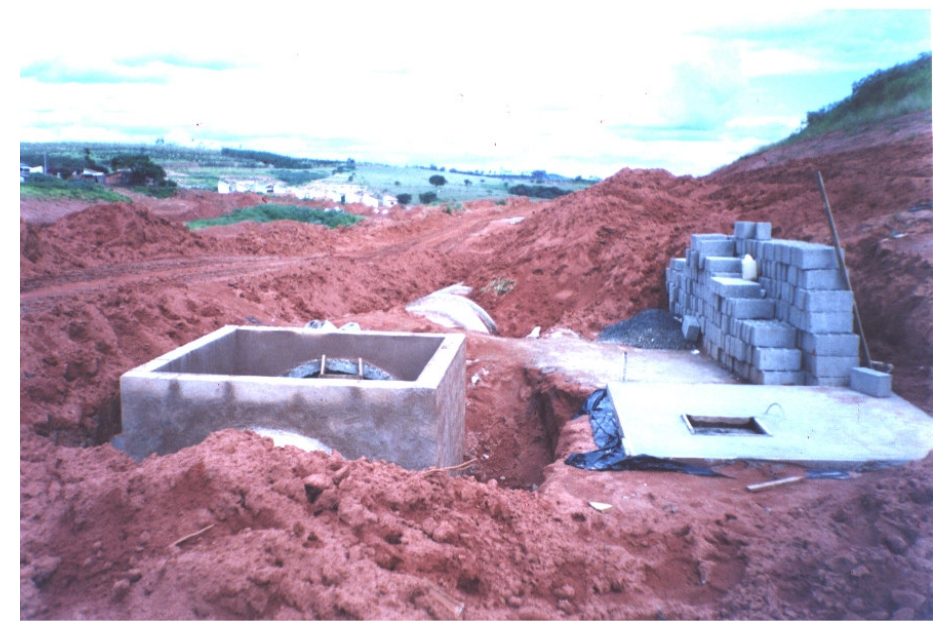

Figura 2.9: Execução de obras de disciplinarmente do fluxo para contenção de voçoroca de São Pedro/SP 
No controle das erosões é fundamental a realização de um diagnóstico do processo (determinando a área de drenagem e o hidrograma de contribuição). Segundo diversos autores como Bidone \& Tucci (1995) e Fendrich (1997) podem ser utilizadas como métodos de controle de erosão urbana: a macrodrenagem e a microdrenagem

\subsubsection{1- MICRODRENAGEM}

Este tipo de obra tem como objetivo esgotar as vazões oriundas das chuvas mais freqüentes. Possuem um papel importante no controle dos processos erosivos, pois impedem o escoamento direto sobre o solo. As águas que escoam superficialmente pelas ruas ou superfície do terreno são captadas por caneletas chamadas sarjetas, que possuem dimensões e inclinações padronizadas, sendo que sua forma varia de acordo com a inclinação da rua e o volume da água escoada. As sarjetas conduzem a água até as bocas de lobo, a água captada pelas bocas-de-lobo e drenagem pluvial é conduzida à tubulação (devido à velocidade das águas no final da tubulação e para evitar a erosão, são utilizados dissipadores de energia). Estas conduzem às saídas que são remanejadas até as galerias ou a canais abertos.

As águas superficiais provenientes de chuva $e$ esgoto devem ser captadas $e$ conduzidas desde a cabeceira da voçoroca até um local adequado para a descarga, onde a sua energia possa ser dissipada. Sendo assim na concepção de projeto deve-se ter como preocupação básica à diminuição da energia das águas captadas e a sua condução controlada, dentro e fora da voçoroca (DAEE, 1990).

Os principais elementos da microdrenagem que estão descritos a seguir, tem como base os trabalhos de: Tucci (2001); Bidone e Tucci (1995); Ridente \& Almeida Filho (1998) e Fendrich (1997) e DAEE (1990).

1. Meio- Fio (guias): elementos de pedra ou concreto, colocado entre o passeio e a via pública, paralelamente ao eixo da rua e com sua face superior no mesmo nível do passeio:

2. Sarjetas: faixa de via pública, paralelas e vizinhas ao meio-fio. A calha formada é a receptora das águas pluviais que incidem sobre as vias publicas e que para elas escoam; 
3. Sarjetões: calhas localizadas nos cruzamento de vias públicas, formadas pela sua própria pavimentação e destinadas a orientar o fluxo das águas que escoam pelas sarjetas:

4. Bocas-de-lobo /Bocas Coletoras: dispositivos localizados em pontos convenientes, nas sarjetas, para captação de águas pluviais. Podem ser implantadas na guia, com grelhas paralelas ao eixo da rua, na forma combinada (guia e grelha) e com fendas horizontal e longitudinal na forma combinada. São geralmente utilizadas sozinhas, mas podem também ser empregadas de forma múltipla (com ou sem depressão). Essas variações dependerão do projeto da rua a ser implantado:

5. Galerias: canalização usada para conduzir as águas pluviais provenientes das bocas de lobo e das ligações privadas. Elas devem ser projetadas para funcionamento a seção plena com a vazão de projeto, e a velocidade máxima admissível é determinada em função do material a ser empregado na rede. Por exemplo, para tubo de concreto, a velocidade máxima admissivel é de $5,0 \mathrm{~m} / \mathrm{s}$ e $0,60 \mathrm{~m} / \mathrm{s}$ a velocidade mínima;

6. Poços de visita: dispositivo localizado em pontos convenientes do sistema de galerias para permitir mudanças de direção, declividade, diâmetro, inspeção e limpeza das canalizações:

7. Trecho: porções de galeria situada entre dois poços de visita;

8. Tubos de ligação: canalizações destinadas a conduzir as águas pluviais captadas nas bocas- de lobo para galerias ou para os poços de visita.

9. Caixas-de-ligação: são utilizadas quando se faz necessário a locação de bocas-de-lobo intermediarias ou para evitar-se a chegada, em um mesmo poço de visita, de mais de quatro tubulações. Sua função é similar à do poço de visita, dele diferenciam-se por não serem visitáveis:

10. Estações de bombeamento: conjunto de obras equipamentos destinados a retirar água de um canal de drenagem, quando não mais houver condição de escoamento por gravidade, para um outro canal em nível mais elevado ou receptor final da drenagem em estudo:

11. Coletores: A locação da rede coletora de águas pluviais geralmente é feita de duas maneiras: sob o meio-fio ou sob o eixo da via publica. 0 recobrimento mínimo deve ser de $1,0 \mathrm{~m}$ sobre a geratriz do tubo, 
possibilitando também a ligação das canalizações de escoamento com recobrimento mínimo de $0,60 \mathrm{~m}$ das bocas-de-lobo.

\subsubsection{2- MACRODRENAGEM}

As estruturas de macrodrenagem destinam-se a condução final das águas captadas pela drenagem primária, dando prosseguimento ao escoamento dos deflúvios oriundos das ruas, sarjetas, vales e galerias, que são elementos anteriormente englobados como estruturas de microdrenagem. De fato, a macrodrenagem de uma zona urbana corresponde á rede de drenagem natural pré-existente nos terrenos antes da ocupação, sendo constituída pelos córregos, riachos e rios localizados nos talvegues e vales (Martins, 1995 ).

Martins (1995) enfatiza a necessidade de execução de um projeto bem dimensionado para esse tipo de obras, que envolve principalmente; cálculo adequado da vazão, diretriz geométrica bem elaborada (volume de corte e aterro, cotas de seções em relação à área drenada e aos projetos urbanísticos) e desempenho dos impactos ambientais que são gerados nas instalações das obras.

Tucci \& Genz (1995) dizem que o controle de vazões na macrodrenagem urbana pode ser realizado por medidas estruturais ou não estruturais. As medidas estruturais são aquelas que modificam o rio, evitando prejuízos decorrentes das inundações. Por exemplo, canalização, reservatório de amortecimento, diques, etc. As medidas não-estruturais são aquelas que possibilitam que os prejuízos sejam reduzidos pela melhor convivência da população com as enchentes. Por exemplo, o zoneamento de áreas de inundações através de regulamento do uso do solo com risco de inundação, ocupação com áreas de lazer, seguros contra inundações e previsão em tempo atual, entre outras medidas que podem ser tomadas.

Os principais elementos que incluem uma obra de macrodrenagem são os seguintes: canais; dissipadores de energia; barragens de assoreamento; vertedouros; bacia de acumulação e bacias dissipadoras (DAEE, 1990; Martins, 1995; Frendrich, 1997b e Garcias, 1997). Segundo esses autores esses elementos foram descritos da seguinte maneira:

1. Canais: são geralmente projetados para escoar águas pluviais ou servidas. Podem ser artificiais ou naturais, abertos ou fechados, e os principais matérias utilizados para sua estabilização são os seguintes: revestimento vegetal, concreto, concreto armado, gabiões, alvenaria, geotêxtil, etc. 
Para Martins (1995), os canais podem ser artificiais ou naturais, dependendo da situação de cada obra, pois elas envolvem principalmente custos de implantação e manutenção, condições para sua execução, remoção e relotação das populações ribeirinhas. Aconselha ainda que se observe com critério se ao longo desses canais existirá a necessidade de emprego de estruturas especiais, como pontes, travessias sob aterros (por ex, bueiros), transição de seção, mudanças de declividade (por ex., degraus), confluências, etc.,pois essas obras podem interferir diretamente no desempenho hidráulico do projeto inicial de instalação do canal;

2. Dissipadores de energia: são colocados na saída dos canais ou galerias, e têm a finalidade de reduzir a velocidade de águas, de forma a permitir um fluxo tranqüilo no talvegue receptor (Galerini et al.,1995 e Galerini, 1995 ). Para os autores os tipos de dissipadores modificam-se em função da dissipação de energia hídrica que pode ser efetuada induzindo-se o jato d'água a um choque com um defletor vertical, ou por meio da formação de ressaltos hidráulico.

Os tipos mais empregados no Brasil são: de vigas de impacto confinadas para dissipação de energia Bradley-Peterka e Ms(Munir Saab), estes são geralmente utilizados apenas nas extremidades de tubos de concreto e possuem custo elevado; e de mergulho (Bacia de Mergulho e Ressalto hidráulico), geralmente empregados em extremidades de canais:

- $\quad B P$ (Bradley-Peterka), são normalmente indicadas para vazões de até $11,00 \mathrm{~m}^{3} / \mathrm{s}$ e velocidade de escoamento inferior a $9 \mathrm{~m} / \mathrm{s}$.

- MS (Munir Saab), que utiliza um paramento vertical para diminuir a velocidade de chegada. É constituído em concreto armado e pode ser projetado com fundações direta ou indireta;

- Bacia de Mergulho: esse tipo não utiliza parâmetros de choque e não necessita de caixa para o seu confinamento; constitui-se de uma escavação no terreno, com forma circular, revestida com rochas, cujos diâmetros médios devem ser diretamente proporcionais á energia cinética, e protegida com uma camada filtrante em sua parte inferior (Figura 2.10). De construção relativamente simples e com baixo custo, tem sido utilizada na 
maioria das obras, principalmente por permitir rebaixamento do terreno a jusante:

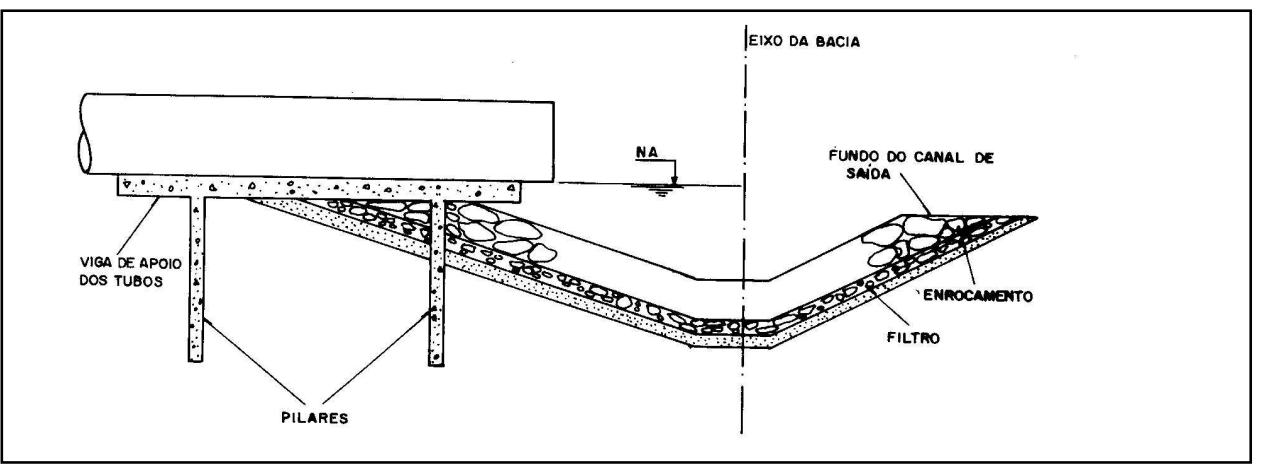

Figura 2.10: Exemplo de dissipação tipo mergulho (Pontes, 1980 e Frendrich, 1997).

- Ressalto hidráulico: Esse tipo é geralmente projetado para canais abertos e são dimensionados considerando-se a velocidade de chegada

3. Barragens: são construídas para armazenar e reter as água pluvial $e$ matérias inconsolidados. As formas e dimensões dependerão do material utilizado e da natureza do substrato rochoso e dos materiais inconsolidados, podendo ser construídas pequenas barragens com intervalos determinados, conhecidas como escalonadas, a Tabela 2.6 mostra algumas vantagens $e$ desvantagens da utilização de alguns tipos de barragens. Segundo Souza (2001), os materiais geralmente utilizados são os tipos "pedras' soltas, alvenaria (tijolo, rochas), gabiões, solos, telas de arame, sacos plásticos ou de nylon preenchidos com concreto, solo cimento ou solo, concreto (gravidade), concreto armado $e$ madeira (paus roliços ou pranchões, tocos de árvores, bambus e folhas de plantas lenhosas "paliçadas"). Algumas dessas estruturas encontram-se ilustradas na Figura 2.11. 


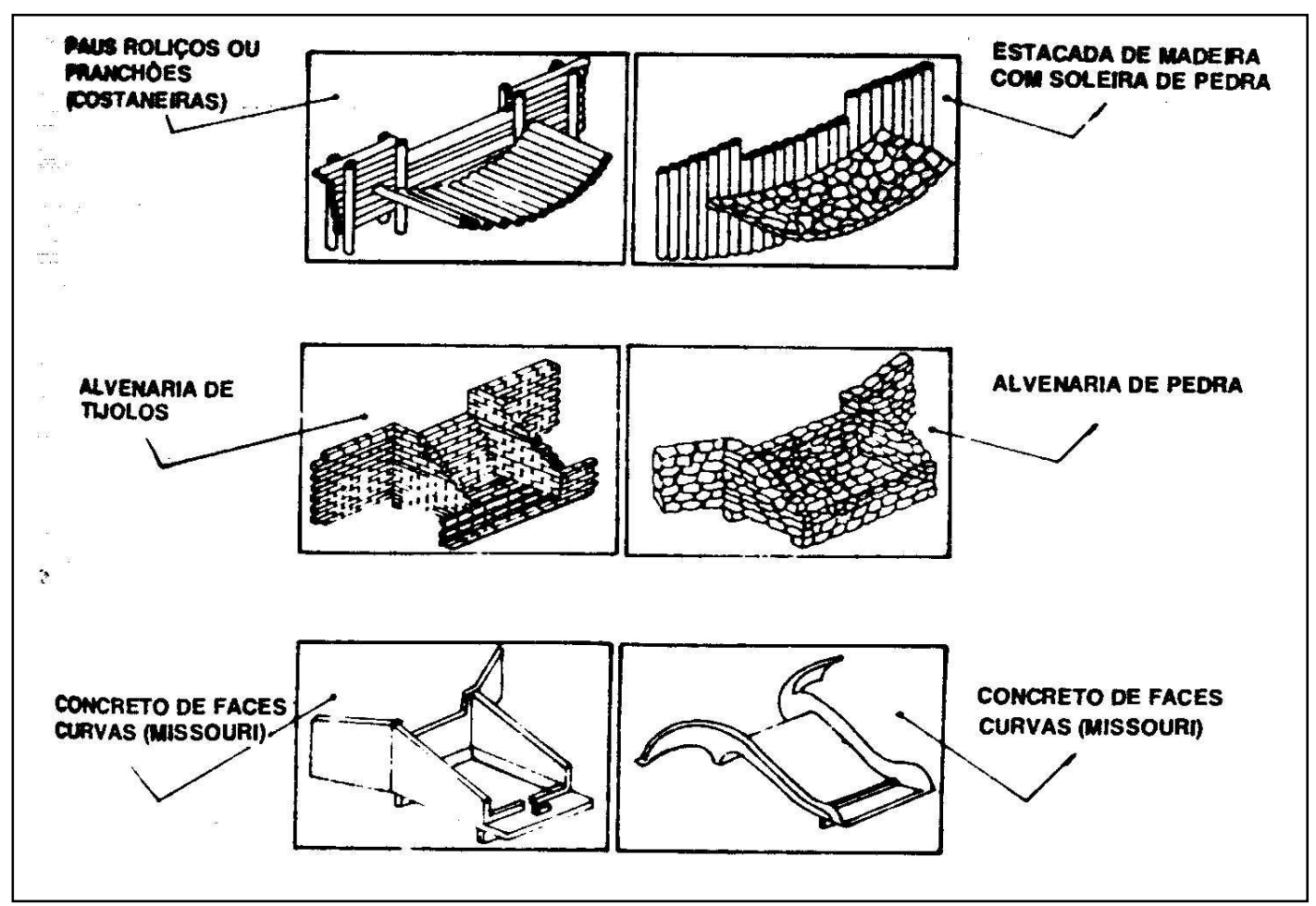

Figura 2.11: Tipos de estruturas de Barragens (Bertoni \& Lombardi Neto, 1999)

Tabela 2.6- Mostrando as vantagens e desvantagens na utilização na utilização de diferentes tipos de barragens (DNOS, 1992).

\begin{tabular}{|c|c|c|}
\hline Tipo de Barragens & Vantagens & Desvantagens \\
\hline $\begin{array}{c}\text { Barragens em } \\
\text { gabiões }\end{array}$ & $\begin{array}{l}\text { - Facilidade na construção, pois pode-se } \\
\text { trabalhar sobre a lamina de água em locais de } \\
\text { difícil acesso: } \\
\text { - Apresentam excelentes resultados em } \\
\text { talvegues estreitos com boas condições de } \\
\text { esgotamento das ombreiras }\end{array}$ & $\begin{array}{l}\text { - Vários anos de observação } \\
\text { mostraram mau funcionamento } \\
\text { nos casos de seção muito largas, } \\
\text { solo saturados com baixa } \\
\text { capacidade de suporte; } \\
\text { - Não suporta rebaixamento do } \\
\text { terreno á jusante; } \\
\text { - É sujeita a depredação. }\end{array}$ \\
\hline $\begin{array}{l}\text { Barragens de Terra } \\
\text { com vertedor em } \\
\text { superfície livre }\end{array}$ & $\begin{array}{l}\text { - Facilidade de execução, pois utiliza materiais } \\
\text { e mão-de-obra locais; } \\
\text { - Suporta variações acentuadas no perfil de } \\
\text { assoreamento; } \\
\text { - Facilidade na execução do vertedor, que pode } \\
\text { ser construído fora do talvegue: } \\
\text { - Pode ser utilizada na maioria das situações, } \\
\text { independente das dimensões da seção } \\
\text { transversal. }\end{array}$ & $\begin{array}{l}\text { - Exige monitoramento constante } \\
\text { e manutenção; } \\
\text { - Exige muito rigor na execução } \\
\text { dos drenos e filtros, tendo em } \\
\text { vista as características do solo. }\end{array}$ \\
\hline $\begin{array}{c}\text { Barragens de Terra } \\
\text { com vertedor tipo } \\
\text { "cachimbo". }\end{array}$ & $\begin{array}{l}\text { - Facilidade de execução utiliza materiais e } \\
\text { mão-de-obra locais; } \\
\text { - Suporta variações no perfil de equilíbrio: } \\
\text { - Baixo custo de execução em relação a outros } \\
\text { tipos de barragens; } \\
\text { - Pode ser executada na maioria das situações, } \\
\text { independente das dimensões da seção } \\
\text { transversal. }\end{array}$ & $\begin{array}{l}\text { - Exige monitoramento constante } \\
\text { e manutenção } \\
\text { - Exige rigor na execução de } \\
\text { drenos e filtros; } \\
\text { A variação do perfil de } \\
\text { assoreamento, muito difícil de } \\
\text { ser previsto com exatidão, pode } \\
\text { causar obstrução na saída da } \\
\text { galeria. }\end{array}$ \\
\hline
\end{tabular}


Segundo DAEE (1990), obras de represamento constituem-se de pequenas barragens ou diques constituídos no interior da voçoroca, com a finalidade de reter a energia da água e promover assoreamento de sedimentos transportados. A tipologia dessas obras varia em função da complexidade $e$ dimensionamento da voçoroca. Sendo que os principais problemas verificados nessas obras referem-se ao seu subdimensionamento, problemas de fundações $e$ de percolação pela fundação e pelas ombreiras. Na Figura 2.12 é mostrado um esquema de uma barragem do tipo escalonada.

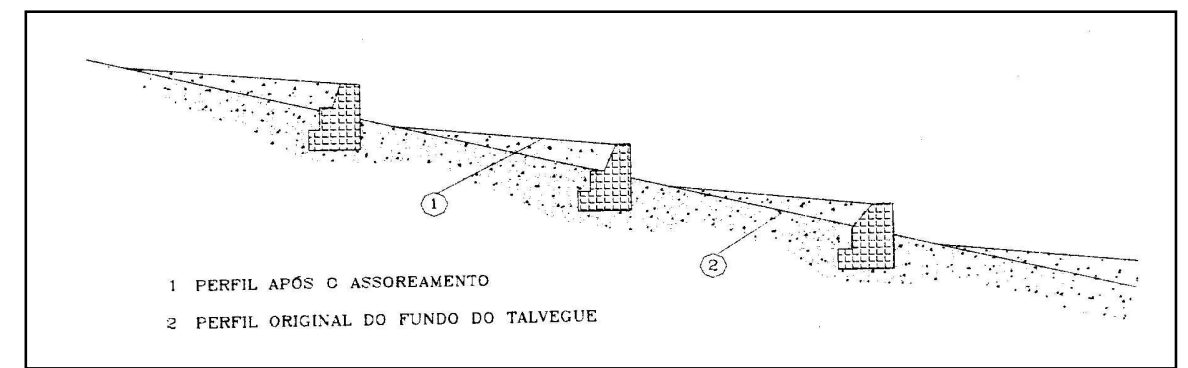

Figura 2.12: Sistema de Barragens Escalonadas (Ridente \& Almeida Filho, 1998).

Vertedouros: são estruturas construídas em locais de barramento da água escoada no interior da voçoroca, tendo como principal função a condução controlada da água em excesso, ou seja, são obras complementares às barragens (DAEE,1990). Os tipos mais empregados são: de queda, calha e em degraus "cachimbo". Os vertedouros de queda são usualmente limitados para quedas de até $3 m$, e os tipos calhas e em degraus "cachimbos" normalmente são empregados para quedas maiores. Podem ser construídos de diversas formas como pode se ver na Tabela 2.8.

Segundo (Souza, 2001) os principais materiais empregados em vertedouro são concreto e gabiões. É a escolha do tipo de vertedouro dependerá do tipo de obra que será aplicada, sendo necessária, para cada tipo específico, uma equação que calcule a descarga que ocorre nos vertedores, como exemplificado na Tabela 2.7.

Tabela 2.7- Tipos de vertedores, equação para calculo de Vazão e parâmetros.

\begin{tabular}{|c|c|l|}
\hline Tipo & Equação & \multicolumn{1}{c|}{ Parâmetros } \\
\hline Soleira Livre & $Q=c L h^{3 / 2}$ & $\begin{array}{l}1,8<c<2,2,(c-\text { coeficiente de descarga) onde: } \\
Q=\text { vazão }\left(\mathrm{m}^{3} / \mathrm{s}\right) ; \\
\mathrm{L}=\text { largura do vertedor }(\mathrm{m}) ; \\
\mathrm{h}=\text { altura da soleira livre }(\mathrm{m}) ;\end{array}$ \\
\hline Tulipa & $Q=c \pi d h^{3 / 2}$ & $\begin{array}{l}1,9<c<2,1, \text { onde: } \\
\mathrm{Q}=\text { vazão }\left(\mathrm{m}^{3} / \mathrm{s}\right) ; \\
\mathrm{d}=\text { diâmetro: } \\
\mathrm{h}=\text { altura da lamina de água; }\end{array}$ \\
\hline Submerso & $Q=\mu A(2 g H)^{1 / 2}$ & $\begin{array}{l}0,4<\mu<0,6, \text { onde: } \\
\mathrm{Q}=\text { vazão }\left(\mathrm{m}^{3} / \mathrm{s}\right) ; \\
A=\text { área do orifício }\left(\mathrm{m}^{2}\right) ; \\
\mathrm{H}=\text { desnivel entre o Na de montante e jusante; }\end{array}$ \\
\hline
\end{tabular}


Tabela 2.8: Determinação dos tipos de Vertedores, suas vantagens e limitações em seu uso (DNOS, 1992).

\begin{tabular}{|c|c|c|c|c|c|}
\hline Tipo & Descrição & Mat. de construção & Adaptabilidade & Vantagens & Limitações \\
\hline $\begin{array}{l}\text { Vertedor de Queda com } \\
\text { entrada direta }\end{array}$ & $\begin{array}{l}\text { É uma estrutura de represamento. Á água } \\
\text { passa pela abertura da barragem, caindo numa } \\
\text { base protegida aproximadamente em nivel ou } \\
\text { numa bacia de dissipação e então passa ao } \\
\text { canal de jusante. }\end{array}$ & $\begin{array}{l}\text { - Concreto armado e Simples } \\
\text { - Alvenaria de pedra } \\
\text { - Escos de concreto } \\
\text { - Pranchas e Madeira bruta } \\
\text { - Metal pré-fabrica de aço } \\
\end{array}$ & $\begin{array}{l}\text { É uma estrutura eficiente para } \\
\text { controlar quedas ou diferenças } \\
\text { de nivel relativamente pequenas, } \\
\text { normalmente até } 3 \text { metros. }\end{array}$ & $\begin{array}{l}\text { Este tipo de construção é geralmente muito } \\
\text { estável, a abertura é retangular é menos } \\
\text { suscetivel de ser obstruída por detritos do } \\
\text { que outras estruturas de mesma capacidade e } \\
\text { é relativamente fácil de construir. }\end{array}$ & $\begin{array}{l}\text { A estrutura é de uso limitado a locais onde } \\
\text { a diferença de nivel é de } 3 \mathrm{~m} \text { ou menores, } \\
\text { tornando-se cara quando a capacidade de } \\
\text { projeto é de menos de } 2,8 \mathrm{~m}^{3} / \mathrm{s} \text { quando } \\
\text { comparada com outros tipos de } \\
\text { estruturas. }\end{array}$ \\
\hline $\begin{array}{l}\text { Vertedor de Queda com } \\
\text { caixa de entrada }\end{array}$ & $\begin{array}{l}\text { É uma caixa retangular, aberta no topo e na } \\
\text { parte de jusante. O escoamento das chuvas, } \\
\text { dirigidas á caixa por diques e muros de } \\
\text { cabeceira, entra pela parede de montante e } \\
\text { paredes laterais. A água cai numa base } \\
\text { protegida e sai através da extremidade } \\
\text { aberta de jusante. }\end{array}$ & $\begin{array}{l}\text { - Concreto armado (melhor) } \\
\text { Blocos de concreto armado ou sacos } \\
\text { de solo-cimento podem ser usados para } \\
\text { pequenas quedas (1 } \mathrm{m} \text { ou menos) e } \\
\text { canais estreitos. }\end{array}$ & $\begin{array}{l}\text { O maior perímetro da caixa de } \\
\text { entrada permite passagem de } \\
\text { grandes quantidades de água } \\
\text { sobre ela com cargas (altura } \\
\text { relativamente baixa). }\end{array}$ & $\begin{array}{l}\text { Este vertedor pode ser usado para os } \\
\text { mesmos propósitos que o vertedor de queda } \\
\text { com entrada direta. Um dos seus maiores } \\
\text { usos é para o controle da declividade e da } \\
\text { erosão em valas abertas onde a largura do } \\
\text { canal seja limitada. }\end{array}$ & $\begin{array}{l}\text { As mesmas do vertedor de queda com } \\
\text { entrada direta. }\end{array}$ \\
\hline Vertedor com tubulação & $\begin{array}{l}\text { É um conduto fechado geralmente projetado } \\
\text { para conduzir água sob pressão de cima de um } \\
\text { aterro para um nivel mais abaixo. Um dique de } \\
\text { terra é exigido para por em carga o vertedor. } \\
\text { Assim, a função usual de um vertedor com } \\
\text { tubulação é conduzir uma porçã do do } \\
\text { escaomento superficial através de ou sob um } \\
\text { aterro sem erosão. }\end{array}$ & $\begin{array}{l}\text { - A estrutura de entrada pode ser: - } \\
\text { Concreto armado e Simples } \\
\text { - Blocos de concreto, aço, etc. } \\
\text { O conduto pode ser: } \\
\text { - Concreto armado } \\
\text { - manilhas de barro ou concreto } \\
\text {-tubos de metal corrugado ou liso. } \\
\text { Cada um deve ter juntas } \\
\text { impermeáveis. }\end{array}$ & $\begin{array}{l}\text { Esta estrutura é muito eficiente } \\
\text { para controlar cabeceiras de } \\
\text { vocorocas altas, de } 3 \text { metros } \\
\text { para cima. } \\
\text { É bem adaptada a lugares que } \\
\text { proporcionam armazenamento } \\
\text { temporário a montante da } \\
\text { entrada. }\end{array}$ & $\begin{array}{l}\text { Para cargas altas, exige menos material na } \\
\text { sua construção que o vertedor de queda. } \\
\text { Onde uma quantidade apreciável puder ser } \\
\text { armazenada temporariamente, a capacidade } \\
\text { do vertedor pode ser eventualmente } \\
\text { reduzida. Esta redução de descarga pode ser } \\
\text { resultado num pico de fluxo menor canal } \\
\text { abaixo e vir a ser un fator favorável á } \\
\text { estabilidade da gradeá jusante. }\end{array}$ & $\begin{array}{l}\text { Esta sujeita a obstruções por detritos. } \\
\text { limitada a locais onde diques de terra } \\
\text { satisfatórios possam ser construídos. }\end{array}$ \\
\hline $\begin{array}{l}\text { Vertedor de canaleta de } \\
\text { concreto }\end{array}$ & $\begin{array}{l}\text { Estes vertedores constam ordinariamente de } \\
\text { um canal aberto, com seu eixo reto e largura } \\
\text { constante. O trecho superior ou canal de } \\
\text { entrada tem fraca declividade e é seguindo } \\
\text { por uma estrutura de controle. Logo vem um } \\
\text { trecho em curva vertical, um canal de } \\
\text { descarga com declive acentuado e uma saída. }\end{array}$ & $\begin{array}{l}\text { - Concreto armado é o material mais } \\
\text { amplamente usado e mais seguro para } \\
\text { canaleta grande. }\end{array}$ & $\begin{array}{l}\text { Adapta-se particularmente a } \\
\text { quedas altas, sendo uma } \\
\text { estrutura completa de } \\
\text { escoamento, e onde as condições } \\
\text { de terreno não permitam o uso } \\
\text { de uma estrutura de retenção. }\end{array}$ & $\begin{array}{l}\text { É geralmente mais econômica que estruturas } \\
\text { de entrada em queda quando são exigidas } \\
\text { capacidades grandes. }\end{array}$ & $\begin{array}{l}\text { Existe a possibilidade de ser solapado por } \\
\text { pequenos animais. Em locais de drenagem } \\
\text { precária, a percolação pode enfraquecer } \\
\text { as fundações. Deve ser colocado sobre } \\
\text { aterros compactados ou sobre o terreno } \\
\text { original com proteção. }\end{array}$ \\
\hline $\begin{array}{l}\text { Vertedor de canaleta de } \\
\text { concreto sem forma }\end{array}$ & $\begin{array}{l}\text { Este vertedor é construído em concreto, sem } \\
\text { forma especial. O subleito é escavado nas } \\
\text { dimensões e contornos da estrutura. O } \\
\text { concreto é colocado contra estes subleitos na } \\
\text { profundidade exigida e alisado com colher de } \\
\text { pedreiro. Este é bem adaptado as áreas onde } \\
\text { há falta de mão-de-obra especializada. }\end{array}$ & $\begin{array}{l}\text { - Deve ser usado concreto de no } \\
\text { mínimo } 176 \mathrm{~kg} / \mathrm{cm}^{2} \text { de resistência aos } \\
28 \text { dias. Exige-se reforço com aço e } \\
\text { pode ser usada também malha de } \\
\text { arame soldado. }\end{array}$ & $\begin{array}{l}\text { Este tipo de estrutura é usado } \\
\text { para cargas hidráulicas menores } \\
\text { e onde sejam exigidos os } \\
\text { vertedores de baixa capacidade. } \\
\text { Adapta-se a regiões sem } \\
\text { variações extremas de } \\
\text { temperatura. }\end{array}$ & $\begin{array}{l}\text { O vertedor é fácil de construir. Mão-de-obra } \\
\text { inexperiente pode ser treinada para instalar } \\
\text { esta estrutura em pouco tempo. A eliminação } \\
\text { das formas de parede trás maior economia } \\
\text { em tempo e dinheiro. }\end{array}$ & $\begin{array}{l}\text { É limitado a terrenos que tenham boa } \\
\text { drenagem natural. Sua vida útil não é longa } \\
\text { como para outras estruturas. }\end{array}$ \\
\hline $\begin{array}{l}\text { Vertedor de canaleta } \\
\text { gramada }\end{array}$ & $\begin{array}{l}\text { É um curto trecho íngreme e gramado } \\
\text { construído para conduzir uma vazão } \\
\text { determinada, numa velocidade segura. }\end{array}$ & $\begin{array}{l}\text { - A vegetaçãa exigida pode ser } \\
\text { estabelecida por enlevamento ou, se } \\
\text { a água puder ser desviada da seção } \\
\text { por tempo suficiente, pode ser } \\
\text { estabelecida por semeadura. }\end{array}$ & $\begin{array}{l}\text { É adaptada a pequenas bacias e } \\
\text { lugares onde a grama boa e } \\
\text { densa possa ser desenvolvida e } \\
\text { conservada. O curso d'água } \\
\text { abaixo da canaleta deve ser } \\
\text { estável. }\end{array}$ & $\begin{array}{l}\text { Baixo custo de material e pode ser construída } \\
\text { por mão-de-obra não especializada. }\end{array}$ & $\begin{array}{l}\text { É Limitada a lugares de solo bom e onde a } \\
\text { velocidade do escoamento da canaleta seja } \\
\text { suficientemente baixa para manterá } \\
\text { cobertura vegetal de grama. Isto significa } \\
\text { pequenas bacias e baixas quedas d'água, } \\
\text { onde não existe um escoamento contínuo. }\end{array}$ \\
\hline
\end{tabular}


5. Bacia de Aculumação: são conhecidas também como bacias de amortecimento de cheias. Têm a função de receber as águas provenientes da drenagem urbana e um emissário (tubulações ou galerias subterrâneas e canais abertos) de diâmetro reduzido conduz a água acumulada na bacia até um local conveniente (Galerani et al. 1995).

Os autores Galerani et al. (1995), alertam que a execução deste tipo de obra só passa a ser viável economicamente, a partir de momento em que os gastos necessários para sua execução sejam menores do que a economia feita pela redução do diâmetro do emissário, em função do seu comprimento. Além disso, eles mostram as principais vantagens e desvantagens de serem utilizados este tipo de obra. As vantagens apontadas são: redução do assoreamento $e$ do impacto da vazão sobre o córrego receptor $e$ do custo de implantação em relação a um emissário convencional. $E$ as desvantagens apresentadas referem-se á necessidade periódica de limpeza e desassoreamento da bacia.

6. Bacias Dissipadoras: têm a função de oferecer proteção contra o solapamento das barragens. A dissipação da energia das águas, realizada principalmente pelos extravasadores ou condutos de descarga, pode provocar a formação de processos erosivos no leito e nas margens à jusante das barragens (Frendrich, 1997b). Por isso, é preciso que sejam construídas bacias dissipadoras que convertam a energia cinética em energia potencial antes que o escoamento siga adiante. Os materiais utilizados nestas bacias podem ser o concreto e ou gabiões. O autor recomenda que sejam adotadas medidas preventivas adequadas para as condições do meio físico local, quando da realização inadequada e blocos de rocha vulneráveis á ação erosiva das águas em movimento podem ser solapadas com velocidade de 0,60 a $0,9 \mathrm{~m} / \mathrm{s}$.

Galerini et al. (1995), com experiências práticas no controle dos processos erosivos na região noroeste do estado do Paraná, apontam as vantagens e desvantagens de algumas obras de macrodrenagem utilizadas na estabilidade de voçorocas. As obras utilizadas foram dissipadores de energia (Bradeley-Peterka e MS), barragens em terra com vertedores tipo cachimbo, em superfície livre e gabiões.

Cruz \& Silva (1995) discutem alguns critérios técnicos que devem ser adotados na correta utilização de algumas estruturas empregadas na contenção de processos erosivos, baseados em estudos realizados em várias estruturas instaladas em algumas erosões na cidade de Bauru (SP), que apresentam deficiências em suas estruturas hidráulicas. Os autores alertam que, muitas vezes, os técnicos envolvidos em problemas oriundos de 
processos erosivos não dispõem de conhecimentos e experiências no trato com soluções que exigem noções de hidráulica, hidrologia e da dinâmica de transporte de sedimentos.

\subsection{2- OBRAS DE CONTENÇÃO DE TALUDES.}

Como obras convencionais de contenção de taludes, podem ser citadas: plantação de vegetação, estabilização da inclinação de taludes, aterramento, gabião, muro de arrimo, cortinas atirantadas, terra armada, parede diafragma $e$ jateamento. A sua utilização permite que o solo resista à erosão causada pelo escoamento superficial ou subterrâneo.

A estabilização de taludes é composta pela proteção da camada superior do solo contra a energia do impacto das chuvas (Morgan, 1986), proteção do solo contra a força de arrasto do escoamento superficial, proteção do solo contra gradiente hidráulicos elevados no subsolo causado por concentrações do fluxo subterrâneo (Zaslavsky 1970 apud Goldstein, 1998).

Segundo GOLDSTEIN (1998), a estabilização de taludes com métodos vegetativos é a mais usada geralmente. Este método é econômico e eficiente, porém têm alguns fatores limitantes. O crescimento vegetativo é lento dependendo das condições físicas e climáticas apropriadas para seu desenvolvimento. É importante entendermos o modo com que atua a estabilização do solo com auxilio vegetativo. Este método é baseado na cobertura vegetal da superfície do solo para absorver a energia do impacto da chuva. As raízes e matéria orgânica da cobertura vegetal aumentam a capacidade de infiltração do solo diminuindo assim o volume de escoamento superficial. Uma das desvantagens deste método é a lentidão com que os vegetais se desenvolvem. Não adianta semear um talude com o risco que uma enxurrada arraste as sementes antes de se desenvolverem. $O$ auxílio de métodos geotécnicos para estabilizar e vegetar um talude ou até mesmos canais de drenagem garantem bons resultados num prazo extremamente curto.

\subsection{3-REVEGETAÇÃO E GEOSSINTÉTICOS}

A vegetação é uma das medidas mais eficazes e baratas utilizadas que podem ser usadas para o controle de estabilização do processo de erosão (Figura 2.13). Como medida preventiva é necessário plantar o máximo possível de touceiras de bambu, grama, capim, etc. para proteger os pontos vulneráveis tais como saídas de sangras, canaletas 
longitudinais e erosões já existentes fora da plataforma. Para Vidal (1995), a proteção do solo superficial através de vegetação é eficiente, econômica e esteticamente agradável no controle da erosão.

A necessidade de aumentar a eficiência da proteção vegetal em alguns tipos de solo deu origem à utilização dos produtos sintéticos que auxiliam o crescimento da vegetação, reforçando seu sistema radicular, colaborando, assim, com a estabilização em longo prazo do solo superficial, através da sua interação com a vegetação plantada (Vidal, 1995).

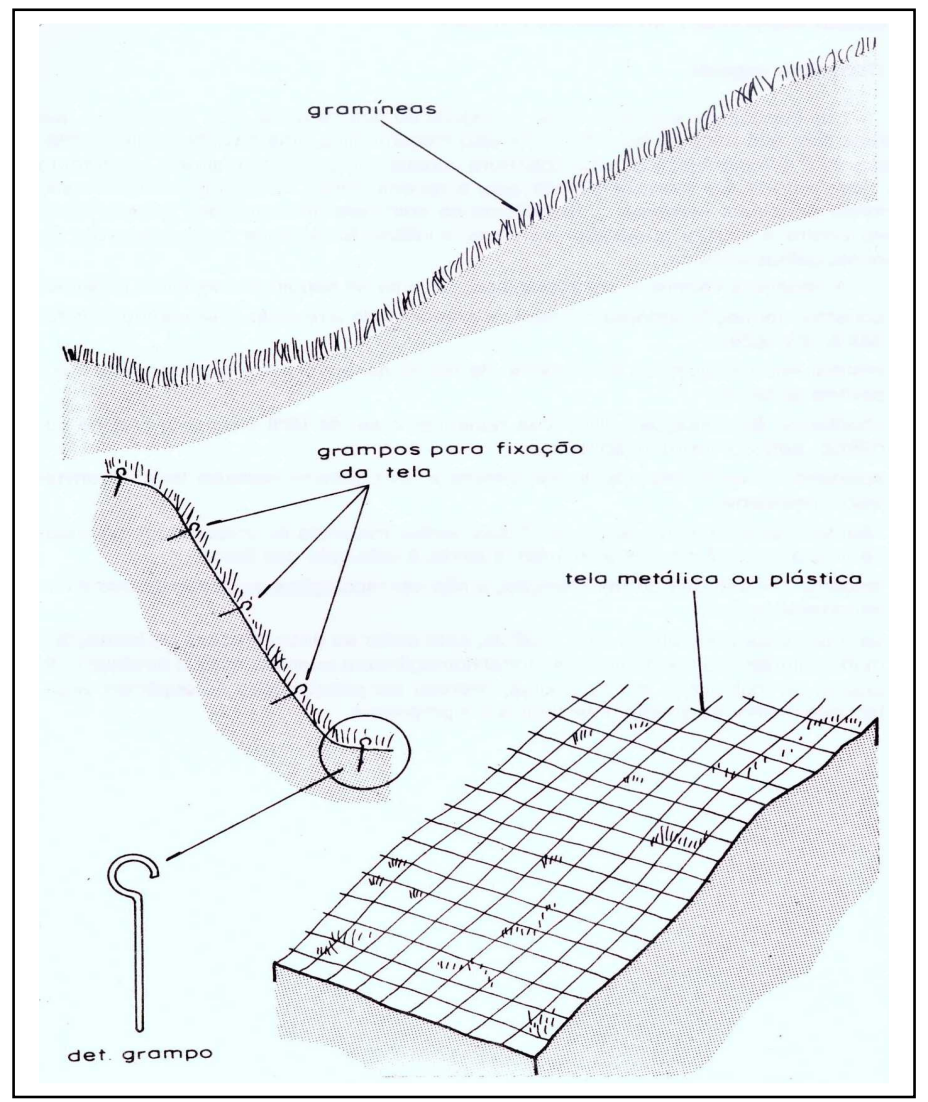

Figura 2.13: Esquema de retaludamento com cobertura vegetal com grama (IPT, 1991).

Pereira (2001) sugere a utilização da bioengenharia para ajudar no controle de erosão, como por exemplo, o uso de geotêxteis. Segundo este autor, existem diversos geotêxteis compostos de produtos totalmente biodegradáveis com as mais variadas aplicações em trabalhos de recuperação e proteção ambiental, controle de processos erosivos e estabilização de encostas e taludes. Dentre os geotêxteis destacam-se a tela e a manta. As telas são produtos entrelaçados por fibras têxteis e que apresentam maior translucidez e grande permeabilidade, enquanto que as mantas são produtos entrelaçados por adesivos biológicos, sendo menos translúcidos e menos permeáveis. Segundo Vidal 
(1995), a utilização de produtos sintéticos que auxiliam o crescimento da vegetação se deu devido à necessidade de aumentar a eficiência da proteção vegetal.

A Hidrossemeadura é uma técnica que semeia grandes áreas em curto prazo de tempo e a custos relativamente baixos. Consiste no lançamento de sementes de gramíneas, leguminosas ou outros vegetais sobre o talude, em meio aquoso, que contém também um elemento fixador (adesivo) e nutriente (adubos). É ideal para locais de solos áridos, inférteis e sem coesão, pois através deste método injeta-se vida no solo, uma vez que a mistura poderá ter a composição que o solo necessitar, de sementes e insumos compostos por fertilizantes orgânicos e inorgânicos. É indicada também para taludes íngremes (Vidal, 1995).

Segundo Magalhães (2001) o plantio interno com desvio pluvial tem como função: proteção do solo afetado; controle da erosão; através das etapas: desviar as águas pluviais; confinar plantio através de meios-fios; usando como material constituinte as gramas, capins, bambuzinhos, etc.

Existem outros métodos alternativos que podem ser empregados no controle da erosão, como, por exemplo, os geossintéticos. Esses materiais são utilizados conjuntamente com outros produtos de várias técnicas de caráter corretivo, mitigador e preventivo (drenos, barragens, etc.). São normalmente empregados na área urbana (Souza, 2001). Podemos dividir os materiais geossintéticos em duas classes: degradáveis e não degradáveis. Sendo que os materiais pertencentes à primeira classe são mais usados para controle de erosão, pois são usados para garantir a proteção inicial e imediata do solo até que a cobertura vegetal se desenvolva. Temos como exemplo desta classe os tapetes $e$ redes de fibra de juta ou de coco e alguns geotêxteis

Para Morgan \& Rickson (1995), a bioengenharia apresenta crescente evolução em seus estudos. Tradicionalmente a vegetação estava ligada ao papel de cobertura nos estudos de processos erosivos, mas, com o desenvolvimento de técnicas que utilizam diferentes tipos de geotêxteis (natural ou sintético), estes passaram a ter um papel diferenciado no emprego de técnicas de controle de processos erosivos (tabela 2.9).

O geotêxtil pode ser utilizado em vários tipos de obras relacionadas com o controle dos processos erosivos, tais como: na proteção de taludes, encostas de taludes, margens de rios, lagos e canais, barragens, canais impermeáveis, aterros, obras viárias e vicinais.

Outra proposta alternativa para o controle de voçorocas foi feita por Vilar et al. (1984), com o uso de solos reforçados. Para os autores, as técnicas de reforço do solo 
oferecem vantagens em relação a outros materiais empregados em outras técnicas, pois existe uma grande possibilidade de serem utilizados os materiais locais; as desvantagens referem-se à durabilidade de alguns tipos de matérias empregados no reforço $e$ revestimento. Essa técnica inclui, por exemplo, a construção de estacas de brita ou de areia, de microestacas e de um tipo de reforço (tiras de ferro galvanizado, barras de ferro, malhas de arame ou plástico, tiras de vidro, esteiras de borracha e mantas sintéticas), que, no maciço de solo compactado, vão sendo introduzidos como elementos tradicionadores, que permitem construir um novo material denominado de terra ou solo armado. 
Tabela 2.9: Tipos de geossintéticos utilizados em obras de controle de erosão (www.tenax.net/geossinteticos/index.htm Vidal, 1995;)

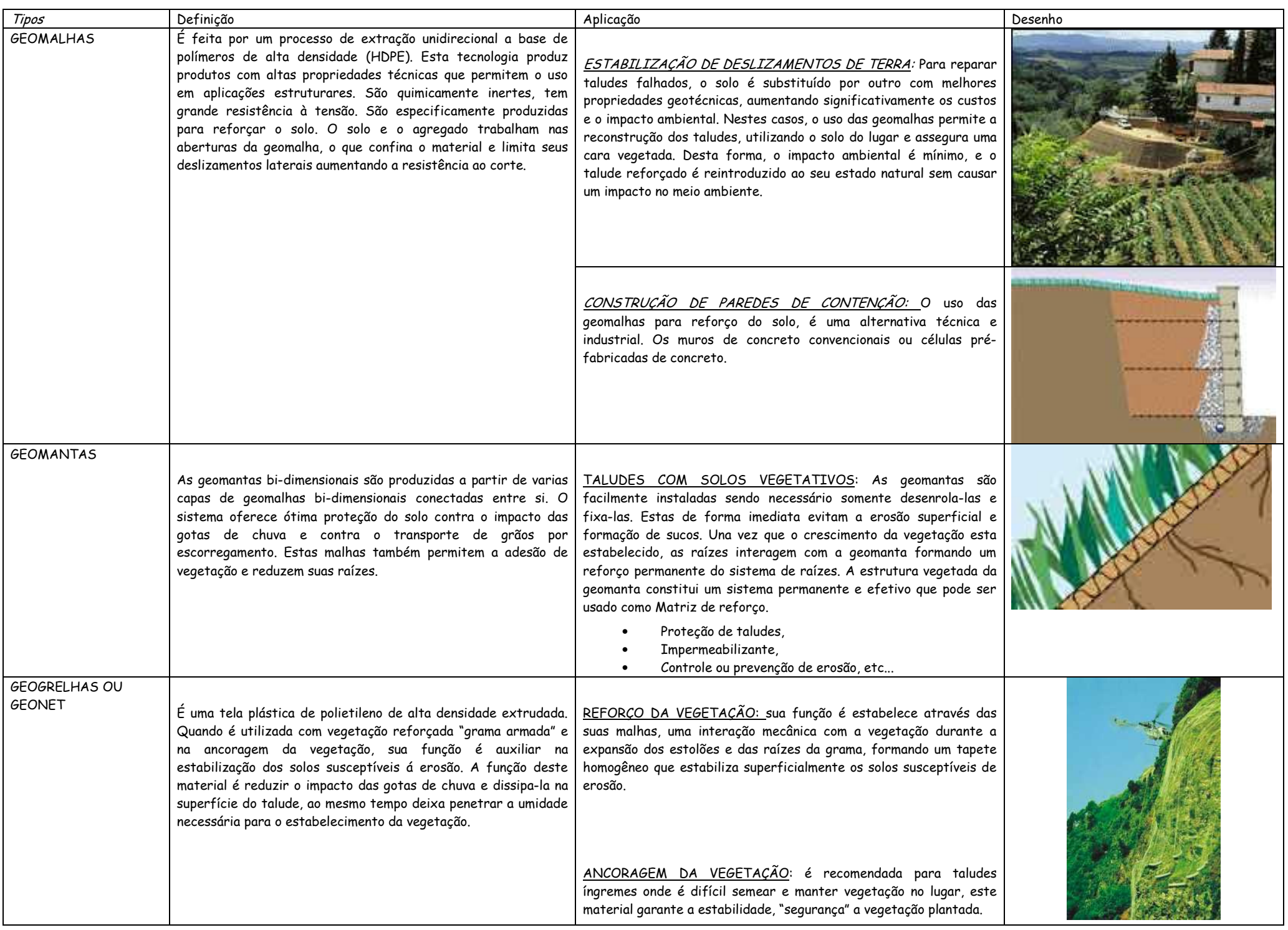




\subsection{4-OBRAS DE ATERRAMENTO}

Segundo Souza (2001) este tipo de obra consiste em aterrar novamente o local erodido. É uma solução que pode ser utilizada quando o processo ainda está se iniciando, nos estágios de sulcos e ravinas. No entanto, quando o processo esta mais adiantado, em geral a solução é inviável economicamente.

A utilização de canalização com aproveitamos do solo, emprego de estruturas de aço corrugado ocorre quando há execuções de canalização dentro da vala criada pela erosão. Permitindo o fechamento da voçoroca, através de aterro controlado, colaborando para o retorno das condições anteriormente existentes. Esta solução é normalmente executada quando o valor do terreno rural ou urbano justifique o custo do aterro necessário para o preenchimento da voçoroca (Mattos, 1995).

Os materiais geralmente empregados são matérias inconsolidados e dependendo das características destes materiais, são empregados os da própria região. No entanto, é necessário observar-se a retirada do material não acarretará o desenvolvimento de uma nova feição erosiva.

Segundo Magalhães (2001) o reaterro com dreno de fundo tem como função: evitar novas erosões e repor o solo, através das etapas: instalação de dreno de fundo, aterramento do solo no local erodido, usando materiais como, brita, tubo, seixo, pedra, etc.

Outra causa de insucesso em obras de controle de processos erosivos foi levantado por Kertzman et al. (1995) e refere-se à água subsuperficial que normalmente não é considerada no aterramento.

\subsection{5- OBRAS DE BARRAMENTO}

Barragens de estabilização intermediárias têm como função: conter a água e solo. A construção segue as seguintes etapas: construir muro de contenção na parte inferior da erosão (subindo pelo cânion sucessivamente a distâncias horizontais tais que dependem de cada caso), o muro deve ser escalonado em degraus e desviar águas pluviais através da construção de banquetas ao redor da crista de toda a erosão. Utilizando os seguintes materiais: pneu, bambu, solo-cimento, tambor, madeira, concreto, palha e etc. (Magalhães, 2001).

Segundo DNOS (1972), as barragens escalonadas são constituídas, nos 
casos mais complexos, por diques, vertedores e dissipadores de energia. $\mathrm{Na}$ prática um ou mais destes elementos são dispensados ou combinados formando uma única estrutura. Pode-se usar eventualmente gabiões constituídos de pedras envoltas em telas de arame galvanizado para construir estas barragens. As aberturas da malha da tela devem ser escolhidas em função das dimensões das pedras. As principais vantagens do uso dos gabiões é sua adptabilidade aos abatimentos da fundação e sua resistência á erosão, que os torna apropriados para a função de barragens vertedoras (Figura 2.14).

Segundo Souza (2001) as formas estruturais e suas dimensões dependerão do material utilizado e da natureza do substrato rochoso e dos materiais inconsolidados.

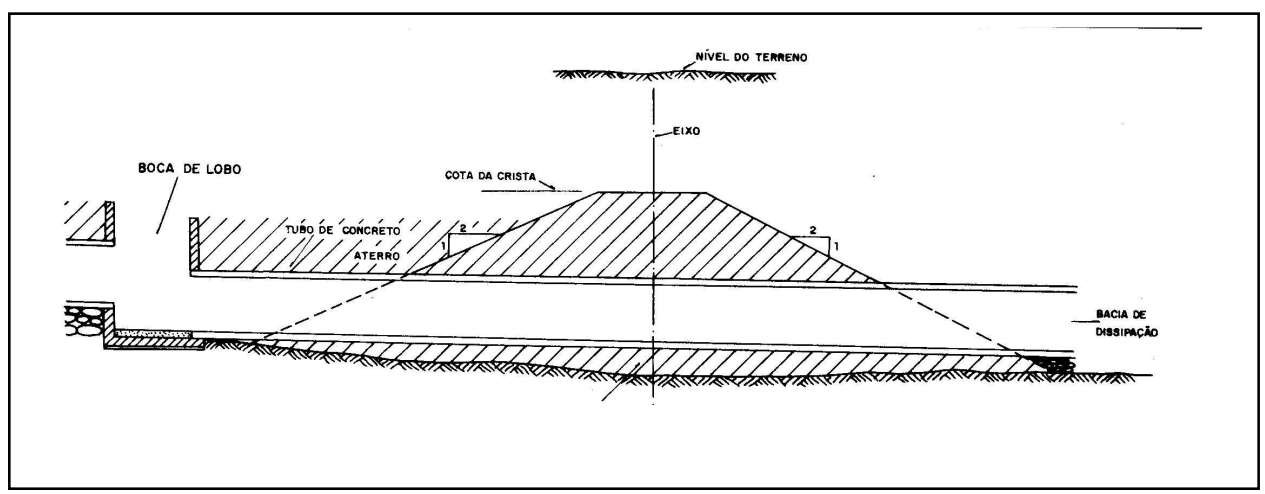

Figura 2.14: Esquema de pequeno barramento projetado em uma voçoroca com vertedor tipo cachimbo ou tulipa (DAEE, 1990).

\subsection{6-TERRACEAMENTO (cordões de nível)}

Terraceamento é a técnica de construir terraços, onde este é formado de um canal e um camalhão feito em nível ou com gradiente, o objetivo principal é de controlar a erosão (GALETI, 1987). O terraceamento da encosta tem como objetivo principal interceptar a água da enxurrada e conduzir o excesso pelo canal.

Para Gomes (1998), o terraceamento é uma prática de conservação de solos que controla a velocidade do escoamento superficial, mas não impede a desagregação do solo pelo impacto da chuva. Quando esses terraços se rompem, podem ocasionar maiores estragos na área, devido à concentração do fluxo. Portanto, essas técnicas devem ser empregadas somente depois de estudos minuciosos sobre o meio físico, domínio de aplicação das técnicas e análise de 
custos.

Segundo Bertoni \& Lombardi Neto (1999), o terraceamento é quando bem planejado e bem construído, reduz as perdas de solo pela erosão, sendo uma das práticas mais eficientes para controlar os processos erosivos. Ainda segundo estes autores existem grandes dificuldades na concepção deste tipo de projeto e os custos de construção $e$ manutenção aumentam à medida que cresce a declividade do terreno, pois a declividade determina a praticabilidade do terraceamento, a tal ponto que sua construção pode-se tornar inviável.

Existem vários tipos de terraços, como o Magnum, Nichols, o de base larga, o de base estreita, o patamar, e o individual. A escolha do tipo a ser construído depende das condições da declividade do terreno e do tipo de solo. Alguns destes, descritos por Bertoni \& Lombardi Neto (1999), encontram-se a seguir:

- O terraço tipo Magnum é construído pelos dois lados do terreno, produzindo assim um terraço de camalhão mais alto este é adaptado para a conservação da água.

- O tipo Nichols é desenvolvido com a movimentação do solo exclusivamente do lado de cima do terreno, com a desvantagem de não poder ser aproveitada para o cultivo a faixa destinada ao canal, sendo assim mais

(A) utilizado para controle de processos erosivos em áreas não agrícolas (Figura

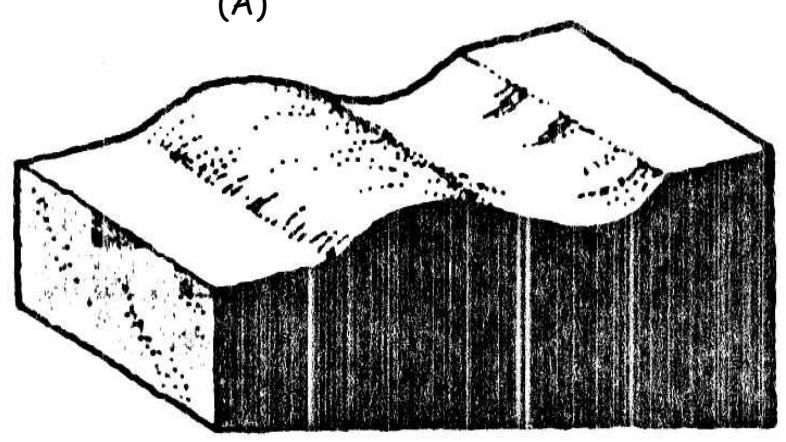

(B)

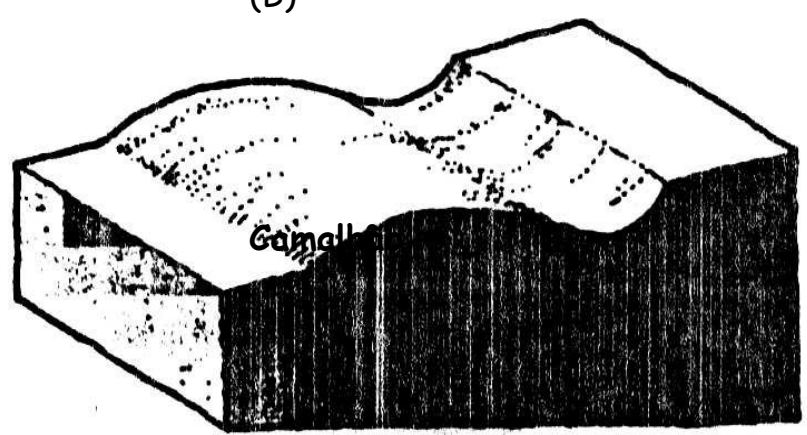

Figura 2.15- Representação em bloco diagrama do terraço tipo Nichols (A) e Representação em bloco diagrama do terraço tipo Base larga (B) Almeida \& Ridente Jr. (2001).

- Terraço tipo base larga são bastante largos, rasos, de suave inclinação, é o mais comum, e é considerado como uma das formas mais seguras de proteção do solo contra os efeitos da erosão, estes terraços podem ser empregados em culturas 
anuais, perenes, e até mesmo em pastagens (Figura 2.15b). A construção deste tipo de terraço é indicada para terrenos de até $12 \%$ de declividade, sendo que para solos de boa permeabilidade pode ser de até $20 \%$, ainda pode ser indicado para terrenos de baixa declividade, como de 0,5\%, onde a topografia, porém, seja formada de grandes lançantes, com a finalidade de reduzir a erosão produzida por grandes concentrações de escoamento superficial. A construção desses terraços para terrenos de topografia irregular não é indicada.

- O terraço de base estreita é uma combinação de valetas e leiras de pequenas dimensões, é bastante utilizado na proteção de culturas perenes. Ao contrário do de base larga, o de base estreita é recomendado para terrenos de maior declividade. $O$ espaçamento entre os terraços será maior quanto mais permeável e menos erodível for o solo, e menor quanto maior for a declividade do terreno.

- Terraço patamar consiste de plataformas construídas em terrenos de grande inclinação, com declividade acima de $20 \%$, formando uma espécie de degraus. É uma prática muito antiga feita para conservação do solo de regiões montanhosas. $A$ grande desvantagem deste tipo de terraço é o seu elevado custo de construção, a sua utilização se restringe a regiões com grande densidade de população e que não tenham terras planas. No controle da erosão, os terraços-patamar são eficientes, pois contribuem para melhor conservação das águas da chuva (Figura 2.16).

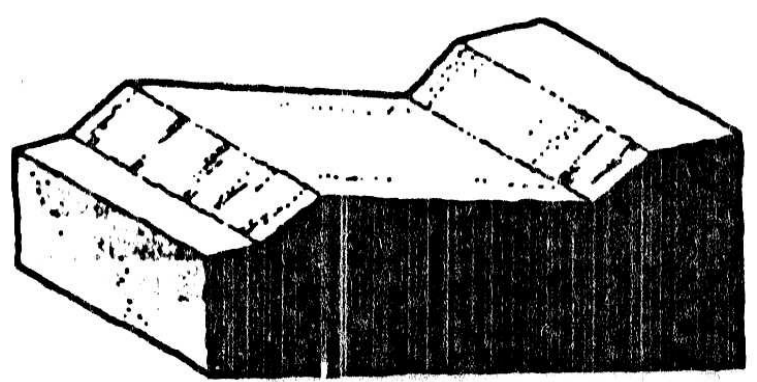

Figura 2.16- Representação em bloco diagrama do terraço tipo patamar Almeida \& Ridente Jr. (2001).

- Terraço individual, quando consiste em um patamar, circular ou oval, construído individualmente para cada planta, é indicado para o controle de erosão nas culturas perenes em terrenos de declividade muito forte. Como vantagem este tipo de terraço reduz a velocidade do escoamento superficial da enxurrada, com maior 
infiltração da água da chuva. A principal desvantagem do terraço individual é o seu alto custo de construção.

De acordo com Bertoni \& Lombardi Neto (1999) o espaçamento entre os terraços é determinado de maneira que a enxurrada não alcance velocidade erosiva, isto significa que a distância entre eles depende da declividade do terreno e do tipo de solo; quanto maior o espaçamento, menor o custo de construção por unidade de área. O terraço pode ser construído com uma seção na forma de $V$ ou com fundo chato; a seção em $V$ é indicada para solos menos permeáveis e o de fundo chato para solos mais permeáveis.

\subsection{7-OBRAS COMPLEMENTARES}

As obras complementares englobam técnicas que podem proporcionar a implantação e o funcionamento adequado das técnicas descritas anteriormente, se utilizadas conjuntamente em determinadas situações. Os procedimentos principais são, por exemplo: obras de pavimentação e drenos.

\subsubsection{1- OBRAS DE PAVIMENTAÇÃO}

Segundo Souza (2001) são importantes no controle dos processos erosivos, mesmo com as obras de microdrenagem e galerias já executadas; têm a função de evitar que o escoamento sobre as ruas desprotegidas desencadeie processos erosivos. Onde o tipo de pavimentação a ser adotado varia com a intensidade do tráfego. No entanto, Galerini et al (1995) recomendam a adoção de pavimentos mais permeáveis, com o intuito de reduzir o volume escoado superficialmente. Os métodos mais utilizados para calçamento são: asfaltamento, concreto, paralelepípedo e blocos octaédricos de concreto. Sendo que os pavimentos permeáveis são basicamente de três tipos: asfalto poroso, concreto poroso e blocos de concreto vazado preenchido com material granular, como areia ou vegetação rasteira como grama.

O elemento essencial no desempenho destas medidas indicadas é a pavimentação das ruas para o adequado funcionamento da rede de drenagem urbana, que garante a estabilização e a eficiência do sistema de drenagem. Portanto, a pavimentação deve ser entendida como parte integrante do sistema, fazendo-se necessária para que essas obras não sejam inutilizadas. 


\subsubsection{2 - DRENOS}

Segundo DAEE (1990), tratar as águas subsuperficiais, provenientes do lençol freático ou do lençol suspenso é um dos maiores desafios existentes na execução de obras em voçorocas, estando pouco desenvolvidas técnicas totalmente eficazes.

O tratamento convencional é feito com a aplicação de drenos enterrados, com objetivo de disciplinamento das águas subsuperficiais, com o intuito de controlar o gradiente hidráulico, impedindo assim o arraste do solo pelo "piping". Os principais tipos de drenos utilizados são: cego (figura 2.17), com material sintético geotêxtil, bambu (figura 2.18), paralelos, espinhas de peixe e grelhas (DAEE, 1990; Ridente Jr. et al, 1999; Ridente Jr. \& Almeida, 1998).

- Dreno Cego: é composto de uma valeta revestida com material filtrante e de um seguimento de tubo perfurado, colocado na saída do dreno sobre o material filtrante instala-se material impermeável, normalmente constituído por argila ou plástico (Figura 2.17).

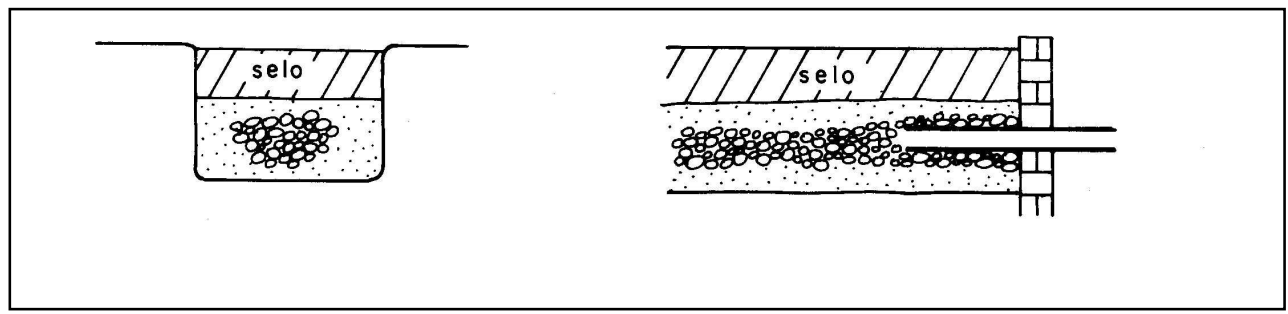

Figura 2.17: Esquema de Dreno Cego (DAEE, 1990).

- Dreno com material sintético geotêxtil: trata-se do revestimento de uma vala com manta geotêxtil de preenchimento com material filtrante de enchimento- após o envolvimento total do material filtrante com a manta de geotêxtil procede-se o fechamento da vala com material impermeável que funciona como selo.

- Dreno de Bambu: é executado com bambus amarrados em feixes, assentados em vala e envolvidos com brita ou geotêxtil - o fechamento da vala é feita com materiais impermeável, como mostra a figura 2.18 . 


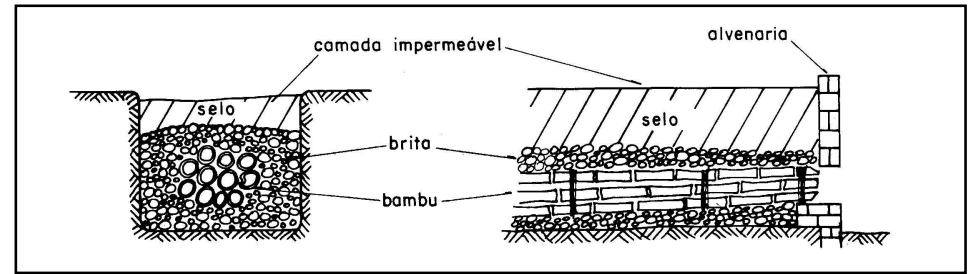

Figura 2.18: Esquema de Dreno de Bambu (DAEE, 1990)

- Paralelos: os drenos são dispostos paralelamente uns aos outros, e deságuam num ou mais coletores.

- Espinha de peixe: Consiste em um dreno central principal, geralmente utilizado com drenos coletores laterais, estendidos até a base dos taludes.

- Grelha: Forma de grelha com trevos paralelos.

Segundo Magalhães (2001) os processos erosivos (ravina e voçoroca) apresentam características diferentes, necessitando soluções próprias, e a sua perfeita caracterização hidrológica, geológica, hidráulica, geotécnica dos solos, topográfica local e dos vales adjacentes. 


\subsubsection{3- LIXO E OUTROS REJEITOS COMO MEDIDA CORRETIVA}

Segundo Cavaguti (1995), durante décadas, a quase totalidade dos municípios brasileiros adotou o procedimento de utilizar o lixo no controle de erosão, acreditando estar resolvendo dois problemas: o da disposição final do lixo e da erosão do solo. Um exemplo desta tendência foi aplicação desta técnica na cidade de Bauru/SP.

De acordo com Cavaguti (1995), "todo lixo urbano coletado pelos caminhões compactadores é transportado e descartado á montante da erosão. Imediatamente, dezenas de pessoas (catadores de lixo), em condições degradantes, esmiúçam este lixo á procura dos chamados recicláveis (papeis, plásticos, vasilhames, vidro e metais) separandoos e comercializando-os para sua sobrevivência, constituindo um grave problema social. Os recicláveis separados constituem aproximadamente $10 \%$ (em peso) do lixo inicial. Após ação dos catadores, o restante $90 \%$ é empurrado par o interior da erosão com trator-esteira. Quando o volume de lixo assim lançado preenche a erosão, é coberta com fina camada de solo (inferior á $30 \mathrm{~cm}$ ) e, ligeiramente compacto. Desta maneira é formada a voçoroca-lixão, cuja superfície apresenta bom aspecto visual. O "front" desse aterro recebe (ou não) uma pequena cobertura de solo".

De acordo com Souza (2001), o emprego do lixo como uma medida corretiva de feições erosivas, consiste em aterrar as feições erosivas com lixo de varias procedências (matérias de construção, domiciliar, etc.), principalmente os provenientes de matérias de construção. Iwasa \& Frendrich (1998) explica essa medida, mas alerta que, além de não controlar os processos erosivos instalados, geralmente proporciona vários tipos de contaminações (solo, animal, das águas do manancial superficial e subsuperficial), podendo também ocasionar terrenos com características geotécnicas indesejáveis.

Segundo DAEE (1990), junto com os riscos de acidentes geotécnicos, geralmente as voçorocas se tornam áreas de despejo de lixo, às vezes até como tentativa desastrosa de contenção. $O$ lixo e os lançamentos de esgoto transformam as voçorocas em focos de doenças, tornando-as ainda mais danoso ao meio ambiente urbano. 


\subsubsection{4- GABIÕES}

Segundo Machado (1995), os "gabiões" estão dentre as poucas técnicas viáveis, do ponto de vista econômico que existem hoje em nível mundial, para a prevenção e controle da erosão. A técnica de estruturas em Gabiões foi empregada com extremo sucesso em vários países, mas no Brasil é pouco conhecida e utilizada neste campo. De fato, a estrutura em gabiões reúne uma série de características técnicas e funcionais que a colocam em posição privilegiada em obras geotécnicas ou hidráulicas, no contexto urbano e rural. Em relação a essas características podemos citar como mais relevantes as seguintes: flexibilidade, resistência á tração, permeabilidade, versatilidade, praticidade, aspectos sociais, integração ambiental e durabilidade.

Alguns campos de aplicação das estruturas em Gabiões na prevenção e combate a erosão: Estruturas de sistematização e defesa hidráulica (barragens, soleiras, revestimentos de taludes de barragens, proteção de margens, espigões defletores $e$ canalização), estruturas de contenção (murros de contenção), estruturas de defesa (proteção de pilares e aterros de encontro de pontes, proteção de bueiros, escadas hidráulicas, etc.) e consolidação do solo (revestimento de encostas com rede).

Em voçorocas de pequeno porte em estágio inicial de desenvolvimento e/ou nas porções terminais de voçorocas (praticamente estabilizadas), algumas medidas podem ser adotadas como obras de pequeno porte, simples na sua concepção e execução. Neste caso, deve-se buscar o máximo de aproveitamento de materiais e de mão-de-obra disponível no local, tais como: pedras, bambus, eucaliptos. Entre estas obras destacam-se os gabiões, pequenos barramentos, pequenos aterros tipo "murundum", conforme ilustrado na Figura (2.19), DAEE, 1990. 


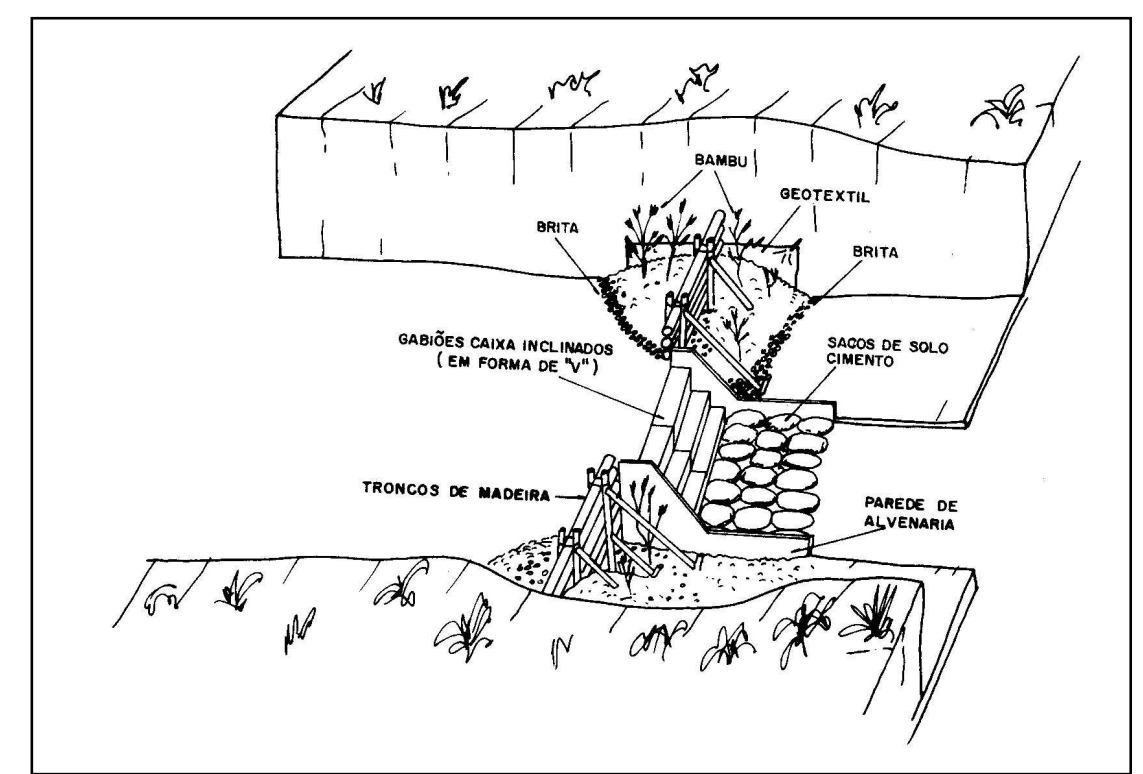

Figura 2.19: Exemplo de obras auxiliares de proteção (DAEE, 1990).

\subsubsection{5- MAPEAMENTO/ CARTOGRAFIA GEOTÉCNICA}

Há algum tempo vários trabalhos de o mapeamento/ cartografia geotécnica tem sido utilizada como medidas complementares de controle da erosão urbana. É claro obedecendo às condições locais e adotando-se uma escala adequada aos objetivos do mapeamento. Este procedimento vem mostram-se como uma importante e/ou essencial ferramenta para planejamento das áreas em termos das obras de controle executadas e uso e ocupação da área. Este assunto será retomado com mais detalhes no item 2.8.

\subsection{8- EXEMPLOS DE TÉCNICAS DE CONTROLE APLICADAS}

\section{- Com Sucesso}

A utilização de técnicas de bioengenharia tem sido aplicada para a proteção de taludes contra escorregamento, no tratamento e controle de voçorocas e na recuperação de áreas degradadas. A região da curva do Ponteio, localizada na região metropolitana de Belo Horizonte /MG, estava sofrendo com problemas de escorregamento. Neste contexto foram utilizadas com sucesso tecnologia de bioengenharia (associação de técnicas construtivas de engenharia civil com as práticas revegetacionais), que se constituem em técnicas econômicas e de grande eficiência. Os resultados esperados com o tempo são: revitalização da área degradada, redução de escorregamentos diversos, recuperação do impacto através de implementação de áreas verdes, diminuição da impermeabilização, 
diminuição da insolação direta sobre o concreto projetado, redução da erosividade da água, melhoria das condições de tráfego e atendimento parcial a demanda local por áreas de descarte de terra e materiais inertes (Silva, 2002).

Um outro exemplo de utilização das técnicas de bioengenharia, foram os taludes da indústria siderúrgica Mannesmann S.A, para o controle de processos erosivos em sulcos e proteção de taludes, foi empregado o geotêxtil biodegradável de alta densidade, conhecido como tela Vegetal ARP 430. Os efeitos verificados pelo uso dessa tela nos processos de revestimento vegetal foram descritos por Pereira, 1997: efetua o papel de "much" para germinação de sementes, reduz a evaporação da água do solo, impede a insolação direta sobre o solo, conserva a umidade por longo tempo, realiza o ancoramento de insumos para revegetação, especialmente em locais inclinados, reduz o escoamento superficial da água, evita a formação de processos erosivos, favorece a infiltração de água no solo, protege o solo contra o impacto das gotas de chuvas, reduz a transpiração dos vegetais, permite a revegetação em época de estiagem, matém os nutrientes do solo $e$ melhora imediata do aspecto visual das áreas degradadas e/ou erodidas (Coelho \& Galvão, 1998), a Figura 2.20 mostra uma vista panorâmica.

(a)

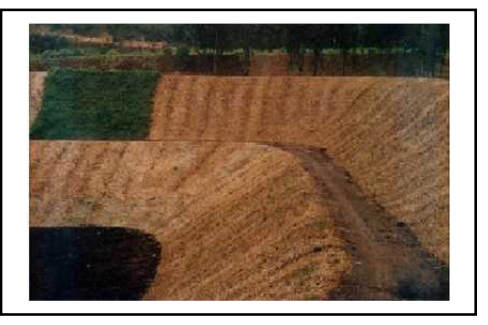

(b)

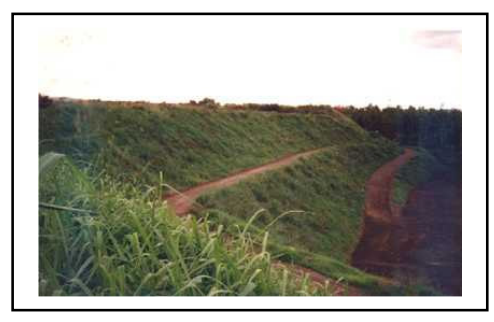

Figura 2.20: Mostra uma vista parnoramica tela ARP430, nos taludes da siderúrgica, em 15(a) e 77(b) dias respectivamente depois de implantada a tela.

Como exemplo de utilização da técnica de geotêxteis com êxito, pode-secitar o uso das chamadas bolsacreto, confeccionadas com fio de combinação poliméricas de polipropileno, polietileno de baixa densidade e plástica, moldados com solo-cimentoinjetável. Esta técnica foi empregada nas obras de recuperação de uma microbacia em Presidente Venceslau (SP), para a proteção da margem, contenção e conseqüente controle da erosão (Gagg \& Gomes, 1998).

\section{- Com Fracasso}

Carvalho \& Mortari (1995), descreveram que a contenção de voçorocas no Distrito Federal tem se baseado na construção de bacias dissipadoras (antes do inicio da mesma) $e$ barragens em gabião ou concreto. Estes autores comentam ainda que as contenções através 
de barramentos, sem a preocupação devida com o esgotamento nas ombreiras e observância dos critérios de filtro no caso de gabião não têm sido eficientes.

A utilização de lixo no controle da erosão tem sido durante décadas uma técnica corriqueira nos municípios brasileiros. Como exemplo podemos citar a cidade de Bauru/SP onde em 1987, foram construídos 4 lixões-voçorocas, que recebiam todo o lixo urbano coletado pelos caminhões compactadores na cidade. $O$ lixo acumulado contamina o ar, o solo e os recursos hídricos, gerando problemas sócios, sanitários, de saúde publica, de engenharia e de valor imobiliário. $O$ uso do lixo urbano no controle de erosão não resolve o problema da erosão e nem do lixo. Há necessidade de conscientização dos problemas conseqüentes pelas autoridades e comunidade, a fim de impedir esse tipo de degradação que reduz a qualidade e tempo de vida no município, e desenvolver projetos de recuperação dessas áreas degradadas (Cavaguti, 1995).

As técnicas de prevenção e de controle de erosões necessitam de um tratamento específico para cada caso tratado. Uma técnica utilizada com sucesso em uma determinada região, com características especifica como: solo, relevo, clima (chuva), cobertura vegetal e ação antrópica, podem representar um grande fracasso em outra região, devido o comportamento contrário de um desses agentes.

As técnicas e medidas de controle que poderão ser adotadas devem ser definidas após uma pesquisa profunda de pontos negativos e positivos de sua utilização. Estes pontos devem ser levados em consideração durante as etapas de execução do projeto, pois em muitos casos descritos na literatura, os órgãos executores não os levam em conta, causando, por exemplo, por falta de recursos, o colapso da parcela já executada do projeto.

Assim, antes de iniciar um projeto deste tipo tem que se fazer uma avaliação sócio ambiental e econômica, de posse deste e dos resultados do meio físico, pode-se estabelecer que parte do projeto possa ser executada, sem que a mesma seja posteriormente prejudicada por falta de recurso e de fenômenos do meio físico (por ex. chuvas torrenciais). 
A Tabela 2.10 foi confeccionada a partir da literatura pesquisada ao longo da revisão bibliográfica, fazendo-se uma avaliação dos métodos de controle de erosão urbana existente atualmente. Sendo que os itens a seguir foram assim avaliados:

- Técnicas: avalia se esta técnica pode ser utilizada com a finalidade de prevenção, controle ou as duas ao mesmo tempo.

- Viabilidade: avalia em termos de possibilidade de execução (muito alta, alta, moderada e baixa), permitindo concluir qual o grau de risco e melhor projeto a ser implantado.

- Custo: avalia a quantidade de dinheiro necessário para execução de cada tipo de técnica (muito alta, alta, média e baixa).

- Resultado: avalia em termos de imediato e em longo prazo, a resposta à utilização da técnica de controle do processo erosivo.

- Sofisticação: avalia em termos de baixa, média e alta uma nova tecnologia.

- Tempo de execução: avalia em termos de ano, meses e dias o tempo necessário para execução de uma obra deste tipo.

- Manutenção: avalia em termos de difícil e fácil às diversas técnicas, sendo que muitas vezes a falta ou dificuldade de execução da manutenção pode levar ao colapso de uma obra executada com sucesso. 
Tabela 2.10- Avaliação de medidas de controle de erosão é sua funcionalidade encontrada no Brasil, custo e tempo de execução e Sofisticação, baseada na análise dos trabalhos de diversos autores.

\begin{tabular}{|c|c|c|c|c|c|c|c|c|c|}
\hline \multirow{2}{*}{$\begin{array}{c}\text { Medidas de } \\
\text { controle normal } \\
\text { usadas }\end{array}$} & \multicolumn{2}{|c|}{ Técnica } & \multirow{2}{*}{ Viabilidade } & \multirow[b]{2}{*}{ Custo } & \multicolumn{2}{|c|}{ Resultado } & \multirow{2}{*}{ Sofisticação } & \multirow{2}{*}{$\begin{array}{l}\text { Tempo de } \\
\text { Execução }\end{array}$} & \multirow{2}{*}{ Manutenção } \\
\hline & Prevenção & Controle & & & Imediato & $\begin{array}{l}\text { A longo } \\
\text { prazo }\end{array}$ & & & \\
\hline Microdrenagem & $x$ & $x$ & Alta & Muito Alto & $\begin{array}{c}\text { Pouco } \\
\text { Eficiente }\end{array}$ & $\begin{array}{c}\text { Muito } \\
\text { Eficiente* }\end{array}$ & Baixa/Média & Ano & Difícil \\
\hline Macrodrenagem & $x$ & $x$ & Alta & Alto & $\begin{array}{c}\text { Muito } \\
\text { Eficiente }\end{array}$ & $\begin{array}{c}\text { Muito } \\
\text { Eficiente }\end{array}$ & Baixa & Ano & Fácil \\
\hline $\begin{array}{c}\text { Contenção de } \\
\text { taludes }\end{array}$ & $x$ & $x$ & Moderada & Médio & $\begin{array}{l}\text { Pouco } \\
\text { Eficiente }\end{array}$ & $\begin{array}{l}\text { Muito } \\
\text { Eficiente }\end{array}$ & Média/Alta & Meses & Difícil \\
\hline Revegetação & $x$ & $x$ & Muito Alta & Baixo & Pouco Efi. & Muito Efi. & Baixa & Dias & Fácil \\
\hline Aterramento & ---------- & $x$ & Moderada & Médio & Muito Efi. & Muito Efi* & Baixa & Meses & Fácil \\
\hline Barramento & -------- & $x$ & Alta & Alto/Médio & Pouco Efi & Muito Efi* & Baixa/Alta & Dias & Fácil \\
\hline Terraceamento & $x$ & $x$ & Alta & Alto/Médio & Muito Efi. & Muito Efi* & Baixa & Dias & Fácil \\
\hline $\begin{array}{l}\text { Pavimentação } \\
\text { (permeável) }\end{array}$ & $x$ & $x$ & Moderada & Alta & $\begin{array}{l}\text { Muito } \\
\text { Eficiente }\end{array}$ & $\begin{array}{l}\text { Muito } \\
\text { Eficiente }\end{array}$ & Alta/Média & Meses & Difícil \\
\hline Drenos Auxiliares & $x$ & $x$ & Moderada & Médio & Pouco Efi & Muito Efi* & Baixa & Dias & Difícil \\
\hline $\begin{array}{c}\text { Obras para feições } \\
\text { de peq. porte }\end{array}$ & & $x$ & Muito Alta & Baixo & $\begin{array}{l}\text { Pouco } \\
\text { Eficiente }\end{array}$ & $\begin{array}{l}\text { Muito } \\
\text { Eficiente }\end{array}$ & Baixa & Dias & Fácil \\
\hline Geossintéticos & $x$ & $x$ & Muito Alta & Alto/Médio & Muito Efic & Muito Efic & Alta/Médio & Dias & Fácil \\
\hline Lixo & -------- & $x$ & Alta & Baixo & Baixa Efic & Baixa Efic & Baixa & Meses & Difícil \\
\hline Gabiões & $x$ & $x$ & Muito Alta & Alto & Muito Efic & Muito efic & Alta & Dias & Fácil \\
\hline
\end{tabular}

* com manutenção

\section{X-Aplicada}

----- não aplicada 


\section{8- MAPEAMENTO GEOTÉCNICO E GEOPROCESSAMENTO PARA EROSÃO}

A erosão por apresentar-se como um fator menos destrutivo e mortal em comparação com outros eventos naturais, como escorregamento, por exemplo, acaba por tomar um lugar secundário quanto a prioridade no seu estudo e na destinação de investimentos públicos.

Os instrumentos de ações preventivas para o planejamento urbano deveriam estar baseados em Cartas Geotécnicas. Suas orientações podem ser utilizadas no plano diretor, na lei de parcelamento do solo urbano, procedendo a diretrizes para projetos de loteamento em áreas com diferentes susceptibilidades à erosão. No código de obras, a Carta Geotécnica, pode orientar soluções normativas de obras de infra-estrutura urbana. No planejamento urbano, pode auxiliar na determinação do zoneamento de uso do solo, na delimitação do perímetro urbano e no direcionamento do vetor preferencial da expansão urbana (Canil, 2001).

De acordo com Zuquette (1987) os atributos a serem levados em consideração na elaboração de uma carta de susceptibilidade à erosão são:: natureza dos materiais, relevo (grau de declividade, forma e comprimento da encosta), cobertura vegetal, fatores climáticos, ação antrópica e ação das águas e dos ventos.

Ainda segundo este autor, o objetivo da elaboração de uma carta de susceptibilidade é apresentar as áreas em ordem decrescente quanto à susceptibilidade dos materiais à erosão. Este autor frisa que isto não significa que as áreas com baixa susceptibilidade a erosão não possam apresentam problemas deste tipo, quando ocupadas desordenadamente e/ou na ocorrência de índices de erosividade muito alto. De acordo com Gomes (1997), os fenômenos erosivos se restringem as áreas onde predominam altas amplitudes e altas declividades, sendo que as principais feições erosivas mapeadas em seu trabalho de Mapeamento Geotécnico da área de Expansão Urbana da Região Sudeste do Município de Campinas são os ravinamentos e as voçorocas e estas decorrem principalmente das atividades antrópicas inadequadas.

Bachion (1997), elaborou uma carta de susceptibilidade á erosão para a região sudeste do Município de Campinas. Os atributos considerados estão relacionados aos materiais inconsolidados, substrato rochoso e escoamento superficial. Para elaboração da carta foi realizada inicialmente, uma análise para estabelecer quais os principais atributos 
do meio físico que intervinham no processo erosivo na área de estudo, sendo que os mais significativos foram: textura do solo, permeabilidade, declividade e escoamento superficial.

De acordo com Fontes (1998), para tratamento qualificado dos dados mapeados em campo e da análise das amostras coletas, podem ser utilizados programas automatizados do tipo SIG, que são ferramentas valiosas para elaboração das cartas interpretativas $e$ derivadas, como o caso da carta de susceptibilidade a erosão.

Suscetibilidade natural á erosão corresponde á possibilidade de ocorrência de um processo erosivo, conforme as condições naturais do meio físico e, portanto, pode-se dizer que a Carta de Suscetibilidade á Erosão reflete o conjunto das características naturais dos terrenos (substrato rochosos, relevo e solos), que comanda o desenvolvimento dos diferentes tipos de processos erosivos. Dentro deste contexto de suscetibilidade natural, admite-se que a susceptibilidade seja ponderada como uma variável constante ou estática no tempo e espaço, ou seja, a suscetibilidade não muda na escala de tempo humano (Canil, 2001).

A cartografia geotécnica tem a finalidade de fornecer dados sobre as propriedades das rochas, solos e água, assim como os processos e fenômenos que ocorrem neste meio, podendo ser naturais ou artificiais, com a finalidade de servir de subsídio para o planejamento urbano (GOMES, 2001).

PEJON (1992), em seu trabalho de Mapeamento geotécnico da Folha de Piracicaba $(S P)$, elaborou uma carta de potencial de risco á erosão acelerada, causada por escoamento superficial concentrado. Este autor adotou a hierarquização e atribuição de pontos aos diversos fatores intervenientes no processo erosivo, os quais incluem características dos materiais inconsolidados (textura, a estrutura, a composição, a espessura, erodibilidade, permeabilidade e infiltração), geomorfologia (declividade e comprimento da rampa) e da chuva (erosividade).

Segundo Canil (2001), a investigação e cadastramento das feições erosivas (locadas na base cartográfica constituem a carta de feições erosivas), levantamentos dos condicionantes naturais do meio físico (geologia, geomorfologia e pedologia do terreno) e das formas de uso e ocupação devem ser mapeadas e atualizadas com base em trabalhos de campo e documentação cartográfica (imagens de satélite, fotografias aéreas $e$ panorâmicas). Esta dinamização de informações deve estar sempre auxiliando nas atividades do planejamento urbano, indispensável a uma boa qualidade de vida urbana. 
Segundo Alves (1993) o Geoprocessamento é um conjunto de tecnologias voltadas à coleta e tratamento de informações espaciais para um objetivo específico. Essas atividades são executadas por sistemas denominados Sistemas de Informações Geográficas (SIG) figura 2.21.

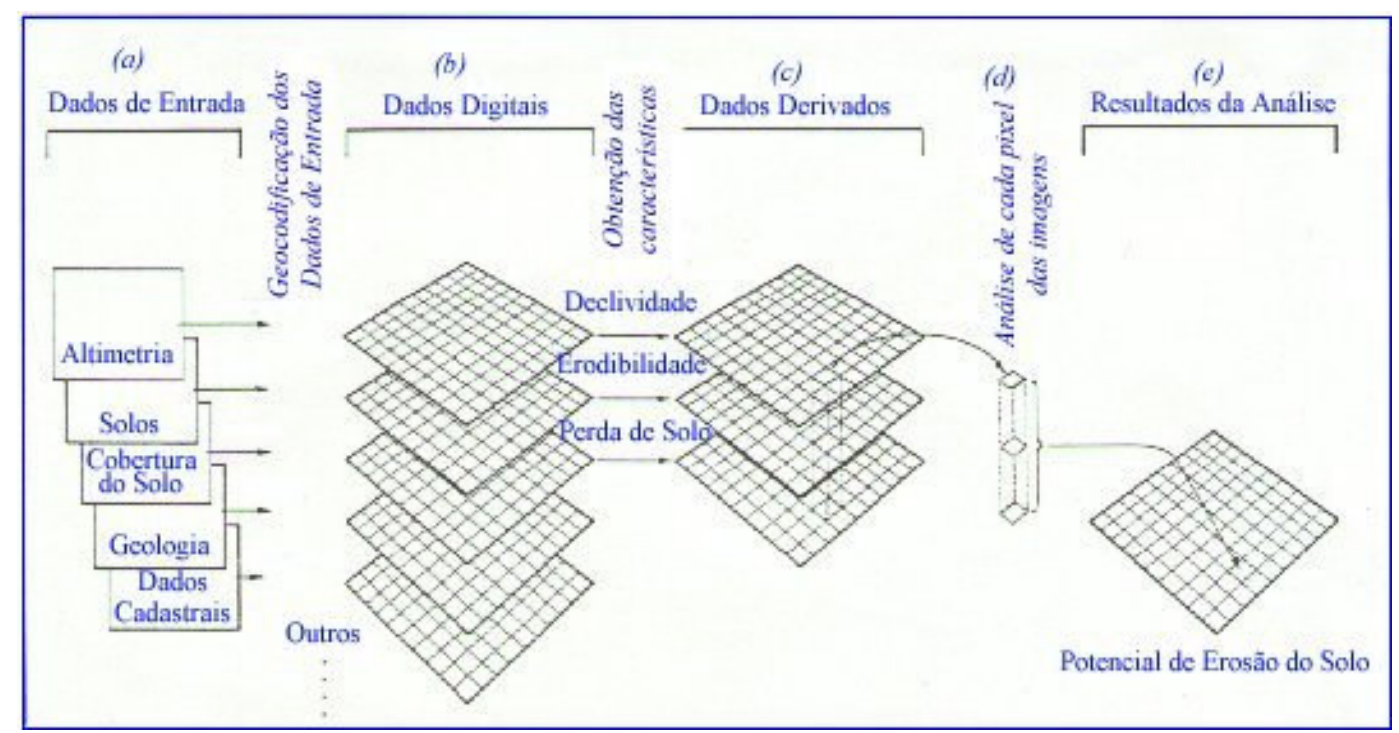

Figura 2.21 - Procedimento de análise para planejamento da erosão do solo (ARONOFF, 1991 apUd MENEGUETTE, 2000).

Grecchi e Pejon (1998) utilizaram o sistema de informações geográficas IDRISI para a confecção de um mapa de susceptibilidade à erosão do solo da região de Piracicaba (SP), considerando fatores como: pedologia, geologia, declividade e densidade hidrográfica, com o objetivo de facilitar o armazenamento e cruzamento dessas informações, e técnicas de processamento digital de imagem na obtenção do uso e ocupação do solo. Já Valério Filho \& Araújo Júnior (1995) aplicaram técnicas de geoprocessamento e modelagem para caracterização e mapeamento de áreas submetidas aos processos erosivos na Bacia do Ribeirão Bonito, tomando como base a Equação Universal de Perdas de Solo.

Fontes (1999) desenvolveu um estudo sistemático dos processos erosivos em escala 1: 5.000 , de uma área de aproximadamente de $6 \mathrm{Km} 2$, no município de Ouro Preto - $M G$. Para tanto, utilizou-se do Mapeamento Geotécnico e da Técnica de Compartimentação de Terrenos e do Sistema de Informações Geográficas IDRISI como principais ferramentas para a execução deste trabalho.

O geoprocessamento é utilizado em estudos sobre os processos erosivos para determinar o contorno (comparar ao longo do tempo a magnitude do fenômeno), criação de modelos das feições e evolução destas feições. Os principais métodos utilizados na delimitação de feições erosivas são descritos na Tabela 2.11. 
Tabela 2.11- Principais métodos utilizados na identificação de feições erosivas (Souza, 2001).

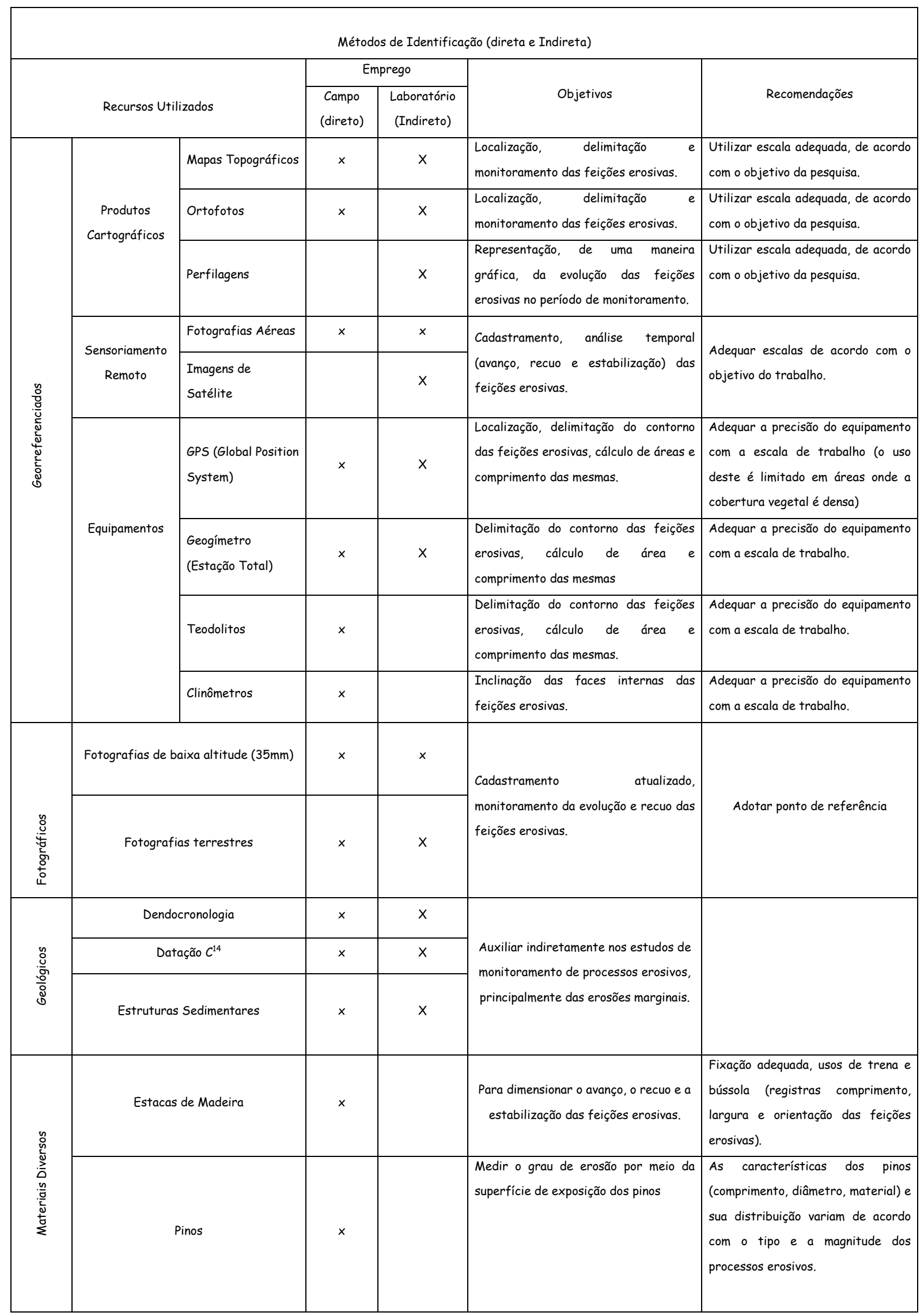




\section{9- MÉTODOS DE DETERMINAÇÃO DE VAZÃO EM EROSÃO}

Geralmente, feições erosivas do tipo de ravinas e voçorocas normalmente ocorrem em bacias hidrográficas de pequeno porte tanto na área urbana como rural. Estas bacias geralmente são desprovidas de informação pluviográficas e fluviográficas que poderiam subsidiar dados para aferição de modelos matemáticos hidrológicos, dificultando desta forma o dimensionamento de vazão de projeto de obras hidráulicas na área urbana com uma maior segurança e precisão.

Com rara exceção se encontra uma pequena bacia hidrográfica com dados registrados para uma aplicação de modelos matemáticos hidrológicos, via de regra, é necessário utilizar métodos sintéticos de determinação de vazão de projeto o que tem sido de grande utilidade para os técnicos especializados neste tipo de obra.

Os métodos sintéticos dependem da experiência do profissional em adotar valores aos seus coeficientes para obtenção de resultados satisfatórios de vazão de projeto que possam levar ao dimensionamento das estruturas hidráulicas.

Existem varias metodologias sintéticas de cálculo de vazões de pico, recomendadas e desenvolvidas para bacias hidrográficas como: Racional, I-Pai-Wu modificado (IPW), Hidrograma Unitário Sintético de Snyder (Snyder), Hidrograma Unitário Sintético Triangular do "Soil Conservation Service- SCS"-, Ven Te Chow (VTC), Hidrograma Unitário Sintético regionalizado (HUR) e Isócronas (Genovaz, 2001, DAEE, 1994, Frendrich, 1997, Righetto, 1998). Por serem os mais utilizados para cálculo de projetos de drenagem urbana, os métodos Racionais e SCS serão descritos a seguir:

\subsection{1- METÓDO RACIONAL}

Para bacias que não apresentam complexidade e que tenham até $5 \mathrm{~km}^{2}$ de área de drenagem, é usual que a vazão de projeto seja determinada pelo Método Racional. Esse método foi introduzido em 1889 e é largamente utilizado nos Estados Unidos e em outros países. Embora tenha sido freqüentemente sujeito as críticas acadêmicas por sua simplicidade, nenhum outro método foi desenvolvido dentro de um nível de aceitação geral.

Vale ressaltar os princípios básicos dessa metodologia segundo Tucci (1993): 
a) A duração da precipitação máxima do projeto é igual ao tempo de concentração da bacia. Ao considerar esta igualdade admite-seque que a bacia seja pequena para que essa condição aconteça, pois a duração é inversamente proporcional á intensidade. Em bacias pequenas, as condições mais críticas ocorrem devido a precipitação consecutivas que possuem pequena duração e grande intensidade.;

b) Adotar um coeficiente único de perdas, denominado $C$, estimado com base nas características da bacia como: solo, cobertura, tipo de ocupação, tempo de retorno $e$ intensidade de precipitação (existem vários coeficientes propostos na literatura técnica);

c) Considerar que este método não avalia o volume da cheia e a distribuição temporal das vazões.

O Método Racional, adequadamente aplicado, pode conduzir a resultados satisfatórios com projetos de drenagem urbana, que tenham estruturas hidráulicas como galerias, bueiros, etc, e ainda para estruturas hidráulicas projetadas em pequenas áreas rurais. O Método pode ser colocado sob a seguinte formula matemática:

$Q=$ C. i. $A$

Onde:

$Q=$ vazão máxima, em $\mathrm{m}^{3} / \mathrm{s}$

$C=$ coeficiente de escoamento superficial, função das características da bacia em estudo (na tabela 2.10 alguns valores típicos de projeto);

$\mathrm{i}=$ intensidade da chuva crítica, em $\mathrm{m} / \mathrm{s}$

$A$ =área da bacia de contribuição, em $\mathrm{m}^{2}$

Se os dados de A forem dados em $\mathrm{Km}^{2}$ e I em $\mathrm{mm} / \mathrm{h}$ a vazão é expressa em:

$Q=0,278$. c. i. A

De acordo com Wilken (1978) apud Genovez (2003) o método é recomendado para bacias com menos de $5 \mathrm{Km}^{2}$. O uso do método para áreas naturais grandes não é recomendado; não obstante, é satisfatório para o projeto de galerias pelo processo no qual 
se considera sub-bacias pequenas, de alguns hectares. No caso de obras hidráulica de combate à erosão urbana para bacias pequenas, o método Racional somente pode ser aplicado com maior segurança em bacias de ate $0,50 \mathrm{~km}^{2}$ (Frenfrich, 1997).

O coeficiente de Escoamento Superficial (C), também é conhecido como coeficiente de deflúvio ou coeficiente de "run-off". Este coeficiente é a relação entre o volume total precipitado e o volume total escoado superficialmente. A estimativa do coeficiente $C$ é baseada em tabelas e que tem alguns aspectos subjetivos. Nas tabelas 2.12, 2.13 e 2.14 pode-se observar algumas dessas tabelas utilizadas no método racional.

Tabela 2.12 - Coeficiente C (Chow, 1962 apud Genovez, 2003)

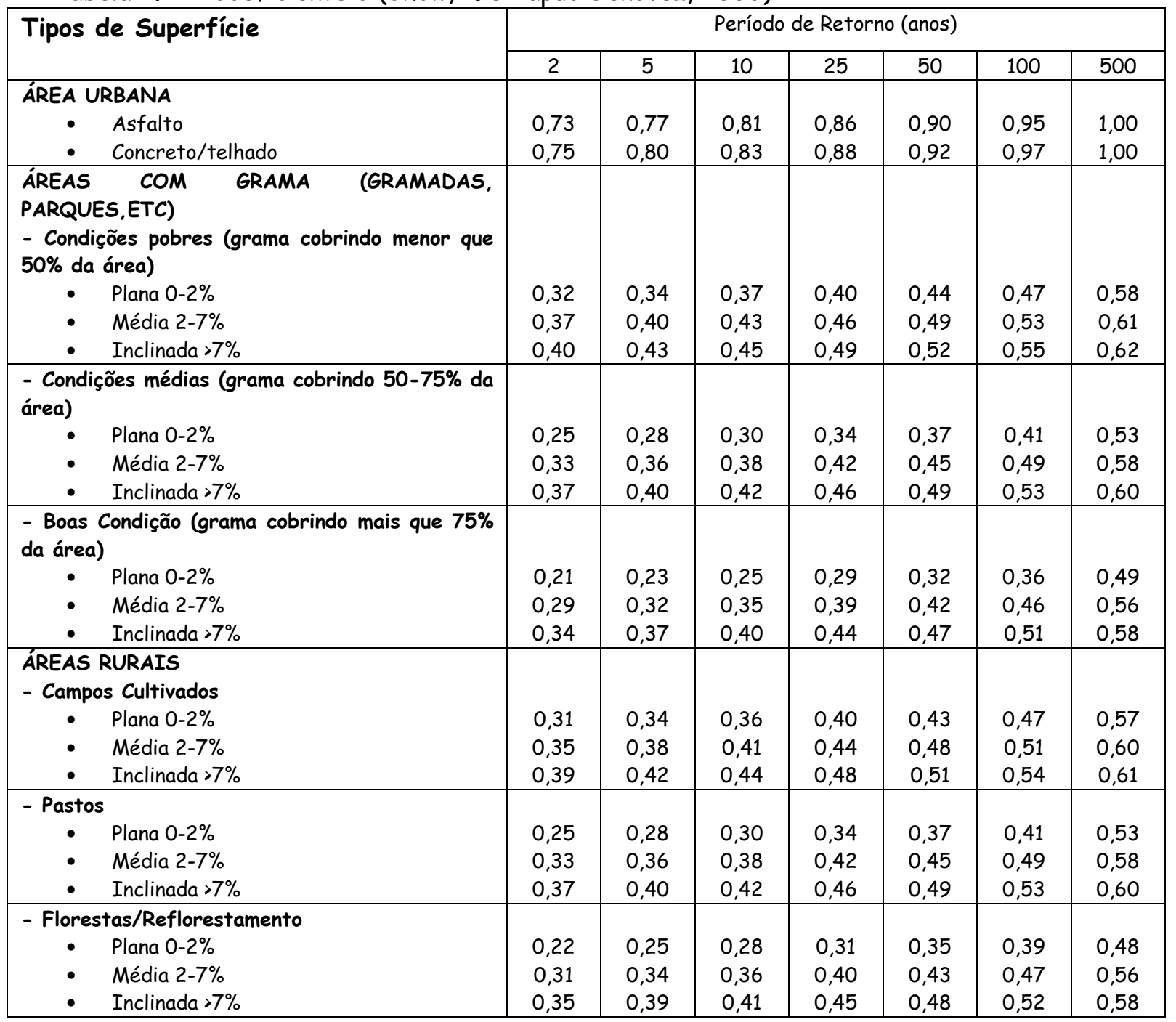


Tabela 2.13 - Coeficiente C (ASCE, 1969 apud Tucci, 1993)

\begin{tabular}{|c|c|c|}
\hline \multirow[t]{2}{*}{ Superficie } & \multicolumn{2}{|c|}{ c } \\
\hline & Intervalo & Valor esperado \\
\hline \multicolumn{3}{|l|}{ Pavimento } \\
\hline - Asfalto & $0,70-0,95$ & 0,83 \\
\hline - Concreto & $0,80-0,95$ & 0,88 \\
\hline - Calçadas & $0,75-0,85$ & 0,80 \\
\hline - telhado & $0,75-0,95$ & 0,85 \\
\hline \multicolumn{3}{|l|}{ Cobertura: grama solo arenoso } \\
\hline - plano( $2 \%)$ & $0,05-0,10$ & 0,08 \\
\hline - médio(2 a $7 \%)$ & $0,10-0,15$ & 0,13 \\
\hline - $\quad \operatorname{alta}(7 \%)$ & $0,15-0,20$ & 0,18 \\
\hline \multicolumn{3}{|l|}{ Grama, solo pesado } \\
\hline - plano & $0,13-0,17$ & 0,15 \\
\hline - médio & $0,18-0,22$ & 0,20 \\
\hline - declividade alta $(7 \%)$ & $0,25-0,35$ & 0,30 \\
\hline
\end{tabular}

Tabela 2.14 - Coeficiente C (ASCE/WEF, citado em Chow, 1962 apud Genovez, 2003)

\begin{tabular}{|c|c|}
\hline \multirow[t]{2}{*}{ Característica da Superfície } & $c$ \\
\hline & Intervalo \\
\hline \multicolumn{2}{|l|}{ Área Comercial } \\
\hline - Central & $0,70-0,95$ \\
\hline - Bairros & $0,50-0,70$ \\
\hline \multicolumn{2}{|l|}{ Área Residencial } \\
\hline - Residenciais Isoladas & $0,30-0,50$ \\
\hline - Unidades múltiplas (separadas) & $0,40-0,60$ \\
\hline - Unidades múltiplas (conjugadas) & $0,60-0,75$ \\
\hline - Subúrbio & $0,25-0,40$ \\
\hline - Área com prédio de apartamentos & $0,50-0,70$ \\
\hline \multicolumn{2}{|l|}{ Área Industrial } \\
\hline - Industrias leves & $0,50-0,80$ \\
\hline - Industrias pesadas & $0,60-0,90$ \\
\hline Parques, cemitérios & $0,10-0,25$ \\
\hline "Playgrounds" & $0,20-0,35$ \\
\hline Pátios de estrada de ferro & $0,20-0,40$ \\
\hline Áreas sem melhoramento & $0,10-0,30$ \\
\hline \multicolumn{2}{|l|}{ Ruas } \\
\hline - Pavimento asfáltica & $0,70-0,95$ \\
\hline - Pavimento de concreto & $0,80-0,95$ \\
\hline - Blocos & $0,70-0,85$ \\
\hline Passeios & $0,75-0,85$ \\
\hline Telhados & $0,75-0,95$ \\
\hline \multicolumn{2}{|l|}{ Terrenos relvados (solo arenoso) } \\
\hline - Pequena declividade (2\%) & $0,05-0,10$ \\
\hline - Declividade média (2 a 7\%) & $0,10-0,15$ \\
\hline - Forte declividade $(>7 \%)$ & $0,15-0,20$ \\
\hline \multicolumn{2}{|l|}{ Terrenos relvados (solos argilosos) } \\
\hline - Pequena declividade (2\%) & $0,15-0,20$ \\
\hline - Declividade média (2 a 7\%) & $0,20-0,25$ \\
\hline - Declividade alta $(7 \%)$ & $0,25-0,30$ \\
\hline
\end{tabular}




\section{TC- TEMPO DE CONCENTRAÇÃO}

É o tempo necessário para que a água precipitada no ponto mais distante da bacia participe na vazão no exutório da bacia.

Para o cálculo da intensidade de precipitação, deve-se adotar um tempo de duração de chuva critica. Este tempo, conhecido também como o de chuva de projeto, é adotado como sendo igual ao tempo de concentração da bacia estudada na seção de interesse. Em geral, são funções principalmente de comprimento e da declividade do talvegue, da rugosidade da superfície e da área e da declividade da bacia.

Existem vários métodos e fórmulas de cálculo de tempo de concentração, sendo que a seguir serão apresentadas as mais utilizadas (Genovez, 2003):
a) $t c=57 \cdot L^{0,77} \cdot S^{-0,385}$ (Fórmula de Kirpich, 1940)
$\left.a_{1}\right)+c=0,066\left(\frac{L}{S^{1 / 2}}\right)^{0,77}$
$\left.a_{2}\right)+c=\left(\frac{0,87 \cdot L^{3}}{H}\right)^{0,385}$

\section{Onde em a:}

tc = tempo de concentração; em min,

$L=$ comprimento do talvegue do curso de água; em $\mathrm{km}$,

$S=$ declividade do talvegue; $\mathrm{em} \mathrm{m} / \mathrm{Km}$.

\section{Onde em $a_{1}$ :}

tc = tempo de concentração; em hs,

$L=$ comprimento do talvegue do curso de água; em km,

$S=$ declividade do talvegue; $\mathrm{em} \mathrm{m} / \mathrm{m}$.

Onde em $a_{2}$ :

tc = tempo de concentração; em hs,

$H=$ diferença de nível; em $m$,

$L=$ comprimento do talvegue mais largo; $\mathrm{em} \mathrm{km}$.

A declividade é calculada dividindo a diferença de cotas $\mathrm{H}$ (em metros) entre o ponto mais distante e a saída da bacia por $L$, que é a distância do ponto mais remoto da bacia até a saída da bacia, medido ao longo do canal de drenagem. 
b) tc $=57 \cdot L^{1,155} \cdot H^{-0,385}$ (Fórmula "Califórnia Culverts Practice", 1942)

Onde:

tc = tempo de concentração; em min,

$L=$ comprimento do talvegue do curso de água; em $\mathrm{km}$,

$H=$ diferença de nível; em $\mathrm{m}$.

c) $t c=222(1,1-C) \cdot L^{0,50} \cdot S^{-0,333}$ (Fórmula do "Federal Aviation Agency", 1970) Eq.2.7 Onde $C$ é o coeficiente de escoamento superficial do método Racional usada em bacias urbanas, apesar de ter sido desenvolvida para aeroportos.

d) $t c=3504 \cdot(n \cdot L)^{0,6} \cdot S^{-0,3} \cdot I^{-0,4}$ (Fórmula da onda cinemática, 1973)

Onde:

$n=$ coeficiente de rugosidade de Manning (Tabela 2.15)

$\mathrm{I}=$ intensidade da chuva, em $\mathrm{mm} / \mathrm{hora}$

Tabela 2.15- Valores de coeficiente de Manning (Tucci,1993)

\begin{tabular}{|l|c|}
\hline \multicolumn{1}{|c|}{ Cobertura da Bacia } & $\boldsymbol{n}$ \\
\hline Asfalto suave & 0,012 \\
\hline Asfalto ou concreto & 0,014 \\
\hline Argila compactada & 0,030 \\
\hline Pouca vegetação & 0,020 \\
\hline Vegetação densa & 0,350 \\
\hline Vegetação densa e floresta & 0,400 \\
\hline
\end{tabular}

e) $t c=108,2 \cdot L^{0,8} \cdot(S / 25,4+1)^{0,7} \cdot S^{-0,5}$ (Fórmula da SCS)

Onde:

CN é o número da curva ("curve number") do método da SCS (admensional) $S=25400 / C N-254$, em $\mathrm{mm}$.

f) $t c=\frac{1000}{60} \sum \frac{L}{V}$ (Fórmula da velocidade média, 1975, 1986 -SCS)

Onde:

$L=$ comprimento de cada trecho, em $\mathrm{Km}$;

$V=$ velocidade média de cada um dos trechos, em $\mathrm{m} / \mathrm{s}$ 
Pode se usar a velocidade da tabela 2.16.

Tabela 2.16- velocidade médias aproximadas do escoamento superficial para cálculo de tc,em m/s. Texas Highway departament,1970,

\begin{tabular}{|l|c|c|c|c|}
\hline \multirow{2}{*}{ Tipo de escoamento } & \multicolumn{4}{|c|}{ Declividade em\% } \\
\cline { 2 - 5 } & $\mathbf{0 - 3}$ & $\mathbf{4 - 7}$ & $\mathbf{8}-\mathbf{1 1}$ & $\geq 12$ \\
\hline Em superfície & $0-0,5$ & $0,5-0,8$ & $0,8-1,0$ & $\geq 1,0$ \\
- Florestas & $0-0,8$ & $0,8-1,1$ & $1,1-1,3$ & $\geq 1,3$ \\
- Pastos & $0-0,9$ & $0,9-1,4$ & $1,4-1,7$ & $\geq 1,7$ \\
- Áreas Cultivadas & $0-2,6$ & $2,6-4,1$ & $4,1-5,2$ & $\geq 5,2$ \\
\hline Em canaimento & & & & $\geq 2,1$ \\
- Mal definidos & $0-0,6$ & $0,6-1,2$ & $1,2-2,1$ & \multicolumn{3}{|c|}{ Determinar usando a equação de Manning } \\
\cline { 2 - 5 } & \multicolumn{4}{|c}{} \\
\hline
\end{tabular}

g) $t c=\frac{16 \cdot L}{(1,05-0,2 \cdot p) \cdot\left(100 \cdot S_{1}\right)^{0,004}}$ (Fórmula de G. Ribeiro, citada em Garcez, 1967)Eq. 2.11

Onde:

$p=$ é a relação entre a área coberta de vegetação e área total da bacia,

$S_{1}=$ declividade média do talvegue principal em $\mathrm{m} / \mathrm{m}$

h) $t c=25,20\left(\frac{L}{S_{1}}\right)$ (Fórmula de Ven Te Chow, citada em Pinto et al.1976)

$L=$ comprimento do talvegue mais largo; em $\mathrm{km}$.

$S_{1}=$ declividade média do talvegue principal em $\mathrm{m} / \mathrm{m}$

i) $t c=5,3\left(\frac{L^{2}}{S_{1}}\right)^{1 / 3}$ (Fórmula de Picking, citada em Pinto et al. 1976)

Eq. 2.13

É difícil dizer qual a expressão que proporcionara melhor resultado para uma determinada bacia, mais o método de Kirpich tem sido um dos mais utilizados.

\section{Tr- TEMPO DE RETORNO}

A probabilidade de ocorrência de um evento hidrológico indesejável, com relação as grandes precipitações que provocam enchentes, é fundamental para avaliação e projeto de sistemas hídricos, como obras de drenagem urbana (galerias de águas pluviais, bueiros, vertedores, etc). Dentro deste contexto os tempos de retorno utilizado para obras de microdrenagem, variam normalmente de 2 a 10 anos (tabela 2.17). Podendo ser assim definidas para áreas pouco densa 
e residenciais 2 anos e para áreas comerciais, onde as perdas podem ser maiores pode se escolher 10 anos. Esse pode ser calculado através da seguinte expressão sugerida por Porto (1995):

$$
R=100 \cdot\left[1-\left(1-\frac{1}{T}\right)^{N}\right], \text { onde }:
$$

$R=\operatorname{risco}(\%)$;

$T=$ Período de retorno (anos):

$N=$ vida útil da obra (anos).

Tabela 2.17: períodos de retorno para obras de microdrenagem com diferentes tipos de ocupação (DAEE/CETESB,1980).

\begin{tabular}{|l|l|c|}
\hline Tipo de Obra & Tipo de ocupação da Área & Tempo de Retorno (Anos) \\
\hline \multirow{5}{*}{ Microdrenagem } & Residencial & 5 \\
\cline { 2 - 3 } & Comercial & 5 \\
\cline { 2 - 3 } & $\begin{array}{l}\text { Áreas com edifícios de } \\
\text { serviço público }\end{array}$ & $2-5$ \\
\cline { 2 - 3 } & \begin{tabular}{l} 
Aeroportos \\
\cline { 2 - 3 }
\end{tabular} & $\begin{array}{l}\text { Áreas comerciais e artérias } \\
\text { de tráfego }\end{array}$ \\
\hline
\end{tabular}

\subsection{2- MÉTODO U.S. SOIL CONSERVATION SERVICE}

Este método determina a descarga de uma bacia hidrográfica através do hidrograma triangular composto, que é o resultado da somatória das ordenadas de histogramas unitários simples, para cada intervalo de tempo. Foi desenvolvido pelo engenheiro Victor Mockus, em 1952, com a finalidade de se obter um hidrograma unitário sintético baseado num hidrograma adimensional (Genovez, 2003)

A determinação da vazão de pico dos hidrogramas unitários é feita utilizando a seguinte expressão:

$$
Q_{p}=\frac{2 \cdot h_{q} \cdot A}{t_{b}}
$$

onde:

$Q_{p}=$ Vazão de pico do hidrograma unitário, $\mathrm{em} \mathrm{m}^{3} / \mathrm{s}$;

$A=$ Área da bacia hidrográfica, em $\mathrm{m}^{2}$;

$h_{q}=$ altura da lâmina escoada, em m: 
$t_{b}=$ Tempo de base, em s;

\section{Cálculo da altura da lâmina escoada $\left(h_{q}\right)$}

Para a definição da relação entre chuvas e deflúvios, o método utiliza a expressão de Hawkins et al,(1985). Com uma pequena manipulação algébrica pode exprimir a relação $h_{q} / h_{p}$, o coeficiente de deflúvio. Que assim pode-se determinar a altura da lâmina escoada conforme a formula a seguir:

$$
h_{q}=h_{p} * \frac{\left(h_{p}-0,2\right)^{2}}{\left(\frac{h_{p}}{S}\right) *\left(\frac{h_{p}}{S+0,8}\right)}
$$

onde:

$h_{p}=$ altura de precipitação, em mm;

$h_{q}=$ altura da lâmina escoada, em $\mathrm{mm}$;

$\mathrm{S}=$ índice de armazenamento de água na bacia, em ( $\mathrm{mm}$ )

Para utilizar na equação 2.15 efetuar a transformação de $h_{q}$ em mm para m (multiplicando por $\left.10^{-3}\right)$

\section{Cálculo de S}

O valor de "S" é função do tipo e uso do solo e vegetação, descrito por:

Eq. 2.17

$S=254[(100 / C N)-1]$

onde: $C N=$ Curva de deflúvio (definido pela SCS) Tabela 5.5.

\section{Cálculo do tempo de base $\left(t_{b}\right)$}

$$
t_{b}=2,67 . t_{p}
$$

onde $t_{p}=$ tempo de pico, em hs

Cálculo do tempo de pico $\left(t_{p}\right)$ :

$$
t_{p}=\left(D / 2+0,6 . t_{c}\right)
$$

onde:

tp = Tempo de pico, em horas;

$D=$ duração da chuva, em horas;

tc $=$ Tempo de concentração, em horas Eq 2.4.

Para utilizar na equação 2.15 efetuar a transformação de hs para s (multiplicando por 3600) 


\section{MATERIAIS E MÉTODOS}

\section{1- ASPECTOS GERAIS}

Este trabalho envolveu basicamente três estágios de atividade: de escritório, de campo, e de laboratório, como estão descritos a seguir. A Figura 3.1 mostra o fluxograma das atividades e documentos obtidos neste trabalho, conforme descrito a seguir:

\section{2-TRABALHOS DE ESCRITÓRIO}

Os trabalhos de escritório tiveram diversas etapas, são elas: levantamento bibliográfico, produção e digitalização do mapa base, obtenção de dados preliminares, tratamento e análise das informações obtidas, produção dos produtos cartográficos geotécnicos intermediários e dos definitivos, análise da evolução das feições, técnicas de controle adotadas e redação final da pesquisa.

$\mathrm{Na}$ primeira etapa foi realizado um levantamento bibliográfico sobre estudos prévios desenvolvidos na área e de outras bibliografias atuais (sobre o tema erosão, processos erosivos e técnicas de controle e reabilitação). Assim como de mapas (1:50.000 - folha São Pedro IBGE- Instituto brasileiro de Geografia e Estatística e 1:10. 000 -folha planialtimétrica do Instituto Geográfico e Cartográfico do estado de São Paulo, ano 1979 São Pedro III) e fotografias aéreas (1962 (1:25. 000), 1972 (1:25. 000), 1978 (1:30. 000), 1988 (1:40. 000), 1995 (1:25. 000) e 2000 (1:30. 000)) e dados pluviométricos de 58 anos do SIGRH (www.sigrh.sp.gov.br). Foi realizada fotointerpretação e análise preliminar da área com relação as suas características gerais (geologia, geomorfológicas, clima e vegetação). 


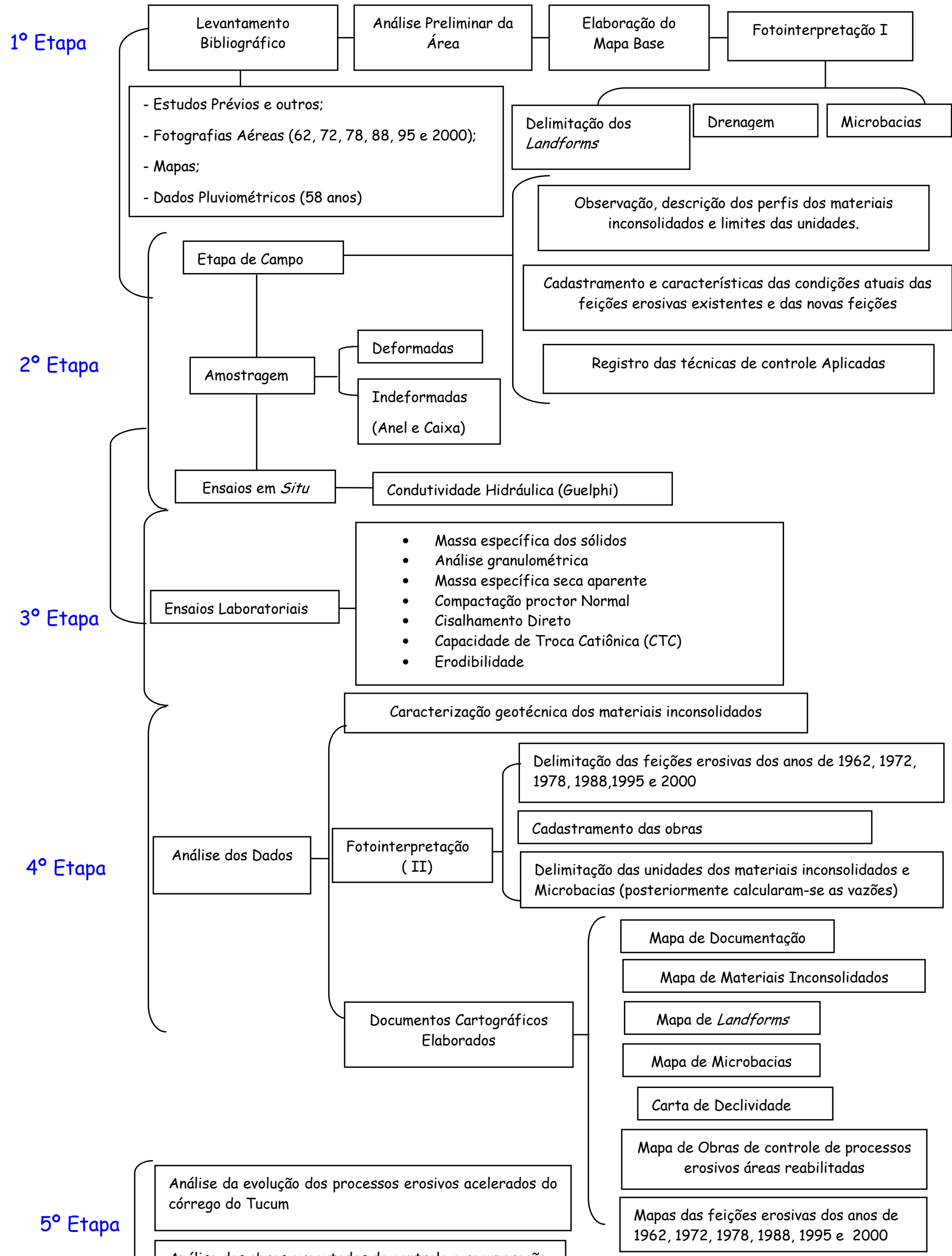

Análise das obras executadas de controle e recuperação e reabilitação

Figura 3.1- Fluxograma das atividades e documentos elaborados. 
De posse desses dados foram produzidos, a partir de fotointerpretação, os mapas preliminares de landforms (a partir da sistemática de Lollo, 1996), localização, microbacias, novos canais de drenagem e cadastramento preliminar das feições erosivas dos anos de $1962,1972,1978,1988,1995$ e 2000.

À medida que os trabalhos de campo e de laboratório foram se desenvolvendo, através das etapas de tratamento e análise das informações, foram superadas as diversas fases intermediárias de construção dos documentos cartográficos, desse modo foi obtido como produto final o conjunto cartográfico geotécnico formados 6 mapas e 1 carta.

A última etapa de escritório realizado foram acerca do desenvolvimento da redação final do texto da dissertação.

Os procedimentos utilizados para elaboração de cada um dos documentos cartográficos elaborados estão descrito nos capítulos 5 (Resultados).

\section{3-TRABALHOS DE CAMPO}

Os trabalhos de campo foram realizados com o objetivo de avaliar os resultados de fotointerpretação e caracterizar o meio físico quanto aos componentes avaliados nessa pesquisa (processos erosivos acelerados em área urbana, materiais inconsolidados $e$ landforms) além do padrão de uso e ocupação da área estudada.

Desse maneira, os materiais inconsolidados, foram caracterizados quanto a sua origem, cor, espessura, composição textural e homogeneidade. As unidades de terreno, delimitadas para o mapa de landforms, a partir dos trabalhos de campo, tiveram os seus perfis geológico-geotécnicos definidos e descritos.

Foi ainda realizado o reconhecimento geral da geologia, cadastramento das feições erosivas atuais, e das técnicas de controle e reabilitação utilizadas na área de estudo.

Foram realizadas duas etapas de amostragem dos materiais inconsolidados. Onde foram coletadas amostras deformadas: $2 \mathrm{~kg}$ aproximadamente de cada ponto para realização dos ensaios de granulometria conjunta, massa específica dos sólidos e $20 \mathrm{~kg}$ para compactação. Foram ainda coletadas amostras indeformadas do tipo anel rígidos de PVC com ponta biselada, sendo 1 anel com 7,5 cm X 4,5 cm (diâmetro/altura), para obtenção dos índices físicos, três anéis de $4,8 \mathrm{~cm}$ de diâmetro por $2,0 \mathrm{~cm}$ de altura, para os ensaios de erodibilidade e caixas $20 \mathrm{~cm} \times 20 \mathrm{~cm}$, para o ensaio de cisalhamento direto.

Durante as etapas de campo foi realizado também um monitoramento das obras de contenção e das feições presentes na área. 
Foi realizado trabalho de campo para avaliar os resultados de fotointerpretação, assim como, para definição dos perfis dos materiais inconsolidados e delimitação das unidades. Associados a esta atividade foram avaliados os usos, características das feições e registro das técnicas de controle e recuperação aplicadas, a partir de fotografias terrestres e medidas de campo.

\section{4-TRABALHOS DE LABORATÓRIO}

Nesta etapa foram caracterizados os materiais geológicos através de ensaios de laboratório de massa específica dos sólidos $-\rho_{s}$, granulometria conjunta, massa específica aparente seca $\left(\rho_{d}\right)$, ensaio de cisalhamento direto, compactação proctor normal (Nogueira 1998) e o ensaio de adsorção de azul de metileno e de erodibilidade modificados por Pejon (1992).

Nos pontos onde houve a coleta de amostras indeformadas foram obtidos outros índices físicos como massa específica seca $\left(\rho_{d}\right)$, índice de vazios $(e)$, porosidade $(n)$ e grau de saturação $\left(S_{r}\right)$.

$\mathrm{Na}$ Tabela 3.1 pode-se observar as descrições mais detalhadas de cada ensaio;

Tabela 3.1. Ensaios laboratoriais realizados.

\begin{tabular}{|c|c|c|c|}
\hline \multicolumn{2}{|r|}{ ENSAIOS } & MÉTODO & NORMA \\
\hline \multirow{6}{*}{ 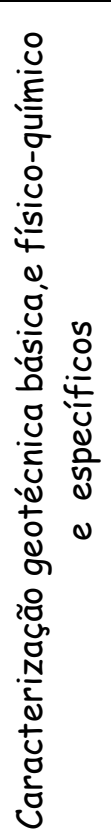 } & $\begin{array}{l}\text { Granulometria conjunta } \\
\text { com defloculante }\end{array}$ & - & $\begin{array}{l}\text { ABNT-NBR } \\
7181 / 84\end{array}$ \\
\hline & $\begin{array}{c}\text { Massa específica dos } \\
\text { sólidos }\end{array}$ & - & $\begin{array}{c}\text { ABNT- NBR } \\
6508 / 84\end{array}$ \\
\hline & $\begin{array}{l}\text { Peso específico aparente } \\
\text { seco de campo }(\gamma d c)\end{array}$ & $\begin{array}{l}\text { Método do anel } \\
\text { (Zuquette, 1993) }\end{array}$ & - \\
\hline & Cisalhamento Direto & & ASTM D3080 \\
\hline & CTC & $\begin{array}{l}\text { mancha no papel } \\
\text { filtro Pejon } 1992 \\
\text { (Modificado) }\end{array}$ & \\
\hline & $\begin{array}{l}\text { Índice de Erodibilidade } \\
\text { Perda de massa por } \\
\text { imersão e Absorção de } \\
\text { água }\end{array}$ & $\begin{array}{c}\text { Nogami \& Villibor } \\
(1979) \\
\text { Pejon } 1992\end{array}$ & - \\
\hline
\end{tabular}

O ensaio de Capacidade de troca de cátions (CTC) pelo método azul de metileno tem como objetivo a caracterização físico-química da fração fina dos materiais inconsolidados. O azul de metileno é um corante orgânico, caracteriza-se como um corante catiônico que 
em solução aquosa se dissocia em cátions e ânions. O cátion de azul de metileno substitui os cátions adsorvidos nos argilominerais, desta maneira pode-se determinar a capacidade de troca catiônica $(C T C)$, a superfície específica, o $V_{B}$ e $\circ A_{C B}$ dos argilominerais (Pejon,1992).

A obtenção do índice de erodibilidade segundo Nogami \& Villibor (1979), baseai-se em dois ensaios simples, o de absorção de água e o de perda de massa por imersão, ambos utilizam amostras indeformadas obtidas através da cravação no solo de um anel cilíndrico de PVC com dimensões de 4,8 cm de diâmetro por 2,0 cm de altura. Antes da execução dos ensaios, as amostras nos anéis são secadas naturalmente ao ar e à sombra por um período de,no mínimo 7 dias ou até que sua massa se torne constante.

Ensaio de absorção de áqua: para determinação do índice de absorção (s) é feito um gráfico do volume de água absorvido por unidade de área da base do corpo de prova (q) em função da raiz quadrada do tempo $(\sqrt{t})$.

ou seja o índice $S$ é o coeficiente angular da reta formado por estes pontos, calculado a partir da equação $s=q / \sqrt{t}$. O procedimento pode ser observado na figura 3.2.

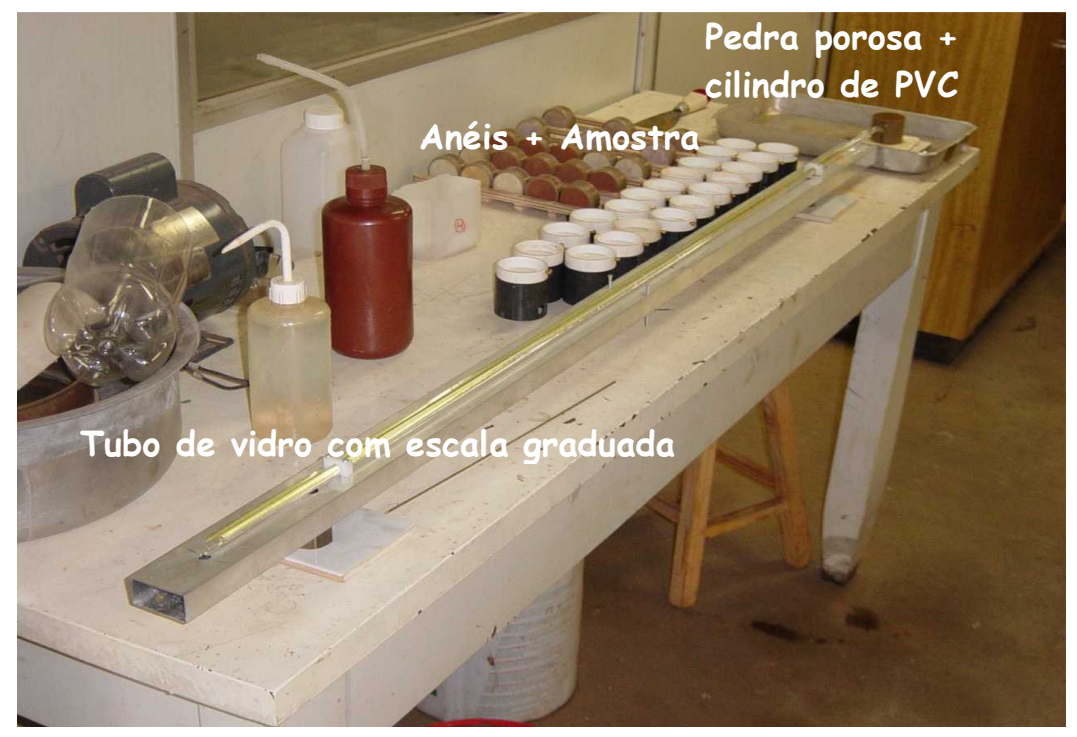

Figura 3.2- Esquema do ensaio de absorção de água.

Ensaio de perda de peso por imersão: Após o ensaio da absorção de água é feito o ensaio de perda de peso por imersão, que consiste em colocar uma pedra porosa presa na base do cilindro que contém a amostra e imerge-se o conjunto em um recipiente com água, até que o topo da amostra fique horizontal e, aproximadamente, a $2,00 \mathrm{~cm}$ do nível da água. 
Mantém-se o conjunto nesta posição até que não existam mais modificações de umidade na superfície livre do topo da amostra. Imerge-se então totalmente o conjunto e gira-se até que a superfície livre da amostra fique na vertical. Deve-se tomar cuidado para que a parte inferior da superfície livre da amostra fique a cerca de $30 \mathrm{~mm}$ do fundo do recipiente com água e dentro de um recipiente menor que permita a coleta do material desprendido desta superfície livre. Após $24 \mathrm{~h}$ determina-se a perda de peso em porcentagem do peso inicial seco da amostra $(P)$.

A partir da realização desses ensaios é feito o cálculo para determinação do índice de erodibilidade do solo proposto por Nogami \& Villibor (1979) é calculado pela seguinte expressão:

\section{$E=52 S / P$, onde:}

$S$ e $\mathrm{P}=$ valores determinados pelos ensaios de absorção de água e perda de massa por imersão;

$E<1=$ alta erodibilidade.

Já para Pejon (1992), o índice de erodibilidade proposto apresenta a seguinte expressão:

$$
E=40 S / P \text {, onde: }
$$

$S$ e $P=$ valores determinados pelos ensaios de absorção de água e perda de massa por imersão;

$E<1=$ alta erodibilidade;

$E>1$ = baixa erodibilidade:

Essa diferença apresentada no valor do coeficiente angular da reta, na expressão do índice de erodibilidade proposta pelos dois autores citados, é justificada em razão das características diferenciadas dos materiais inconsolidados analisados, que incluem, por exemplo, a profundidade de coleta, que influencia na quantidade de matéria orgânica $e$ conseqüentemente nos resultados do ensaio de perda de massa por imersão. Portanto, ao se utilizar esses índices, torna-se necessário avaliar cuidadosamente as características dos materiais inconsolidados coletados (Souza, 2001). 


\section{5- ELABORAÇÃO DOS DOCUMENTOS CARTOGRÁFICOS}

Todos os documentos cartográficos foram elaborados a partir de um mapa base, sendo que este foi confeccionado a partir de parte da folha topográfica São Pedro III, na escala 1:10 000 e de 1979, com eqüidistância entre curvas de nível de 5m.

Os mapas fundamentais elaborados neste trabalho foram o mapa de documentação, de landforms, carta de declividade, de materiais inconsolidados, de feições erosivas (1962, 1972, 1978, 1988, 1995 e 2002), de obras de controle de processos erosivos e microbacias, todos na escala 1: 5.000, e a digitalização e edição destes mapas foram feitas no software AutoCADMap ${ }^{\circledR}$.

O Mapa de Documentação contém o registro cartográfico das informações pontuais obtidas durante o mapeamento geotécnico, como os pontos de amostragem, visita, e descrição, neste mapa ainda constam à rede da malha urbana do município próxima as feições.

Já o Mapa de Landforms (Elementos) foi elaborado a partir da sistemática proposta por Lollo (1996), através de fotointerpretação de fotografias aéreas do ano de 1962, onde foram delimitados os elementos de terreno. O Mapa de Materiais Inconsolidados foi elaborado a partir de observações de campo, por tratar-se de uma área bastante modificada devido as obras de contenção das feições erosivas presentes no local desde antes de 1962, do perfil de alteração típico da área estudada e dos resultados da análise granulométrica dos materiais:

Os Mapas de feições erosivas (1962, 1972, 1978, 1988, 1995 e 2000) foram elaborados a partir da ampliação para escala 1: 5.000 das fotografias aéreas dos respectivos anos, que foram posteriormente imprimidas em escala e com auxílio de uma lupa foram identificadas e caracterizadas as feições erosivas nas diversas datas. Após este procedimento foram novamente escaneadas e digitalizadas.

O mapa de obras de controle de feições erosivas apresenta a localização das diversas obras executadas, estradas do entorno e malha urbana. Associadas ao conjunto já citado apresentam fotos destas diversas obras e seu monitoramento.

Por último o mapa de microbacias mostra uma avaliação dos diversos canais e seus divisores, dentro deste contexto apresenta-se neste mapa ainda o ponto destas obras, associadas as fotos terrestres e aéreas. 


\section{CARACTERISTICAS GERAIS DA ÁREA}

\section{1- LOCALIZAÇÃO E ACESSO}

Área de estudo esta localizada no Município de São Pedro a leste da área urbana e a margem esquerda da rodovia SP-191 (São Pedro-Charqueada). Esta compreendida entre as coordenadas UTMS 23 S (201716/203735E e 7502072/7504000N), perfazendo uma área aproximada de $2 \mathrm{~km}^{2}$ e corresponde a porção das cabeceiras do Córrego do Tucum (Figura 4.1).

O município de São Pedro dista cerca de $200 \mathrm{~km}$ da cidade de São Paulo e seu acesso pode ser feito através das rodovias Anhanguera (SP-330) até o município de Americana, seguindo-se a partir deste pela SP-304, passando pela cidade de Piracicaba. Tem seus limites com os municípios de Itirapina e Torrinha (ao Norte), Charqueada (à Leste), Santa Maria da Serra (à Oeste) e Piracicaba (ao Sul).

\section{2- HIDROLOGIA}

A cabeceira da Bacia do Córrego Tucum tem sua nascente à nordeste da cidade de São Pedro, na confluência dos bairros São Dimas, Recanto das Águas, Raia e Fazenda florestal. Este córrego tem extensão de aproximadamente $5,3 \mathrm{~km}$, com percurso no sentido norte-sudeste e desaguando no Ribeirão Araguá, que é parte da bacia do Rio Piracicaba. Apresenta drenagem que varia de média a baixa densidade, com padrões dendrítico $e$ subdendrítico, predominando vales abertos e de fundo chato.

Ellert (1980) analisando águas subterrâneas da região em questão afirma que a permeabilidade dos materiais que apresentam homogeneidade granulométrica superficial, (provenientes da Formação Pirambóia) apresentam uma alta permeabilidade, da ordem de $10^{-1}$ a $10^{-3} \mathrm{~m} / \mathrm{s}$, ocupando cerca de $80 \%$ da área, constituiem-se nas zonas de recarga pluvial das águas subterrâneas $e$, portanto em locais a serem preservados contra risco de 
contaminação ou poluição, principalmente em se tratando de região na maioria plana, com um potencial de infiltração muito grande.

\section{3- VEGETAÇÃO}

A vegetação natural encontra-se praticamente destruída, permanecendo apenas na proximidade ao córrego Tucum. As pastagens e reflorestamento (eucalipto) predominam na área. Em 1995, Francicani descreveu a necessidade de executar um levantamento das espécies vegetais que ocorrem nas Bacias do Córrego Tucum e do Espraiado, pela importância que o conhecimento destas espécies pode auxiliar na recuperação de áreas degradadas por processos erosivos.

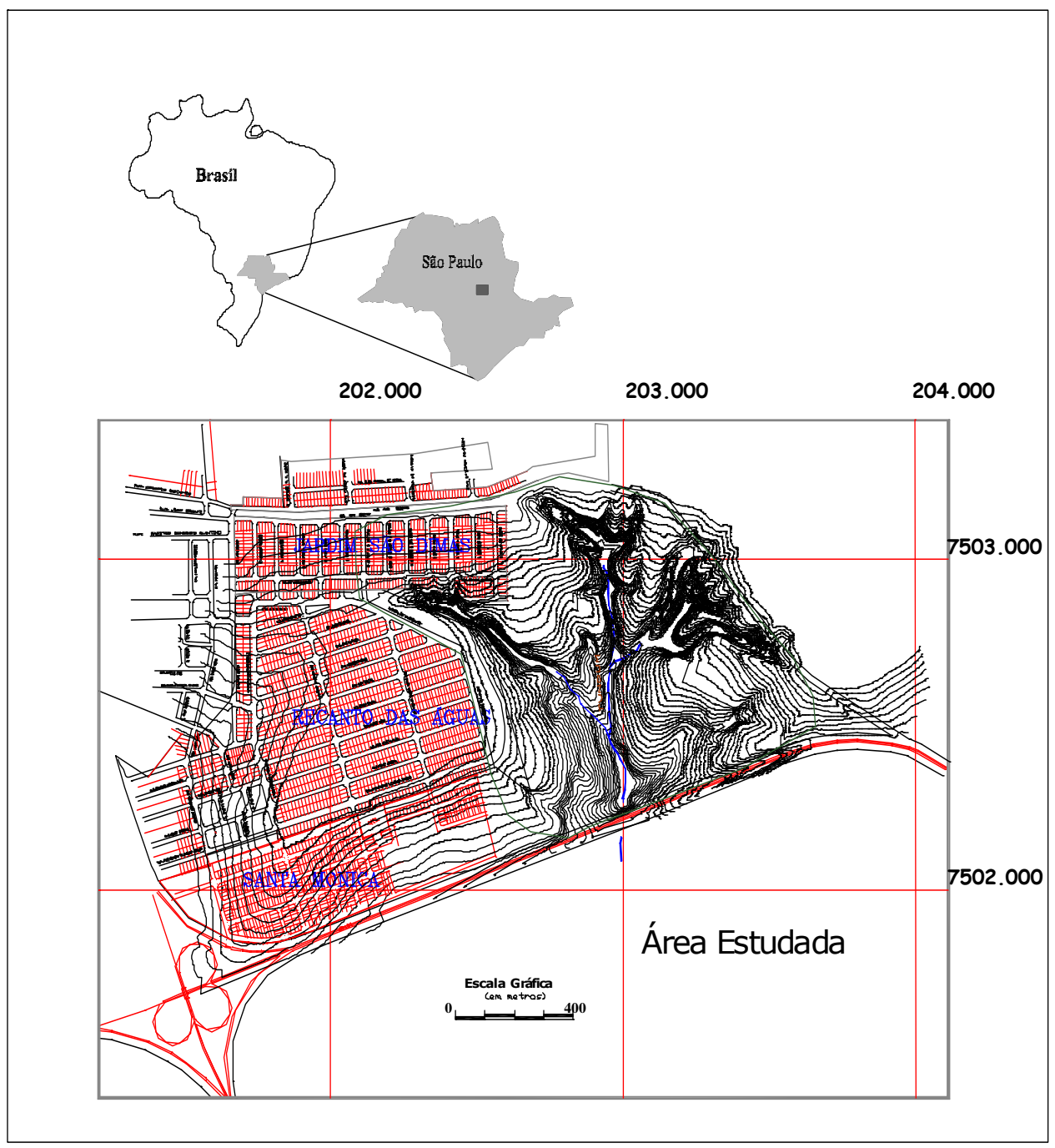

FIGURA 4.1 - Localização da cabeceira da bacia do córrego Tucum. 


\section{4- CLIMA}

O clima da região enquadra-se, segundo a classificação de Koppen (1948), como $C W a$, com médias anual variando de 1.400 a $2.227 \mathrm{~mm}$. Representando clima úmido e quente com inverno seco. As temperaturas médias do mês mais quente são de aproximadamente $28^{\circ} \mathrm{C}$, e do mês mais frio abaixo de $15^{\circ} \mathrm{C}$ (prefeituradesãopedro.com.br).

\section{5- GEOMORFOLOGIA}

Insere-se dentro da divisão geomorfológica da depressão periférica, nas proximidades das cuestas basálticas, com um relevo suave sob a forma de colinas com encosta convexas e côncavo-convexas. Na área são encontradas encostas dissecadas e patamares que são produtos do maior grau de resistência de alguns materiais. Sendo que a altitude que variam de 465 a 610 metros.

\section{6- GEOLOGIA E MATERIAIS INCONSOLIDADOS}

Seu substrato rochoso é constituído de arenitos de granulação média a fina, de diversas colorações com estratificação plano-paralela e cruzada, com diferentes tipos de cimento, pertencentes à Formação Pirambóia $(T r-J)$.

Podemos observar também alternância de lâminas com moderadas quantidades de argila e silte; e sedimentos aluvionares, constituídos por materiais muito arenosos, freqüentemente de granulometria variando de fina a média, situado próximo ao canal do córrego do Tucum.

Os materiais inconsolidados encontrados são predominantemente de origem retrabalhada e em segundo lugar residual.

Pejon (1992) realizou trabalho de mapeamento geotécnico na escala 1:100.000 da folha Piracicaba/SP, o qual teve como um dos produtos a carta de risco potencial de erosão acelerada por ravinas e voçorocas. Este autor afirma que nas proximidades da cidade de São Pedro ocorrem áreas com alto potencial a ocorrência de erosão acelerada $e$ identificou várias voçorocas de grande porte, que foram recuperadas (aterradas) e que tiveram o processo erosivo reiniciado nas primeiras chuvas subseqüentes.

Oka-Fiori (1980) em seu trabalho na área faz uma descrição geral dos materiais geológicos e da presença de fenômenos de erosão acelerada do tipo voçoroca nos arredores do município de São Pedro. Descreve ainda que na área ocorrem várias feições em evolução. 
Francicani (1995) fez uma análise da influência da estrutura e tectônica no desenvolvimento das voçorocas da região de São Pedro. Esta autora realizou levantamento geológico, identificação das feições e extração dos lineamentos, utilizando observações de campo e fotointerpretação em fotografias aéreas (escala 1:25.000). Descreveu 2 perfis pedológicos, sendo um da voçoroca do córrego do Tucum $(5 \mathrm{~m})$ e outro do Espraiado (2.40m), obteve medidas da direção das juntas e falhas na região do Município de São Pedro e Águas de São Pedro, assim como caracterizou os materiais destes perfis. A autora concluiu que os processos erosivos ocorrem preferencialmente ao longo das descontinuidades NW-SE.

Santoro (1991), fez a caracterização geotécnica dos "sedimentos" das voçorocas presentes na área próxima aos Bairros São Dimas e Recanto das Águas a partir de 10 pontos de amostragem ( 5 indeformadas e 5 deformadas). Estes sedimentos apresentaram homogeneidade granulométrica, valores de resistência ao cisalhamento ( $\phi=24 \varepsilon c=0.03$ $\mathrm{Kgf} / \mathrm{cm}^{2}$ ), índice de vazios $(0.668-0.826)$, permeabilidade em torno $10^{-3} \mathrm{~m} / \mathrm{s}$, porosidade $(41-45 \%), \gamma s\left(2.302-2.671 \mathrm{~g} / \mathrm{cm}^{3}\right)$ e quanto ao limite de consistência caracterizaram-se como não plástico.

O autor conclui então que estas características favorecem os fenômenos de erosão superficial e interna, que ocorrem em encostas convexas coletoras e que apresentam uma rápida evolução e grandes dimensões devido um fluxo de água por interceptação do lençol, mas destaca que este não parece ser o fator decisivo e nem desencadeador. Este autor descreve ainda a inexistência até então de obras de adução e captação de águas pluviais, guias e asfalto mesmo com a alta susceptibilidade do terreno a erosão. A existência de loteamentos sem infra-estrutura adequada, o desmatamento e implantação de pastagens, são outros fatores que agravam os problemas.

\section{7- PROBLEMAS AMBIENTAIS}

$\mathrm{Na}$ Cabeceira do córrego do Tucum ocorrem vários problemas ambientais como assoreamento, feições erosivas, deposição de resíduos sólidos e barreira à expansão urbana. Sendo que o processo erosivo vem sendo estudado por diversos autores como descrito a seguir:

Dentro deste contexto foram realizadas várias tentativas de controle $e$ reabilitação das feições erosivas presentes e fechamento do lixão municipal que se encontrava na área. 
IPT(1991) fez o cadastro das feições da bacia do médio Tietê, incluindo portanto - Município de São Pedro, com o objetivo de orientar para o combate a erosão. Neste trabalho fazem uma avaliação dos fenômenos erosivos, das voçorocas do bairro São Dimas e Recanto das Águas originadas pela concentração de águas pluviais, na cabeceira do Tucum. Descrevem ainda aspectos gerais em uma ficha de cadastro de erosão, como: localização, dados regionais, dados geométricos, características da área de contribuição, interação da erosão com área urbana, dinâmica das feições, medidas de combate e previsão de evolução e nível de criticidade. A partir destas informações sugerem a necessidade de um projeto de águas superficiais e subterrâneas, retaludamento, implantação de barragens de terra, sistemas de diques laterais, asfaltamento, guias e galerias a montante da feição.

IPT(1993) realizou um trabalho de diagnóstico sobre as voçorocas do córrego do Tucum, através de um estudo de campo. Avaliou as obras de contenção executadas a partir das recomendações feitas em 1991 e conclui que estas levaram em conta os fatores básicos para contenção de erosão, porém as obras foram inadequadamente projetadas $e$ executadas, provocando a reativação do processo, agravado pela falta de manutenção. Diagnosticou ainda os pontos de reativação, fez um prognóstico da tendência de evolução $e$ suas consequiências nas estruturas instaladas, habitacionais e de infra-estrutura, recomendou ações emergenciais e procedimentos de curto e médio prazo para controle e emitiu parecer técnico sobre a viabilidade de expansão urbana em áreas limítrofes.

Pejon \& Zuquette (2001) realizaram trabalhos de campo e análise em fotografias aéreas na Folha de São Pedro (escala 1:50.000), para verificar problemas ambientais erosivos existentes e compará-los com as previsões estabelecidas a partir da carta de predisposição a erosão acelerada para a área, desenvolvida por Pejon (1992). Estes autores concluíram que os resultados mostraram-se concordantes com as previsões feitas na carta e os problemas de erosão encontrados durante o inventário e o período de monitoramento.

Silva (2003) realizou mapeamento geotécnico da Bacia do córrego do Tucum, a partir de informações obtidas em campo e laboratório. Elaborou mapas e cartas geotécnicas na escala 1:10.000, como a de susceptibilidade a erosão e prognóstico ao desenvolvimento de erosões lineares. Para as cabeceiras do córrego do Tucum foram classificadas quanto a susceptibilidade de ocorrência de processos erosivos acelerados em classes alta e muito alta 


\section{1- DOCUMENTOS CARTOGRÁFICOS ELABORADOS}

Neste trabalho foram elaborados os seguintes documentos cartográficos: Mapa de Documentação, Mapa de Feições, Carta de Declividade, Mapa de Landforms, Mapa de Microbacias, Mapa de Materiais Inconsolidados e mapa de Obras de controle de feições Erosivas, todos na escala 1: 5.000 e no formato AUTOCAD MAP ${ }^{\circledast}$. Este conjunto de documentos cartográficos tem o objetivo de representar o meio físico a partir dos seus principais atributos. Para que possam ser analisados separados ou conjuntamente, indicando assim potencialidades e restrições dependendo da solicitação, que a área é submetida.

\subsection{1- MAPA BASE E DE DOCUMENTAÇÃO (ANEXO I)}

O mapa de documentação consiste no registro pontual das informações produzidas durante o mapeamento geotécnico (pontos visitados e amostrados durante o trabalho de campo) e apresenta informações relativas à topografia, a malha viária (com estradas pavimentadas e de terra), a área urbana, rede de drenagem e o limite da cabeceira da bacia em estudo.

Este mapa foi elaborado a partir de uma porção da base cartográfica formada pela folha São Pedro III (SF-23Y-A-IV-1-NO-D), na escala 1:10.000. Esta porção da folha foi georreferenciadas e colocadas em escala através do programa AUTOCAD MAP ${ }^{\circledast}$, tendo sido posteriormente digitalizadas, com curvas de nível apresentando eqüidistâncias de $5 \mathrm{~m}$.

Os dados produzidos e lançados neste mapa totalizaram 31 pontos de observação, descrição e amostragem (amostras deformadas), 10 pontos de observação, descrição $e$ amostragem (amostras indeformadas do tipo caixa) e 5 de ensaios de infiltração, sendo que alguns pontos são compostos de associações dos pontos descritos (serviram para os dois tipos de amostragem, por exemplo). A distribuição dos pontos na área foi feita na forma de três perfis indicados no mapa de documentação (Anexo I) que cortam a área com objetivo 
de observar e analisar os processos erosivos e o tipo de material geológico e inconsolidado a eles associados.

\subsection{2- MAPAS DE FEIÇÕES EROSIVAS (ANEXO II)}

O mapa das feições erosivas foi elaborado a partir do cadastramento das feições nas fotografias aéreas dos anos de 1962, 1972, 1978, 1988, 1995 e 2000. O cadastramento das feições do ano 2003 foi feito a partir de observações de campo, do estágio das feições presentes na fotografia de 2000 e de novas feições. No anexo II, encontra-se o mapa de feições do ano de 1962, além dos outros anos (1967, 1972, 1978, 1988,1995 e 2000) junto com a superposição das suas respectivas fotografias aéreas utilizada no cadastramento.

As feições erosivas foram cadastradas quanto ao tipo, suas características de evolução, localização, uso do solo e outras observações. Sendo que a identificação no mapa foi feita da seguinte maneira:

- Concentração de Sulcos (CS): pelo grande número de feições do tipo sulco, neste trabalho adotou-se para um aglomerado de sulcos (incisões no terreno de pequena profundidade) a denominação referida;

- Ravina (R): representa uma feição intermediaria entre os sulcos e a voçoroca, que pode sofrer manejo por maquina agrícola;

- Voçoroca (V): feição erosiva de grande porte, que não pode sofrer manejo por maquina agrícola;

- Voçoroca c/ ravinas (VR): voçoroca associada a ravinas;

O resultado geral do cadastro das feições erosivas identificadas para cada ano encontra-se na Tabela 5.1.

TABELA 5.1- Resultado geral do cadastro das feições erosivas

\begin{tabular}{lccccccc}
\hline $\begin{array}{l}\text { Anos } \\
\text { Feições erosivas }\end{array}$ & 1962 & 1972 & 1978 & 1988 & 1995 & 2000 & 2003 \\
\hline Concentração de sulcos & 07 & 09 & 06 & 02 & 02 & 03 & 02 \\
\hline Ravinas & 03 & 03 & 04 & 11 & 09 & 04 & 01 \\
\hline Voçorocas & 03 & 03 & 03 & 05 & 05 & 03 & 04 \\
\hline Voçorocas c/ Ravinas & 03 & 03 & 03 & 03 & 03 & 01 & - \\
\hline TOTAL & 16 & 15 & 16 & 21 & 19 & 11 & 07 \\
\hline
\end{tabular}


Em 1962 já havia três voçorocas com ravinas principais na cabeceira do córrego do Tucum, assim como associada a estas um grande número de concentrações de sulco, Ravinas e Voçorocas. Estas feições encontravam-se num intervalo de declividade de $15-75 \%$. As feições encontram-se instaladas em encostas côncava-retilineas, em geral no seu terço médio e inferior. O maior número de feições eram do tipo concentração de sulco, seguidas de voçoroca com ravinas, voçoroca e ravina que possuem 3 representantes cada uma.

Com relação aos materiais inconsolidados, as feições iniciam sulcando os materiais retrabalhados. Em seguida atingem os materiais residuais e rocha alterada. Estes são materiais com baixa resistência a erosão da Formação Pirambóia. Nos perfis dos canais principais podem ser observados os diversos materiais. No total havia 16 feições em atividade na área.

No ano de 1972 aumentou o número de concentrações de sulco de 7 para 9, mas já os outros tipos de feições mantiveram-se estáveis em número. Vale ressaltar que estas apresentaram grande evolução em termo de profundidade, comprimento e largura. Uma ravina que existia em 1962 foi recuperada provavelmente por aterramento e desapareceu. Já outra que havia sido cadastrada como concentração de sulco, depois da construção da SP-191, evoluiu para ravina.

Neste ano foram ainda cadastrada 2 novas concentrações de sulco, localizada na margem esquerda da estrada de terra São Pedro-Charqueada (fazenda florestal) e entre voçoroca com ravina do Dimas do lado esquerdo e outra voçoroca, numa encosta intermediaria.

Em 1978, as feições continuaram evoluindo em termos de largura, comprimento $e$ profundidade. Vale ressaltar que foi ampliado o número de ravina associadas a voçoroca com ravina. Um exemplo disso é o lado esquerdo do canal do Dimas. Vale ressaltar que o número de concentrações de sulco diminuiu e a de voçoroca da fazenda que tinha associada 2 concentrações de sulco, uniram-se a este e uma outra foi recuperada provavelmente por aterramento.

No ano de 1988, o numero de ravina ampliou para 4, em contrapartida algumas surgiram e outras desapareceram. Como por exemplo, a ravina da estrada SP-191, próxima a fazenda foi recuperada provavelmente por aterramento, mas surgiram novas ravinas próximo ao Bairro Recanto das Águas. Na figura 5.1 temos uma foto terrestre de 1980, 
nesta observa-se que a encosta do Recanto das Águas, apresentava-se completamente sulcada.

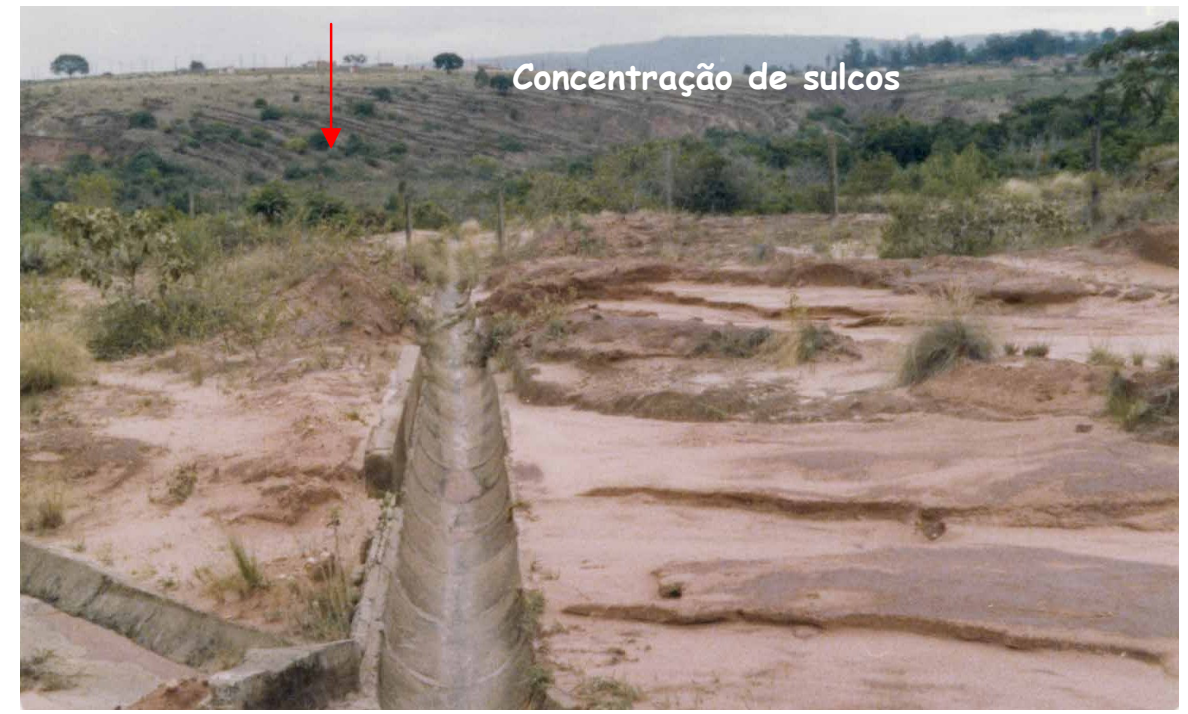

Figura 5.1 - Vista da encosta do loteamento Recanto das Águas em 1980, observar que ela esta completamente sulcada, com indicado pela seta (Oka-Fiori,1980).

Em 1988, as feições apresentam-se em seu estágio mais crítico em termos de evolução e ampliação das áreas ocupadas. Vale ressaltar que o número de ravinas subiu de 4 para 11 e o de concentração de sulco diminuiu de 6 para 2. Este fato mostra a evolução natural das feições do tipo concentração de sulco, evoluírem para ravina. Outro fato importante a ser citado é que o aumento do número de ravinas associadas ao canal do voçoroca com ravina do Dimas na sua margem esquerda, está ligado ao arruamento do bairro São Dimas. Para cada rua existe uma ravina de grande porte associada.

Em dezembro 1991 foram executadas as primeiras obras de controle, no intuíto da prefeitura de doar lotes tanto da área da av. Bandeirantes lado esquerdo do Recanto das Águas, como próximos ao prolongamento da av.bandeirantes e Rua Emydio de Arruda e na antiga estrada de Terra São Pedro-Charqueada. No ano de 1995 o número de concentração de sulco diminuiu bastante, tornando-se restrita a encosta do lado direito do Dimas, estas feições foram recuperadas pela obras de terraplanagem e terraceamento do tipo cordões de nível, mas em pontos que acumularam água romperam, como pode-se observar na Figura 5.2. 


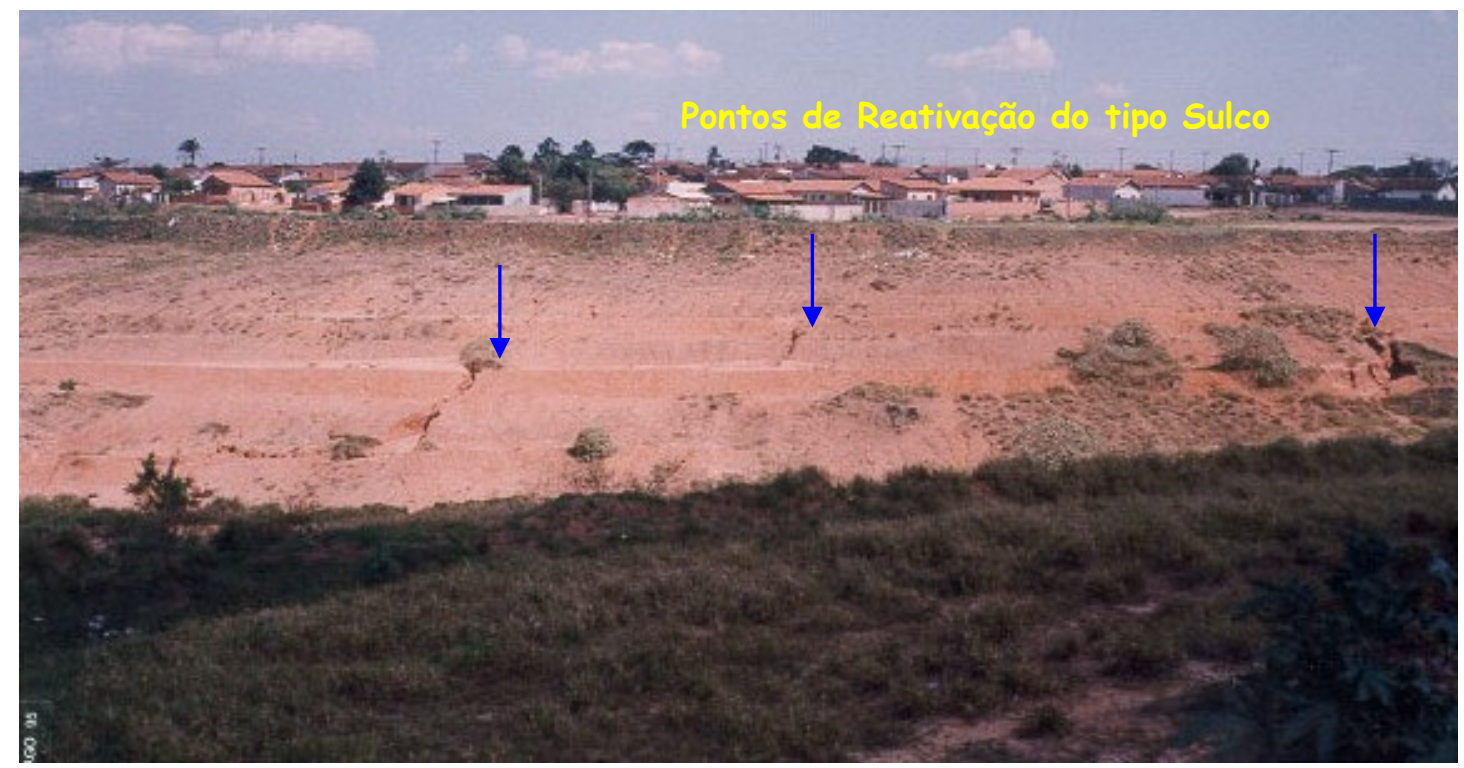

Figura 5.2- Encosta direita do Dimas, observar os cordões de nível e as reativações do tipo sulcos em alguns pontos. As setas mostram pontos de reativação.

Um fato importante a ser lembrado é a diminuição significativa da área ocupada pelas voçorocas com ravina, mais em contrapartida o número de voçoroca aumentou de 3 para 5. Estas evoluíram pela concentração de águas em alguns pontos devido os cordões nível e aumento da área ocupada pela expansão urbana. Já as ravinas diminuíram de 11 para 9 também como reflexo destas obras de controle. Comparando os anos de 1988 e 1995, verifica-se que apresentam o mesmo número total de feições, mas vale lembrar que as feições do tipo ravina e voçoroca aumentaram em número. Pois uma ravina, que foi recuperada por aterramento, volta a ser reativada, e se apresenta com atividade mais intensa e evoluindo rapidamente para uma voçoroca. Este aumento do número total de feições depois da área ser recuperada, este pode retratar os efeitos de técnicas de controle aplicadas inadequadamente $e$ as chuvas intensas que ocorreram em março deste ano. Na Figura 5.3, podemos observar os efeitos destas chuvas na área, como o rompimento do aterro por onde passava a SP-191. 


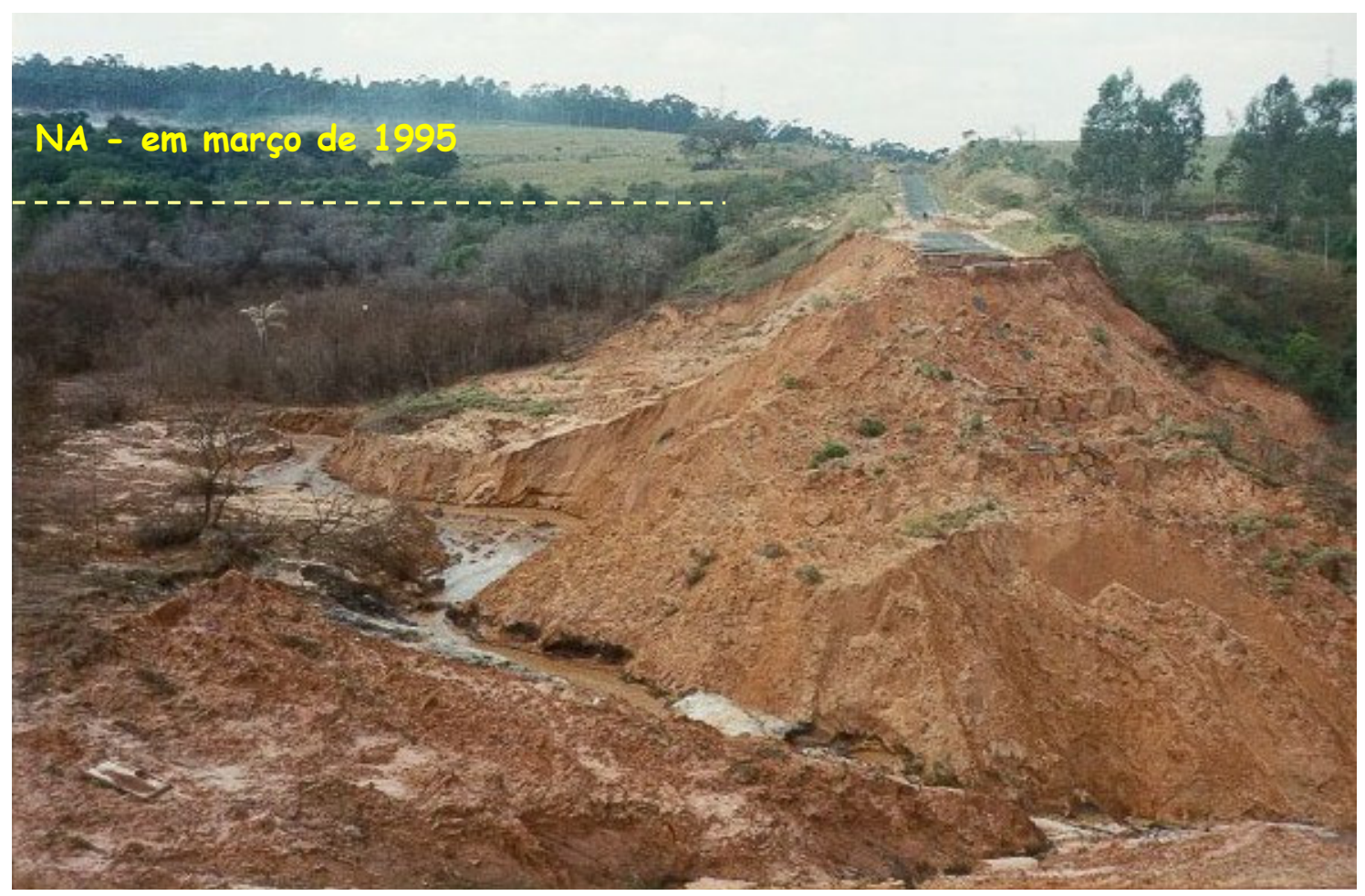

Figura 5.3- Com as chuvas de Março de 1995, o nível do córrego do Tucum subiu formando uma represa, que acabou rompendo o aterro sobre qual passava a SP-191 (Pejon e Zuquette, 2001).

O quadro em 2000 era de parcial estabilidade, tendo em vista as obras de controle executas em 1996. Isso pode ser exemplificado pelo fato que só uma das 3 voçorocas com ravina principais, que existiam desde de 1962 permanecia. O número de feições diminuiu em quase $50 \%$, de 19 para 11. Sendo que todos os tipos, sem exceção, diminuíram. Mas esta área sofre novamente com um evento de chuva forte em dezembro do mesmo ano, que causou a reativação de muitas feições que haviam sido aterradas. Como exemplo pode-se observar na Figura 5.4, a reativação da ravina aterrada na encosta do canal do Dimas provocaram risco iminente às casas que ocupavam estas encostas afetadas. 


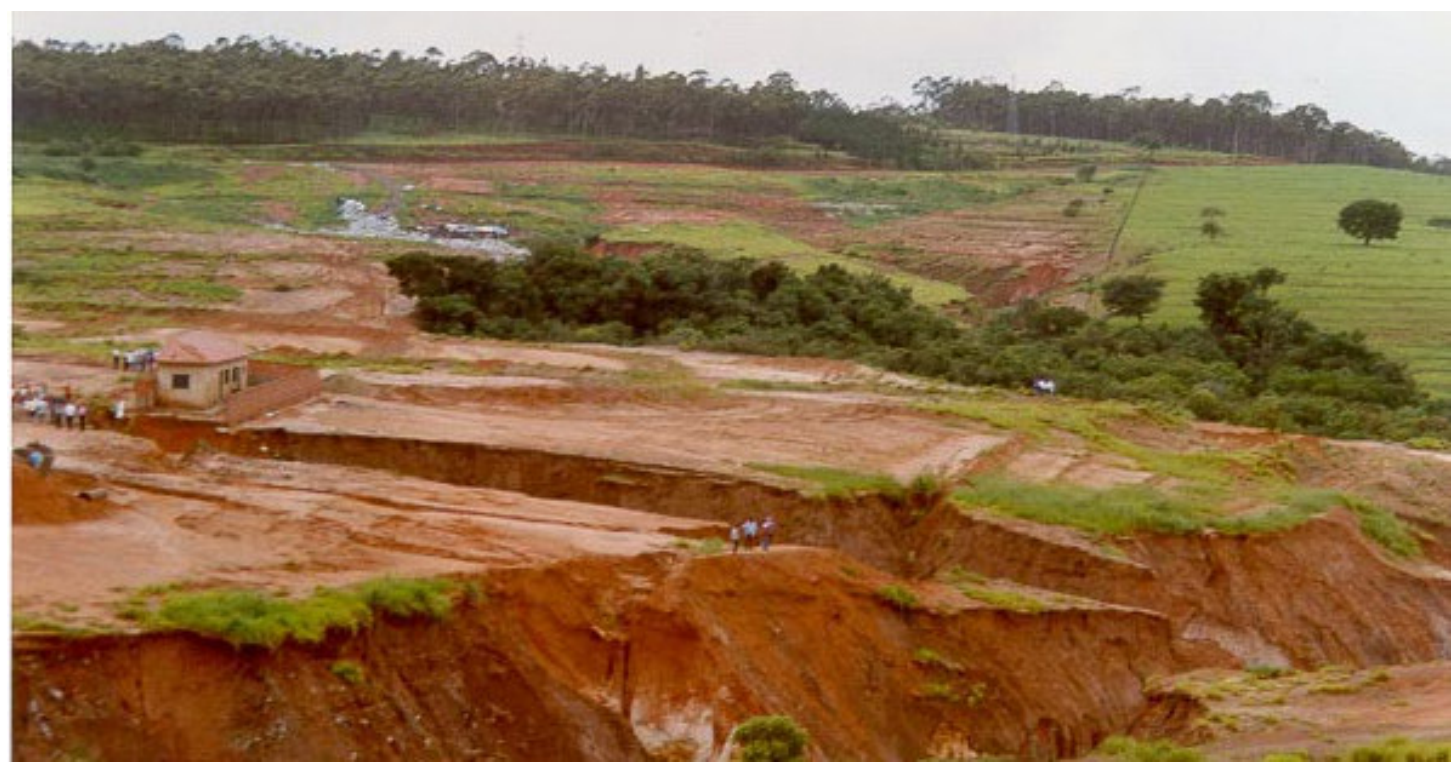

Figura 5.4- Casa afetada pela reativação da ravina aterradas na encosta do canal do Dimas. Em dezembro de 2000.

O cadastro das feições erosivas do ano de 2001, 2002 e 2003 foi elaborado a partir de trabalho de campo para confirmar as feições identificadas nas fotografias aéreas de 2000. Utilizando para isso fotografias de baixa altitude de 2001 e fotos terrestres. Foram confirmadas algumas das feições registradas em 1995 e cadastradas novas. Muitas das feições foram totalmente aterradas e não podem mais ser classificada como voçoroca com ravina. Como por exemplo, a voçoroca com ravina da favela Raia, que permanece controla até os dias atuais. Apesar de um processo de reativação devido à instabilidade da rede de águas pluviais, que já se encontra controlada. Importante observar que os cordões estão bem vegetados e estáveis (Figura 5.5).

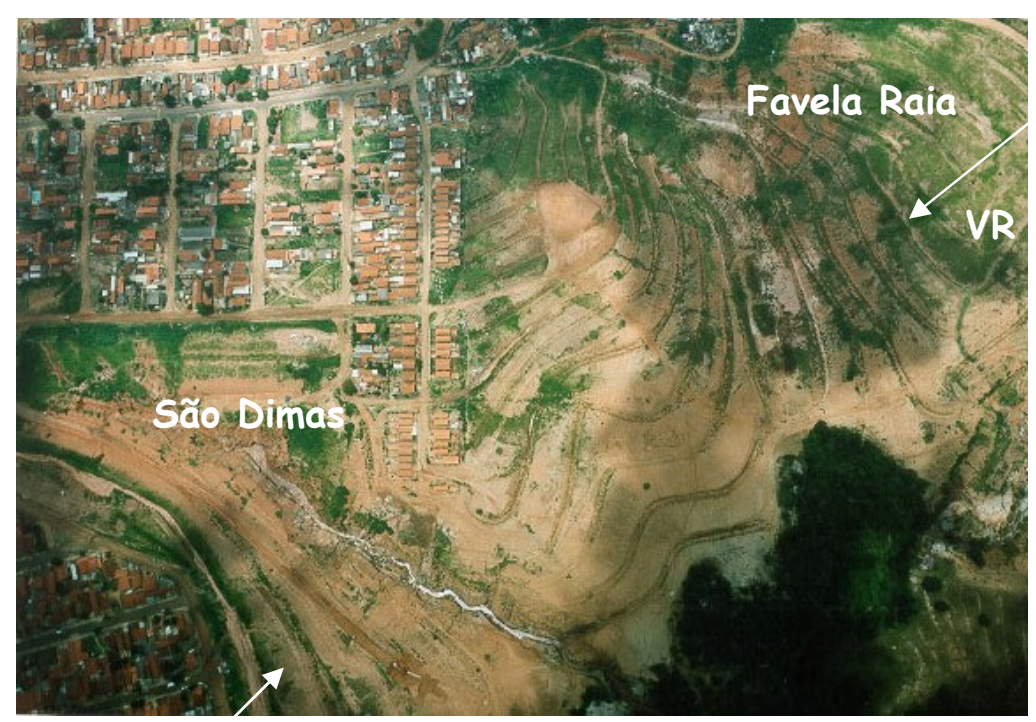

Figura 5.5: Vista aérea de baixa altitude de parte da área, observa-se que em 2001, a voçoroca com ravina, localizada na favela Raia foi controlada pela construção de cordões e encontrava-se estável. 
Outras feições foram completamente aterradas como a voçoroca do recanto das águas e a região ravina do lixão. Mas outras feições surgem ou são reativadas constantemente nos períodos mais chuvosos, por exemplo, a voçoroca do Recanto das Águas que foi aterrada, está atualmente iniciando seu processo de reativação como, mostra a figura 5.6. Onde se observa o degrau do sulcamento de terreno e deslizamento das encostas.

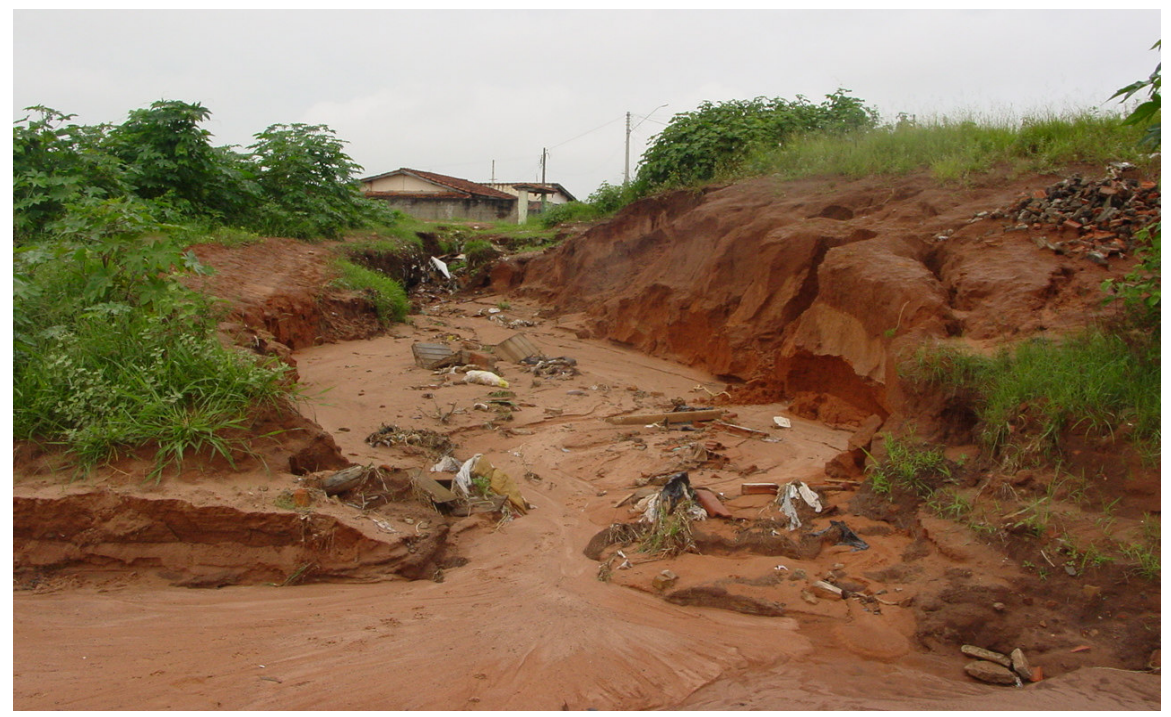

Figura 5.6- Nesta foto observa-se a reativação voçoroca do Recanto, que foi recuperada com aterramento.

Atualmente a área continua sofrendo com os processos erosivos e reativação de feições como mostra a Figura 5.7. No local se formou nova voçoroca, causada pelo rompimento das obras de controle de águas pluviais no lado direito do canal do Dimas, devido as chuvas que atingiram o município em fevereiro de 2004.

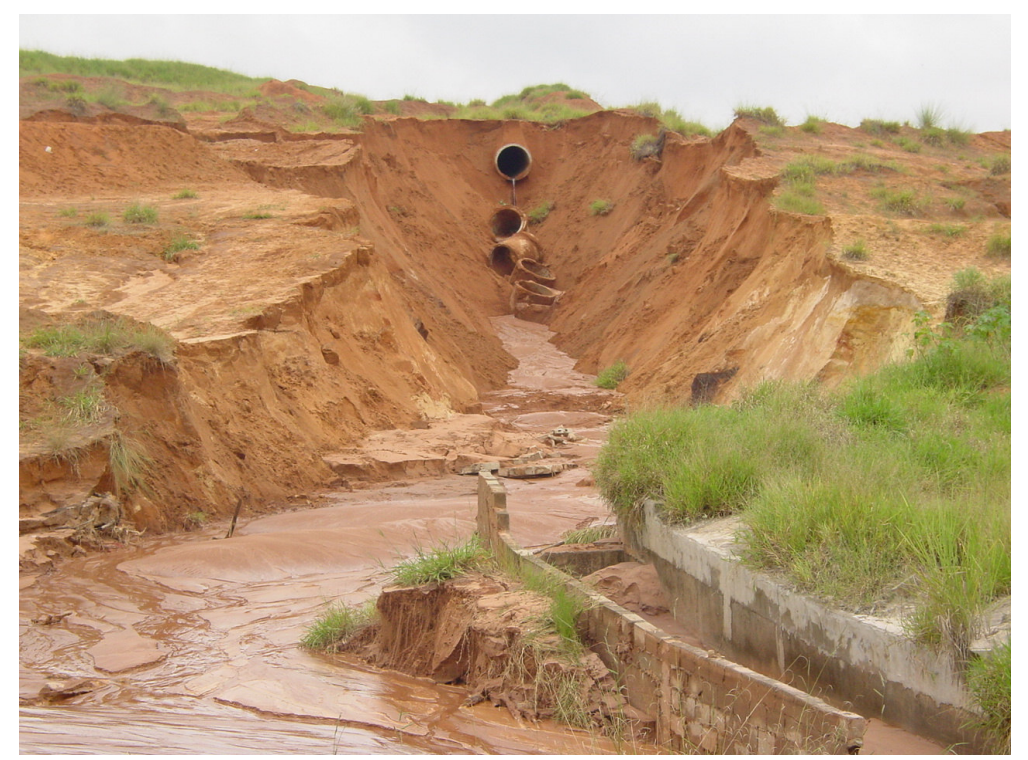

Figura 5.7- Nesta foto observa-se a nova voçoroca formada pelo rompimento da obras de águas pluviais. 


\subsection{3- CARTA DE DECLIVIDADE (ANEXO III)}

A carta de declividade contém informações acerca da variação do relevo da região expressa em porcentagem ou em graus. Neste trabalho foi confeccionada por meio computadorizado (uso de algoritmos) através de SIG's, como os programas AUTOCAD MAP ${ }^{\circledR}$, SURFER 7.0 e IDRISI 32, procedendo de acordo com as etapas a seguir:

A primeira etapa de preparação da carta de declividades iniciou-se aproveitando a digitalização das camadas do atributo topográfico realizada anteriormente para o mapa de documentação. Utilizando uma área quadrada, que foi extrapolado os limites da bacia para evitar problema na geração do modelo digital de terreno (MDT). Exportaram-se as curvas de nível e os pontos de cota (com suas respectivas elevações) utilizando-se o comando EXPORT e salvando em *.dxf (AUTOCAD R12/LT2DXF). A partir deste arquivo fez-se a conversão do arquivo de desenho vetorial para o formato *.xyz de planilha (DAT) utilizado o freeware $d x f 2 x y z 1.3$ (www.guthcad.com.au). A partir desse procedimento, os campos que compõem a tabela registram informações relativas a longitude, a latitude $e$ a altitude de cada ponto digitalizado.

$\mathrm{Na}$ segunda etapa o arquivo com extensão *.dat foi inicialmente aberto para verificar a existência de curvas com elevação zero no software Surfer $\circledast 7.00$ quefoi escolhido para geração do MNT. A partir do comando GRID/DATA, selecionou-se o arquivo *.dat. Foram testados vários métodos de interpolação, sendo o que melhor representou a topografia foi o método de Mínima Curvatura (Minimum Curvature), adotando-se um espaçamento de $1 \times 1$ metros, devido à escala adotada para este trabalho ser de detalhe. Salvou-se o arquivo no formato GS ASCII (*.grid).

A terceira etapa ocorre no Idrisi $\Theta 32$, onde importou-se o arquivo *.grid utilizando-se os comandos FILE/IMPORT/SOFTWARE/SPECIFIC/FORMATS/SRFIDRIS, criando um arquivo do programa citado. De posse deste arquivo gerou-se uma carta de declividade generalizada utilizando os comandos ANALYSIS/CONTEXT OPERATOR/SURFACE/TOPOGRAPHIC VARIABLES/ SLOPE. A partir deste novo arquivo, fez-se a reclassificação através dos comandos ANALYSIS/ DATA BASE QUERY / RECLASS. Para se obter o melhor produto para carta de declividades foi utilizado filtro moda $(3 \times 3)$ por meio do módulo de filtragem digital (digital filtering) utilizando os comando ANALYSIS/ CONTEXT OPERATOR/ FILTER. Tal 
procedimento redefiniu os pixels anteriormente presentes de forma a diminuir os resíduos, tornado assim, os intervalos de declividades mais homogêneos.

A partir da filtragem do arquivo reclassificado gerou-se a carta de declividade para a área, sendo que a definição dos intervalos das classes foi feita baseando-se na melhor representatividade dos aspectos de variação topográfica da área, obtendo-se 8 classes de declividade (Tabela 5.2).

Tabela 5.2- Classes de Declividades adotadas para a área da Bacia do Córrego Tucum.

\begin{tabular}{|c|c|c|}
\hline CLASSES DE DECLIVIDADE & PORCENTAGEM (\%) & GRAUS $\left(^{\circ}\right)$ \\
\hline 1 & $<2 \%$ & $1,15^{\circ}$ \\
\hline 2 & $2-5 \%$ & $1,15^{\circ}-2,86^{\circ}$ \\
\hline 3 & $5-10 \%$ & $2,86^{\circ}-5,71^{\circ}$ \\
\hline 4 & $10-20 \%$ & $5,71^{\circ}-11,31^{\circ}$ \\
\hline 5 & $20-30 \%$ & $11,31^{\circ}-16,70^{\circ}$ \\
\hline 6 & $30-45 \%$ & $16,70^{\circ}-24,22^{\circ}$ \\
\hline 7 & $45-75 \%$ & $24,22^{\circ}-36,87^{\circ}$ \\
\hline 8 & $>75 \%$ & $>36,87^{\circ}$ \\
\hline
\end{tabular}

A conversão do formato RST para o BMP por parte do Idrisi @ 32 permitiu que esse arquivo raster fosse reconhecido pelo AUTOCAD MAP ${ }^{\circledR}$, possibilitando assim, a sua edição final com o mesmo formato dos outros mapas e cartas (DWG). 


\subsection{4- MAPA DE MATERIAIS INCONSOLIDADOS (ANEXO IV)}

O mapa de materiais inconsolidados representa os materiais geológicos naturais que estão sobre o substrato rochoso, são ou pouco alterado. Dependendo do seu grau de detalhamento, esse produto cartográfico pode auxiliar ao usuário a avaliar o comportamento geotécnico desses materiais naturais frente diversas solicitações. Como por exemplo, os processos erosivos.

O mapa de materiais inconsolidados foi elaborado basicamente de observações de campo lançados sobre a fotografia aérea de 2000 (Figura 5.8). Assim, foi possível determinar zonas com materiais inconsolidados associados aos componentes do terreno (landforms) considerando as modificações devido às diversas obras de controle de erosão executadas.

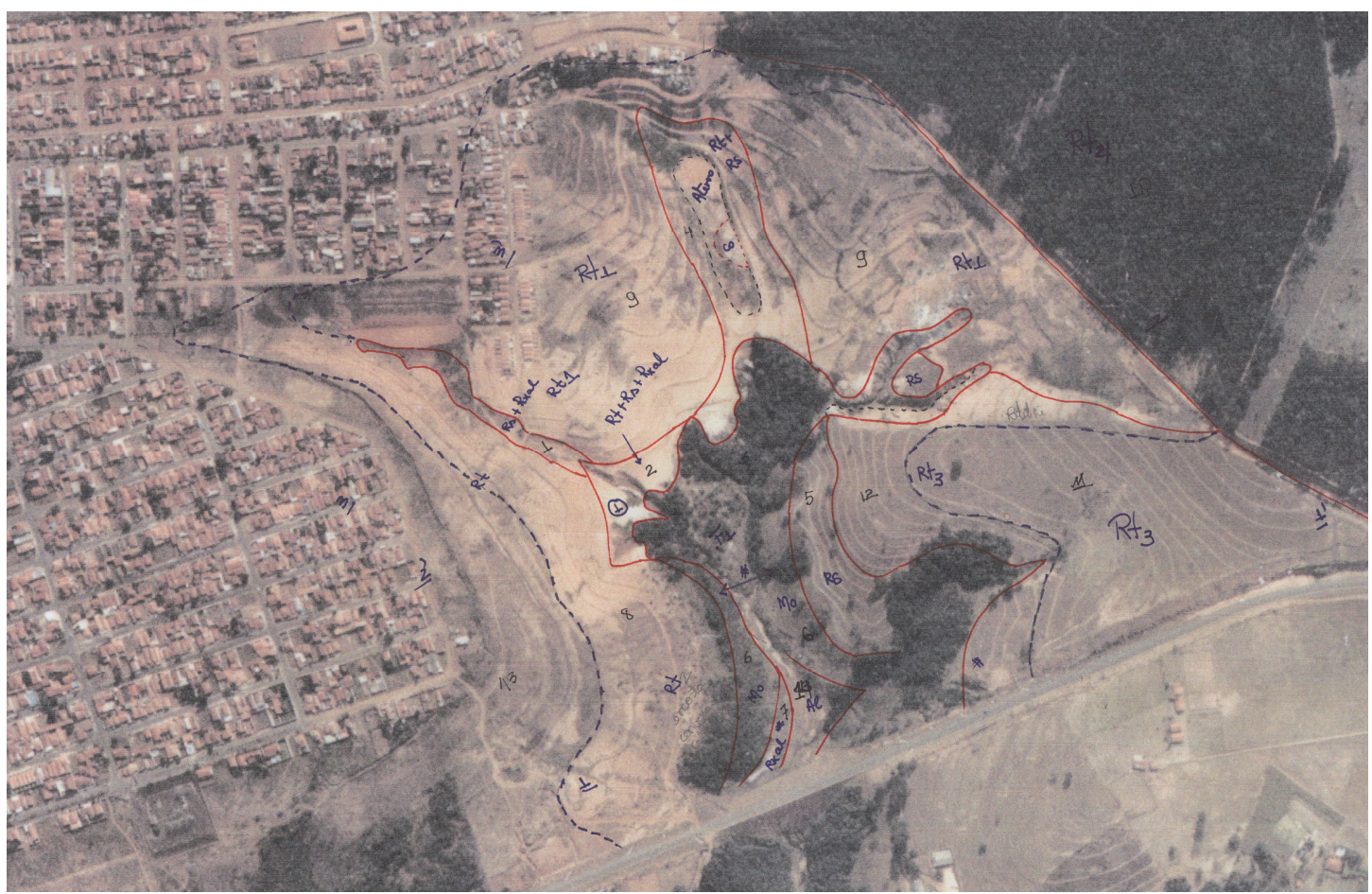

Figura 5.8- Distribuição das unidades de materiais inconsolidados em foto aérea, após serem delimitadas em campo.

Os materiais inconsolidados foram classificados a partir da gênese separando-os em residuais, retrabalhados e rocha alterada. As unidades foram definidas e delimitas a partir da associação com landforms, posição geográfica, declividade e morfologia típica das zonas de materiais. $\mathrm{Na}$ área os materiais retrabalhados representam $80 \%$ e foram divididos em função do landforms e do terreno onde afloram em de topo e de encosta. Já os materiais residuais e rocha alterada ocupam o restante, geralmente encontrados nas 
encostas dos vales e regiões onde estes materiais foram expostos devidos à escavação por máquinas para construção de cordões de nível. Vale citar que os materiais inconsolidados superficiais atualmente mudam constantemente suas características devido à intensa movimentação de máquinas para aterro das feições e reconstrução dos cordões, principalmente antes dos períodos mais chuvosos.

$\mathrm{Na}$ Tabela 5.3 encontram-se os tipos de materiais e suas características geotécnicas básicas. Existem ainda horizontes de materiais específicos como: o material $R+7$ que condiciona a transição entre materiais retrabalhados e residuais, a $L_{\text {arenosa }}$ e $L_{\text {argilosa }}$ entre o arenito alterado, e camada de materiais retrabalhado com matéria orgânica nas margens do Tucum.

Além dos ensaios de granulometria conjunta, os materiais inconsolidados também foram caracterizados a partir do ensaio de azul de metileno em função de sua capacidade de troca catiônica (CTC) total, capacidade de troca catiônica (CTC) da fração argila, superfície específica (SE) total, valor de adsorção de azul de metileno para os solos (Vb), valor de adsorção de azul de metileno para a fração argila dos solos (Acb).

Foram determinados ainda a massa específica dos sólidos $\left(\rho_{s}\right)$ e os índices físicos como massa específica seca $\left(\rho_{d}\right)$, índice de vazios (e), e porosidade (n). Além de ensaios específicos como compactação (proctor normal), erodibilidade, cisalhamento direto $e$ permeabilidade.

Os resultados dos ensaios laboratoriais (físicos e químicos) e de campo encontramse na Tabela 5.3 e 5.4 . 
Tabela 5.3: Resultados dos ensaios laboratoriais

\begin{tabular}{|c|c|c|c|c|c|c|c|c|c|c|c|c|c|c|c|c|c|c|c|c|c|}
\hline \multirow{4}{*}{ MATERIAL } & \multirow{4}{*}{ DESCRIÇÃo } & \multicolumn{10}{|c|}{ GRANULOMETRIA (\%) } & \multicolumn{2}{|c|}{$\begin{array}{l}\text { COMPACTAÇÃO } \\
\text { (PROCTOR NORMAL) }\end{array}$} & \multicolumn{8}{|c|}{ ÍNDICES FÍSICOS } \\
\hline & & \multirow{2}{*}{\multicolumn{2}{|c|}{ Argila }} & \multirow{2}{*}{\multicolumn{2}{|c|}{ Silte }} & \multicolumn{6}{|c|}{ Areia } & \multirow{3}{*}{$\begin{array}{l}\rho d \max \\
\left(\mathrm{g} / \mathrm{cm}^{3}\right)\end{array}$} & \multirow{3}{*}{$\begin{array}{l}\text { Wot } \\
(\%)\end{array}$} & \multirow{2}{*}{\multicolumn{2}{|c|}{$\begin{array}{c}\rho_{s} \\
\left(\mathrm{~g} / \mathrm{cm}^{3}\right)\end{array}$}} & \multirow{2}{*}{\multicolumn{2}{|c|}{$\begin{array}{c}\rho_{d c} \\
\left(\mathrm{~g} / \mathrm{cm}^{3}\right)\end{array}$}} & \multirow{2}{*}{\multicolumn{2}{|c|}{$e$}} & \multirow{2}{*}{\multicolumn{2}{|c|}{$\begin{array}{c}n \\
(\%)\end{array}$}} \\
\hline & & & & & & \multicolumn{2}{|c|}{ Fina } & \multicolumn{2}{|c|}{ Média } & \multicolumn{2}{|c|}{ Grossa } & & & & & & & & & & \\
\hline & & Min & $\operatorname{Max}$ & Min & $\operatorname{Max}$ & Min & $\operatorname{Max}$ & Min & $\operatorname{Max}$ & Min & $\operatorname{Max}$ & & & $\operatorname{Min}$ & $\operatorname{Max}$ & Min & Max & Min & $\operatorname{Max}$ & Min & $\operatorname{Max}$ \\
\hline R+1 & Retrabalhado topo Florestal & 15,5 & 15,9 & 1 & 3,4 & 23,5 & 27,7 & 3,0 & 6,8 & 3,0 & 6,8 & 1,95 & 10,1 & 2,61 & 2,68 & 1,69 & 1,72 & 0,54 & 0,56 & 35,2 & 36,1 \\
\hline $\mathrm{R}+2$ & Rt topo Fazenda & 7,5 & 8,5 & 1,1 & 2,6 & 25,2 & 41,1 & 48,9 & 57,2 & 2,7 & 7,8 & 1,91 & 8,5 & 2,63 & 2,67 & 1,60 & 1,77 & 0,49 & 0,67 & 32,8 & 40,1 \\
\hline$R+3$ & Rt topo Urbana & 8,3 & 10,1 & 1,4 & 2,4 & 32,4 & 38,2 & 48,3 & 53,7 & 1,7 & 3,3 & 1,89 & 9,0 & 2,59 & 2,67 & 1,63 & 1,74 & 0,52 & 0,59 & 34,0 & 37,0 \\
\hline R+4 & Rt encosta Fazenda & 5,4 & --- & 1,8 & ---- & 35,8 & ---- & 53,0 & ---- & 4,0 & -- & --- & --- & 2,71 & ---- & 1,71 & ---- & 0,59 & ---- & 37.1 & ---- \\
\hline R+5 & Rt encosta entre Dimas/Raia/Lixão & 6,7 & 12,1 & 1,2 & 4,1 & 27,5 & 36,5 & 49,3 & 55,0 & 3,7 & 5,0 & 1,933 & 9,5 & 2,61 & 2,65 & 1,61 & 1,75 & 0,54 & 0,64 & 34,9 & 39,2 \\
\hline R+6 & Rt encosta lado direito Dimas & 4,5 & 9,4 & 1,7 & 3,5 & 23,6 & 52,0 & 39,0 & 58,5 & 1,8 & 6,5 & 1,840 & 9,0 & 2,66 & 2,79 & 1,70 & 1,76 & 0,52 & 0,58 & 34,4 & 36,6 \\
\hline R+7 & Rt pedregulhoso & 8,7 & --- & 2,2 & ---- & 26,1 & ---- & 57,0 & --- & 6,0 & ---- & 1,915 & 9,5 & 2,69 & --- & 1,83 & ---- & 0,47 & --- & 32,1 & --- \\
\hline R+8 & Rt aluvião & 4,2 & ---- & 3,0 & ---- & 32,8 & ---- & 55,0 & ---- & 5,0 & --- & ---- & ---- & 2,61 & --- & 1,68 & --- & 0,56 & --- & 35,7 & --- \\
\hline Rs1 & Residual Esbranquiçado & 10,2 & 10,5 & 1,4 & 1,8 & 27,7 & 46,4 & 39,4 & 53,5 & 2,6 & 6,5 & 1,942 & 8,5 & 2,67 & 2,72 & 1,70 & 1,79 & 0,49 & 0,60 & 32,7 & 37,3 \\
\hline Rs2 & Residual amarelado & 3,3 & 3,7 & 3,9 & 4,0 & 29,4 & 36,7 & 51,0 & 55,6 & 5,0 & 7,4 & 1,803 & 9,0 & 2,69 & 2,70 & 1,76 & 1,77 & 0,52 & 0,53 & 34,3 & 34,6 \\
\hline Rs3 & Residual Rosado & 3,5 & --- & 1,8 & --- & 43,7 & --- & 50,1 & --- & 0,9 & --- & 1,87 & 6,5 & 2,69 & --- & 1,75 & --- & 0,55 & --- & 35,5 & --- \\
\hline $\mathrm{Ra} 1$ & Arenito alterada clara & 1,4 & 3,3 & 2,3 & 2,6 & 49,1 & 54,9 & 40,0 & 50,9 & 0 & 0 & ---- & ---- & 2,65 & 2,68 & 1,73 & 1,77 & 0,51 & 0,54 & 33,9 & 34,9 \\
\hline $\mathrm{Ra} 2$ & $\begin{array}{l}\text { Arenito alterada com faixas de } \\
\text { cimento escuro }\end{array}$ & 2,1 & ---- & 5,2 & ---- & 47,7 & ---- & 45,0 & --- & 0 & --- & --- & --- & 2,69 & --- & 1,75 & --- & 0,54 & --- & 34,9 & ---- \\
\hline $\mathrm{Ra} 3$ & Arenito alterada com cimento escuro & 7,7 & --- & 5,2 & --- & 47,0 & --- & 40,0 & --- & 0 & --- & 1,83 & 11,2 & 2,72 & --- & 1,79 & ---- & 0,55 & --- & 35,5 & --- \\
\hline La & Lente entre Rocha alterada & 1,8 & --- & 1,4 & --- & 31,8 & --- & 61,3 & ---- & 3,7 & ---- & 1,735 & 9,0 & 2,62 & --- & 1,65 & --- & 0,58 & --- & 33,8 & --- \\
\hline
\end{tabular}

---- apenas uma amostra coletada ou não foi coletada amostra para este ensaio

$R t=$ retrabalhado, $R s=$ Residual, $R a=$ Rocha Alterada e La= lente

$R+9=$ material não amostrado Min= mínimo e Max= maximo 
Tabela 5.4: Resultados dos ensaios laboratoriais e em in situ

\begin{tabular}{|c|c|c|c|c|c|c|c|c|c|c|c|c|c|c|}
\hline \multirow[t]{3}{*}{ MATERIAL } & \multicolumn{8}{|c|}{ AZUL DE METILENO } & \multicolumn{3}{|c|}{ ERODIBILIDADE } & \multicolumn{2}{|c|}{$\begin{array}{l}\text { CISALHAMENTO } \\
\text { DIRETO }\end{array}$} & \multirow{3}{*}{$\begin{array}{c}\text { COEFICIENTE DE } \\
\text { PERMEBILIDADE } \\
\text { GUELPF } \\
(\mathrm{CM} / \mathrm{s})\end{array}$} \\
\hline & \multicolumn{2}{|c|}{$\begin{array}{c}\mathrm{Vb} \\
\text { (g/100g solo) }\end{array}$} & \multicolumn{2}{|c|}{$\begin{array}{c}\text { Acb } \\
\text { (g/100g Argila) }\end{array}$} & \multicolumn{2}{|c|}{$\begin{array}{c}C T C \\
(\mathrm{meq} / 100 \mathrm{~g}) \text { solo }\end{array}$} & \multicolumn{2}{|c|}{$\begin{array}{l}\text { Superfície } \\
\text { Especifica. } \\
\left(\mathrm{m}^{2} / \mathrm{g} \text { argila) }\right.\end{array}$} & \multirow[t]{2}{*}{$\begin{array}{c}\text { Pm(\%) } \\
\begin{array}{c}\text { (Indice de perda } \\
\text { por Imersão) }\end{array} \\
\text { Média }\end{array}$} & \multirow{2}{*}{$\begin{array}{l}\text { Sm } \\
\text { Média }\end{array}$} & \multirow{2}{*}{$\begin{array}{c}\text { E40 } \\
\text { (Índice de } \\
\text { Erodibilidade- } \\
\text { Pejon, 1992) } \\
\text { Média } \\
\end{array}$} & \multirow[t]{2}{*}{$\phi$} & \multirow[t]{2}{*}{$\underset{(\mathrm{KPa})}{C}$} & \\
\hline & Min & Max & Min & Max & Min & Max & Min & Max & & & & & & \\
\hline $\mathrm{R}+1$ & 0,2595 & 0,5319 & 1,6067 & 3,4316 & 0,7986 & 1,6627 & 6,2504 & 13,0139 & 69,86 & 1,4209 & 0,80 & & & ------ \\
\hline$R+2$ & 0,1254 & 0,3035 & 1,6707 & 3,8907 & 0,4191 & 0,9746 & 3,2799 & 7,6284 & 67,54 & 1,9335 & 1,03 & & & ------- \\
\hline$R+3$ & 0,2176 & 0,3142 & 2,3154 & 3,3551 & 0,6804 & 6,8705 & 5,3251 & 7,6864 & 74,10 & 1,7976 & 0,97 & & & $2,4 \times 10^{-4}$ \\
\hline $\mathrm{R}+4$ & 0,1267 & ---- & 2,3461 & ----- & 0,3960 & ----- & 3,0997 & ------ & 13,16 & 2,0938 & 6,36 & $25^{\circ}$ & 11 & ------ \\
\hline$R+5$ & 0,1299 & 0,4909 & 1,5461 & 4,0580 & 0,406 & 1,5346 & 3,1775 & 12,0115 & 72,14 & 1,6535 & 0,93 & & & - ---- \\
\hline$R+6$ & 0,1336 & 0,2221 & 0,7151 & 2,969 & 0,6026 & 0,6944 & 3,2688 & 5,4349 & 77,35 & 1,8215 & 0,94 & & & $1,93 \times 10^{-3}$ \\
\hline $\mathrm{R}+7$ & 0,2256 & ---- & 0,5934 & ----- & 0,7053 & ----- & 5,5203 & ------ & 74,16 & 2,2046 & 1,19 & & & ------ \\
\hline$R+8$ & 0,0694 & ---- & 1,4865 & ----- & 0,1952 & ----- & 1,5275 & ---- & 24,27 & 1,7171 & 2,83 & & & ------ \\
\hline Rs1 & 0,2258 & 0,4259 & 2,2140 & 4,056 & 0,7059 & 1,3313 & 5,5252 & 10,420 & 51,02 & 1,5398 & 1,44 & & & ------ \\
\hline Rs2 & 0,0986 & 0,0941 & 2,6640 & 2,8518 & 0,2942 & 0,3081 & 2,3025 & 2,4117 & 69,05 & 1,7584 & 1,01 & $25^{\circ}$ & 18 & -.--- \\
\hline Rs3 & 0,2461 & ---- & 7,0307 & ----- & 0,7692 & ---- & 2,4117 & ---- & 79,95 & 0,9562 & 0,48 & $23^{\circ}$ & 16,4 & $2,31 \times 10^{-3}$ \\
\hline $\mathrm{Ra} 1$ & 0,0318 & 0,1064 & 2,2704 & 3,2232 & 0,0994 & 0,3325 & 0,7777 & 2,6024 & 74,81 & 1,2359 & 0,66 & & & ----- \\
\hline $\mathrm{Ra} 2$ & 0,1924 & --- & 9,1640 & ---- & 0,6016 & ---- & 4,7084 & ----- & 56,25 & 0,1629 & 0,15 & & & ----- \\
\hline $\mathrm{Ra} 3$ & 0,2256 & ---- & 3,6943 & ----- & 0,8892 & --- & 6,9598 & ---- & 79,96 & 0,9075 & 0,45 & & & ---- \\
\hline La & 0,0648 & ---- & 3,5982 & ---- & 0,2025 & --- & 4,5847 & ------ & 80,68 & 1,0584 & 0,52 & & & ---- \\
\hline
\end{tabular}

--- apenas uma amostra coletada ou não foi coletada amostra para este ensaio

Min= mínimo e Max $=$ maximo 
A seguir serão descritas as principais características das unidades mapeadas, sendo que esta pode representar um material ou um conjunto destes:

Unidade 1 - tem no topo os materiais Rs2 e Rs3, com espessura entre de 1 e $3 \mathrm{~m}$. Sotopostos a estes encontra-se o material Ra1, com espessura variando ao longo do canal de $0,5 \mathrm{~m}$ a $2 \mathrm{~m}$. Logo abaixo deste ocorre a rocha alterada com faixas de cimento escuro (material Ra2) espessura variando de 1 a 2 metros. Estes materiais recobrem material Ra3 (rocha alterada com cimento escuro), com estratificação plano-paralela, com lentes de material $L_{\text {arenosa }} e L_{\text {argilosa }} q u e$ controla o fundo do vale. Em parte, esta unidade encontra-se recoberta por materiais retrabalhados escorregados das unidades 8 e 9 , que serão posteriormente descritas. Na figura 5.9 (a), observa-se a distribuição espacial dos materiais que compõem a unidade 1, na encosta direita do canal do Dimas e recobertos pela unidade 8. Já na figura 5.9(b), observa-se detalhe da lente arenosa no perfil de alteração e sua característica de desmonte fácil pelo processo,tornando os pacotes acima mais instáveis.

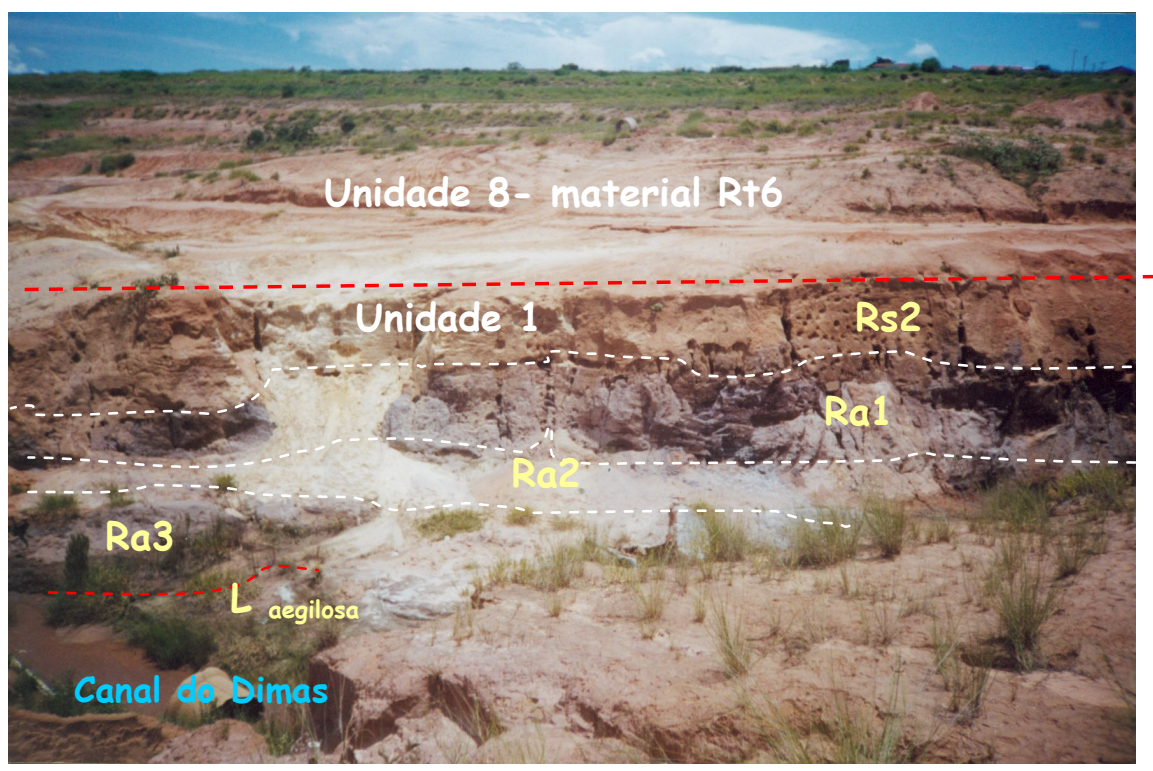

(b)

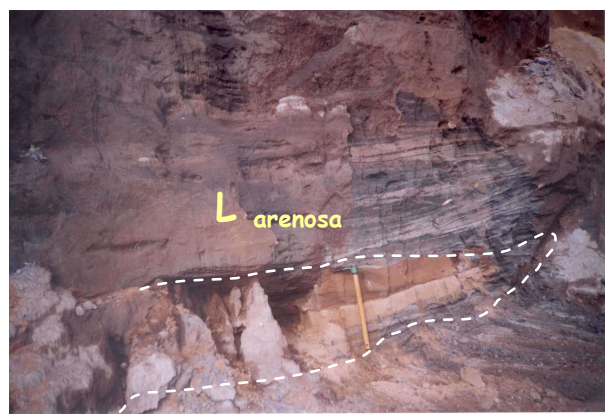

Figura 5.9: (a) Tipos de Materiais inconsolidados representativos das unidades 1 e 8, Feição erosiva do Dimas (Ponto P2-06) e (b) mostra a lente arenosa, esta é um ponto de 92 fragilidade do pacote de materiais. 
Unidade 2- caracteriza-se por ser constituída por um pacote de material Rs1 com espessura variando $0,5 \mathrm{~m}$ a $2 \mathrm{~m}$, que recobre o material Rs2 $( \pm 1 \mathrm{~m})$, abaixo deste ocorre 0 $\mathrm{Ra} 3$ e na base uma fina lente de argila. $O$ material Rs1 pode estar parcialmente recoberto por material retrabalhado enriquecido com matéria orgânica. Na figura 5.10, observar-se a distribuição espacial dos materiais que compõem a unidade 2 e suas respectivas espessuras em campo. Segundo moradores locais o material Rs1 foi explorado por muito tempo pelas pessoas que residiam próximo a esta feição, para construção de casas. A presença de lentes de argila são características de ocorrerem intercalando os arenitos da Formação Pirambóia.

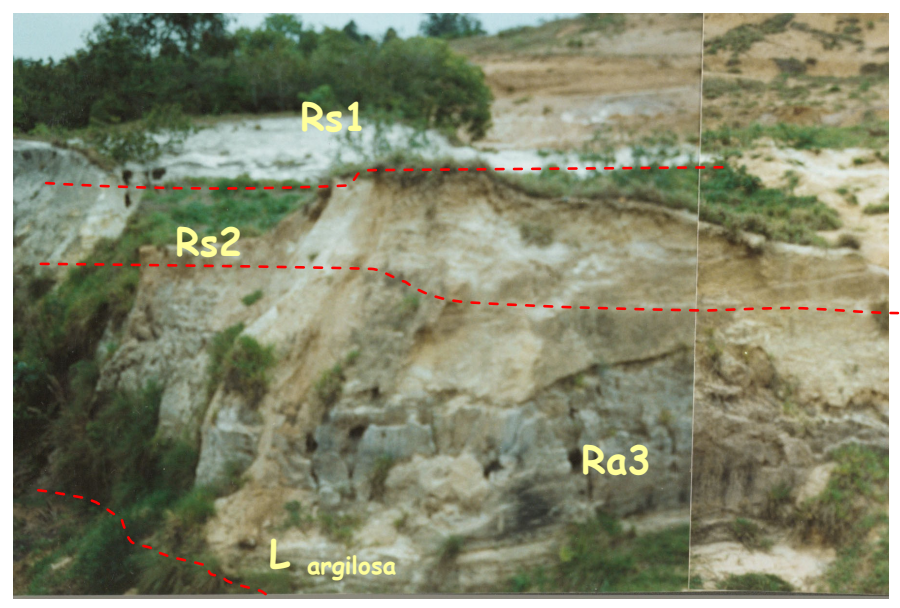

Figura 5.10: Materiais inconsolidados representativos das unidade2, instalados no final do canal da feição erosiva do Dimas.

Unidade 3- caracteriza-se por ser um vale muito fechado e com a presença de densa vegetação. No topo desta unidade ocorre material R+9 enriquecido com matéria orgânica de $\pm 1 m$, sotoposto encontra-se o material Rs1 de espessura $\pm 0,5 m$, e abaixo deste observa-se o material Rs2 de espessura inferior a 0,5 $\mathrm{m}$. Seguido há uma lente argilosa de $0,20 \mathrm{~m}$. A base desta unidade é constituída de arenito amarelado pouco alterado com estratificação plano paralela e bastante endurecido, isto se deve se ao fato da possível flutuação do nível de água (Figura 5.11). 


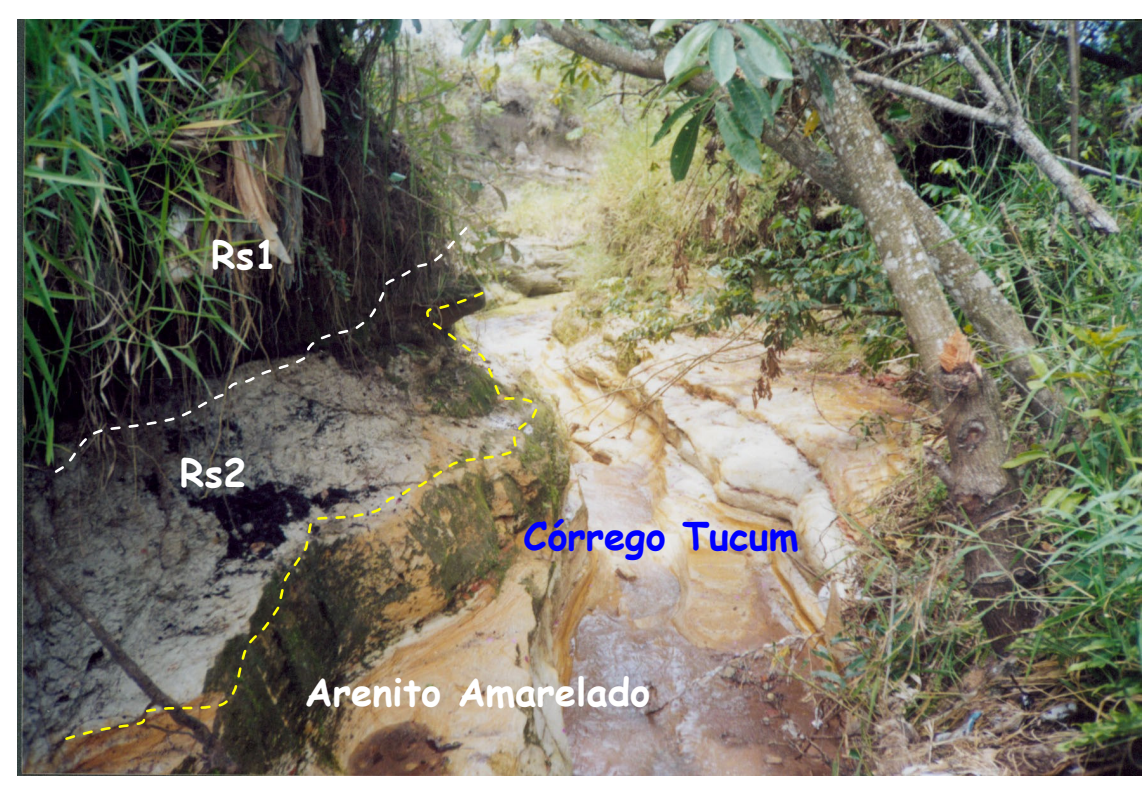

Figura 5.11: Tipos de Materiais inconsolidados representativos da unidade 3 (e arenito amarelado no talvegue do canal do Tucum.

Unidade 4- apresenta o talude constituído seqüencialmente a partir do topo com os seguintes materiais $R+3, R s 3$ e Ral, e na encosta esquerda o material $R+5$, associado localmente com uma lente de material conglomerático de matriz arenosa de coloração rosada com seixos de argilito, com espessura de 0,5 à $1 \mathrm{~m}$. Na encosta direita ocorre alternância lateral entre os materiais retrabalhado $R+5$ e os residuais Rs2 e Rs3, devido o trabalho de tratores na área para construção de cordões. Na Figura 5.12(a), pode-se observar a distribuição espacial e de espessuras no talude do Raia, nesta encosta ocorre lançamento de lixo pela população que habita o topo. O horizonte de material Rs3 apresenta-se intensamente sulcados pelos processos erosivos e sem a instalação de vegetação. Vale ressaltar que Ral apresenta ainda acamamento da rocha sã, mas com alto nível de alteração.

A Figura 5.12(b) observa-se a lente de material conglomerático associada ao material $R+5$. A lente mostra-se como um material critico da área, pois apresenta-se extremamente instável, sulcado e em deslizamento para o fundo da piscina da favela Raia. No fundo desta encontra-se o material Ra2, onde está assentada a tubulação de águas pluviais. Na Figura $5.12(c)$ observa-se a distribuição espacial dos materiais na encosta direita. 


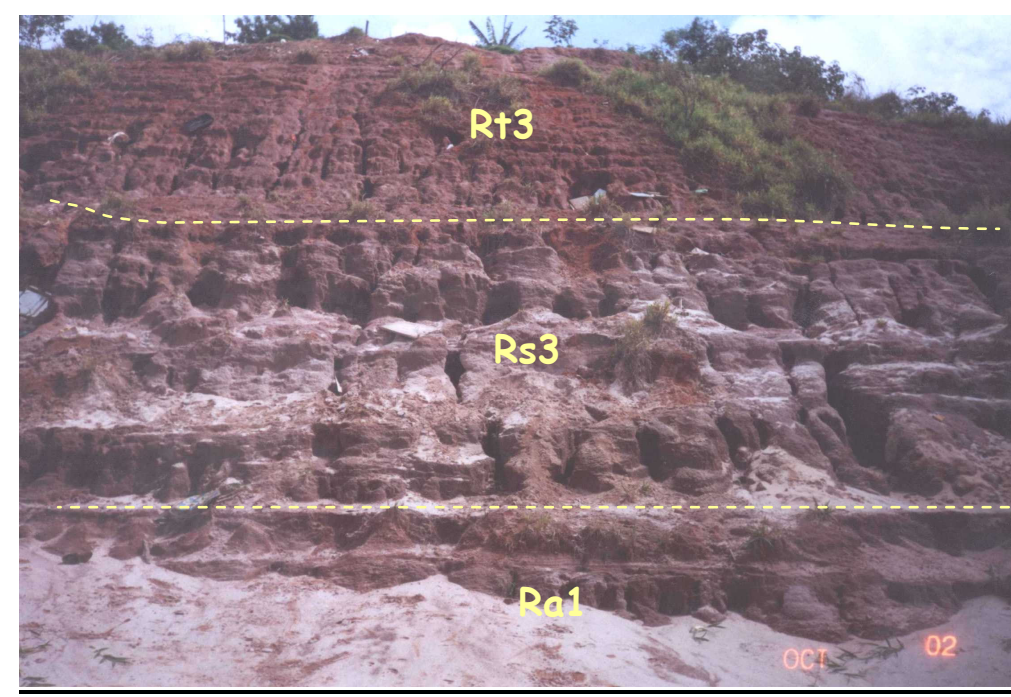

(a)

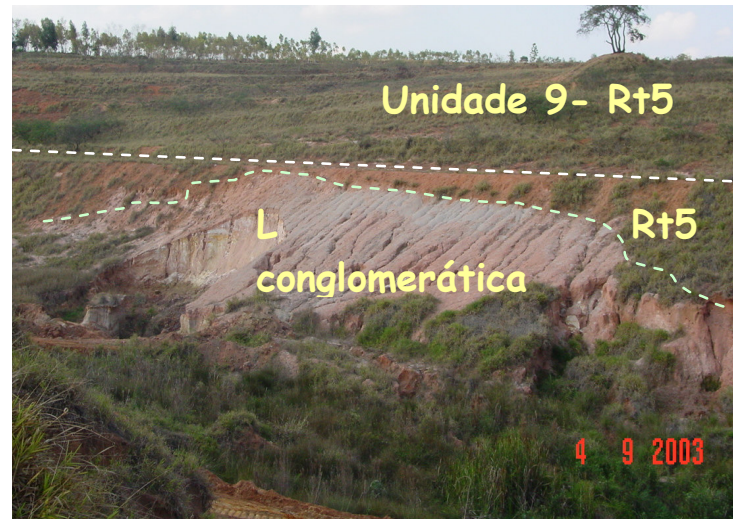

(b)

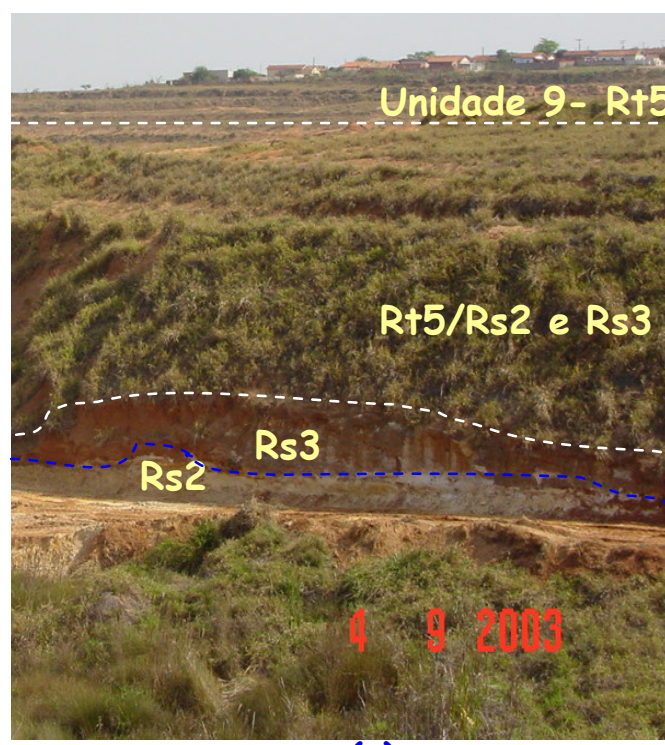

(c)

Figura 5.12: Materiais inconsolidados representativos da unidade 4 , localizado na favela Raia: a)talude ( $R+3, R s 3$ e Ra1), b)encosta esquerda ( $R+5$ e $L$ material conglomerático) e c) Encosta direita (Rt5,Rs2 e Rs3).

Unidade 5- caracterizada pela presença do material Rs1 com $3 \mathrm{~m}$ de espessura em toda a sua extensão, tendo uma camada superficial de $0,2 \mathrm{~m}$ enriquecida de matéria orgânica. Na figura 5.13, observar-se a distribuição espacial da unidade 5, associada com as outras que a cercam. Esta unidade se apresenta recoberta por pastagem e está localizada na encosta da Fazenda. Esta unidade sofreu terraceamente e mostra-se estável com relação aos processos erosivos.

Unidade 6- constituída por material R+9 enriquecido de matéria orgânica, bastante vegetada. Como observa-se na Figura 5.13. 
Unidade 7- caracteriza-se pela presença de uma camada de aproximadamente $1 \mathrm{~m}$ do material R+6, com certa laterização (mosqueado), recobrindo rocha alterada de coloração amarelada.

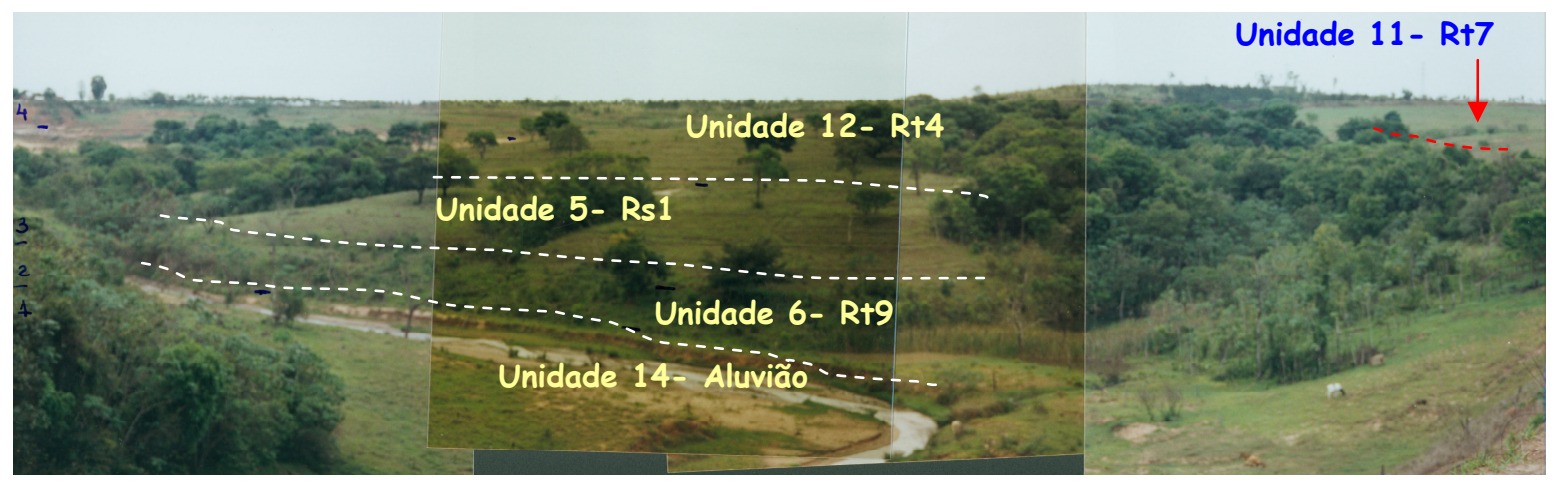

Figura 5.13: Materiais inconsolidados representativos da unidade 5, 6, 11, 12 e 14 localizado entre o leito do canal do Tucum e a Fazenda.

Unidade 8- constituída pelo material R+6, com espessura que varia de 3 a $5 \mathrm{~m}$. Apresenta-se bastante vegetada nos cordões superiores, é o processo erosivo relativamente estável.

Unidade 9- ocupa o maior área, caracterizada pelo material $R+5$, com espessuras variando de 2 a $10 \mathrm{~m}$. Este material ocupa as encostas do Raia e pode ser observado na figura $5.12(b)$ e (c).

Unidade 10- ocorre o material $R+1$, de coloração avermelhada, que se caracteriza por apresentar a maior percentagem da fração argila (15,5 a 15,9\%), com espessura em torno de $6 \mathrm{~m}$, tendo uma linha de seixos de 0,3 $\mathrm{m}$ de espessura separando-o do $\mathrm{R}+7$ como observa-se neste perfil ilustrado pela Figura 5.14(a), localizado na estrada de terra São Pedro- Charqueada. O material R+7 encontra-se instalado na transição ente os materias retrabalhado e os residuais como pode-se observar na Figura 5.14 (b) no canal do Dimas, este mostra-se como um material importante no contexto da evolução dos processos erosivos na área, por apresentar-se naturalmente mais compacto que os outros materiais. 

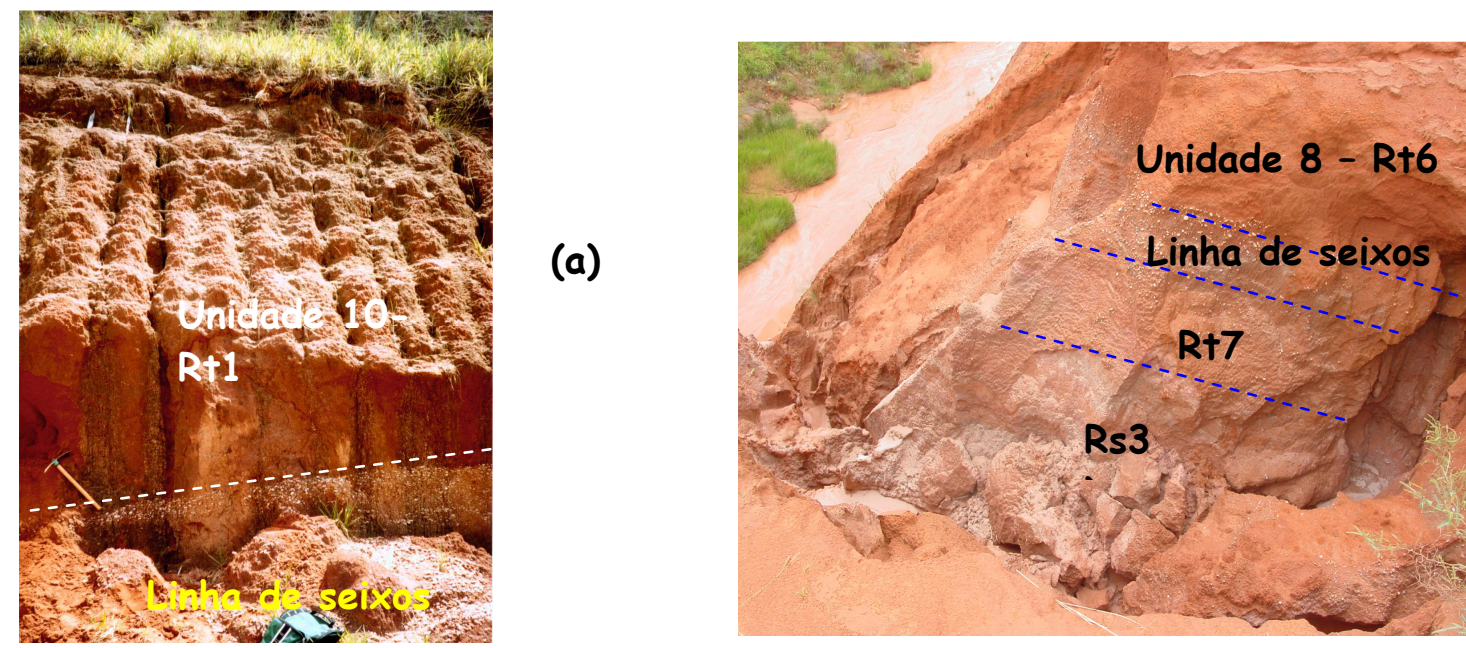

(b)

Figura 5.14: (a) Material inconsolidado representativo da unidade 10, localizado na margem da estrada de terra São Pedro-Charqueada e (b) exemplo de ocorrência do material $R+7$, que se localiza abaixo da linha de seixos, na transição entre os materiais retrabalhados e os residuais.

Unidade 11- caracterizada pela presença do material $R+2$ de coloração avermelhada, com $5 \mathrm{~m}$ de espessura e tendo uma camada de 0,5m enriquecida de matéria orgânica, recobrindo os materiais da unidade 12.

Unidade 12-apresenta o material R+4 de coloração avermelha-amarronzada, com espessura de $\pm 5 \mathrm{~m}$.

Unidade 13- caracteriza-se pela presença do material $R+3$, de coloração avermelhada e espessura variando de 2 a 12 m. Representa a maior extensão em área dentre todas as unidades e apresenta poucas porções ainda não ocupadas pelas expansão urbana. Como observa-se na figura 5.15.

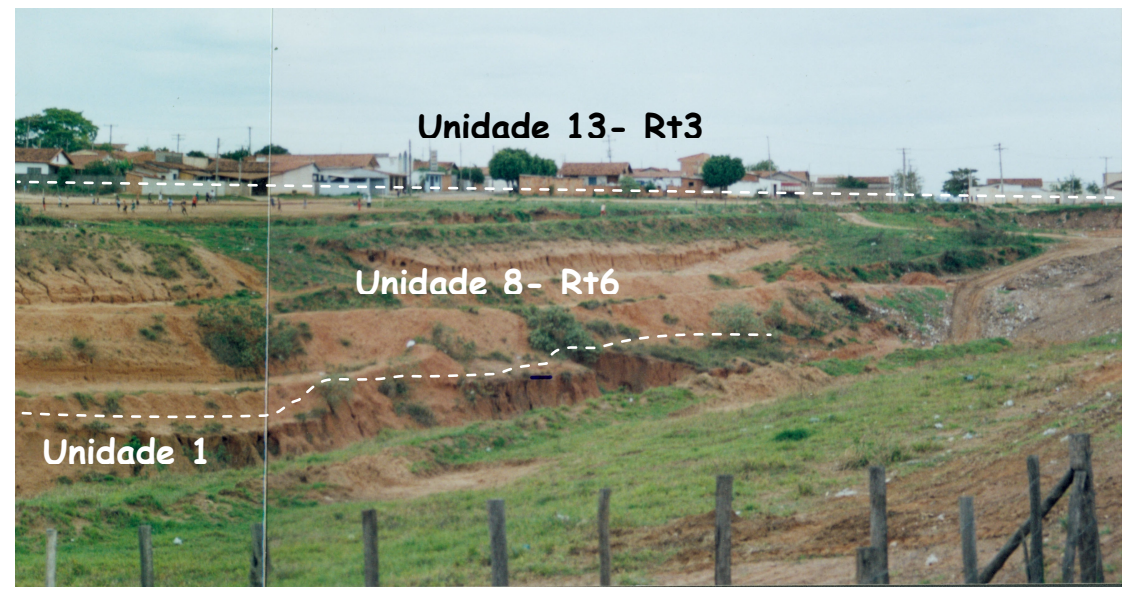

Figura 5.15- Observar o uso e ocupação, que deixa poucas porções do material R+3 ainda exposto.

Unidade 14- ocorre o material R+8 do tipo aluvionar, de coloração branca e com espessura em torno de $1 \mathrm{~m}$ ao longo do córrego do Tucum (Figura 5.13). 


\subsection{5- MAPA DE LANDFORMS (ANEXO V)}

O mapa de landforms foi elaborado a partir das fotos aéreas de 1962 (escala 1:25.000) por ser o registro fotográfico mais antigo, refletir os landforms básicos, não fazer parte da área urbana e ainda não tinham sido executadas as obras de contenções.

A definição e delimitação dos landforms seguiram as orientações de LOLLO (1996). O zoneamento do terreno em termos de landforms pode ser feito em três níveis hierárquicos, denominados de sistemas de terreno, unidade de terreno e elementos de terreno.

Neste trabalho devido a extensão, da área, escala e objetivo do trabalho optou-se por trabalhar com unidades e elementos de terreno (Figura 5.16).

Unidade de Terreno: é a forma individual do terreno que se diferencia por apresentar determinado subconjunto de processos, distinta dos demais. Assim, a delimitação é feita baseando-se nas características morfológicas como forma topográfica, a inclinação da vertente, amplitude do relevo e característica de organização da drenagem em termos de frequiência e estruturação dos canais;

Elemento de Terreno: corresponde a menor subdivisão de um terreno, baseando-se na inclinação ou formas das vertentes, posição ou forma topográfica do elemento. Esta deve refletir condições diferenciadas de espessura de materiais inconsolidados ou variações laterais no perfil destes materiais. 


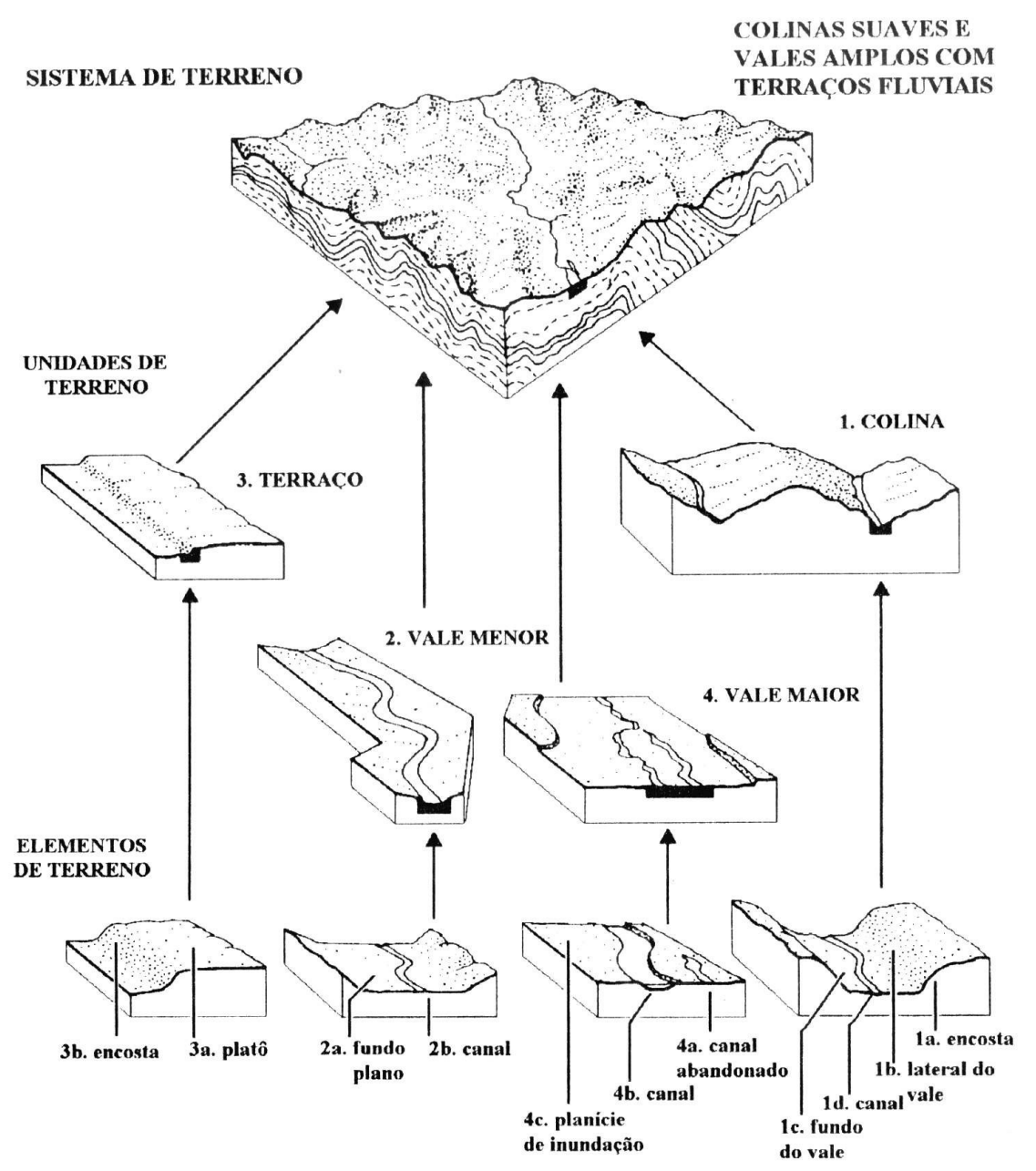

FIGURA 5.16- Aplicação da técnica de avaliação do terreno, modificada de Cooke \& Doornkam (1990), apud Lollo (1996).

Assim, a partir da fotointerpretação, transfere-se as informações para o mapa base, utilizando o equipamento Aero-Sketchmaster. Posteriormente, as unidades $e$ elementos de terreno foram digitalizados com o auxílio do programa AUTOCAD MAP ${ }^{\circledast}$.

Para a cabeceira da bacia do córrego Tucum foram individualizadas 6 unidades de terreno (Figura 5.17) e 21 elementos, os quais se encontram descritos a seguir:

UNIDADE A: é constituída por encostas com diferentes características (slope shape). De acordo com as formas a unidade foi subdividida em 5 elementos de terreno sendo o (A1) encosta côncava, o (A2) encosta convexa, (A3) encostas dissecadas-retilíneas e (A4) encosta côncava e encosta retilínea (A5). Na figura 5.17, observa-se a unidade A1localizada no topo da florestal e composta de material R+1, A4 e A5. Além de elementos de outras unidades como E1- localizada na fazenda, sofreu terraceamento e é composta de material R+2 e R+4 e F ocupada pela vegetação. 


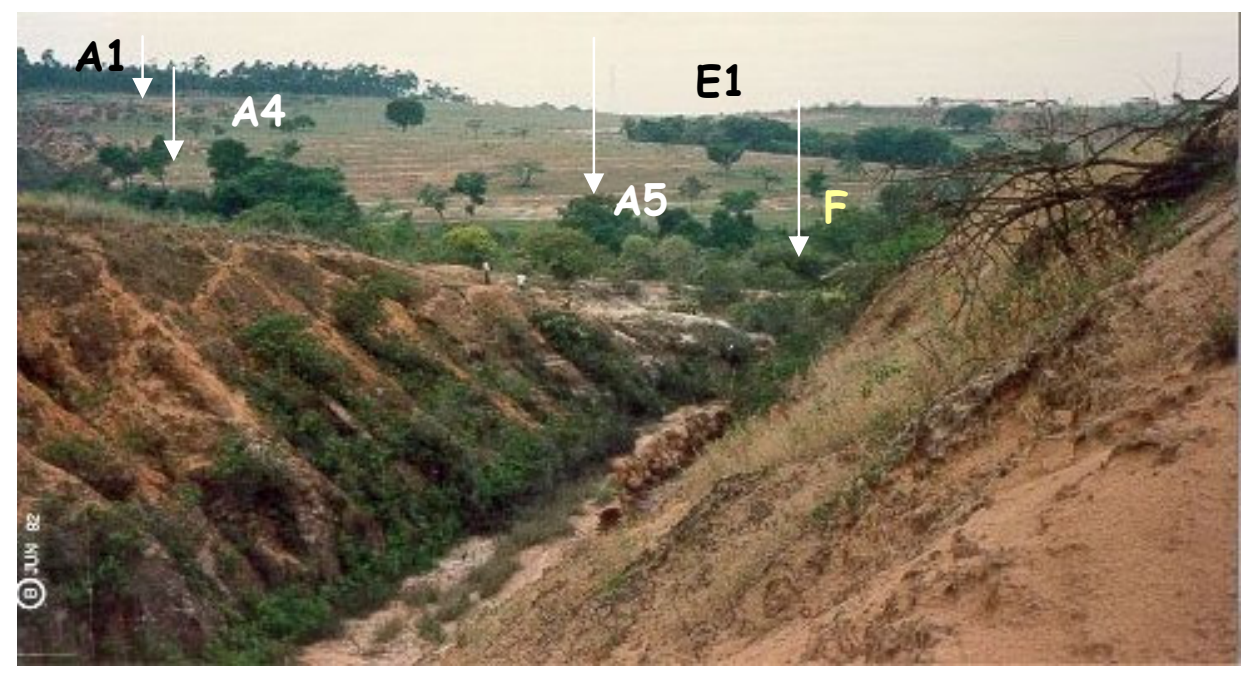

Figura 5.17: Observar nesta foto de 1992, a situação de alguns unidade e elementos de landforms ( $F, A 1, A 4, A 5$ e E1).

UNIDADE B: é composta por encostas com diferentes formas, que foram subdivididas em 4 elementos de terreno, baseada na forma e associação que se apresenta em: (B1) encosta retilínea, (B2) encosta côncova entre retilínea e convexa, (B3) encosta convexa e (B4) encosta côncava em seguida de convexa. Como se observa no modelo digital do terreno (MDT) sobreposto a fotografia aérea de 1962 (Figura, 5.18), os elementos de terreno da unidade $B$ encontram-se localizados na margem esquerda do córrego do Tucum. Estes sofreram muitas alterações ao longo do tempo, pois foram cortados pela construção da SP191, sofreram com sulcamento pelo processo erosivo e pela construção de cordões para conter o processo erosivo. 


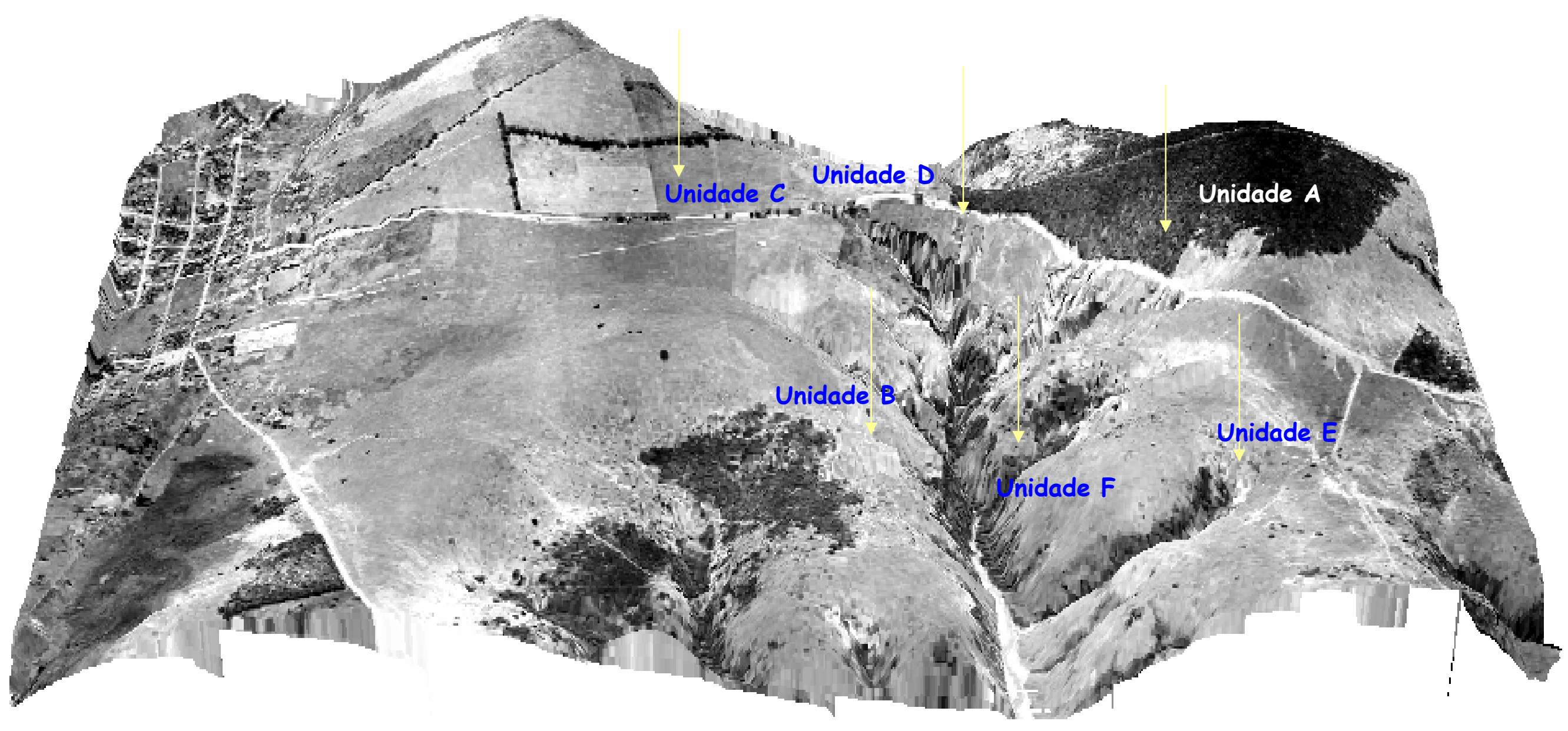

Figura 5.18- Modelo digital de terreno sobreposto à fotografia aérea de 1962, indicando o posicionamento espacial dos landforms, gerado a partir do software Envi@ 3.6 as setas mostram as unidades 
UNIDADE C: formada por encostas que foram subdivididas, segundo sua forma $e$ associação em 5 elementos do terreno sendo (C1) encosta convexa montante, (C2) encosta côncava bastante extensa, (C3) encosta convexa entre côncava e côncava/retilinea, (C4) encosta côncava e (C5) encosta retilíneas. A Figura 5.19, mostra a disposição de alguns landforms da unidade $C$, em 2003. O elemento $C 3$ encontra-se completamente ocupado por área urbana consolidada e composto exclusivamente por material $R+3$. Já o elemento C4 encontra-se remodelado pelos cordões e composto pelo material $R+6$. O canal do Dimas que representa o elemento $C 5$ constitui-se da unidade 1 de materiais inconsolidados e encontrase afetado pelo processo erosivo ate os dias atuais.

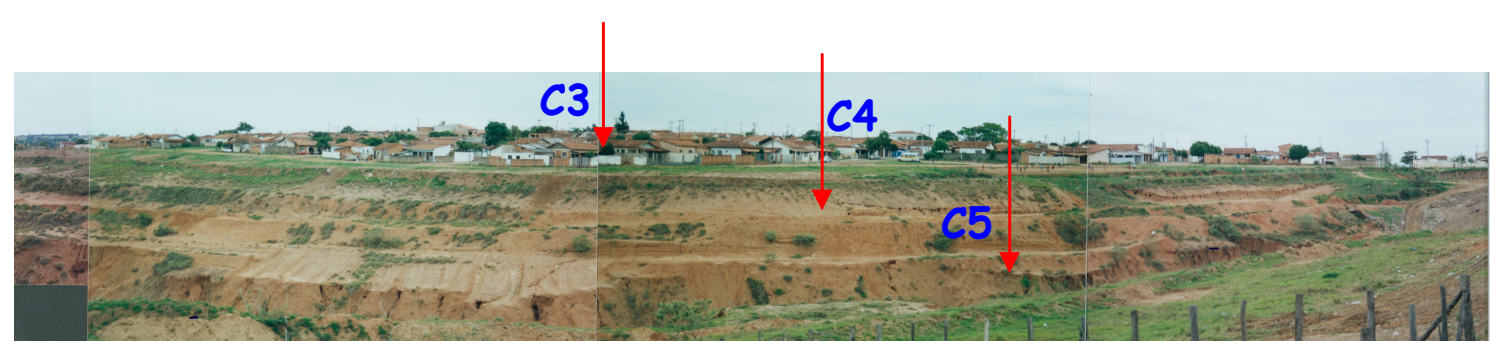

Figura 5.19: Encosta Direita do Canal do Dimas, nesta pode-se observar os landfoms C3,C4 e C5 em 2003.

UNIDADE D: é composta por encostas com diferentes formas. De acordo com esta foi subdividida em 3 elementos do terreno sendo (D1) encosta convexa, (D2) dissecadaretilíneas e (D3) encosta côncava. A Figura 5.20 mostra que os elementos da unidade $D$ foram totalmente alterados pelo retaludamento, aterramento, obras de drenagem de águas pluviais e cordões de nível. O elemento D1 compõe a encosta da favela Raia, esta é constituída por materiais inconsolidados do tipo Retrabalhado ( $R+3)$ e Residual (Rs3), e Rocha alterada (Ra1). Já o elemento D3 é composto basicamente de Rt3 e Residuias que foram expostos pelo trabalho das máquinas e o elemento D2 encontra-se no nível de base do antigo canal do Raia que foi canalizado.

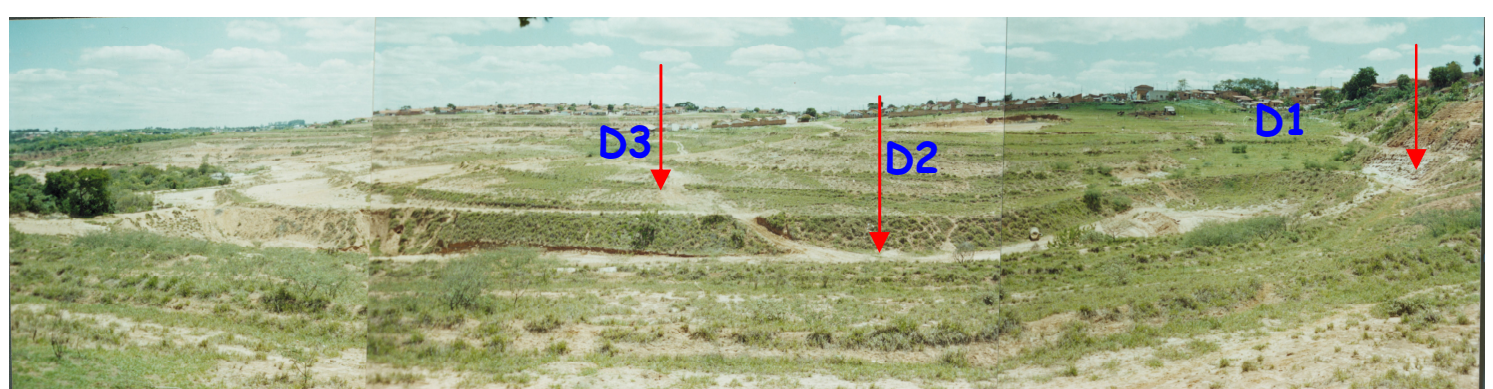

Figura 5.20: Observar os seguintes landforms da unidade D (D1, D2 e D3 ) na área da favela Raia, em 2003. Estes se encontram completamente alterados. 
UNIDADE E: caracteriza-se por encostas com diferentes formatos, que assim puderam ser subdivididas em 3 elementos do terreno sendo (E1) encosta côncava, (E2) encostas convexa e (E3) apresenta-se como área de topo. Na Figura 5.21, pode-se observar que o Landforms E1 e E2. O elemento E2 foi dividido pela estrada e o E3 ficou totalmente isolado fora da área de estudo na margem esquerda, no sentido Charqueada-São Pedro. No modelo digital de terreno sobreposto à fotografia aérea de 1978 , pode-se observar as alterações da paisagem provocadas pela estrada (Figura 5.22). Pode-se observar também elementos de outras unidades como A5 e F.

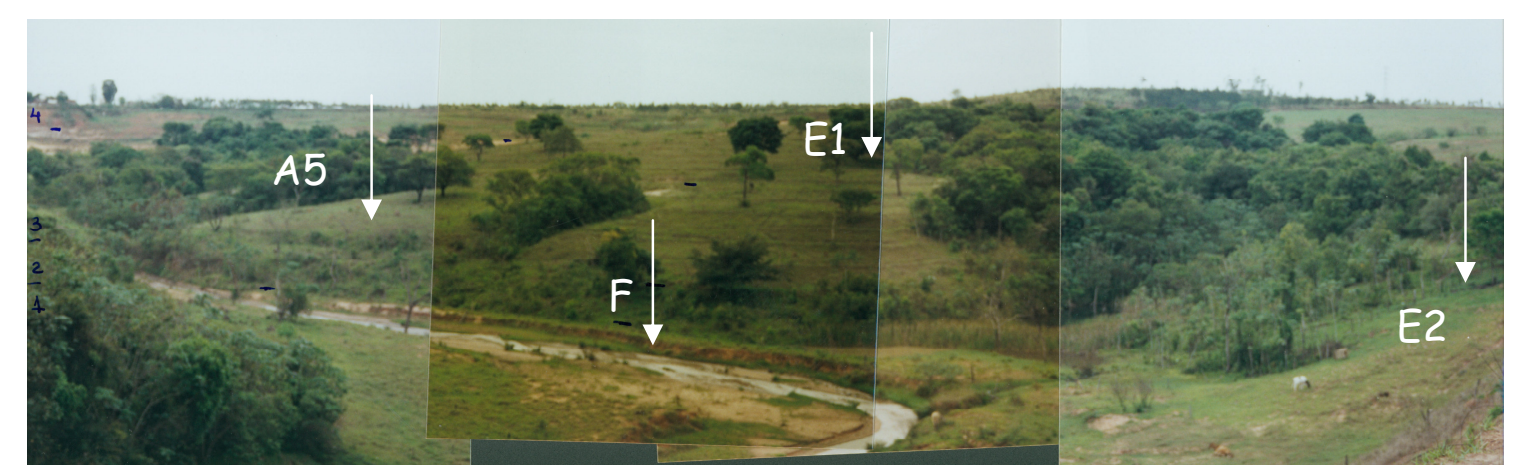

Figura 5.21: Nesta foto podemos observar os landforms A5, E1, E2 e F em 2003.

UNIDADE F: vale aberto com fundo chato, caracterizado pela presença de materiais aluvionares de espessura pequena e pela presença de vegetação no seu entorno. Esta se encontra totalmente assoreada pelos processos erosivos como pode-se observar na Figura 5.20 .

As unidades de Landforms apresentam-se altamente alteradas pelas obras de controle do processo erosivo. No modelo digital de terreno sobreposto à fotografia aérea de 2000, pode-se observar as alterações da paisagem provocadas pelas obras de controle de processos erosivos na bacia (Figura 5.23). Além de visualizar que houve uma suavização das encostas e hoje apresentam um aspecto visual mais controlado. Assim como os landforms sofreram modificações com os cortes e aterros, para fazer os cordões de nível. 


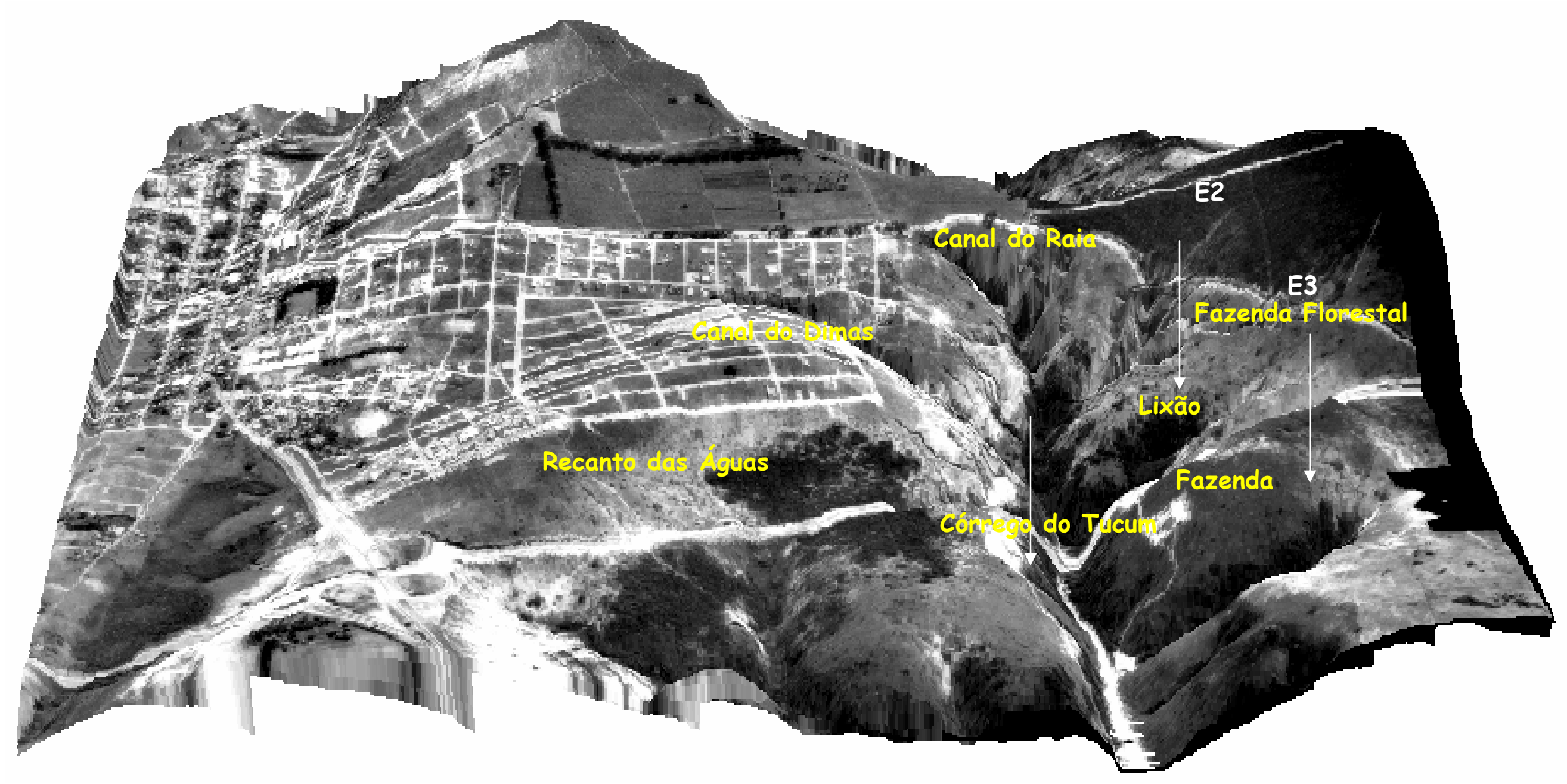

Figura 5.22- Modelo digital de terreno sobreposto à fotografia aérea de 1978, indicando o posicionamento espacial dos landforms, gerado a partir do software Envi@ 3.6 as setas mostram a unidade E e os elementos E2 e E3. 


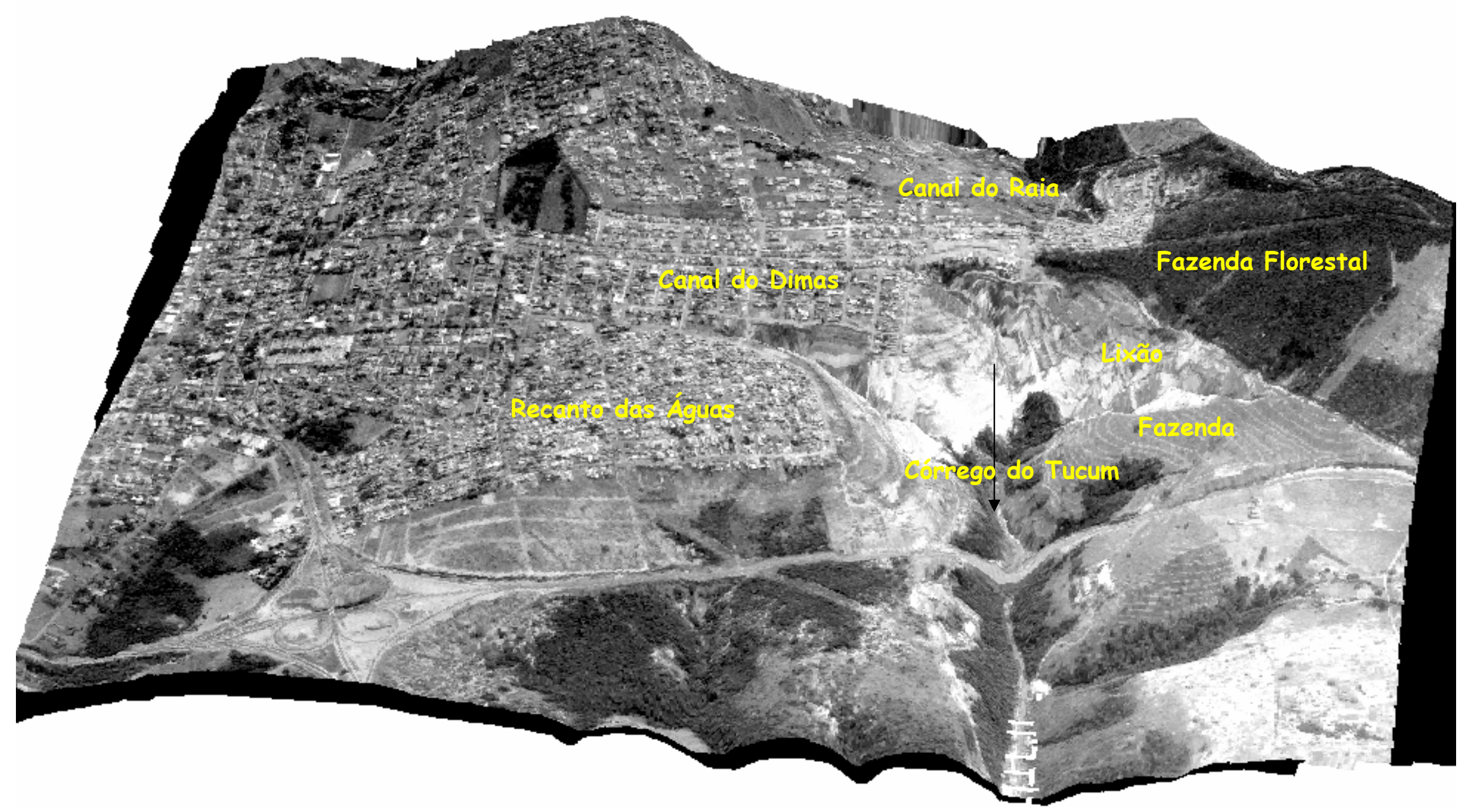

Figura 5.23- Modelo digital de terreno sobreposto à fotografia aérea de 2000, indicando o posicionamento espacial dos landforms, gerado a partir do software Envi@ 3.6 as setas mostram as unidades de elementos de terreno alterados pelas obras de controle executadas na cabeceira do córrego do Tucum 


\subsection{6- MAPA DE MICROBACIAS (ANEXO VI)}

O mapa de microbacias foi elaborado a partir das fotos aéreas do ano 2000 (escala 1:30.000) por serem o registro fotográfico mais recente da área. Assim, a partir da fotointerpretação, transferiu-se as microbacias delimitadas para o mapa base, utilizando o equipamento de Aero-Sketchmaster. Estas, depois de digitalizadas no mapa bases foram impressas associadas com a área urbana, drenagem e obras na área.

O sistema de águas pluviais em áreas urbanas é definido pelas bocas de lobo que coletam as águas que escoam pelas sarjetas das ruas, que seguem pelos tubos de ligação que transferem essas águas para os poços de visita e pelas galerias que levam as águas pluviais até canal principal, podendo ter no final da galeria associada uma escada hidráulica, que diminui a velocidade da água que vem sendo conduzida pelo sistema. Em áreas não urbanas o sistema de águas superficiais é constituído pelas encostas e canais de drenagem.

Como a bacia é constituída por áreas urbanizadas e não, procurou se os métodos adequados para o calculo das vazões de pico, no sentido de avaliar o volume de água gerada e executar o calculo dos diâmetros de galerias superficiais para dar vazão ao volume total. Neste sentido 3 métodos se destacam: Racional, da SCS e o de Segmentação. Este último foi descartado por ser aplicado em áreas totalmente urbanizadas ou em encostas bem caracterizadas. Já o método Racional é utilizado para bacias pequenas ( $\left.<5 \mathrm{Km}^{2}\right)$, mas não considera muitos atributos da bacia.

Por essa razão foi utilizado o método do "U.S. Soil Conservation Service- SCS", este foi formulado depois de diversos experimentos em bacias de pequeno porte, que é o caso deste estudo, além de estabelecer relações entre a precipitação, o deflúvio superficial, grau de vegetação e tipo de uso e ocupação, mostrando-se mais completo que os cálculos pelo método Racional.

Assim, o primeiro passo é a divisão da bacia em microbacias, e indicação das respectivas seções de contribuição (Anexo VI).

Para a cabeceira da bacia do córrego Tucuns foram individualizadas 19 microbacias, sendo que 6 no canal do Dimas, 6 no canal do Raia, 5 na confluência da fazenda, lixão $e$ florestal e duas ( 7 e 8) próximos a SP-191, que concentra as águas que descem pelos canais do Dimas, Raia e Florestal até este ponto de estrangulamento. Os dados de cada uma dessas bacias encontram-se na Tabela 5.7.

Na figura 5.24, observa-se exemplo de uma rede de drenagem urbana com os poços 
de visita, bocas de lobo e galerias formando uma rede de 16 trechos de galerias.

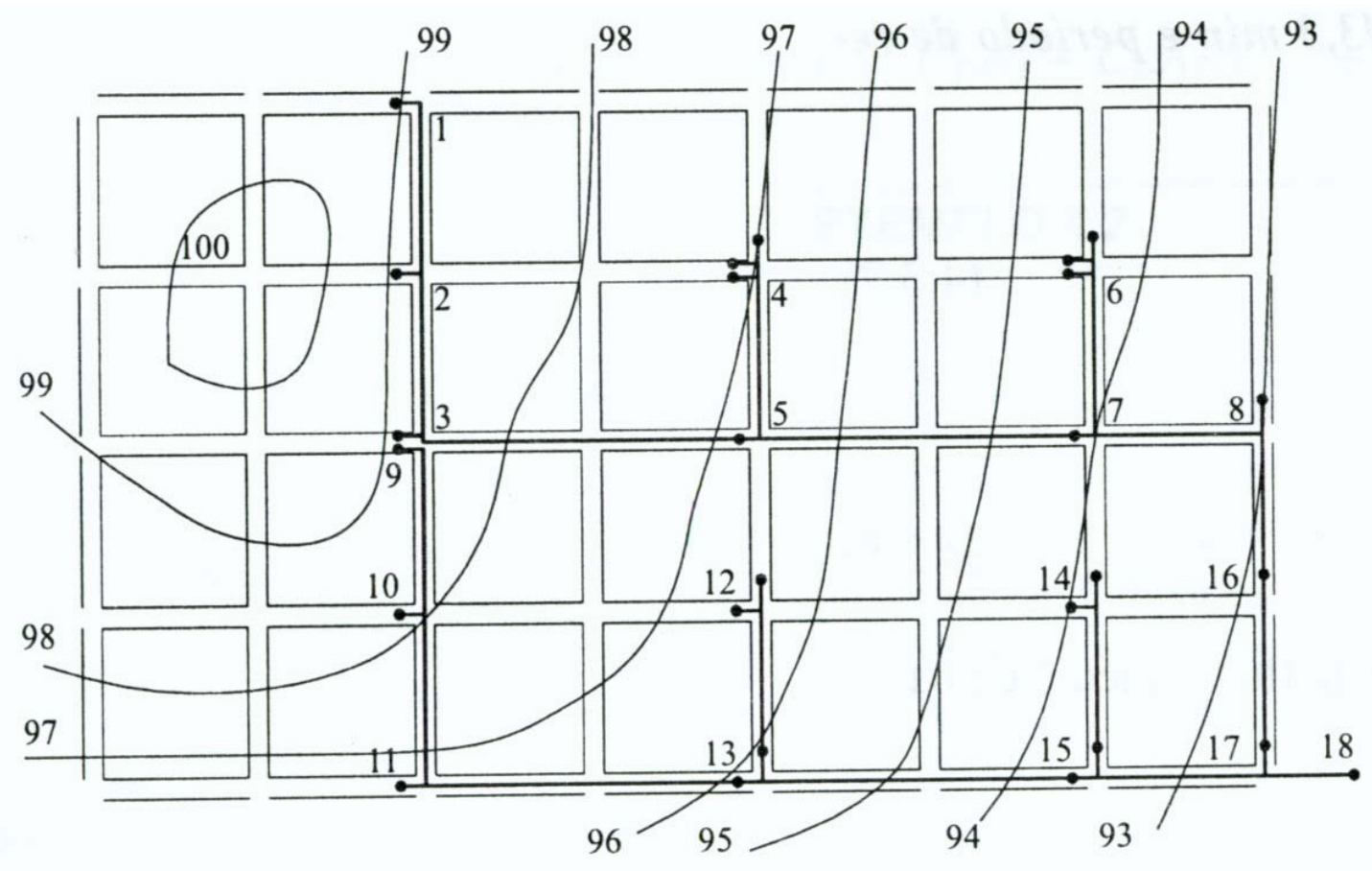

Figura 5.24- Exemplo de área urbana e sistema de galerias de águas pluviais (Righetto, 1998).

Observar no mapa do anexo VI que as vazões é relativo a toda a área de contribuição a montante de cada seção indicada no mapa, assim como os respectivos tempos de concentração. Para calcular a Qp para cada seção utilizou-se o método U.S. Soil Conservation Service, usando a Equação da 2.15.

$$
Q_{p}=\frac{2 \cdot h_{q} \cdot A}{t_{b}}
$$

onde $Q p=$ Vazão de pico;

hq = altura da lamina escoada, em m;

$A=$ área de contribuição em $\mathrm{m}^{2}$;

tb= tempo de base; em s;

Para Cálculo da altura da lâmina escoada $\left(h_{q}\right)$ utilizou-se a equação 2.16 de Hawkins et al, (1985). Entrado com os seguintes dados $h_{p}=$ altura de precipitação, em $\mathrm{mm} ; h_{q}=$ altura da lâmina escoada, em mm e $S$ = índice de armazenamento de água na bacia, em ( $\mathrm{mm}$ )

Para cálculo de S utilizou-se a eq. 2.17, que necessita que se estabeleça CN que é a Curva de deflúvio (definido pela SCS). Na tabela 5.5 pode-se observar os valores de CN que 
foram considerados nesta pesquisa, que levam em consideração o tipo de solo, uso $e$ ocupação e vegetação.

Tabela 5.5: Tabela da SCS com valores de CN para alguns tipos de solo, associados a tipos de uso e ocupação. Os tipos de solo seguem a seguinte classificação: Grupo A - solo arenosos profundos com baixo teor de argila; Grupo B- solo arenosos rasos com baixo teor de argila; Grupo C-solos barrentos com teor de argila entre 20 e 30\% e Grupo D-solos argilosos (Righetto, 1998).

\begin{tabular}{|c|c|c|c|c|}
\hline \multirow{2}{*}{ Ocupação do solo } & \multicolumn{4}{|c|}{ Tipos de solo da bacia } \\
\hline & $A$ & B & $C$ & $D$ \\
\hline \multirow{3}{*}{$\begin{array}{l}\text { Solo Cultivado: } \\
\text { - Sem técnica de conservação } \\
\text { - Com técnicas de conservação }\end{array}$} & & & & \\
\hline & 72 & 81 & 88 & 91 \\
\hline & 62 & 71 & 78 & 81 \\
\hline \multirow{3}{*}{$\begin{array}{l}\text { Pastagem: } \\
\begin{array}{l}\text { - } \quad \text { Condição precária } \\
\text { - Condição adequada }\end{array}\end{array}$} & & & & \\
\hline & 68 & 79 & 86 & 89 \\
\hline & 39 & 61 & 74 & 80 \\
\hline \multirow{3}{*}{$\begin{array}{l}\text { Área florestada: } \\
\text { - } \quad \text { Pouca cobertura } \\
\text { - } \quad \text { Grande cobertura }\end{array}$} & & & & \\
\hline & 45 & 66 & 77 & 83 \\
\hline & 25 & 55 & 70 & 77 \\
\hline \multirow{3}{*}{$\begin{array}{l}\text { Parques e jardins: } \\
\begin{array}{l}\text { - } 75 \% \text { de área gramada } \\
\text { - } 50 \text { a } 75 \% \text { de área gramada }\end{array}\end{array}$} & & & & \\
\hline & 39 & 61 & 74 & 80 \\
\hline & 49 & 69 & 79 & 84 \\
\hline Áreas comerciais (85\%de área impermeável) & 89 & 92 & 94 & 95 \\
\hline Áreas industriais (72\% de área impermeável) & 81 & 88 & 91 & 93 \\
\hline \multirow{4}{*}{$\begin{array}{l}\text { Áreas residenciais: } \\
\begin{array}{l}\text { - } \quad 65 \% \text { de área impermeável } \\
\text { - } 3 \% \text { de área impermeável } \\
\text { - } \quad 25 \% \text { de área impermeável }\end{array}\end{array}$} & & & & \\
\hline & 77 & 85 & 90 & 92 \\
\hline & 61 & 75 & 83 & 87 \\
\hline & 54 & 70 & 80 & 85 \\
\hline Áreas impermeáveis & 98 & 98 & 98 & 98 \\
\hline Pavimento com pedrisco & 76 & 85 & 89 & 91 \\
\hline Pavimento com drenagem & 98 & 98 & 98 & 98 \\
\hline
\end{tabular}

$O h_{q}$ obtido encontra-se em $\mathrm{mm}$, são necessárias então as devidas transformações para obtê-lo em metros. Que é a unidade de entrada na $Q_{p}$ da SCS.

Para determinar o tempo de base ( $t_{b}$ ) utilizou-se a equação 2.18. Que é função do $t_{p}$ em hs. Então é necessário determinar primeiro o $t_{b}$, que então foi calculado a parti da 
equação 2.19 .

Os dados de entrada desta equação são: $D=$ duração da chuva, em horas e tc $=$ Tempo de concentração, existem várias equações para determinar este parâmetro mas neste trabalho utilizou a Eq 2.4, modificada da Fórmula de Kirpich (1940).

$O t_{b}$ obtido encontra-se em hs, são necessárias então as devidas transformações para obtê-lo em segundos. Que é a unidade de entrada na $Q_{p}$ da SCS.

Na região de São Pedro não se tem dados do DAEE sobre eventos de chuva, sendo o município mais próximo com este tipo de informação Santa Maria da Serra. Uma análise destes dados mostrou que estes não refletem os eventos que ocorrem em São Pedro, principalmente próximo ao córrego do Tucum. Vale ressaltar ainda que mesmo os dados do DAEE de chuvas diárias, agora medidos no alto da serra, podem não refletir a intensidade diárias de chuva que ocorre nas regiões periféricas.

Assim, através do monitoramento realizado durante projeto intitulado de Elaboração de cartas de eventos perigosos e riscos associados aos processos erosivos -escala 1:10.000-região de São Pedro(SP): desenvolvimento metodológico, realizado em 2000, pelo prof Dr. Lázaro Zuquette (Relatório da FAPESP, processe $n^{\circ}$ 00/03027-7), foram identificados 12 eventos de chuva característicos, e aqueles que estão acima da intensidade considerada básica, ou seja, freqüentes ou típicos de ocorrer diariamente nos meses de chuva no município. Estes estão descritos a seguir:

1- Chuvas com intensidade de $0,2 \mathrm{~mm} / \mathrm{min}$, ou menores e 1 hora de duração;

2- Chuvas com intensidade de 0,3mm/min e 1 hora de duração;

3- Chuvas com intensidade da ordem de $0,5 \mathrm{~mm} / \mathrm{min}$ e duração variando de 45 minutos a 1 hora, mas com predomínio da ordem de 45 minutos;

4- Chuvas da ordem de $0,7 \mathrm{~mm} / \mathrm{min}$ e duração de 1 hora;

5- Chuvas com duração de 35 min e intensidade de $1,1 \mathrm{~mm} / \mathrm{min}$;

6- Chuvas com $1,3 \mathrm{~mm} / \mathrm{min}$, e duração de até 1 hora, porém com predomínio de 30minutos;

7- Chuvas de 20 minutos de duração com intensidade de $1 \mathrm{~mm} / \mathrm{min}$;

8- Chuvas de $8,4 \mathrm{~mm} / 5 \mathrm{~min}$ e duração de 5 a 10 minutos;

9- Chuvas de $14 \mathrm{~mm} / 10$ mim e duração de 10 minutos; 
10- Chuvas de $20 \mathrm{~mm} / 15$ minuos e duração de 15 minutos;

11- Chuvas com duração de 3 horas e intensidade de $0,2 \mathrm{~mm} / \mathrm{min}$;

12- Chuvas com duração de 12 horas e intensidade de $0,2 \mathrm{~mm} / \mathrm{min}$.

Para todos estes eventos foram executadas simulações para cálculo das vazões, variando nos cálculos a intensidade e duração de cada evento como mostrado nas tabela 5.6 e 5.7. A primeira mostra a planilha básica de calculo e como exemplo a simulação para o evento 5 e a segunda mostra todas as vazões simuladas para cada ponto. 
Tabela 5.6- Vazões de pico para cada seção específicas dentro das microbacias, para o evento 5 (calculado pelo método da SCS, citado em

\begin{tabular}{|c|c|c|c|c|c|c|c|c|c|c|c|c|c|}
\hline seção & $L(K m)$ & $L(m)$ & $H(m)$ & $S$ & $t c(h s)$ & Dur (hs) & $t p(h s)$ & $t b(h s)$ & $C N$ & $h p(m m)$ & $h q$ & $A(m 2)$ & $Q p\left(m^{3} / s\right)$ \\
\hline 1 & 0,750 & 750,0 & 50,0 & 0,067 & 0,150 & 0,580 & 0,290 & 1,335 & 77 & 38,5 & 25,23 & 567746,92 & 9,203 \\
\hline 2 & 0,805 & 805,0 & 55,0 & 0,068 & 0,157 & 0,580 & 0,291 & 1,335 & 77 & 38,5 & 25,23 & 599439,61 & 9,611 \\
\hline 3 & 0,880 & 880,0 & 60,0 & 0,068 & 0,168 & 0,580 & 0,291 & 1,335 & 77 & 38,5 & 25,23 & 639273,24 & 10,073 \\
\hline 4 & 1,060 & 1060,0 & 75,0 & 0,071 & 0,191 & 0,580 & 0,292 & 1,335 & 60 & 38,5 & 30,77 & 694747,45 & 13,414 \\
\hline 5 & 1,154 & 1154,0 & 80,0 & 0,069 & 0,206 & 0,580 & 0,292 & 1,335 & 58 & 38,5 & 31,22 & 777017,60 & 14,945 \\
\hline 6 & 1,344 & 1344,0 & 92,0 & 0,068 & 0,233 & 0,580 & 0,291 & 1,335 & 62 & 38,5 & 30,30 & 843605,81 & 15,058 \\
\hline 7 & 1,489 & 1489,0 & 102,0 & 0,069 & 0,252 & 0,580 & 0,291 & 1,335 & 62 & 38,5 & 30,30 & 1828133,26 & 31,787 \\
\hline 8 & 1,639 & 1639,0 & 114,0 & 0,070 & 0,269 & 0,580 & 0,292 & 1,335 & 58 & 38,5 & 31,22 & 1952206,00 & 34,380 \\
\hline & & & & & & & & & & & & \\
\hline $1 c$ & 0,250 & 250,0 & 30,0 & 0,120 & 0,051 & 0,580 & 0,322 & 1,335 & 65 & 38,5 & 29,52 & 90946,630 & 2,106 \\
\hline $2 c$ & 0,310 & 310,0 & 45,0 & 0,145 & 0,056 & 0,580 & 0,337 & 1,335 & 65 & 38,5 & 29,52 & 139061,070 & 3,191 \\
\hline $3 c$ & 0,640 & 640,0 & 55,0 & 0,086 & 0,120 & 0,580 & 0,302 & 1,335 & 65 & 38,5 & 29,52 & 228499,660 & 4,686 \\
\hline $4 c$ & 0,690 & 690,0 & 60,0 & 0,087 & 0,127 & 0,580 & 0,302 & 1,335 & 65 & 38,5 & 29,52 & 341473,220 & 6,927 \\
\hline $5 c$ & 0,750 & 750,0 & 63,0 & 0,084 & 0,137 & 0,580 & 0,300 & 1,335 & 56 & 38,5 & 31,63 & 349499,590 & 7,588 \\
\hline $6 c$ & 0,840 & 840,0 & 64,0 & 0,076 & 0,155 & 0,580 & 0,296 & 1,335 & 56 & 38,5 & 31,63 & 365183,440 & 7,702 \\
\hline & & & & & & & & & & & & \\
\hline $1 d$ & 0,450 & 450,0 & 70,0 & 0,156 & 0,073 & 0,580 & 0,343 & 1,335 & 55 & 38,5 & 31,83 & 150458,300 & 3,672 \\
\hline $2 d$ & 0,540 & 540,0 & 71,0 & 0,131 & 0,090 & 0,580 & 0,329 & 1,335 & 55 & 38,5 & 31,83 & 256508,260 & 6,078 \\
\hline $3 d$ & 0,630 & 630,0 & 73,0 & 0,116 & 0,106 & 0,580 & 0,320 & 1,335 & 55 & 38,5 & 31,83 & 402507,060 & 9,273 \\
\hline $4 d$ & 0,170 & 170,0 & 28,0 & 0,165 & 0,034 & 0,580 & 0,349 & 1,335 & 47 & 38,5 & 33,21 & 53631,210 & 1,484 \\
\hline $5 d$ & 0,620 & 620,0 & 65,0 & 0,105 & 0,109 & 0,580 & 0,313 & 1,335 & 45 & 38,5 & 33,50 & 172836,06 & 4,223 \\
\hline & & & & & & & & & & & & \\
\hline
\end{tabular}

$L=$ largura do canal principal (em $m$ ou $\mathrm{Km}$ );

$H=$ diferença de cotas entre o inicio e o fim do canal;

tb= tempo de base em horas,

$\mathrm{S}=$ declividade;

tc= tempo de concentração em horas;

Dur= duração do evento de chuva em horas; $\mathrm{hp}=$ altura de precipitação em $\mathrm{mm}$;

$\mathrm{CN}=$ adimensional, adotado:

hq= altura da lamina escoada; em $\mathrm{mm}$;

$A=$ área em $\mathrm{m}^{2}$;

$t p=$ tempo de pico em horas;

$Q p=V a z a ̃ o ~ d e ~ p i c o ; ~ e m ~ m^{3} / s$ (hq- em m e tb- em s) 
Tabela 5.7- Vazões de pico para cada seção específicos de microbacias para diversos eventos de chuvas típicos para a área.

\begin{tabular}{|c|c|c|c|c|c|c|c|c|c|c|c|c|c|}
\hline \multirow{3}{*}{ seção } & \multirow{3}{*}{$A(m 2)$} & \multicolumn{12}{|c|}{$Q p(m / s)$} \\
\hline & & \multicolumn{12}{|c|}{ Eventos Comuns- Típicos para Área } \\
\hline & & Evento1 & Evento2 & Evento3 & Evento4 & Evento5 & Evento6 & Evento7 & Evento8 & Evento9 & Evento10 & Evento11 & Evento12 \\
\hline 1 & 567746,92 & 2,521 & 3,493 & 5,240 & 10,838 & 9,203 & 10,366 & 8,757 & 7,660 & 9,933 & 10,386 & 2,110 & 1,041 \\
\hline 2 & 599439,61 & 2,643 & 3,662 & 5,484 & 11,305 & 9,611 & 10,813 & 9,098 & 7,958 & 10,238 & 10,758 & 2,222 & 1,098 \\
\hline 3 & 639273,24 & 2,787 & 3,862 & 5,765 & 11,824 & 10,073 & 11,309 & 9,456 & 8,271 & 10,510 & 11,130 & 2,359 & 1,170 \\
\hline 4 & 694747,45 & 3,248 & 4,681 & 7,135 & 15,917 & 13,414 & 15,034 & 11,280 & 9,675 & 11,797 & 13,162 & 3,190 & 2,068 \\
\hline 5 & 777017,60 & 3,604 & 5,209 & 7,928 & 17,715 & 14,945 & 16,715 & 12,358 & 10,584 & 12,720 & 14,347 & 3,608 & 2,407 \\
\hline 6 & 843605,81 & 3,764 & 5,409 & 8,146 & 17,733 & 15,058 & 16,769 & 12,445 & 10,690 & 12,606 & 14,326 & 3,747 & 2,393 \\
\hline 7 & 1828133,26 & 8,015 & 11,516 & 17,270 & 37,334 & 31,787 & 35,304 & 25,994 & 22,329 & 25,968 & 29,760 & 8,064 & 5,176 \\
\hline 8 & 1952206,00 & 8,533 & 12,334 & 18,505 & 40,388 & 34,380 & 38,107 & 27,427 & 23,488 & 26,917 & 31,254 & 8,857 & 6,010 \\
\hline $1 \mathrm{c}$ & 90946,630 & 0,483 & 0,691 & 1,091 & 2,564 & 2,106 & 2,429 & 2,049 & 1,765 & 2,657 & 2,575 & 0,420 & 0,245 \\
\hline $2 c$ & 139061,070 & 0,735 & 1,050 & 1,656 & 3,879 & 3,191 & 3,675 & 3,086 & 2,658 & 3,957 & 3,863 & 0,641 & 0,374 \\
\hline $3 c$ & 228499,660 & 1,126 & 1,610 & 2,487 & 5,614 & 4,686 & 5,318 & 4,248 & 3,659 & 4,859 & 5,110 & 1,027 & 0,610 \\
\hline $4 \mathrm{c}$ & 341473,220 & 1,672 & 2,389 & 3,684 & 8,287 & 6,927 & 7,851 & 6,244 & 5,378 & 7,078 & 7,486 & 1,531 & 0,911 \\
\hline $5 c$ & 349499,590 & 1,746 & 2,530 & 3,928 & 9,113 & 7,588 & 8,590 & 6,545 & 5,598 & 7,221 & 7,808 & 1,691 & 1,134 \\
\hline $6 c$ & 365183,440 & 1,790 & 2,595 & 4,008 & 9,219 & 7,702 & 8,689 & 6,549 & 5,601 & 7,069 & 7,749 & 1,755 & 1,183 \\
\hline $1 d$ & 150458,300 & 0,807 & 1,171 & 1,855 & 4,474 & 3,672 & 4,215 & 3,352 & 2,865 & 4,088 & 4,146 & 0,752 & 0,501 \\
\hline $2 d$ & 256508,260 & 1,351 & 1,960 & 3,089 & 7,377 & 6,078 & 6,950 & 5,454 & 4,661 & 6,450 & 6,674 & 1,273 & 0,852 \\
\hline $3 d$ & 402507,060 & 2,083 & 3,023 & 4,739 & 11,214 & 9,273 & 10,565 & 8,191 & 7,001 & 9,431 & 9,928 & 1,985 & 1,335 \\
\hline $4 d$ & 53631,210 & 0,306 & 0,448 & 0,724 & 1,835 & 1,484 & 1,723 & 1,387 & 1,180 & 1,838 & 1,769 & 0,286 & 0,205 \\
\hline $5 d$ & 172836,06 & 0,911 & 1,336 & 2,109 & 5,128 & 4,223 & 4,812 & 3,618 & 3,075 & 4,105 & 4,378 & 0,904 & 0,676 \\
\hline
\end{tabular}




\subsection{7- MAPA DE LOCALIZAÇÃO DE OBRAS DE CONTROLE DE EROSÃO}

Este mapa foi elaborado a partir da foto aérea de 1988, 1995 e 2000. O inventário das obras de controle das feições erosivas foi feito a partir de trabalhos de campo, foto interpretação e de projetos fornecidos pela prefeitura. Assim, a partir do trabalho de campo, transferiu-se para o mapa base a localização dos pontos de obras de controle, sobreposto a foto aérea de 2000. Neste mapa observa-se o cadastro atual das obras na área e seu monitoramento. Vale ressaltar que muitas destas obras entram em colapso constantemente com o período mais chuvoso.

A primeira Fase de Projeto teve inicio em 1992, depois da doação pelo município de São Pedro de lotes nos bairros Recanto das águas, São Dimas e Estrada de terra São Pedro Charqueada. Assim, foram iniciadas as primeiras obras de contenção do processo erosivo como:

- Aterramento das feições existentes (sulcos, ravinas e voçorocas);

- Terraplanagem (rebaixou os taludes e aplainou o terreno);

- Terraceamento em nível (murundus);

- Diques internos (construídos com material retrabalhado e espaçados em termos do perfil do canal);

- Diques marginais;

- Drenos de bambu (colocados com a finalidade de drenar águas subterrâneas, estes foram construídos a partir de feixes de bambu envoltos em lona de plástico)

- Retaludamento

Algumas destas obras constam do cadastro, mais muitas delas que foram executadas com verba somente da prefeitura, não possuem registro algum. Por tratar-se de obras emergenciais e de movimento de máquinas agrícola cedida pelo Estado para construção de pequenas obras de beneficiamento do município como por ex: os cordões. $A$ Figura 5.29, mostra a construção de terraceamento em nível (murundus)e aterramento das feições em 1992. 


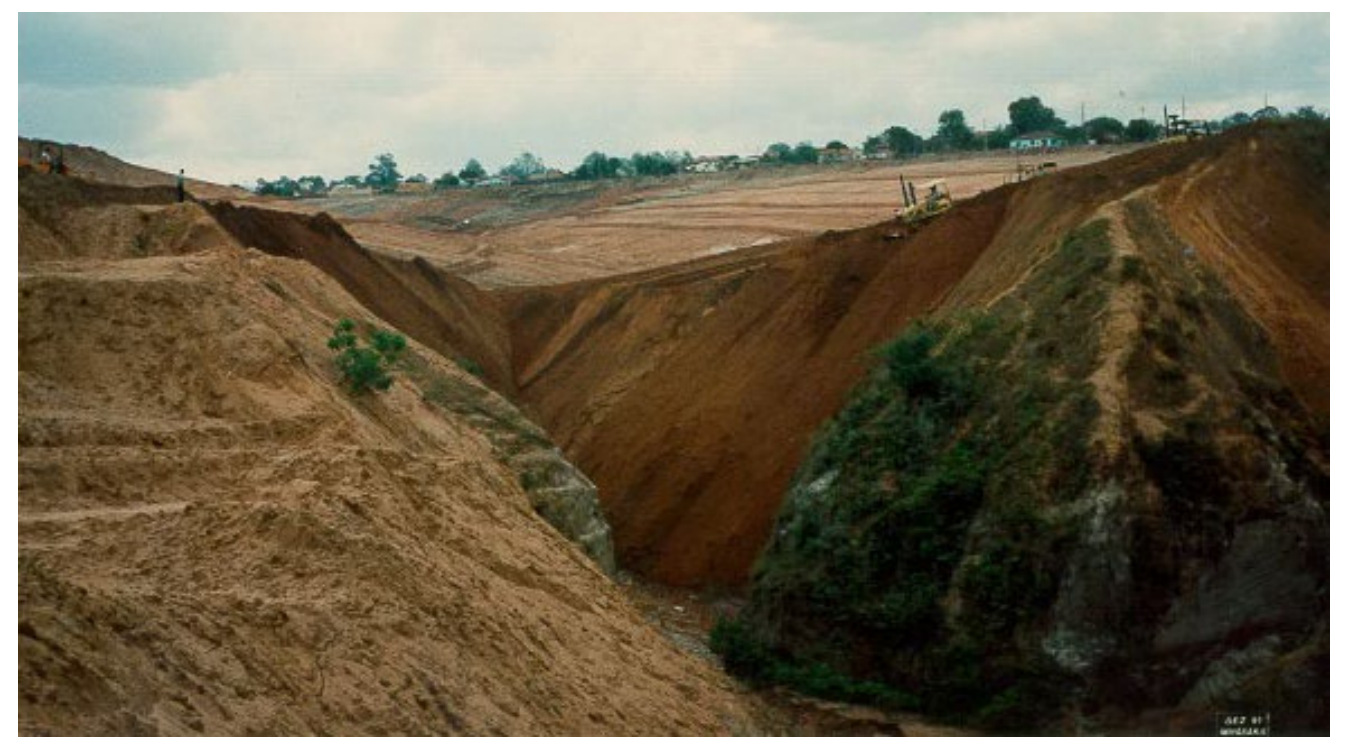

Figura 5.29: observa-se a construção do Terraceamento em nível (murundus) em 1992 (Pejon e Zuquette, 2001)

A segunda fase teve início com as recomendações feitas pelo IPT (1993), devido "a reativação do processo após as obras executadas em 92 e 93. Assim, foram executadas novas obras em 1994 como, pode ser observado na fotografia aérea de 1995:

- Abertura de valas com profundidade média de $2,30 \mathrm{~m}$ e preparação do seu fundo com berço de pedra. Para assentamento da tubulação

- Aterramento para preencher as feições presentes, foi utilizado os materiais $R+1, R+2, R+3, R+4, R+5$ e $R+6$. Já a feição erosiva da florestal passou a ser aterrada desde 1993 com resíduos sólidos provenientes da coleta seletiva (Figura 5.30).

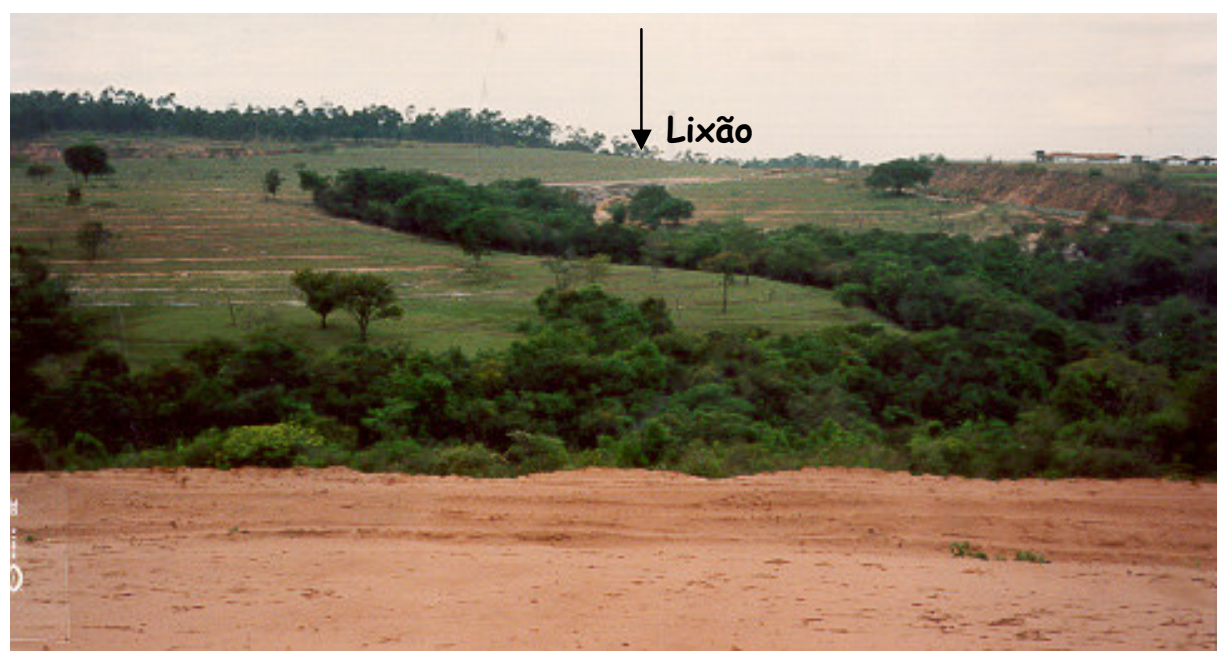

Figura 5.30: observa-se a utilização de lixo como aterro na área da fazenda em 1992. 
A área foi novamente terraplenada, retaludada e cordões de nível foram construídos. Estes apresentavam-se bem distribuídos em termos de espaçamento, altura em torno de $\pm 1 \mathrm{~m}$, com material retrabalhado. Não foram construídos em alguns lugares $e$ concentravam água em alguns pontos. O projeto não respeitou os divisores de água, a topografia e a forma da encosta. Por todos estes motivos associados, acabaram por romper em alguns pontos.

- Foram construídas obras de Microdrenagem como: bocas de lobo e caixas de captação em concreto armado e tubulações de $\Phi$ 0,60, 1,20 e 1,50m do tipo PMSP assentados em berço de pedra;

- dissipadores (em peças em concreto armado)

Em 1995, devido eventos de chuvas intensas em Março (651,1 mm mensal) houve um colapso das obras de contenção construídas. Por esta razão estas obras foram reconstruídas e outras foram feitas, como descrito a seguir:

- Demarcação da rede de águas pluviais, abertura mecanizada de valas com profundidade media de 2,30m e preparo do fundo da vala com berço de pedra, novas bocas-de-lobo e caixas de captação foram construídas com concreto armado, tubulação de $\Phi 1,00$ a $1,50 \mathrm{~m}$ de ferro ondulado do tipo ARMCO e dissipadores de energia em concreto armado.

- Os novos cordões de nível (Figura 5.31), não apresentavam espaçamento homogêneo, chegando em alguns casos a ter o dobro da distância entre um cordão e outro. Foram reparados ainda os aterro e aterrados os sulcos $e$ ravinas que surgiram a partir da progressão lateral destas feições.

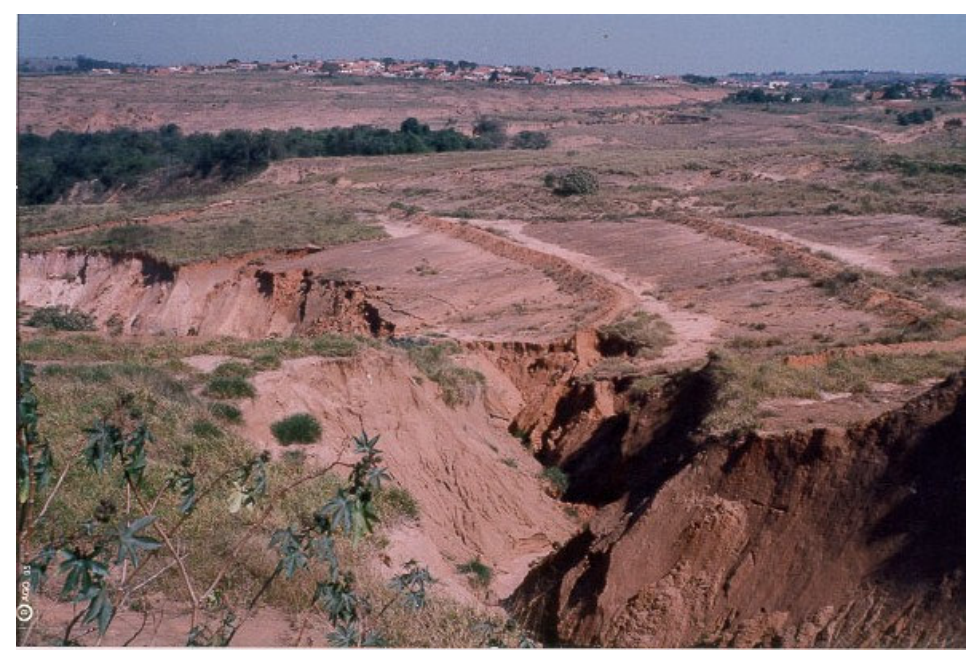

Figura 5.31- observar os cordões de nível rompidos em 1995. 
- Foi construída uma canaleta de aproximadamente $15 \mathrm{~m}$ de extensão, 3,0m de largura e $1 \mathrm{~m}$ de profundidade na cabeceira do canal do Dimas (Figura 5.32).

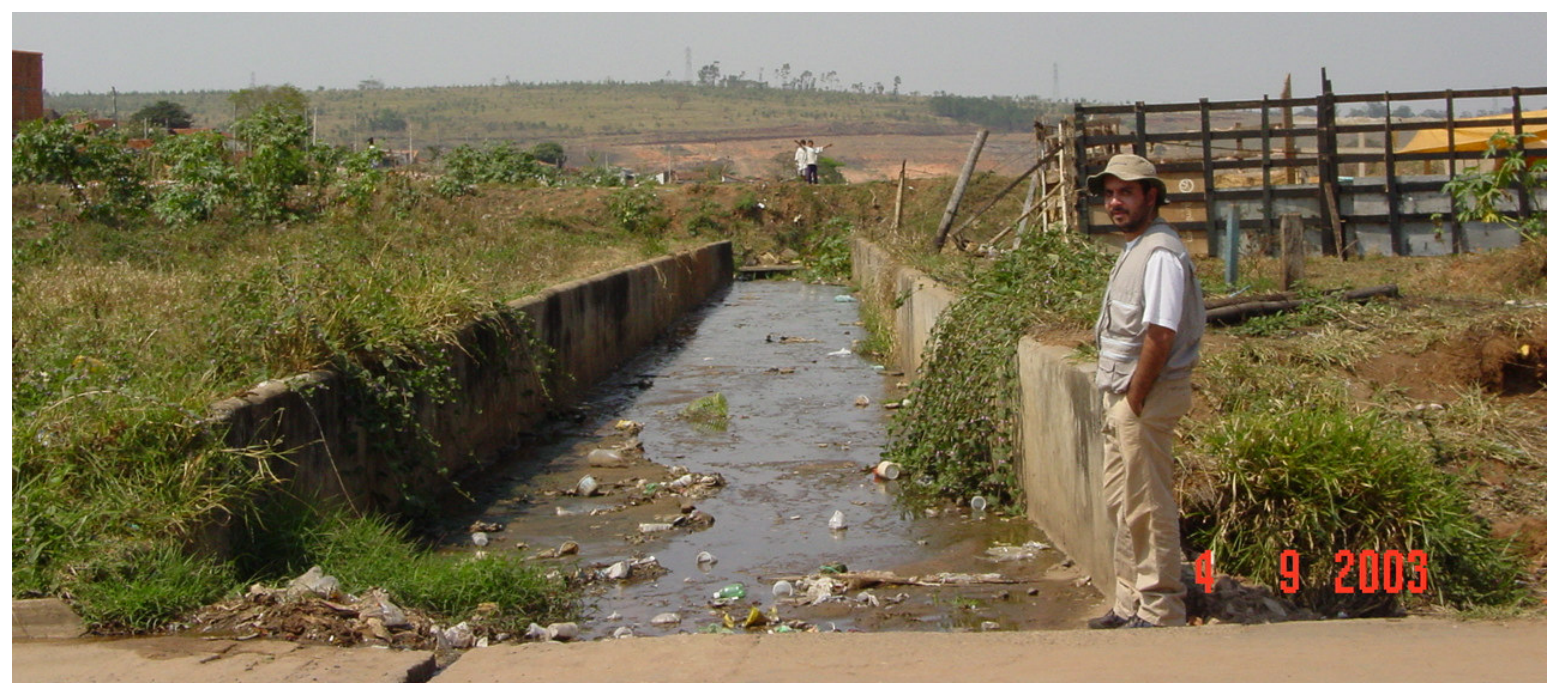

Figura 5.32- observar a canaleta construída no inicio do canal do Dimas, observar que esta acaba levando lixo para a rede de águas pluviais.

- A área da voçoroca da florestal estava sendo aterrada com resíduos sólidos e transformada assim em lixão municipal, causando graves problemas ambientais (perigo de poluição das águas e solo), sociais, proliferação de doenças e catadores de lixo. A Figura 5.33, mostra os impactos gerados por este tipo de procedimento de controle de processos erosivos.

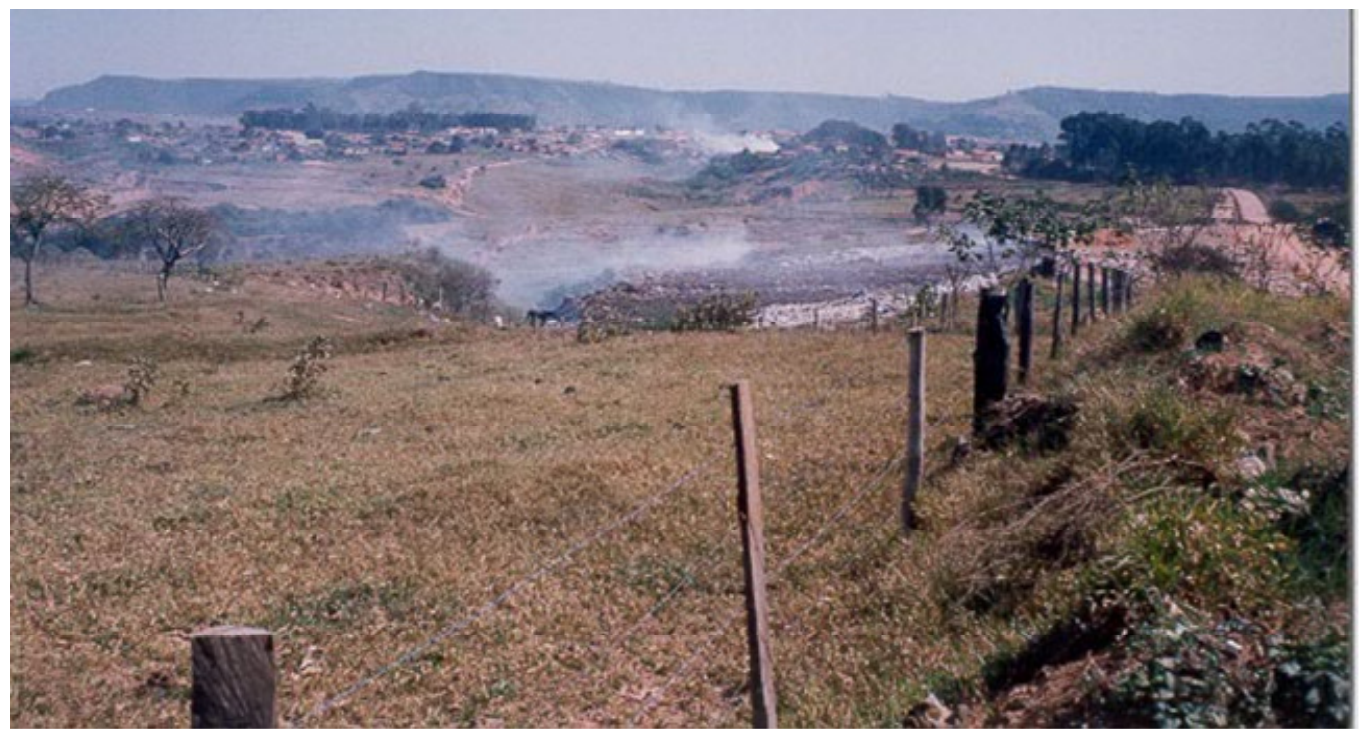

Figura 5.33- observar os impactos ambientais da disposição de resíduos sólidos em feições erosivas, como procedimento de controle.

No dia 24 dezembro de 2000, novo evento de chuva de $124 \mathrm{~mm} /$ dia, provocou o colapso das obras de controle executadas (Figura 5.34). Logo a seguir foram então 
realizadas obras de terraplanagem em regime de emergência para desviar a rede de esgoto e águas pluviais do talvegue da voçoroca e foram consideradas novas obras como:

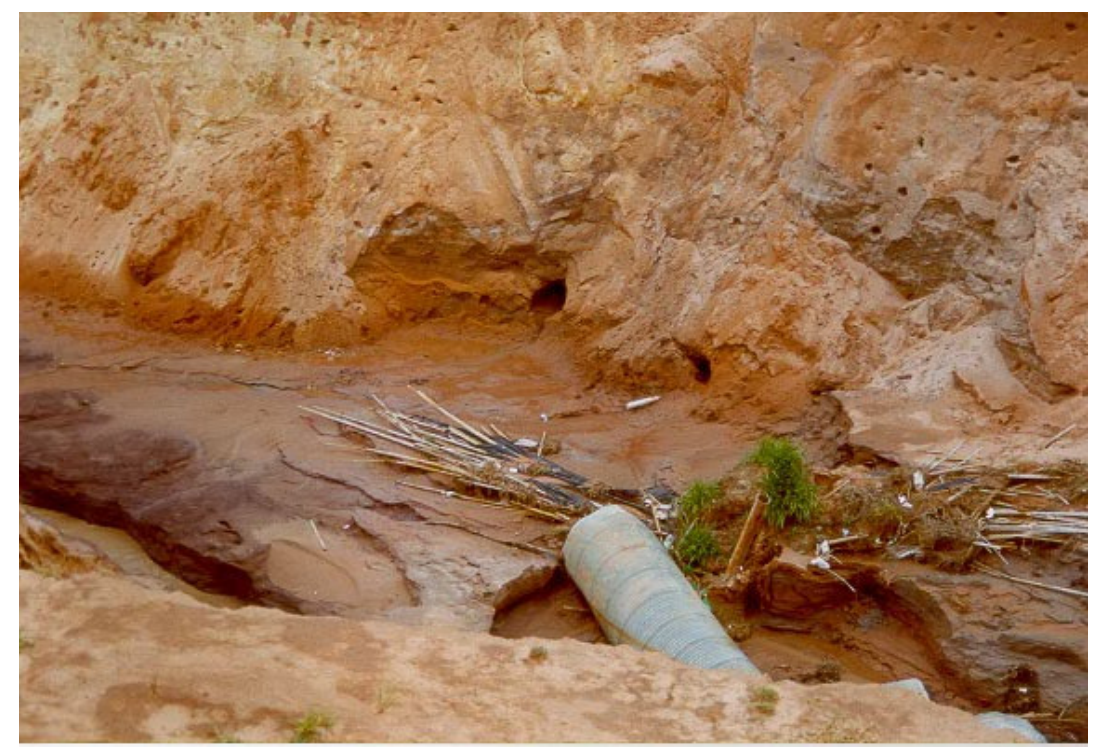

Figura 5.34- observar a tubulação de águas pluviais totalmente destruída, no canal do Dimas em Dezembro de 2000.

- Foram construídas 2 barragens de terra ao longo do canal do Dimas, estas foram feitas com o material R+5 e R+6. Apresentavam altura em torno de $3 m$ e sem nenhuma estrutura para drenar o excesso de água acumulada ou de dissipação de energia.

- Dentre as obras de microdrenagem foram reconstruídas caixas e tubulação (diâmetro de 0,8 - 0,6m) ao longo das encostas do canal do Dimas e Raia para controle das águas pluviais e sua condução até a confluência do Tucum, bocas-de-lobo no início e fim do sistema de captação de águas pluviais e uma vala entre a rua Bandeirante e o primeiro cordão (margem direita do Dimas), para desviar as águas pluviais do canal do Dimas, como observa-se na Figura 5.35. 


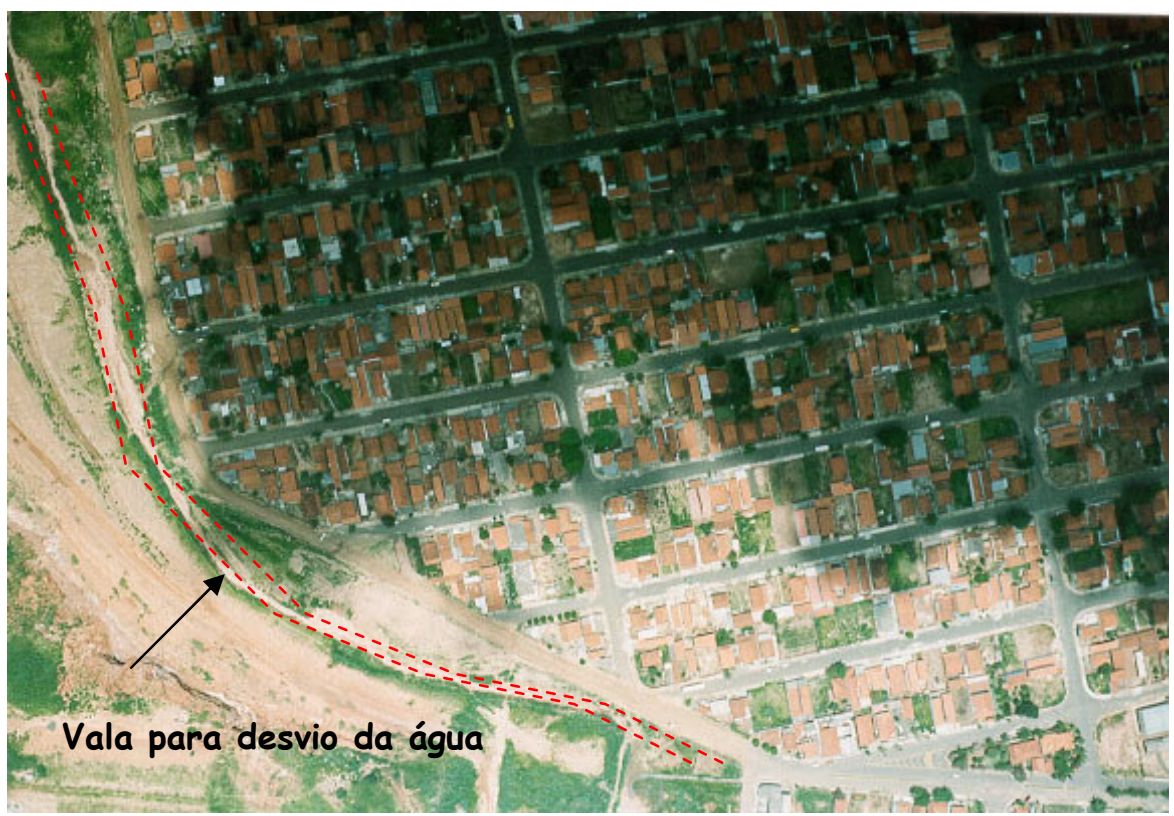

Figura 5.35- Mostra a vala utilizada para desviar o fluxo de águas pluviais do canal do Dimas em 2000.

- As obras de macrodenagem englobaram a reconstrução de escadas hidráulicas no fim dos sistemas de microdrenagem das margens do canal do Dimas, com extensão aproximada de $50 \mathrm{~m}$ do lado direito e $20 \mathrm{~m}$ do lado esquerdo, largura de $1,5 \mathrm{~m}$ e profundidade de $1 \mathrm{~m}$.

- Os cordões foram reconstruídos com material $R+1, R+2, R+3, R+4, R+5$ e R+6, não compactado sobre material retrabalhado compacto.

Estas obras até os dias atuais permanecem sendo reconstruídas, mas nenhuma outra técnica foi aplicada, como mostram as Figuras 5.36 e 5.37.

- Como medidas auxiliares de controle, o lixão foi fechado e desativado e sua área foi aterrada com uma fina camada de solo da própria região;

- Na antiga voçoroca do Raia, ocorreram problemas pelo rompimento da tubulação de drenagem de águas pluviais que passa pela antiga feição, ocasionando solapamento do solo da base e formando uma nova erosão. Mas esta foi logo recuperada;

- A voçoroca do Recanto das Águas foi totalmente aterrada com material retrabalhado de suas encosta e feito uma caixa para condução das águas.

- Os cordões de nível rompem como mostram as figuras (5.36 a e b), mas logo são recuperados, quando tratores que são fornecidos pelo Estado, estão no município, mas quem decide como e onde eles devem ser reconstruídos é o 
tratorista. Mas, em alguns lugares como por exemplo nas encostas do Dimas apresentam-se estáveis :

(a)

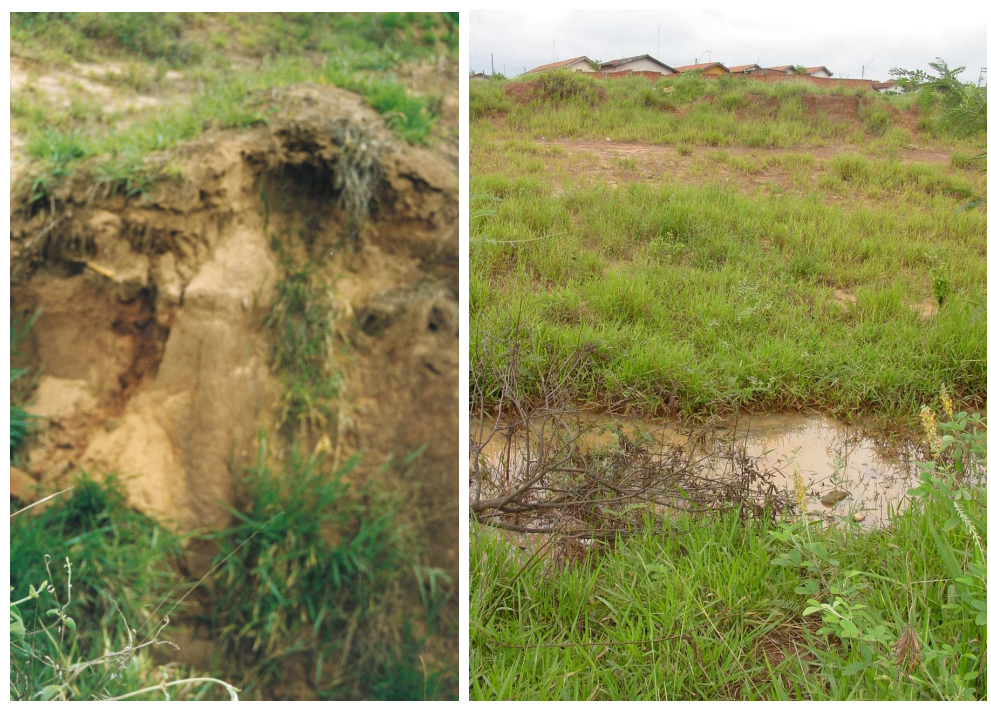

(b)

Figura 5.36- Observar os cordões rompidos (A) e acumulando água (B) no verão de 2004.

- Escadas hidráulicas entram em colapso, mas logo são reconstruídas como mostra a figura 5.36 a e b;

(a)
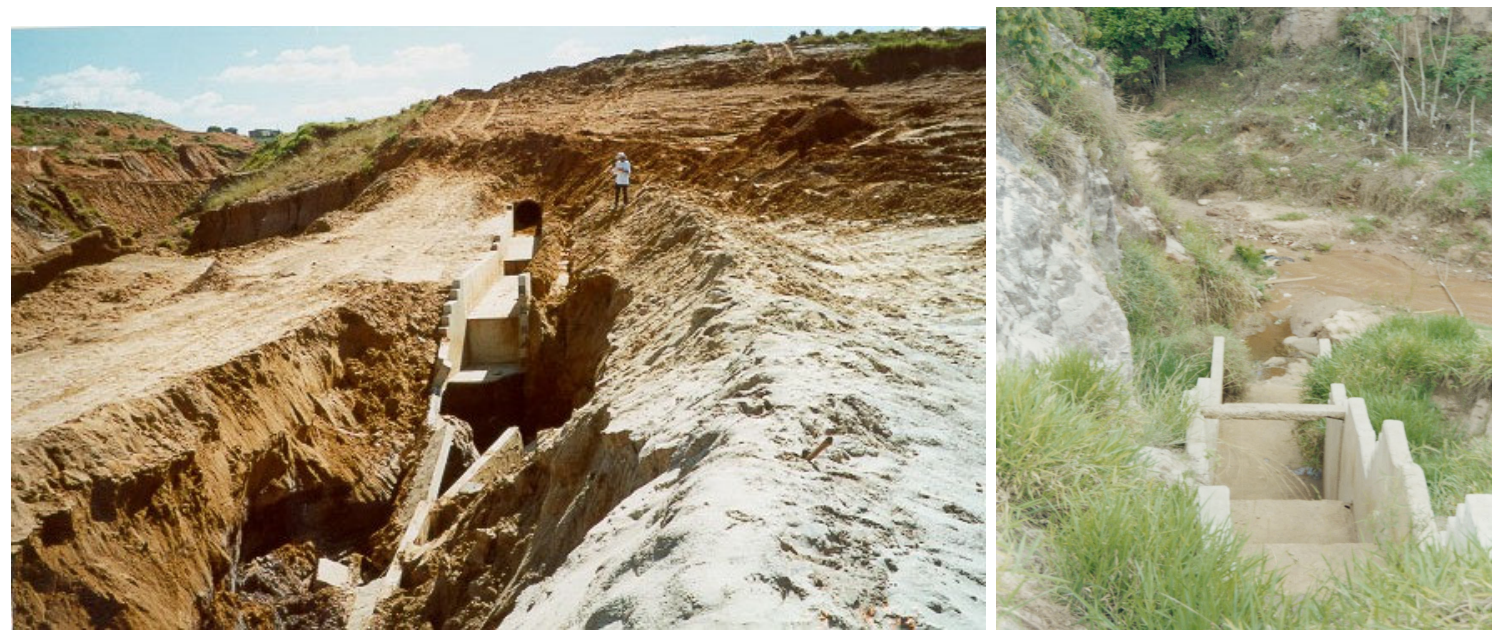

(b)

Figura 5.37- Mostra a escada dissipadora da margem esquerda do Dimas rompida no inverno de 2002 (a) e depois de reconstruída (b).

- As obras de microdrenagem também entram em colapso devido, provavelmente falta de manutenção e solapamento da base em que estão instalados: 


\section{2- CARACTERÍSTICAS PLUVIOMÉTRICAS}

Na Figura 5.38, podemos observar à distribuição media mensal no período de 58 anos (Novembro 1942 a Julho 2000) no município de São Pedro. Neste se observam as grandes taxas pluviométricas mensais nos meses mais chuvosos de novembro a março $e$ revelam ainda que nesta região podem ocorrer, também períodos extremante secos em julho e agosto.

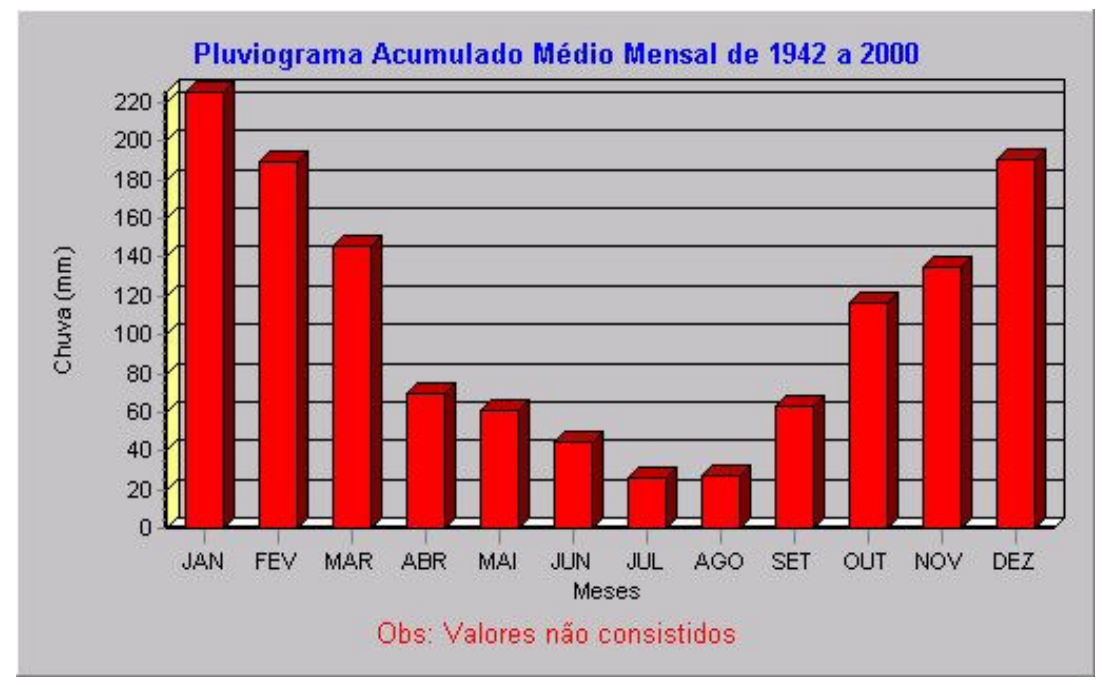

Figura 5.38 - As medias mensais para o período nov 1942 a julho de 2000, SIGRH (www.sigrh.sp.gov.br).

Mas o que influência o processo erosivo em termos de pluviosidade na área, são as chuvas de caráter orográfico. Estas chuvas são características de regiões da depressão periférica, nas proximidade da Serra de São Pedro. Na figura 5.39 podemos observar mais de 41 meses em que choveu acima de $280 \mathrm{~mm}$, estes ocorrem principalmente nos meses de janeiro e fevereiro, caracterizando que, invariavelmente, todos os anos nestes meses temos índices elevados de chuva. O evento mensal acima de $600 \mathrm{~mm}$ destacado na Figura 5.39 ocorreu em março de 1995. Neste mês houve uma reativação descontrolada das feições erosivas presentes na área e o rompimento do aterro por onde passa a estrada SP191, mais precisamente no ponto por onde passa a canalização do córrego do Tucum. 
Totais Mensais do municipio de SãoPedro (Nov1942-Jui2000)

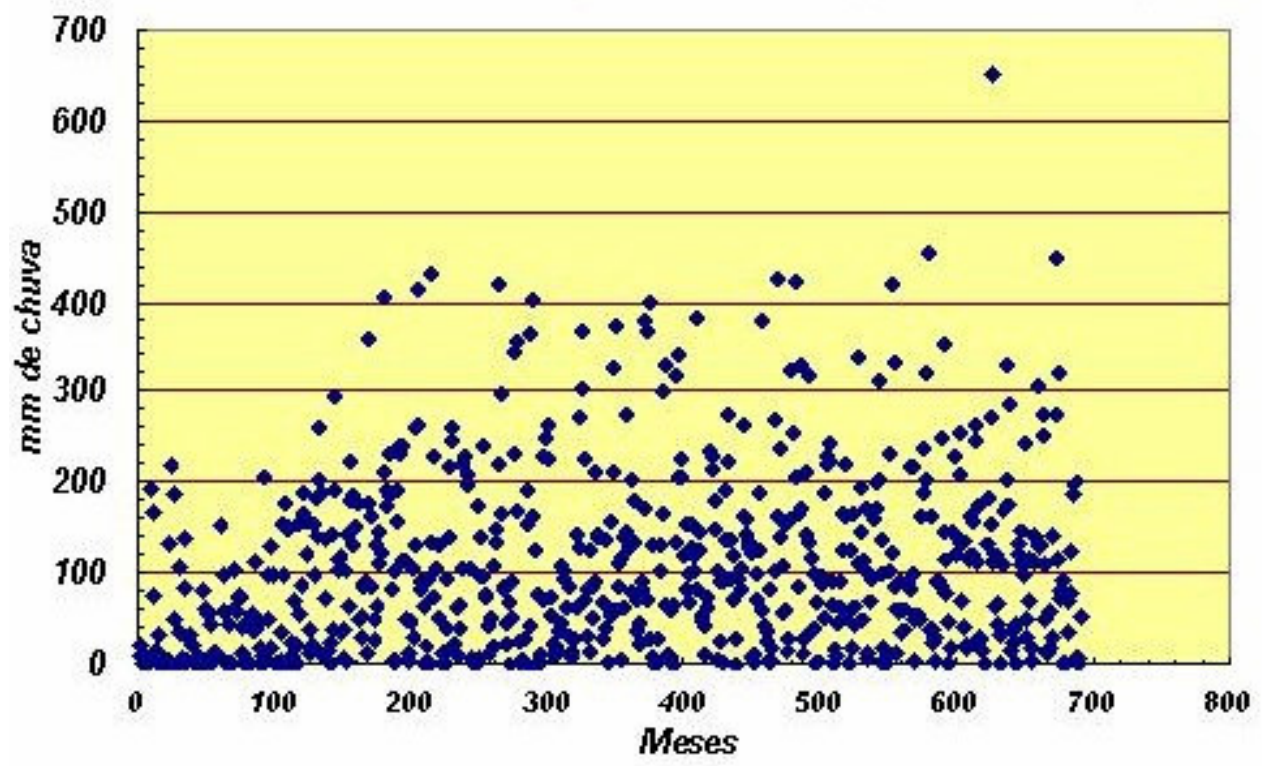

Figura 5.39- Distribuição mensal das chuvas (ao redor 700 meses analisados) SIGRH (www.sigrh.sp.gov.br).

As medias diárias acima de $80 \mathrm{~mm}$, ocorreram aproximadamente 23 vezes ao redor de 21000 medidas durantes 58 anos. Podendo representar que a cada 2 anos nesta região ocorrem pelo menos uma vez por ano chuvas críticas, podendo ocorrer também eventos de chuvas intensas de até $124 \mathrm{~mm}$ por dia como podemos observar na Figura. 5.40. Esta chuva em particular ocorreu em dezembro de 2000. Neste dia ocorreu outro registro de reativação descontrolada das feições, sendo decretado estado de alerta e muitos moradores foram retirados das encostas destas feições. Devido o surgimento de grandes ravinas e desmonte de material das encostas. 
Dados de chuva Diarias de São Pedro de Nov1942 a Jul2000

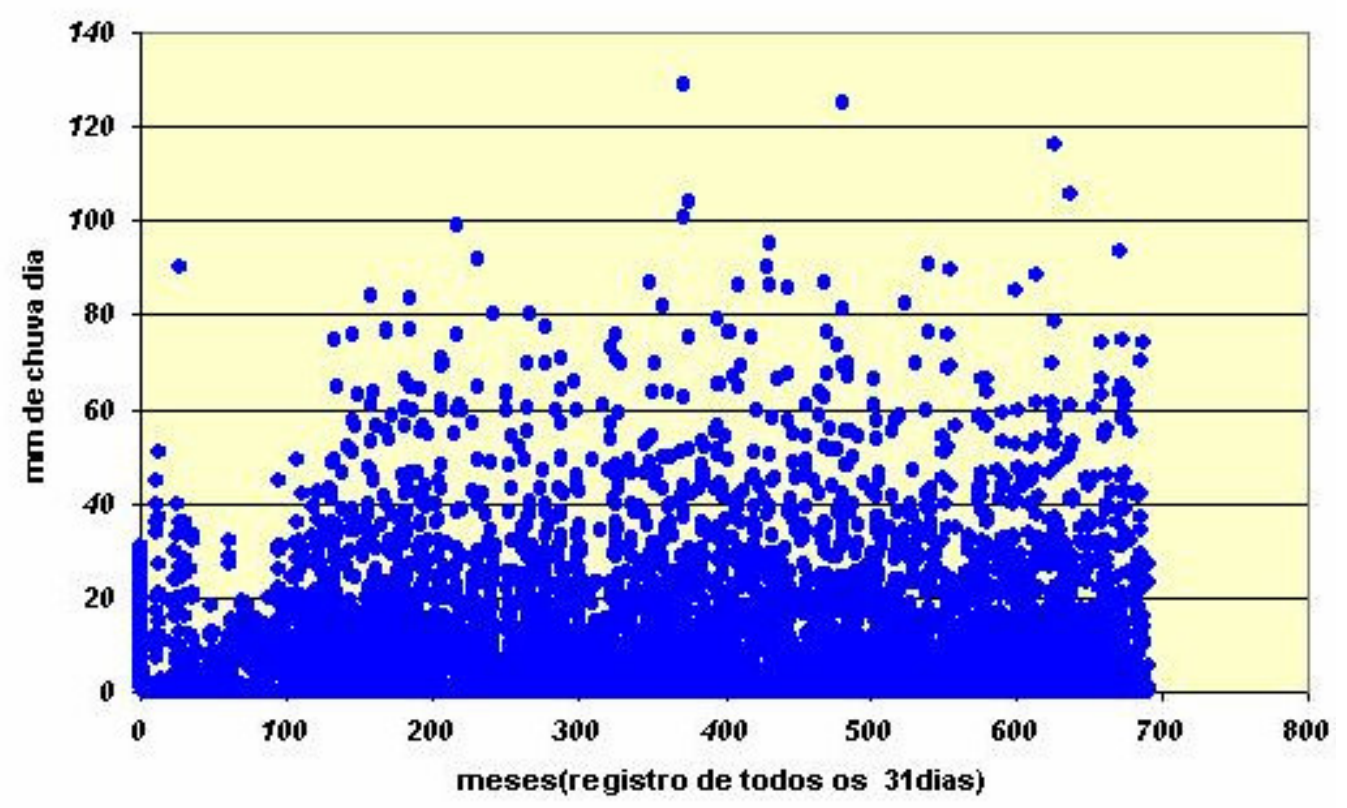

Figura 5.40 - Distribuição das intensidades diárias (ao redor de 21000 medidas) SIGRH (www.sigrh.sp.gov.br) 


\section{DISCUSSÃO DOS RESULTADOS}

\section{1- ASPECTOS PERTINENTES AOS MATERIAIS INCONSOLIDADO}

Os resultados obtidos em ensaios laboratoriais apresentaram similaridade dos parâmetros básicos, assim não foram suficientes para separar os materiais inconsolidados e rochas presentes na área.

Os materiais geológicos da área apresentam predominantemente alta susceptibilidade à erosão, visto que os resultados dos ensaios de erodibilidade apresentaram índice E40 (Pejon, 1992) menor que 1, refletindo também a textura arenosa (areia média e areia fina totalizando até $90 \%$ ) e a pouca expressividade de material fino da ordem de até $15 \%$, assim como o ângulo de atrito e baixa coesão dos ensaios de cisalhamento direto. Para alguns materiais geológicos o índice de erodibilidade foi maior do que 1,devido a presença de matéria orgânica, raízes e seixos, não refletindo seu real comportamento de alta erodibilidade no campo.

Quando da instalação dos processos erosivos grande parte dos materiais residuais estavam recobertos pelos retrabalhados, portanto a deflagração inicial das feições foi instalada a partir dos materiais retrabalhados, e durante parte da "evolução" destas feições as mesmas encontravam-se inteiramente associadas a estes materiais.

Dentre os materiais retrabalhados ocorre uma camada de espessura da ordem de $1 \mathrm{~m}$, com pedrisco (material R+7) e com compactação maior do que os outros (peso especifico seco de $1,8 \mathrm{~g} / \mathrm{cm}^{3}$ e grau de compactação de $96 \%$ ). Esta camada esta posicionada acima dos materiais residuais e deve ter sido um condicionamento importante na propagação das feições erosivas, devido a menor facilidade de infiltração das águas.

\section{2- INFLUÊNCIA DA DECLIVIDADE NO PROCESSO}

Os resultados mostraram que a classe de declividade 1, apresenta terrenos planos ou ligeiramente planos, o que possibilita um escoamento superficial muito lento, não acarretando maiores problemas com relação à erosão. As classes 2 e 3 estão associadas a 
encostas com inclinações muito suaves, com escoamento superficial lento a médio, contudo, a classe 3 apresenta problemas erosivos, devido, principalmente, as características do material geológico presente, visto que nas outras áreas com estas declividades feições erosivas são praticamente inexistentes.

Já as classes 4, 5, 6, 7 e 8 caracterizam-se por terrenos ligeiramente inclinado à inclinados, nos quais o escoamento superficial pode ocorrer de forma rápida, dificultando a infiltração, sendo que este fator associado a materiais geológicos e inconsolidados altamente susceptíveis à erosão, pode provocar a formação de feições erosivas.

\section{3- RELAÇÃO DOS LANDFORMS COM OS PROCESSOS EROSIVOS}

A área é constituída por encostas com perfil misto com combinação entre côncava, convexa e retilínea, e em todas as encostas o terço médio e inferior côncavas-retilíneas foram afetados pelo processo erosivo. Por outro lado o terço superior é predominantemente convexo.

Destaca-se que as principais feições erosivas são de cabeceira e fundo de vale, enquanto que o predomínio das ramificações são de encostas de acordo com a classificação de Brice (1966). Tais condições foram desenvolvidas em função da concentração de águas superficiais em pontos específicos, como nas porções mais elevadas dos talvegues dos canais de drenagem. Tais concentrações foram provocadas pela combinação de landforms e a implantação de obras e outros tipos de uso e ocupação, como a construção da antiga estrada de terra São Pedro- Charqueada e da urbanização.

Pode-se verificar que a feição do São Dimas e do Raia tem seu nível de base próximo do nível de base mínimo da área, que é o canal do córrego do Tucum. Porém, não é o caso da feição e ramificações da Fazenda, que ainda apresentam potencial para propagação em profundidade.

\section{4- USO E OCUPAÇÃO COMO ASPECTOS MODIFICADORES}

As alterações provocadas pela expansão urbana e ampliação da malha viária na bacia desde 1962 até os dias atuais vêm acelerando consideravelmente a ampliação das áreas afetadas pelos processos erosivos.

A retirada da vegetação natural direciona o avanço das feições neste sentido. Assim como a utilização dessas áreas como deposição de resíduos sólidos. 
A ocupação destas encostas afetadas por processos erosivos, pelas populações mais carentes ao longo do tempo, mostrou que, áreas loteadas sem infra-estrutura acabam por agravar ou deflagrar processos erosivos. Como as ravinas em 1988 na encosta do canal do Dimas.

\section{5- ÍNDICES PLUVIOMÉTRICOS E PROCESSOS EROSIVOS}

Um dos fatores climáticos de maior importância na erosão dos solos é a chuva. $O$ volume $e$ a velocidade do escoamento superficial dependem da intensidade, duração $e$ frequiência da chuva. Em São Pedro temos a ocorrência de chuvas com alta intensidade, características de regiões com elevados índices pluviométricos, mas principalmente devido as chuvas orográficas que ocorrem junto as cuestas basálticas nas cabeceiras das bacias. Normalmente, estas chuvas são de curta duração e alta intensidade.

Mesmo considerando as características de infiltração elevada $\left(K \cong 10^{-3} \mathrm{~cm} / \mathrm{s}\right)$, a maioria das chuvas dos 12 eventos, 4 podem produzir escoamento superficial, portanto, agindo como deflagrador. As chuvas ocorrem predominantemente entre os meses de novembro e março.

Analisando o tc nas 19 seções estudadas, observa-se que somente os eventos 8 e 9 de chuva apresentam duração menor que tc máximo obtido para a seção número 8 . Isto significa que tp é muito próximo ou menor que a duração das chuvas. Resultando então que as tubulações devem dar fluxo a vazão de pico por um período longo, vista que, a vazão de pico será mantida, pelo menos, até alguns minutos depois de finalizada a chuva.

Daí a importância de considerar o aumento do diâmetro das tubulações em $40 \%$ conforme o sugerido por diversos autores (Frendrich et al., 1997 e Tucci et al., 2003). É considerado neste trabalho na Tabela 5.9.

\section{6- ANÁLISE DAS TÉCNICAS DE CONTROLE UTILIZADAS}

Observando-se as medidas de controle, verifica-se que algumas caixas de coleta de águas superficiais encontram-se assentadas sobre material residual, porém a grande maioria, envolvendo todos os tipos de obras, encontra-se em interação direta com os materiais retrabalhados.

Em relação aos landforms observa-se que as medidas de controle não foram implantadas respeitando a geometria de cada elemento de terreno que constitui cada landform. 
A análise da evolução histórica realizada nas fotografias aéreas demonstrou que as feições erosivas não foram formadas pela expansão urbana, mas foram agravadas consideravelmente por esta e também pela execução de obras de controle que não levaram em consideração as características geológico-geotécnicas particulares de cada uma destas feições e a dinâmica natural da bacia.

Os cordões de nível, assim como as demais obras executadas não respeitaram os limites de divisores de água e a formas do terreno, ocasionando um acumulo de água $e$ conseqüentemente rompimento destas estruturas.

Os cordões construídos não seguiram o rigor técnico e sua manutenção é executada de forma aleatória. Já as barragens de terra não suportaram o aporte de água acumulada e romperam. As escadas hidráulicas que despejam as águas coletadas pelo sistema de águas pluviais (caixas, tubulação e bocas-de-lobo) na área de confluência do Tucum, mostram-se relativamente eficientes. A terraplanagem e aterramento representam uma constante em toda área, assim a partir do momento em que um sulco ou ravina é formado esta vai sendo aterrada com objetivo de conter sua evolução. A utilização de lixo como aterro mostra-se como uma atividade não adequada para o controle de feições erosivas devido à baixa capacidade de compactação e alta permeabilidade; condição esta que torna o material de baixa estabilidade. Além do que não é uma medida adequada em termos sanitários. As obras de contenção, no geral foram executadas de forma inadequada e as que foram executadas de forma correta, não receberam a manutenção necessária para evitar seu colapso.

Alguns fatores observados para o fracasso das obras de controle foram:

- Terraceamento que não levou em consideração as características naturais da drenagem e em alguns pontos passou a acumular água pluvial, causando rompimentos;

- Terraplanagem manteve rocha alterada e residual aflorando, provocando a intensa e generalizada incidência de erosão laminar e do tipo sulco que evoluía rapidamente para ravinas:

- Dique Marginal construído com material arenoso e sem compactação, ocasionando sua fragilidade em locais onde interceptava o arruamento;

- Diques Internos de forma geral funcionavam bem, mais romperam devido a ineficiência das demais intervenções;

- Drenagem da água subterrânea não foi executada com cuidado e critério técnico. $O$ dimensionamento e construção dos drenos que foram envoltos em plástico 
impermeável, não foram adequados. Este fato provocou um impedimento da coleta das águas e, assim, induziu o escoamento por fora do dreno aumentando o processo erosivo por "piping" e solopamento.

- Aterramento com solo local, restos orgânicos e rocha alterada. Já a feição erosiva da fazenda, continuava sendo aterrada com resíduos sólidos provenientes da coleta seletiva do município de São Pedro.

- Não execução de revegetação, medida de controle essencial em área de retaludamento e terraceamento.

Áreas até então estabilizadas tornam-se alvo de manejo inapropriado, como a retirada da vegetação já desenvolvida e a falta de um critério de acompanhamento técnico das obras de contenção destas feições. As máquinas agrícolas utilizadas nestas obras ficam pelo período de 1 mês em posse do município, que direciona o fechamento das feições que podem sofrer manejo por este tipo de máquina. No entanto, quem decide como e de que forma vão ser reconstruídos os cordões e aterradas as feições em geral é o próprio operador.

\subsection{1- AVALIAÇÃO ECONÔMICA DOS CUSTOS DE OBRAS DE CONTROLE DE EROSÃO URBANA}

$\mathrm{Na}$ área existem poucas ou nenhuma estimativa de custo das obras de controle das feições erosivas da cabeceira do Tucum. Os dados dispersos que foram cadastrados nesta pesquisa dão uma pequena idéia do volume de dinheiro gasto pelo município de São Pedro ao longo do tempo na tentativa de controlar o processo de evolução destas feições. Nos cálculos dos custos das obras, estão contidas apenas obras de drenagem da águas pluviais e reaterro. Sobre as obras de movimentação de terra (corte e aterro) $e$ revegetação não foi possivvel obter informações precisas.

Em 1994 o investimento total na área de $2 \mathrm{Km}^{2}$ foi de $R \$ 256.073,90$ (Tabela 6.1 e 6.2), que foram investidos basicamente na instalação de uma rede de drenagem $e$ recuperação das estradas afetadas, estas obras contabilizam cerda de $R \$ 0,12$ por $\mathrm{m}^{2}$.

Em 1996 o investimento total na área de foi de $R \$ 544.889,88$ (Tabela 6.3), que foram investidos basicamente na instalação de uma nova rede de drenagem, depois dos eventos de chuva de 1995 e reaterro, com gastos de $R \$ 0,27$ por $\mathrm{m}^{2}$. 
Os gastos das obras executadas em 1991 e 1992 e em 2000, assim com as obras de controle continuam sendo executadas, mas não apresentam registro de custos.

Obras de controle de processos erosivos mostram-se ainda muito onerosos para qualquer município, como pode-se observar em São Pedro. Por outro lado podem ser fonte de obtenção de recursos tanto do estado como da união. Pois geralmente quando estão associadas a áreas de risco, possibilitam a liberação rápida de recursos.

Para a recuperação desta área, onde uma nova destinação e uso urbano sejam dados ao local, as obras podem vir a ter custos muito superiores a estes, se considerar a instalação de infra-estrutura urbana para estas áreas como loteamentos, projetos paisagísticos, praças, parques, quadras e outras estruturas urbanas. 
Tabela 6.1- planilha de custo de obras de combate a erosão bairro São Dimas, dados cedidos pela prefeitura municipal de São Pedro-Secretaria de Planejamento.

\begin{tabular}{|c|c|c|c|c|c|}
\hline \multicolumn{6}{|c|}{$\begin{array}{l}\text { Planilha de Custo de Obras } \\
\text { Obra: Drenagem - Rede águas pluviais e Obras Complementares Combate e Erosão }\end{array}$} \\
\hline ITEM & Descrição do Serviço & Quant. & Unid & $\begin{array}{l}\text { Custo Material } \\
\text { Unitário R\$ }\end{array}$ & SUBTotal \\
\hline 01 & Tubo $\varnothing 0,60 \mathrm{~m}$ tipo PMSP ponta e bolsa $C 1$ & 650 & $m$ & 25,00 & $16.250,00$ \\
\hline 02 & $\begin{array}{l}\text { Tubo } \varnothing 1.00 m \text { tipo PMSP ponta e bolsa CA2 } \\
\text { Armada }\end{array}$ & 130 & $m$ & 85,00 & $11.050,00$ \\
\hline 03 & Tubo $\varnothing 1.20 \mathrm{~m}$ tipo PMSP ponta e bolsa CA2 & 200 & $m$ & 117,00 & $23.400,00$ \\
\hline 04 & Tubo $\varnothing 1.50 m$ tipo PMSP & 250 & $m$ & 178,00 & $44.500,00$ \\
\hline 05 & Bocas de lobo alvenaria estrutural tampos $F^{\circ}-F^{\circ}$ & 08 & unid & 228,50 & $1.828,00$ \\
\hline 06 & Poço de visita - Alvenaria estrutural tampos $F^{\circ} F^{\circ}-$ & 05 & unid & $1.294,18$ & $6.470,90$ \\
\hline 07 & Canaleta $\frac{1}{2}$ tubo Tubo $\varnothing 0,60 \mathrm{~m}$ & 200 & $m$ & 16,00 & 3.200 .00 \\
\hline \multicolumn{4}{|c|}{ TOTAL } & \multicolumn{2}{|c|}{$R \$ 106.698,90$} \\
\hline \multicolumn{4}{|c|}{ OBS: Custo somente de materiais } & \multicolumn{2}{|c|}{ Data confecção 26/07/94 } \\
\hline
\end{tabular}


Tabela 6.2 - planilha de custo de obras de combate a erosão bairro São Dimas, dados cedidos pela prefeitura municipal de São PedroSecretaria de Planejamento.

\begin{tabular}{|c|c|c|c|c|c|}
\hline \multicolumn{6}{|c|}{$\begin{array}{l}\text { Planilha de Custo de Obras } \\
\text { Obra: Rede para Drenagem de águas pluviais - Recuperação de área Erodida- Bairro Recanto das águas e São Dimas }\end{array}$} \\
\hline ITEM & Descrição do Serviço & Quant. & Unid & $\begin{array}{l}\text { Custo Material } \\
\text { Unitário R\$ }\end{array}$ & SUBTotal \\
\hline 1.0 & Infra-estrutura & & & & \\
\hline 1.1 & Abertura Mecanizada de valas com profundidade media de 2.30 & 1863 & $m^{3}$ & 13,20 & $47.968,80$ \\
\hline 1.2 & Demarcação da rede & 1580 & $m$ & 2,90 & $4.582,00$ \\
\hline 1.3 & Preparo do fundo da vala com berço de pedra 3 & 2850 & $m^{2}$ & 5,70 & $16.245,00$ \\
\hline 2.0 & Obras de Drenagem & & & & \\
\hline 2.1 & Boca de lobo tipo PMSP com grelha F-F- concreto armado & 06 & unid & 350,00 & $2.100,00$ \\
\hline 2.2 & Caixa captação concreto armado & 05 & unid & 390,00 & $1.950,00$ \\
\hline 2.3 & Tubulação $\varnothing 1.50$ Ferro ondulado tipo ARMCO & 1.380 & m & 231,63 & $319.649,40$ \\
\hline 2.4 & Tubulação Armco $\varnothing 1.00$ Ferro ondulado tipo ARMCO & 200 & m & 178,25 & $35.650,00$ \\
\hline 2.5 & Dissipadores peças em concreto armado & 400 & $m$ & 270,00 & $108.000,00$ \\
\hline 3 & Recuperação Aterro & & & & \\
\hline 3.1 & Reaterro com apiloamento mecanizado & 552 & $m^{3}$ & 15,84 & $8.743,68$ \\
\hline \multicolumn{4}{|c|}{ TOTAL GERAL } & \multicolumn{2}{|c|}{$R \$ 544.889,88$} \\
\hline \multicolumn{4}{|c|}{ OBS: Custo somente de materiais } & \multicolumn{2}{|c|}{ Data confeç̧ão 17/01/96 } \\
\hline
\end{tabular}


Tabela 6.3 - planilha de custo de obras de combate a erosão bairro São Dimas, dados cedidos pela prefeitura municipal de São PedroSecretaria de Planejamento.

\begin{tabular}{|c|c|c|c|c|c|c|}
\hline \multicolumn{7}{|c|}{$\begin{array}{l}\text { Planilha de Custo de Obras } \\
\text { Obra: Drenagem - Rede águas pluviais e Obras Complementares Combate e Erosão }\end{array}$} \\
\hline ITEM & Descrição do Serviço & Quant. & Unid & $\begin{array}{l}\text { Mão de } \\
\text { Obra/Serviços }\end{array}$ & $\begin{array}{l}\text { Custo Material } \\
\text { Unitário } R \$\end{array}$ & SUBTotal \\
\hline 1.0 & Infra-estrutura & & & & & \\
\hline 1.1 & Abertura Mecanizada de valas com profundidade media de 1.80 & 3320 & $m^{3}$ & 9.857 & & 9.857 \\
\hline 1.2 & Acerto e preparo do terreno & 2.460 & $m^{2}$ & 984 & & 984 \\
\hline 1.3 & Preparo do fundo da vala com berço de pedra 3 & 1.230 & $\mathrm{~m}^{2}$ & 2.337 & 3.444 & 5.781 \\
\hline 2.0 & Alvenaria-Tubulação & & & & & \\
\hline 2.1 & Boca de lobo tipo PMSP com grelha $F^{\circ} F^{\circ}-$ & 07 & unid & 1.169 & 2.599 & 3.768 \\
\hline 2.2 & $\begin{array}{l}\text { Poços de visita em alvenaria armada com tampos } F^{\circ} F^{\circ}-\text { tipo } \\
\text { PMSP }\end{array}$ & 07 & unid & 2.026 & 3.795 & 5.818 \\
\hline 2.3 & Tubulação $\varnothing 1.00 \mathrm{~m}$ classe EA-2 conf NBR 9794/87 & 1.230 & $m$ & 4.206 & 109.665 & 113.871 \\
\hline 3 & Recuperação Aterro & & & & & \\
\hline 3.1 & Reaterro com apiloamento mecanizado & 2.100 & $m^{3}$ & 8.424 & & 8.424 \\
\hline 3.2 & Recuperação das vias afetadas & 400 & $m^{2}$ & 872 & & 8.72 \\
\hline \multicolumn{4}{|c|}{ TOTAL GERAL } & \multicolumn{3}{|c|}{$R \$ 149.375,00$} \\
\hline \multicolumn{4}{|c|}{ OBS: Custo somente de materiais } & \multicolumn{3}{|c|}{ Data confecção 26/07/94 } \\
\hline
\end{tabular}




\subsection{2- AVALIAÇÃO AMBIENTAL E EFICIÊNCIA DAS OBRAS DE CONTROLE DE EROSÃO URBANA}

Dentre os diversos impactos ambientais negativos gerados pelas técnicas de controle utilizadas nas cabeceiras do Tucum vale ressaltar que estas apresentaram aspectos positivos e negativos, dependendo principalmente da forma de implantação e de sua manutenção.

As técnicas de controle aplicadas foram basicamente: aterramento, barramento, retaludamento, cordões de nível (terraceamento), Microdrenagem (galerias, bocas de lobo, bueiros (caixas), etc..) e macrodrenagem (escadas hidráulicas, canaleta e canal artificial do tipo vala), drenos de bambu e revegetação (reflorestamento com eucalipto e pastagem) e como medida de controle Lixo.

As obras de Microdrenagem, retaludamento, cordões de nível e aterramento aplicados no canal da favela Raia, apresentaram associados impactos positivos, tendo em vista que hoje as feições que se encontravam no entorno desta área estão controladas. Em alguns pontos pode-se verificar acúmulo de água entre cordões, mais no geral a região apresenta um aspecto visual muito melhor do que antes da aplicação das técnicas de controle.

Outro local com impacto positivo é o da fazenda Florestal, onde havia a ocorrência de ravinas e concentrações de sulcos que foram controladas e até hoje permanecem estáveis após a construção de cordões de nível e revegetação com eucalipto.

Áreas que sofreram aterramento com lixo na fazenda, florestal e cabeceira do Dimas, mostram-se como impactos extremamente negativos. Tendo em vista os efeitos ocasionados por essa prática como:

- Impacto visual;

- Provável contaminação do solo e das águas superficiais e subsuperficiais, devido às características geotécnicas do solo e a não utilização de nenhuma forma de impermeabilização;

- Proliferação de doenças de circulação hídrica e aérea;

Outro impacto negativo foi à utilização de drenos de bambu envoltos em plástico, que acabaram formando piping e agravaram o processo erosivo. Isso porque a água percolava por fora do dreno. 
Aspectos ambientais negativos ocorreram nas obras de microdrenagem como galerias, caixas e etc. Visto que quando rompem devido a dimensionamento e manutenção inadequados acabaram por causar reativação das feições. A seguir vamos descrever alguns desses exemplos:

- Caixa de coleta de águas pluviais, construída na voçoroca do recanto das águas para drenar as águas pluviais depois que a mesma foi aterrada, apresentava-se projetada de forma incorreta, ocasionando o acumulo de água em um ponto mais elevado, provocando o trincamento do aterro na posição oposta.

- As caixas de coleta do canal do Dimas apresentaram problemas devido a falta de manutenção, que acarretou o acumulo de lixo e rompimento a montante.

Quanto as galerias em especial foram executadas 3 projetos a partir de 1994 (Anexo VII), descritos a seguir:

O primeiro em 1994 no canal do Dimas e do Raia com tubulações de concreto de $1 \mathrm{~m}$ de diâmetro, que se romperam no ano de 1995 quando das intensas chuvas de março $(625 \mathrm{~mm} / \mathrm{mês})$.

O segundo, no ano de 1996, com tubulação de ferro corrugado com 1,5m de diâmetro no canal do Dimas e 1,0m no Raia que vieram a romper em dezembro de 2000, fruto da interligação do sistema de esgoto nos tubos provocando corrosão nas conexões.

Já o terceiro, no ano de 2001, as galerias tinham tubos de 0,8m de diâmetro foram colocadas nas encostas do Dimas e de 1m no canal do Raia. As tubulações das encostas do Dimas romperam-se diversas vezes, e a do Raia rompem-se em janeiro de 2003.

Considerando as vazões de pico calculadas neste trabalho e os respectivos diâmetros necessários para conduzir as vazões de pico, constata-se que os diâmetros calculados $e$ implantados estão subdimensionados. Outro ponto a considerar foi 0 rompimento do aterro da estrada São -Pedro Charqueada, no ano de 1995. Nesta época o diâmetro da tubulação era inferior a $2 \mathrm{~m}$, que comparado como cálculo neste trabalho (Tabela 5.9, seção 8 ) da ordem de 3m, também estava subdmensionado.

Atualmente há uma galeria com mais de $3 m$ de diâmetro, e não tem ocorrido problema para dar fluxo a vazão máxima de pico de $40 \mathrm{~m}^{3} / \mathrm{s}$.

O rompimento das tubulações instaladas na encosta do Dimas esta relacionado a 4 motivos: 
1- Devido ao subdimensionamento as tubulações funcionam em seção total, gerando um acúmulo de água nas caixas a montante, é portanto uma carga hidráulica alta;

2- Não há um alinhamento entre as tubulações e as escadas de dissipação;

3- Outro aspecto a considerar no rompimento das tubulações é o acumulo de lixo trazido pelas águas, com diferentes dimensões;

4- Nas implantações não foi considerada a textura arenosa dos materiais geológicos, e portanto os problemas associados a finalização das obras.

Atualmente, o diâmetro da tubulação atual do Raia, da ordem de $1 \mathrm{~m}$, esta pouco abaixo do dimensionamento calculado neste trabalho e tem o lançamento das águas diretamente no canal do Tucum. Tal condição vem levando a um número menor de rompimento do que no Dimas, que mesmo na seção 1 (a mais a montante) já apresenta uma vazão superior a máxima do Raia.

Considerando as características geométricas da bacia, com forma coletora, e com a geração dos maiores volumes na porção a montante, a condição mais adequada seria evitar a concentração destas águas, basicamente em 3 canais na porção jusante, com a implantação de galerias a partir da montante. Desta maneira, ter-se-ia um maior controle do fluxo das águas.

Considerando, este aspecto, as galerias estão posicionadas inadequadamente, visto que estão instaladas na porção jusante.

\section{7- EVOLUÇÃO DAS FEIÇÕES E USO E OCUPAÇÃO}

Com base nas fotografias aéreas e nos registros, a evolução das feições erosivas foi dividida em três estágios, assim caracterizados como: $1^{\circ}$ Estágio (desenvolvimento das feições pré 1962), $2^{\circ}$ Estágio (efeitos da expansão urbana na evolução das feições $1962-$ 1988) e $3^{\circ}$ Estágio (efeitos das obras na área dentro do contexto da evolução 1988-2003).

A definição das diversas formas de uso e ocupação do solo são úteis para subsidiar instrumentos técnicos de planejamento e gestão territorial. Pois considerando-se as características do meio físico em que estão inseridos, as formas de uso e ocupação e a maneira que são executadas podem desencadear diversos problemas.

Entende-se como uso e ocupação as diversas formas de intervenção do homem no meio físico, visando atender as suas necessidades. Mas isso pode resultar tanto em benefícios quanto em problemas, pois geralmente o homem ultrapassa os limites do meio 
físico de absorver estas transformações, desencadeando diversos problemas ambientais $e$ socioeconômicos.

As formas de uso e ocupação são individualizadas em função das modificações que estas causam ao meio e são detalhadas de maneira maior ou menor em função da necessidade solicitada do trabalho em questão e da escala.

Um dos atributos que podem deflagrar os processos erosivos elou acelerar é a ação antrópica, que pode ser avaliada através das diversas formas de uso e ocupação da área que apresentam feições erosivas ou susceptibilidade a ocorrência desde tipo de processo.

$\mathrm{Na}$ cabeceira do córrego do Tucum existe uma diversidade de formas de uso e ocupação do solo, as categoriais de formas de uso e ocupação utilizadas neste trabalho foram definidas por Almeida \& Freitas (1996), que constam da Tabela 6.4.

A metodologia utilizada para delimitar e caracterizar as diversas formas de uso $e$ ocupação, foi a identificação em fotografias aéreas de 1962, 1972, 1978, 1988, 1995 e 2000 e delimitação nas mesmas.

TABELA 6.4 - Categorias de formas de uso e ocupação do solo e problemas/ processos do meio físico segundo Almeida \& Freitas (1996).

\begin{tabular}{|c|c|c|}
\hline $\begin{array}{l}\text { PRINCIPAIS FORMAS DE } \\
\text { USO E OCUPAÇÃO }\end{array}$ & CARACTERÍSTICAS & PROBLEMAS/PROCESSOS DO MEIO FÍSICO \\
\hline Cobertura vegetal natural & $\begin{array}{l}\text { Inclui áreas cobertas principalmente por mata e } \\
\text { capoeira. Nas áreas urbanas encontram-se em } \\
\text { áreas restritas, onde o relevo é mais energético } \\
\text { ou nas áreas de preservação. }\end{array}$ & $\begin{array}{l}\text { Esta forma de uso exerce ação protetora em } \\
\text { relação aos processos de movimento de massa. }\end{array}$ \\
\hline Reflorestamento & $\begin{array}{l}\text { Áreas de recomposição da cobertura vegetal, em } \\
\text { sua maioria para fins econômicos. }\end{array}$ & $\begin{array}{l}\text { Atua de maneira semelhante às matas, } \\
\text { diferenciando-se quanto ao manejo. }\end{array}$ \\
\hline Campo antrópico/Pastagem & $\begin{array}{l}\text { Áreas onde predominam vegetação herbácea, } \\
\text { com alguns arbustos e árvores esparsas. } \\
\text { localizam-se próximos às áreas rurais ou de } \\
\text { expansão urbana. }\end{array}$ & $\begin{array}{l}\text { Quando em relevo mais movimentado e em casos } \\
\text { de exposição do solo, podem ocorrer processos } \\
\text { erosivos. }\end{array}$ \\
\hline Áreas agrícolas & $\begin{array}{l}\text { Áreas destinadas a cultivos perenes ou } \\
\text { temporários (ciclo estabelecido). Nas áreas } \\
\text { urbanas destacam-se a horticultura e as } \\
\text { chácaras rurais (que destinam parte dos lotes a } \\
\text { pequenos cultivos). }\end{array}$ & $\begin{array}{l}\text { Possibilidade de ocasionar ou agravar processos } \\
\text { erosivos quando há exposição dos solos, e em } \\
\text { situações com concentração de drenagem } \\
\text { superficial, com conseqüente assoreamento dos } \\
\text { cursos d'águas. Também o manejo inadequado do } \\
\text { solo e o uso intensivo de fertilizantes e } \\
\text { pesticida podem gerar poluição dos recursos } \\
\text { hídricos, perda de fertilidade do solo, e } \\
\text { esgotamento do solo por determinadas culturas. }\end{array}$ \\
\hline Área urbana consolidada & $\begin{array}{l}\text { Caracteriza-se por ser densamente ocupada, e } \\
\text { pela disponibilidade de infra-estrutura básica e } \\
\text { equipamentos, atividades de comércio e serviços, } \\
\text { etc. }\end{array}$ & $\begin{array}{l}\text { por serem áreas com pouca exposição do solo e } \\
\text { bastante impermeabilizadas possibilitam maior } \\
\text { escoamento superficial, e concentração das } \\
\text { águas, estrangulando alguns sistemas de } \\
\text { drenagem, e intensificado as inundações e os } \\
\text { alagamentos. }\end{array}$ \\
\hline $\begin{array}{c}\text { Área urbana em } \\
\text { consolidação }\end{array}$ & $\begin{array}{l}\text { Constitui áreas com densidade de ocupação } \\
\text { média/alta, apresentando ainda alguns vazios } \\
\text { urbanos, e infra-estrutura e equipamentos }\end{array}$ & $\begin{array}{l}\text { Na fase de implantação de loteamentos, os solos } \\
\text { são expostos à erosão. A implantação parcial de } \\
\text { infra-estrutura (drenagem e pavimentação), com }\end{array}$ \\
\hline
\end{tabular}




\begin{tabular}{|c|c|c|}
\hline & $\begin{array}{l}\text { restritos. Destacam-se nessas áreas grandes } \\
\text { loteamentos e sistemas de autoconstrução. }\end{array}$ & $\begin{array}{l}\text { a concentração e o lançamento de águas de } \\
\text { chuva e servidas, favorece a ocorrência d } \\
\text { boçorocas. Ocorrem também os assoreamentos } \\
\text { das drenagens por resíduos urbanos (lixo, } \\
\text { materiais de construção, etc), e inundações e } \\
\text { problemas de saneamento. }\end{array}$ \\
\hline Área urbana parcelada & $\begin{array}{l}\text { Corresponde à ocupação periférica de densidade } \\
\text { média/baixa, caracterizada por loteamentos em } \\
\text { implantação destinados à classe social menos } \\
\text { favorecida, em que há falta de infra-estrutura e } \\
\text { equipamentos urbanos. }\end{array}$ & $\begin{array}{l}\text { Os problemas são semelhantes aos anteriores, } \\
\text { porém com maior grau de intensidade. }\end{array}$ \\
\hline Favelas & $\begin{array}{l}\text { Habitações precárias, instaladas ao longo dos } \\
\text { córregos ou em encostas, sem infra-estrutura } \\
\text { básica (saneamento de água, esgotos, etc). }\end{array}$ & $\begin{array}{l}\text { Nas encostas, o lançamento de lixo e de águas } \\
\text { servido causa instabilidade com possibilidade de } \\
\text { escorregamentos. Nas baixadas, poluição dos } \\
\text { córregos com lixo e lançamentos de águas } \\
\text { servidas, assoreamento e inundação. }\end{array}$ \\
\hline Mineração & $\begin{array}{l}\text { Compreende os vários tipos de exploração } \\
\text { mineral (areia, argila, turfa, brita, calcário, etc) } \\
\text { em suas diferentes formas de desmonte } \\
\text { (hidráulico, mecânico e com explosivos). Além de } \\
\text { serem diferenciadas se estão em atividades ou } \\
\text { não. }\end{array}$ & $\begin{array}{l}\text { Estas atividades ocasionam devastação tanto no } \\
\text { local como em áreas adjacentes, expondo os } \\
\text { solos a processos erosivos; assoreamento dos } \\
\text { cursos d'água; poluição química das águas pelos } \\
\text { materiais em suspensão; poluição atmosférica } \\
\text { (gases, pó-secagem), sonora (explosivos, } \\
\text { desmontes- ruídos), e dos solos (disposição de } \\
\text { rejeitos). }\end{array}$ \\
\hline Áreas industriais & $\begin{array}{l}\text { São especificadas quanto aos tipos de atividades } \\
\text { que possam causar danos ao meio ambiente, como } \\
\text { poluentes atmosféricos, do solo e hídricos. }\end{array}$ & $\begin{array}{l}\text { Na fase de implantação, expõem extensas áreas } \\
\text { à erosão; no seu funcionamento pode provocar } \\
\text { poluição dos recursos hídricos por lançamento } \\
\text { direto dos rejeitos, poluição atmosférica e do } \\
\text { solo. }\end{array}$ \\
\hline Disposição de resíduos & $\begin{array}{l}\text { Locais para destinação final do lixo urbano, na } \\
\text { forma de aterro sanitário, lixão ou aterro } \\
\text { controlado. }\end{array}$ & $\begin{array}{l}\text { Se não executada com critérios e conforme } \\
\text { normas específicas, podem ocasionar poluição do } \\
\text { solo, das águas superficiais e do lençol freático. }\end{array}$ \\
\hline Gasodutos/Oleodutos & $\begin{array}{l}\text { Sistemas de dutos para transporte de petróleo e } \\
\text { derivados a grandes distâncias. }\end{array}$ & $\begin{array}{l}\text { Na execução da obra em terrenos de relevo mais } \\
\text { movimentado, podem induzir à ocorrência de } \\
\text { escorregamentos. No funcionamento, } \\
\text { apresentam riscos de explosão, vazamentos. }\end{array}$ \\
\hline Sistema viário & $\begin{array}{l}\text { Vias de comunicação na malha urbana ou para } \\
\text { ligação entre áreas distantes } \\
\text { (rodovias,ferrovias). }\end{array}$ & $\begin{array}{l}\text { Para sua implantação ocasionam desmatamentos } \\
\text { com desencadeamento de movimento de massa. a } \\
\text { concentração e o lançamento inadequado das } \\
\text { águas superficiais de drenagem de rodovias } \\
\text { podem intensificar estes processos erosivos } \\
\text { (boçorocas, corridas de massa). }\end{array}$ \\
\hline
\end{tabular}

\section{As principais formas de uso e ocupação identificadas nas cabeceiras do córrego do}

Tucum foram as seguintes: cobertura vegetal natural, reflorestamento, campo antrópico/ pastagem, área urbana consolidada, área urbana em consolidação, área urbana parcelada, favelas, disposição de resíduos e sistema viário. 


\section{$1^{\circ}$ Estágio (Pré 1962)}

A partir do trabalho de fotointerpretação, verificou-se que no ano 1962 havia 3 voçorocas de cabeceira de drenagem na área, de grande porte e um grupo de ramificações(Figura 6.1a).

O primeiro estágio de evolução pode ser caracterizado como efeito de um conjunto de fatores condicionantes e deflagradores que agiram conjuntamente para formação destas feições. Estas foram formadas a partir da concentração de um volume maior de água ocasionado pelas mudanças no relevo associadas a construção da estrada de terra São Pedro-Charqueada e ao desmatamento da área. Estes dois fatores criaram pontos de concentração de águas pluviais que, provavelmente, deflagraram o processo. Estas feições representam uma tentativa de reequilíbrio, considerando o novo regime de vazões $e$ as características da área. Um conjunto de fatores foi responsável pelo surgimento destas feições, destacando-se a diminuição do tempo de pico, associado a um conjunto de fatores predisponentes tais como: cabeceira de bacia coletora com alta declividade e materiais geológicos altamente susceptíveis a erosão.

Em 1962 o uso era basicamente de áreas agrícolas (chácaras, sítios e fazendas), pastagem, sistema viário e áreas de cobertura vegetal natural, sendo que o último ocorria principalmente em encosta com alta declividade e próximo aos canais de drenagem. A expansão urbana ocorria de forma lenta, tanto que na área que abrange a cabeceira da bacia do córrego do Tucum não havia nenhum registro de área urbana.

\section{Estágio (1962-1995)}

\section{De 1962-1978}

Fato importante a ser observado é que este novo estágio evolutivo caracteriza-se principalmente pelo aumento do número de ramificações destas feições e pela progressão lateral e vertical das existentes. Ocorre a concentração das águas pluviais e servidas na cabeceira do referido córrego, causada pela expansão urbana, aumentando as vazões e produzindo alterações nas feições pré-existentes, assim como ocasionando o surgimento de novas feições. Isto fica evidenciado nas fotografias áreas de 1972, ao comparar as formas de uso e ocupação do meio físico dos anos de 1962 e 1972, nota-se que houve muitas mudanças nestes 10 anos. 
Em 1972 ocorreram mudanças importantes como a ampliação do sistema viário, como a construção da SP-191, este fato provocou impactos ambientais negativos no contexto hidrológico desta bacia. Ocorreu ainda uma diminuição da área com cobertura vegetal natural e iniciado o processo de reflorestamento (Figura 6.1b). Neste ano ainda verifica-se o inicio da expansão urbana em direção a bacia, com o parcelamento do terreno na forma de lotes, na encosta esquerda do canal do Dimas, onde hoje fica o bairro que leva seu nome.

As Figuras, 6.1b e 6.1c, mostram que comparativamente em 6 anos de 1972 a 1978, houve uma eclosão da ocupação da bacia. Em 1978 observa-se que o lado direito do canal do Dimas encontrava-se totalmente parcelado em lotes, onde hoje fica o bairro Recanto das Águas. Vale frisar que até mesmo as áreas ocupadas com chácaras e sítios apresentavam um processo de parcelamento para lotes menores e áreas próximas a estas também estavam sofrendo parcelamento urbano. Na figura $6.1 \mathrm{a}$ as setas mostram as feições presentes e as áreas ocupadas por vegetação natural.

Observar que a área da atual fazenda florestal que sofreu desmatamento em 72 passou a sofrer com processos erosivos, assim em 78 a cobertura havia sido reconstituída com objetivo de conter o processo que estava instalando-se. Em 78 verifica-se também a instalação de um porte de área, logo abaixo da SP-191.

Devido a população passa a ocupar esta área e ocasiona então uma maior concentração das águas pluviais, conduzindo o aumento considerável da área ocupada pelas feições (Figura 6.1c). Segundo informações de moradores locais, houve exploração de solo das encostas e de areia de calha de drenagem ao longo dos anos, isso pode ser evidenciado pela presença de empresas de extração de areia de rio até os dias nas proximidades das cabeceiras do Tucum. Este poderia também ser um causador do aumento destas feições.

\section{De 1978-1988}

Na foto de 1988 (Figura 6.2a) observa-se que a progressão das feições erosivas ocorreu em 3 pontos, a saber: o maior avanço se deu no ramo esquerdo da feição do Raia, associado ao aumento do escoamento superficial devido a ocupação urbana a montante, atingindo largura de aproximadamente $30 \mathrm{~m}$, seguido da porção central das feições da Florestal e a intensa progressão das ramificações da encosta esquerda do Dimas, provocada principalmente pelo direcionamento das águas pluviais pelas ruas do bairro São 
Dimas e das ramificações da encosta direita do Dimas e Tucum, não apresentando ligações diretas com o arruamento do Bairro recanto das águas.

Em 1988, observou-se que grandes mudanças nos tipos de uso e ocupação como:

- Boa parte da área encontrava-se agora ocupada por área urbana consolidada e em consolidação, onde a barreira a essa expansão eram as feições erosivas, que estavam intensamente ativas;

- A área de cobertura vegetal natural da fazenda florestal foi totalmente retirada em 1988 e substituída por pastagem. O reflexo deste novo tipo de uso e ocupação é o avanço intenso do processo erosivo nesta direção, causando a interdição total da estrada de terra São Pedro-Charqueada;

- A área da fazenda que apresentava uma feição erosiva do tipo voçoroca, passou a ser utilizada como disposição de resíduos sólidos;

- Fato marcante a se citar é o confronto entre a expansão urbana e o uso agrícola, principalmente na área ocupada por sítios e chácaras. Estas ultimas lutavam desde 1962 para não serem extintas;

- Ocorreu uma diminuição significativa da área ocupada por campo antrópico/pastagem.

Até esta data não havia registros de nenhuma técnica ou obra realizada na área com objetivo de controlar o processo erosivo. Provavelmente o aumento das vazões, provocado pela expansão urbana propiciou alterações nas características dinâmicas das feições já existentes. 
(a)

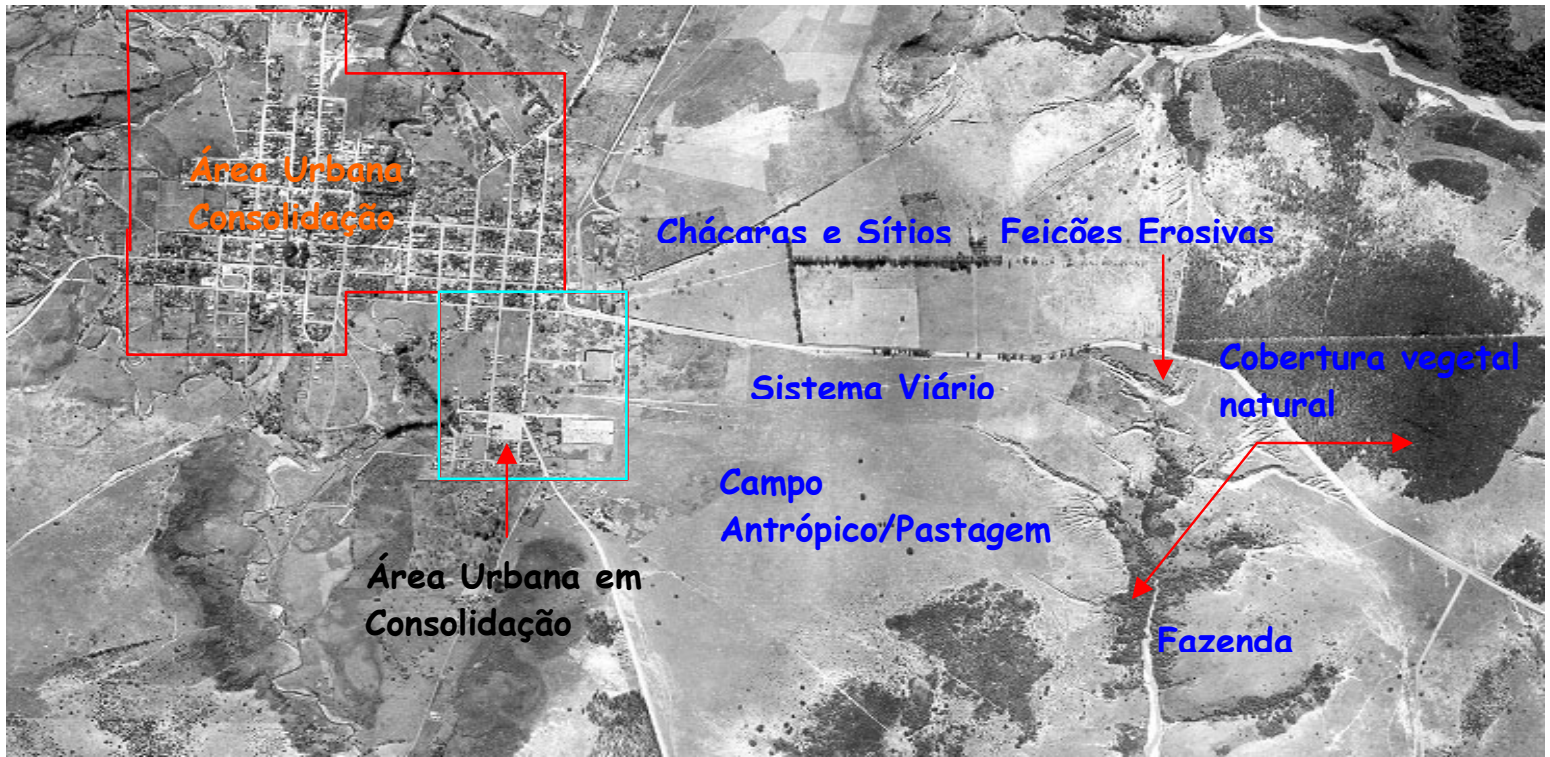

(b)
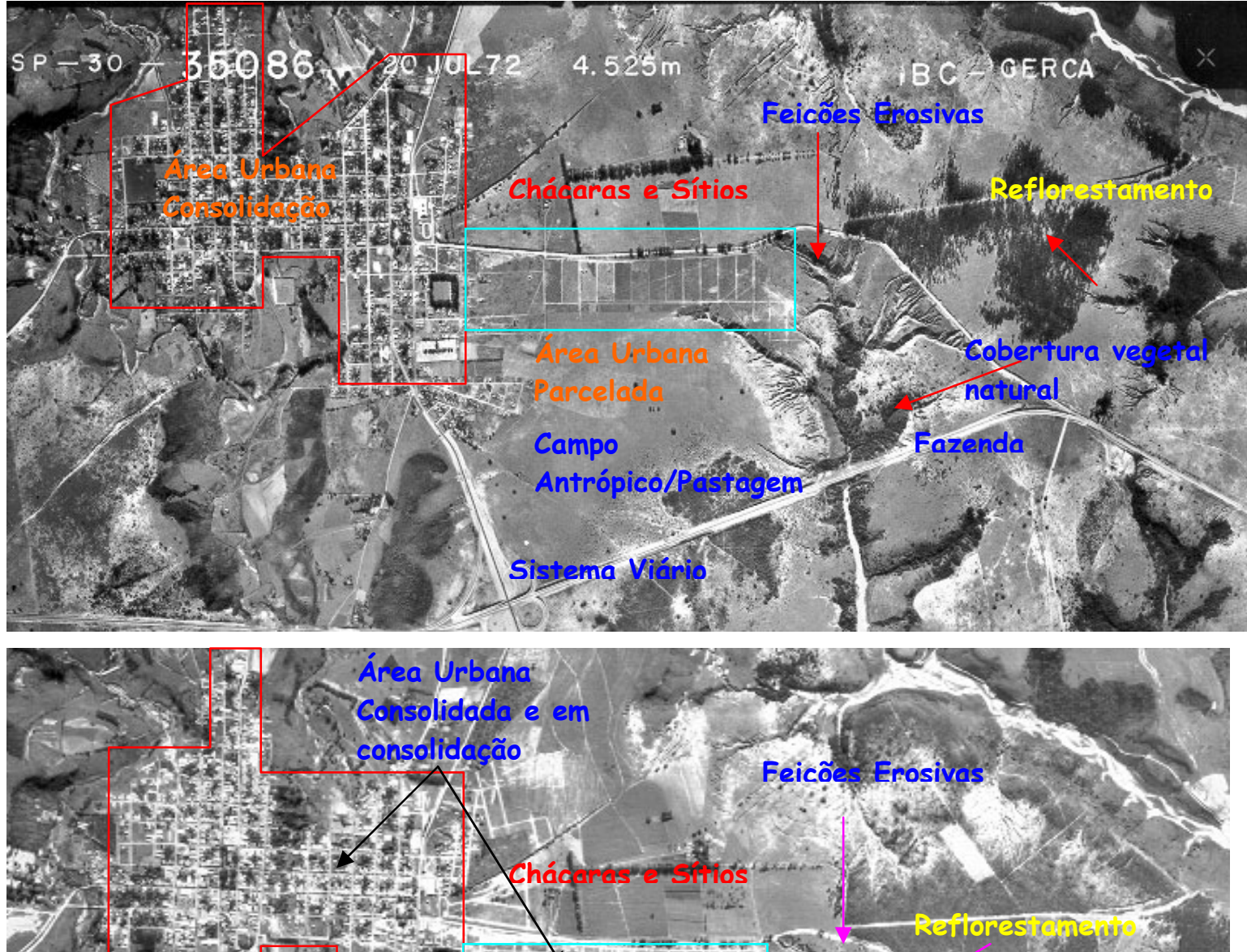

(c)

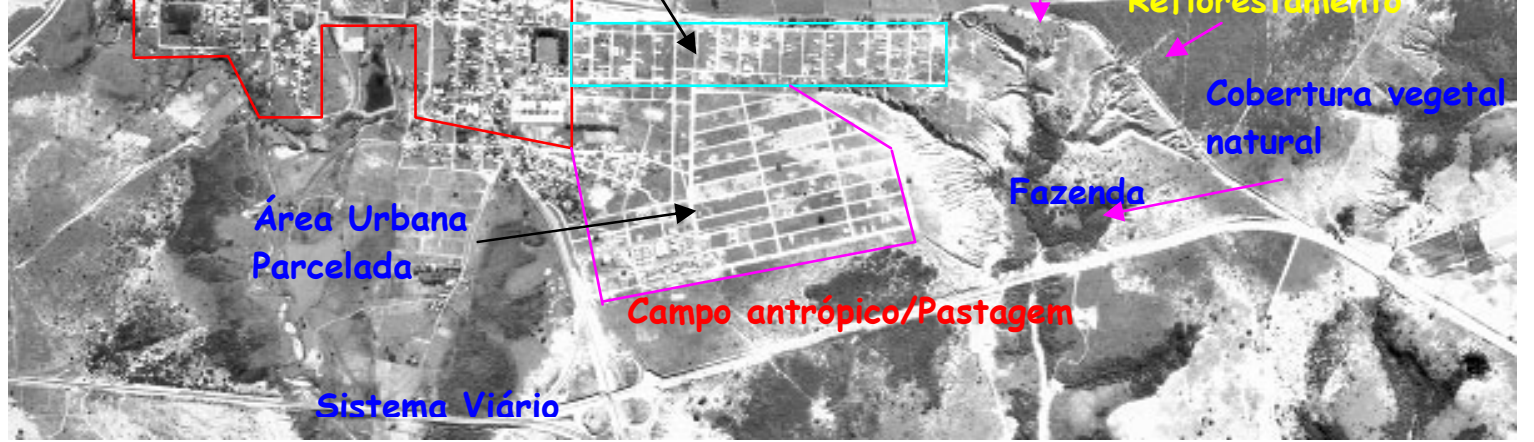

FIGURA 6.1- Fotografias aéreas da área de estudo em 1962 (a), 1972 (b) e 1978(c) mostrando os principais uso e ocupação do solo, e a evolução das feições erosivas. 


\section{De 1988-1995}

A partir da intensa progressão observada em 1988, e da continuidade do processo erosivo, no ano de 1990 existiam diversas ravinas associadas às 3 voçorocas préexistentes, além de surgências de água em diversos pontos e taludes bastante íngremes, de até 60m de altura segundo o IPT (1991) e Santoro (1991).

Diante deste quadro de alta criticidade devido à comprovação, na época, de que não havia qualquer obra de adução final das águas coletadas pela malha viária urbana, foram propostas então pelo IPT (1991) algumas obras como: sistemas de captação de águas de superfície e subterrâneas, diques marginais, terraceamento das encostas, barragens ao longo do talvegue e retaludamento. Salientou-se, na época, que a pavimentação do arruamento a montante deveria ser precedida de medidas corretivas e de controle do processo de erosão e associada à criteriosa coleta e adução das águas pluviais, além da criação, dentro do plano diretor do município, de áreas de proteção no entorno destas feições.

A partir de 1992 foram realizadas as primeiras obras de contenção, como aterramento das feições existentes (sulcos, ravinas e voçorocas), terraplanagem (abrandamento de taludes e aplanamento do terreno), terraceamento em nível (murundus), diques internos (construídos com material retrabalhado e espaçados em termos do perfil do canal), diques marginais, drenos de bambu (colocados com a finalidade de drenar águas subterrâneas, estes foram construídos a partir de feixes de bambu envoltos em lona de plástico) e retaludamento. Estas obras levaram em conta os fatores básicos para contenção da erosão, porém foram inadequadamente projetadas e executadas, e em muitos casos não concluídas, provocando a reativação do processo, como foi exposto pelo IPT em 1993 e observado nas fotografias aéreas.

A partir das recomendações feitas pelo IPT (1993) foram executadas novas obras em 1994, como pode ser observado na fotografia aérea de 1995 e em registros de documentos obtidos na prefeitura: Aterramento para preencher as feições presentes e a feição erosiva da florestal passou a ser aterrada desde de 1993 com resíduos sólidos provenientes da coleta seletiva, obras de microdrenagem, a área foi novamente terraplenada, retaludada e cordões de nível foram reconstruídos. 
(a)

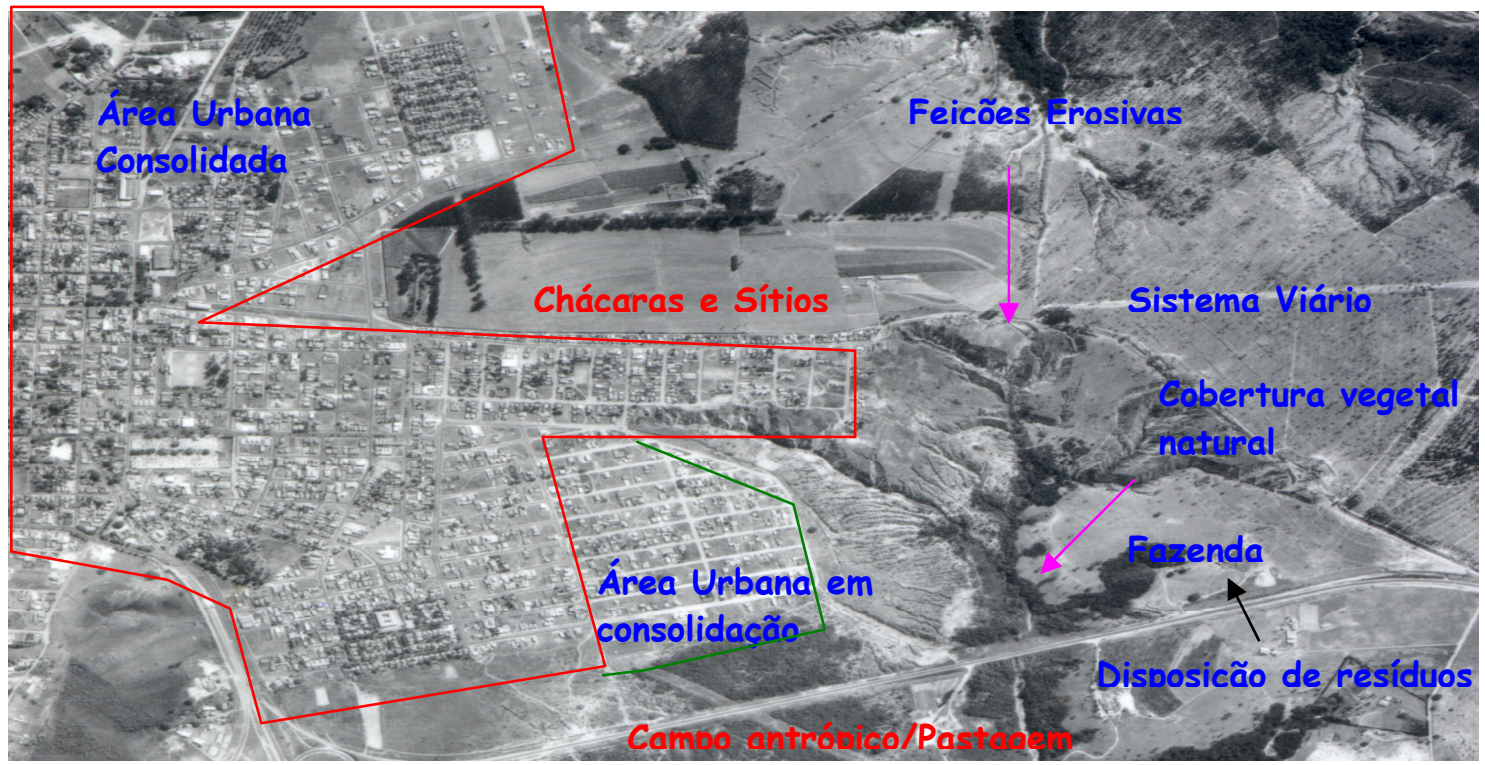

(b)

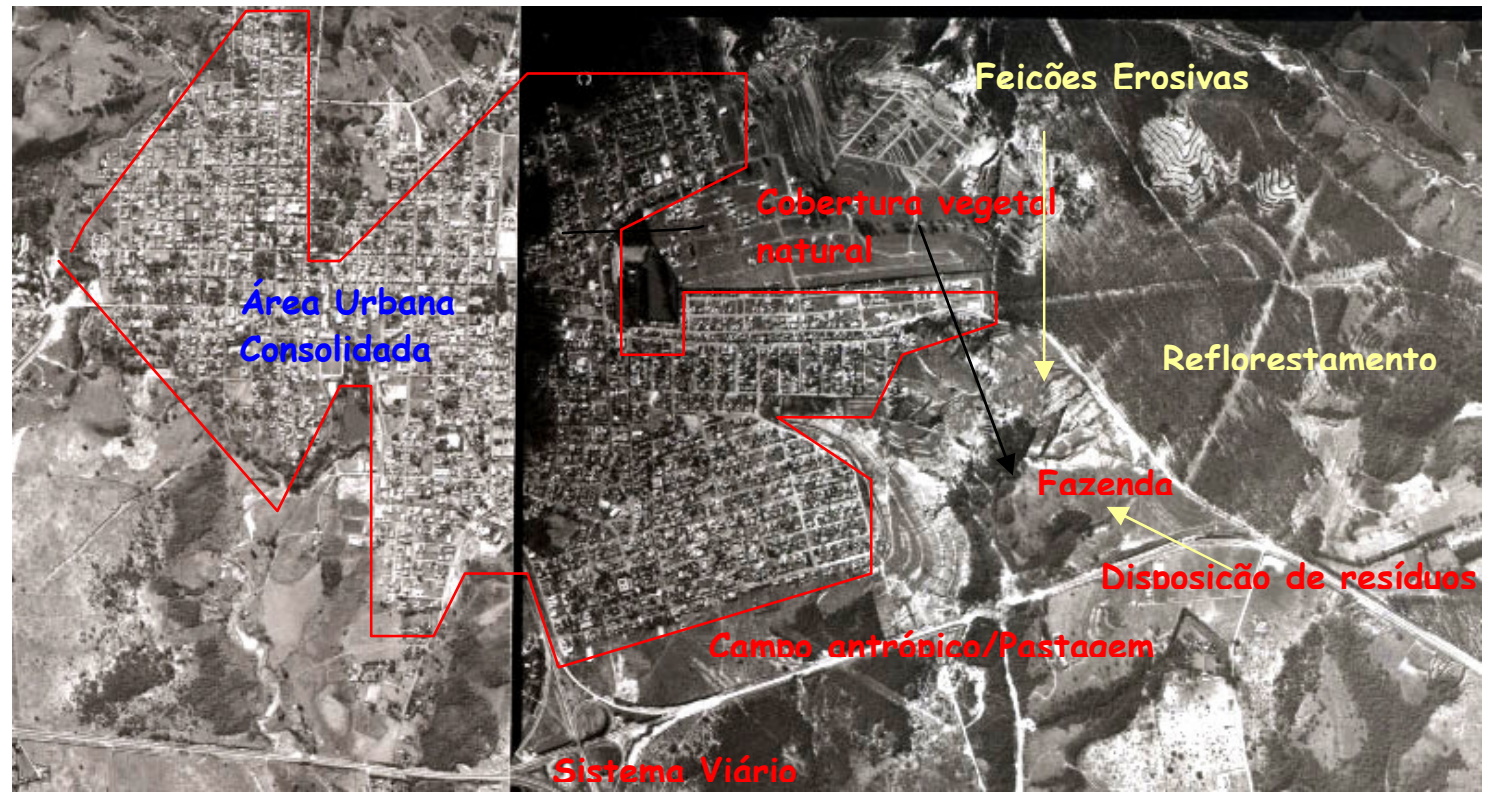

(c)

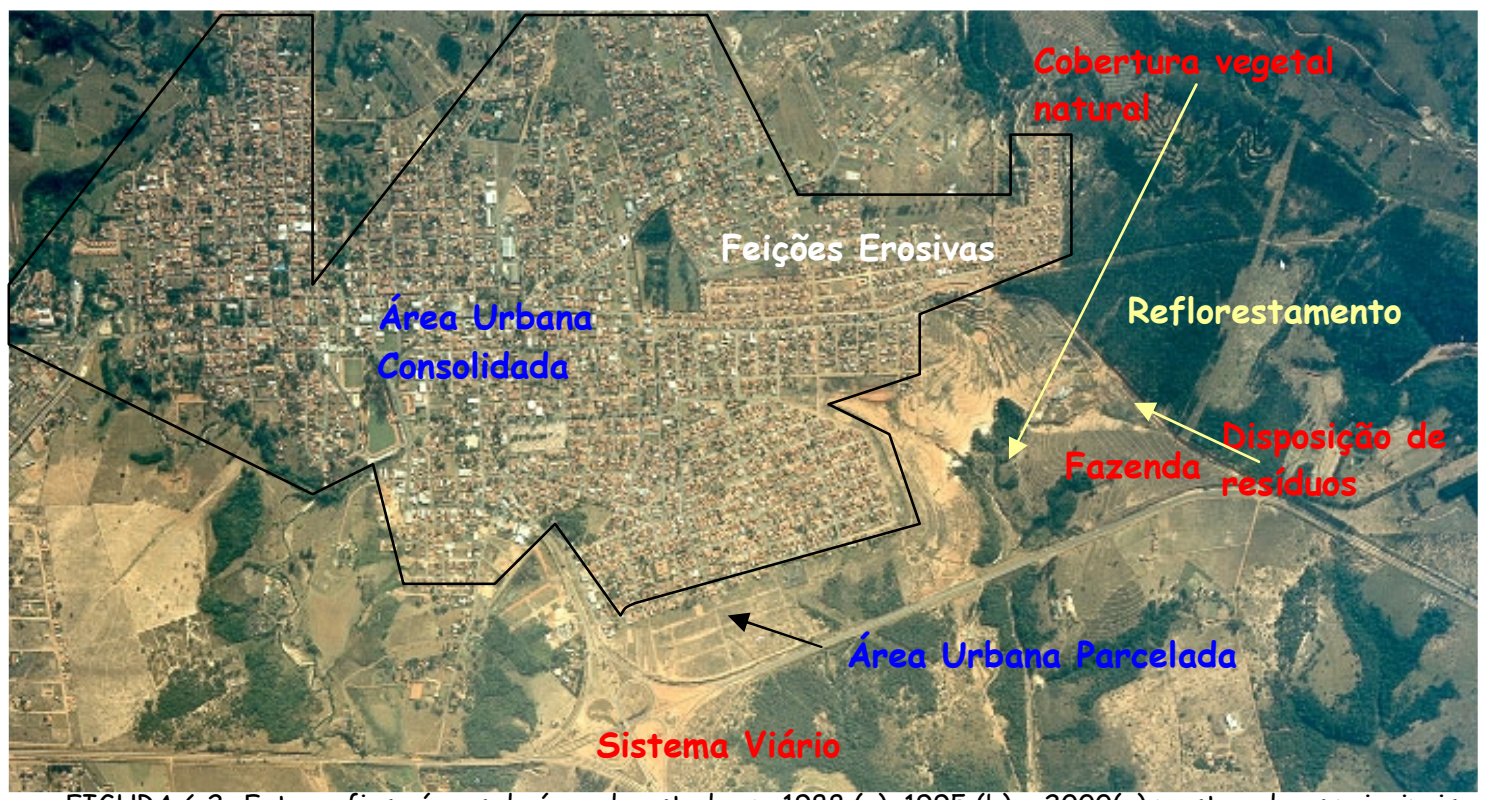

FIGURA 6.2- Fotografias aéreas da área de estudo em 1988 (a), 1995 (b) e 2000(c) mostrando os principais uso e ocupação do solo, e a evolução das feiç̃oes erosivas. 


\section{$3^{\circ}$ Estágio}

De 1995-2000

Este estágio caracteriza-se pelo efeito causado pelas obras de controle executadas na área durante o período anterior. Isto fica claro a partir das aerofotos de 1995 (Figura 6.2b), onde se constatou que os processos erosivos se intensificaram descontroladamente, expandindo as áreas afetadas anteriormente.

Estes processos são o reflexo das técnicas de controle executadas inadequadamente e da expansão urbana descontrolada destas áreas. Pode-se verificar a reativação das antigas linhas de drenagem, desenvolvimento de "piping", colapso de solos a montante, solapamento (ocasionou o alargamento das feições), escorregamentos das encostas das feições e ramificações ocasionadas pela evolução das incisões (causadas pela concentração do escoamento superficial dentro do talvegue).

A área apresenta também muitas modificações nas formas de uso e ocupação como:

- As doações de lotes pela prefeitura na bacia auxiliaram na consolidação da área urbana, mas isso não foi suficiente para controlar a demanda de habitação da população, que invadiu o topo da encosta do Raia, onde hoje fica a favela que leva seu nome; Vale lembrar que todos os canais receberam suas denominações através do uso e ocupação em que estão inseridos;

- A fazenda florestal se encontra totalmente coberta por reflorestamento de eucalipto e cordões de nível foram construídos para conter a evolução do processo erosivo nesta direção;

- As chácaras e sítios foram desestruturados, para dar lugar a lotes urbanos;

- A área da voçoroca da florestal passou a ser utilizada como área de deposição de resíduos sólidos, modificando consideravelmente sua forma de uso e ocupação.

Vale ressaltar ainda que a voçoroca da Florestal encontrava-se intensamente ativa nesta época comprometendo a estrada de terra São Pedro-Charqueada. As condições de degradação da área, associado a um evento chuvoso excepcional totalizando $651,1 \mathrm{~mm} \mathrm{em}$ Março de 1995, conduziram ao rompimento do aterro sobre o qual passava a rodovia SP191(São Pedro-Charqueada), causando a sua interdição por mais de um ano, além do colapso das obras de contenção construídas. Por esta razão estas obras tiveram que ser reconstruídas. 
A prefeitura municipal, por meio do decreto $n^{\circ} 2.955 / 95$ definiu a possibilidade de destruição dos barracos que ocupavam as encostas da voçoroca São Dimas por estarem em locais perigosos. Com vista a estes problemas, foram consideradas novas obras como: demarcação da rede de águas pluviais, novos cordões de nível e a área da voçoroca da florestal estava sendo aterrada com resíduos sólidos e transformada em lixão municipal, causando graves problemas ambientais (perigo de poluição das águas e solo), sociais, proliferação de doenças e catadores de lixo.

A situação da área em 2000 (Figura 6.2c) era de parcial controle tendo em vista as obras executadas. No entanto, estas obras não obtiveram a necessária manutenção, ocasionando o entupimento da rede de esgoto. Devido a este fato a rede de esgoto avariada foi conectada à tubulação de escoamento de águas superficiais, levando a ruptura $e$ vazamento de águas, provocando assim o solapamento da base de sustentação da drenagem de águas pluviais com o reinício do processo erosivo nestes locais. Estes tubos foram então retirados, ocasionando o aumento, de forma intensa, do processo erosivo, pela alta vazão dos despejos conjuntamente com as águas pluviais. No dia 24 dezembro de 2000, novo evento de chuva de $124 \mathrm{~mm} /$ dia, houve nova reativação descontrolada da voçoroca do bairro de São Dimas que provocou a retirada dos moradores das circunvizinhanças devido ao risco de destruição das residências próximas à feição e provocou o colapso das obras de controle. Logo a seguir foram então realizadas obras de terraplanagem em regime de emergência para desviar a rede de esgoto e águas pluviais do talvegue da voçoroca e foram consideradas novas obras como: construídas 2 barragens de terra ao longo do canal do Dimas, obras de microdrenagem, vala entre a rua Bandeirante e o primeiro cordão (margem direita do Dimas), obras de macrodenagem que englobaram a reconstrução de escadas hidráulicas e os cordões foram reconstruídos.

\section{De 2000-2003}

Atualmente, na área as feições erosivas encontram-se em atividade, com processos de escorregamento das paredes (Figura 6.3), condução e concentração de águas pluviais para o talvegue, presença de "piping", sulcos nas encostas cortando os "bolders" e presença do lençol freático aflorante. 


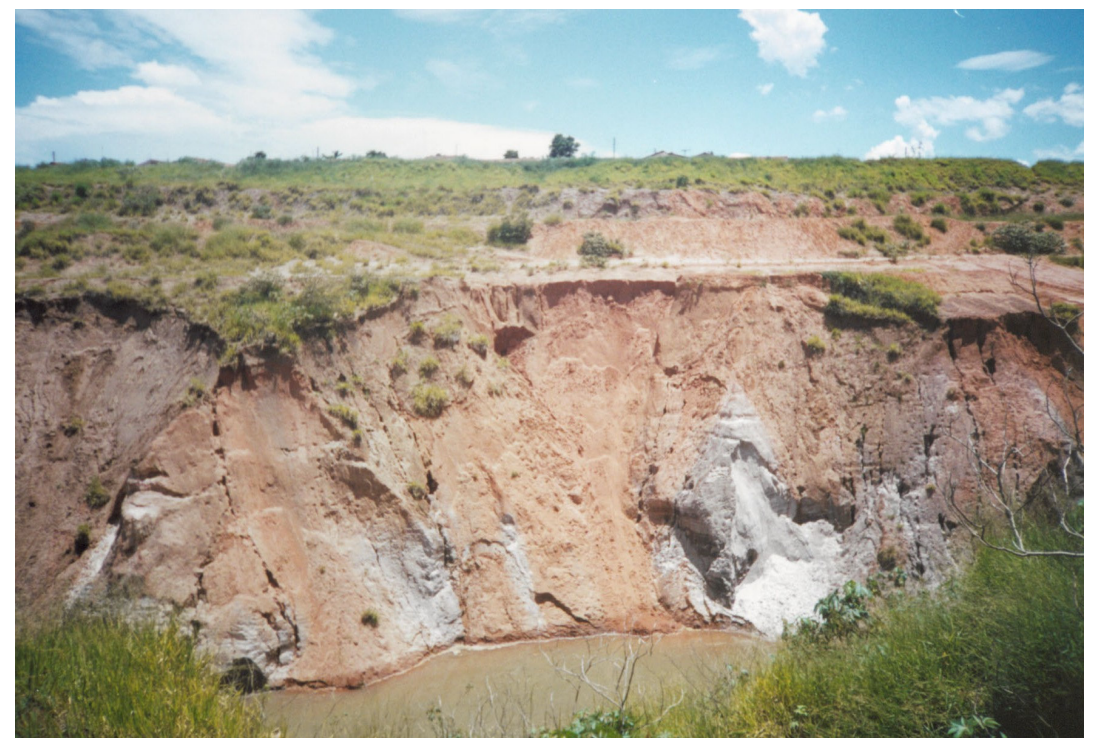

Figura 6.3- mostras a Voçoroca do São Dimas em intensa atividade em nov 2003, com escorregamento das encostas.

Em 2000 e 2003, verificou-se através da e trabalho de campo, que em termos de uso e ocupação a área urbana consolidada ocupa quase que totalmente a bacia. Mas existe ainda áreas parceladas de lotes onde em 2003, se solidificou o loteamento Santa Mônica.

Como medidas auxiliares de controle, o lixão foi fechado e desativado, única alteração em termos de uso e ocupação da bacia (Figura 6.4) e sua área foi aterrada com uma fina camada de solo da própria região. A estrada de terra São Pedro-Charqueada foi interditada com a finalidade de impedir que os catadores retornassem e uma nova área foi adquirida pela prefeitura do município para servir, a partir de então, como área de deposição de resíduos sólidos. A cabeceira da voçoroca do São Dimas (Figura 6.5) passou a ser uma área de deposição de resíduos de construção civil e restos de vegetação, caracterizando um novo problema. O loteamento nas margens da SP-191 até então interditado, foi liberado e hoje se encontra intensamente urbanizado. Para que este fosse liberado foi solicitado pela Secretaria de Meio Ambiente e Agricultura do Município de São Pedro, a construção de uma estação de tratamento de esgoto que desde julho/2003 está sendo construída, para fazer o tratamento do esgoto deste novo loteamento e de parte do bairro São Dimas. 

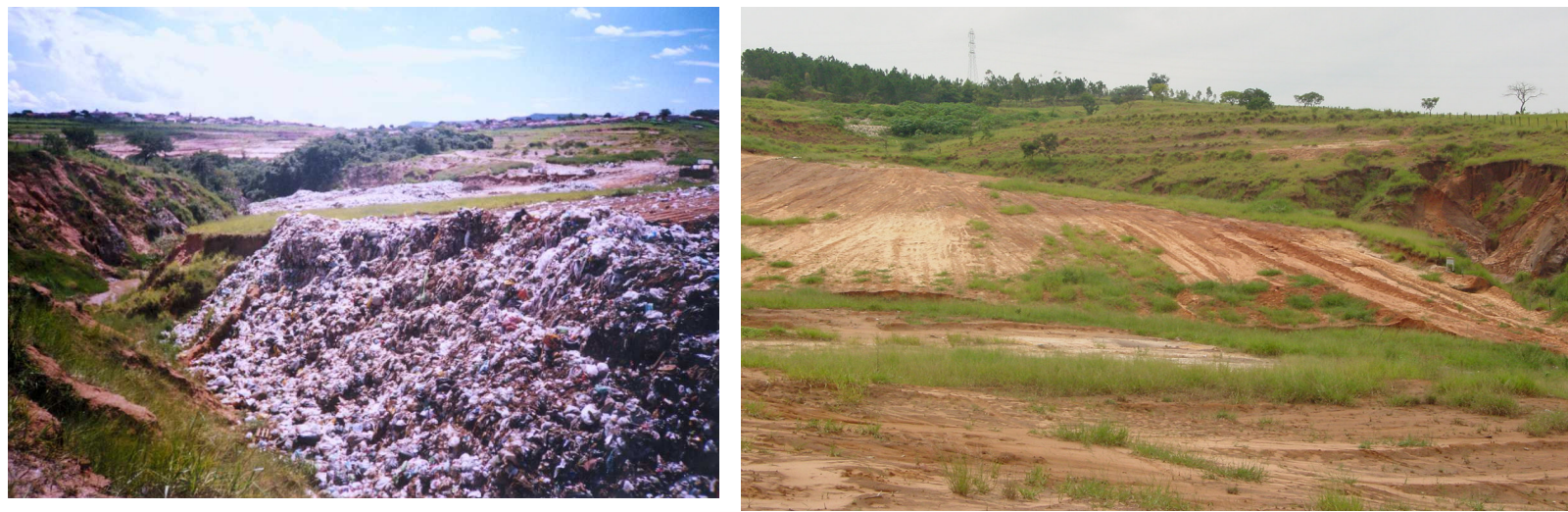

Figura 6.4- Voçoroca lixão em Jan/2003 antes de seu fechamento e depois de fechado e Aterrado.

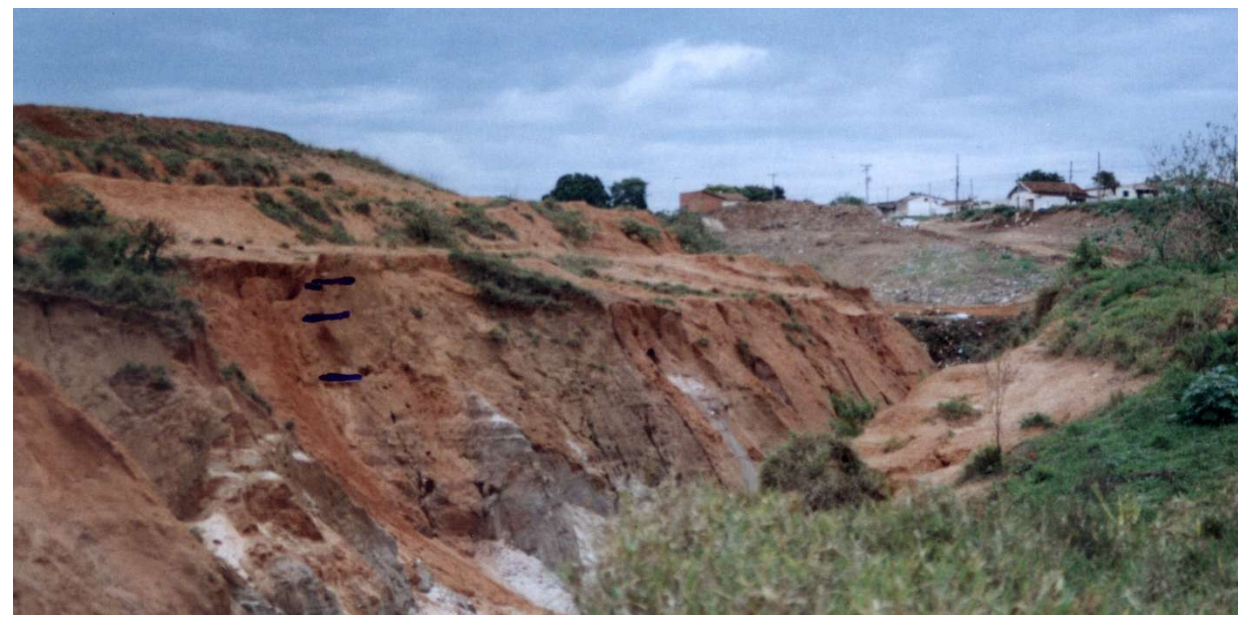

Figura 6.5- o inicio do canal do São Dimas, passou a ser utilizada como área de deposição de resíduos de construção civil e restos vegetais.

A voçoroca do Raia (Figura 6.6), que fica entre o bairro de São Dimas e o antigo lixão, até então estabilizada, em janeiro/2003 apresentou os primeiros vestígios de reativação pela presença de escorregamentos das paredes e pelo rompimento dos tubos de drenagem de águas pluviais que passam pela antiga feição, ocasionando solapamento do solo da base e formando uma nova erosão. Em setembro de 2003 foram executadas obras para recuperar o sistema de drenagem, durante as obras foi aberto um caminho para entrada das máquinas que atualmente pode ser considerado um ponto de risco de reativação da feição. 
(A)
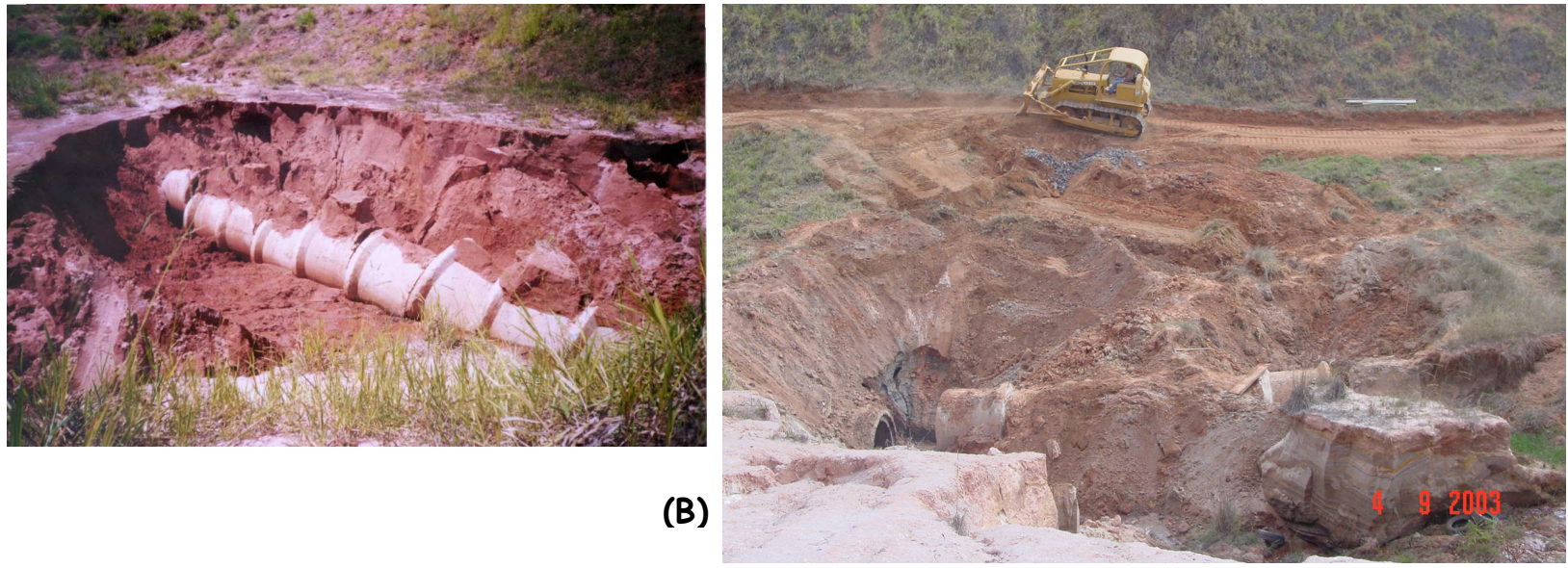

Figura 6.6- reativação da voçoroca do Raia devido rompimento do sistema de captação de águas pluviais em Jan/03 (A), esta foi recuperado em Outubro/03 (B).

A voçoroca do Recanto das Águas encontrava-se parcialmente controlada devido ao desvio das águas pluviais e da rede de esgoto (Figura 6.7), onde se pode verificar a retomada da vegetação no talvegue. No entando em outubro/2003 esta feição foi totalmente aterrada com material retrabalhado de suas encosta e feito uma caixa para condução das águas, mas o fato é que esta se encontra numa posição mais elevada, causando o acumulo de água e trincamento do aterro. Todas as obras de controle até os dias atuais permanecem sendo reparadas (Figura 6.8), mas nenhuma outra técnica foi aplicada.
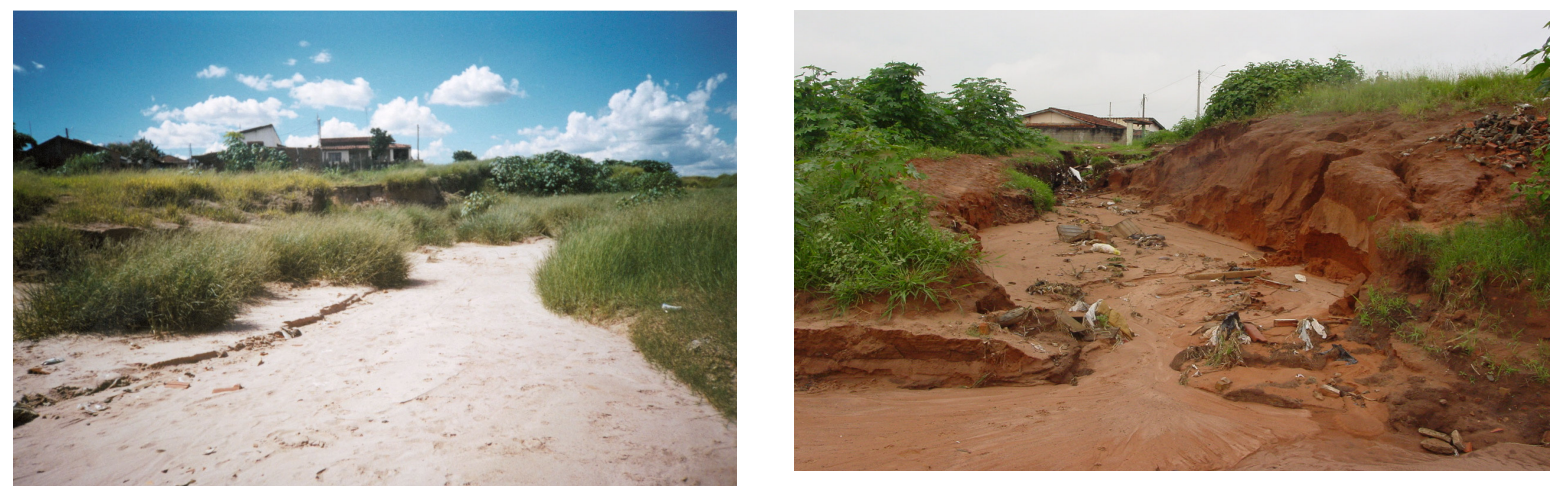

Figura 6.7- voçoroca do Recanto da Águas antes do seu aterramento em Out de 2003 (A) e depois de suas reativação em Março de 2000. 


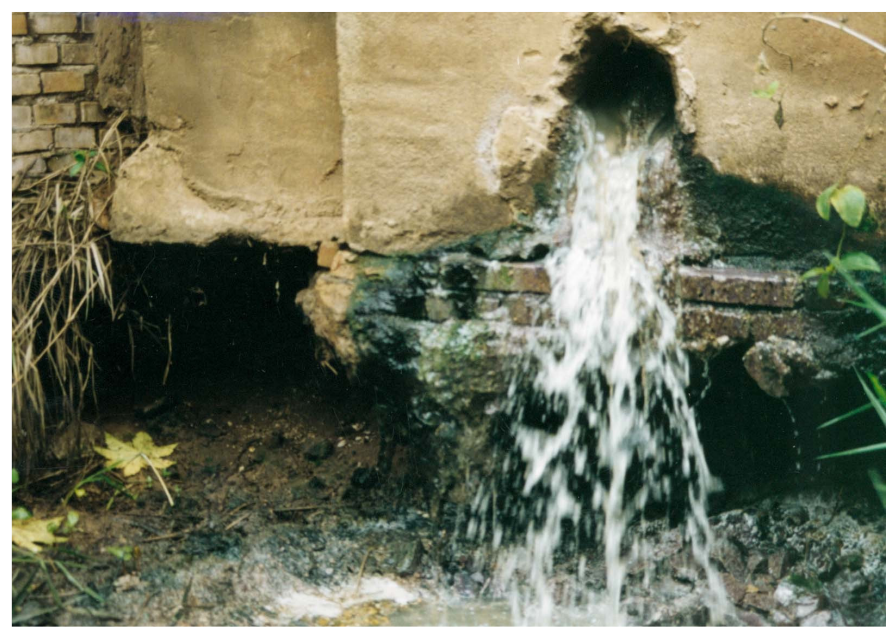

Figura 6.8- Colapso das obras de controle de microdrenagem, que depois são reconstruídas. 


\section{CONCLUSÕES E RECOMENDAÇÕES}

A sistemática de estudo apresentou-se eficiente na concepção de um entendimento global da evolução das feições erosivas na área, que foi escolhida devido a incidência histórica de problemas ambientais ocasionados pelos processos erosivos e da aplicação de técnicas de controle e reabilitação para solucionar estes problemas. Possibilitando assim um entendimento claro das causas da ocorrência destas feições e sua relação como meio.

O levantamento bibliográfico executado nesta pesquisa visou buscar um embasamento teórico e abrangente sobre: os aspectos conceituais sobre erosão e os problemas ambientais decorrentes; os tipos e mecanismos dos processos erosivos; mapeamento geotécnico e geoprocessamento voltado para erosão; os tipos de feições erosivas; os principais tipos e medidas de técnicas de controle e recuperação utilizadas no Brasil e internacionalmente para solucionar ou amenizar as áreas erodidas.

Os ensaios laboratoriais de caracterização geotécnica básica, compactação, cisalhamento direto, erodibilidade e CTC realizados neste trabalho e de permeabilidade realizada em situ, foram importantes para caracterização dos diversos materiais geológicos e identificar o material $R+7$, que se mostrou importante na deflagração dos processos erosivos.

Já os documentos cartográficos produzidos: mapa de documentação, mapa de feições erosivas (1962, 1972, 1978, 1988, 1995 e 2002), mapa de materiais inconsolidados, mapa de landforms, mapa de microbacias, mapa das obras de controle de feições erosivas, e carta de declividade serviram de suporte para as análises dos processos erosivos e da eficiência das técnicas de controle e recuperação utilizadas na área de estudo.

O cadastramento das feições foi fundamental para o melhor conhecimento da distribuição espacial e temporal das erosões, desta forma pôde-se delimitar as áreas de maior concentração na cabeceira e a forma com que elas evoluíram. O levantamento das áreas de controle e recuperadas foi importante para a melhor compreensão do processo 
De onde ocorreu a propagação do processo e reativação destas áreas, tornando possível à análise da eficiência das medidas adotadas.

Os principais condicionantes do processo erosivo foram definidos como:

- A diversidade de materiais nos perfis de alteração, apesar do mesmo substrato rochoso, em diferentes localizações, expõem a rocha (arenitos da Formação Pirambóia) em diferentes condições de alteração. Com base nos ensaios realizados e na textura arenosa dos materiais inconsolidados, tanto residuais como os retrabalhados são susceptíveis a erosão;

- As características dos landforms com diversas combinações de encostas, a forma coletora da bacia;

- Formas de uso da parte montante da bacia.

O principal deflagador é o escoamento superficial gerado pelas chuvas, principalmente, na parte da bacia urbanizada. A taxa do escoamento superficial tem aumentado com o avanço da urbanização e do posicionamento das ruas no sentido da maior declividade de cada encosta.

A ocupação urbana avançou predominantemente na porção montante desde o divisor de águas. Atualmente, aproximadamente $50 \%$ da bacia esta urbanizada, portanto, com uma geração de escoamento superficial muito elevado, condicionando um grande volume de água aumentando a vazão de pico, diminuindo assim os tempos de concentração e de pico.

As três maiores e principais feições foram identificadas desde de 1962, o que significa que os problemas causados pela erosão já perduram por mais de 40 anos. Pode-se notar ainda um aumento progressivo do número de feições, diminuição do número de concentrações de sulcos e aumento do número de feições do tipo ravina e voçoroca a partir de feições de menor porte ao longo dos anos até 1988. A partir de 1992 com início da implantação de técnicas de controle e recuperação, percebe-se que houve uma diminuição progressiva do número de todos os tipos de feições e no número total. Refletindo então que estas técnicas mostram um certo grau de eficiência em alguns locais. A pesar da área ter sofrido com dois eventos mais intensos de deflagração em 1995 e 2000.

Portanto em função do dimensionamento, posicionamento e implantação das obras de drenagem de águas pluviais, cordão de nível, aterramento entre as outras técnicas descritas nesta pesquisa, pode-se considerá-las inadequadas já em relação aos tipos, podese considerar que a grande maioria se enquadra como adequadas. 
Em algumas partes é possível observar que as medidas foram eficientes, como na encosta direita do canal do Dimas/Tucum, onde a vegetação esta desenvolvendo. Ao contrario a tentativa de instalação de uma estação de tratamento em julho de 2003 veio alterar a estabilidade que vinha acontecendo.

A implantação da técnica de controle do tipo reflorestamento com eucalipto na área da fazenda florestal em diversos momentos no estudo do uso e ocupação, que posteriormente foi associada com cordões de nível, mostrou-se eficiente para o combate da erosão. Hoje o manejo adequado desta área recuperada, possibilita a sustentabilidade do uso comercial da extração da madeira e estabilidade dos processos erosivos.

Nas encostas da favela do Raia, não há instalação de processo erosivo nos últimos anos e na área da florestal (lixão) que foi interditada e aterrada, apresenta os primeiros indícios de reativação após as chuvas de 2004.

A atual situação em relação à prevenção e controle da erosão na área de estudo é variável dependendo do local avaliado variando de eficiente a ineficiente. A prefeitura municipal de São Pedro não possui técnicos com conhecimento em controle de erosão, como também, não existe plano de emergência no caso da deflagração de novo processo ou avanço repentino de um processo instalado e, ainda, não possuem condições financeiras de realizar obras de controle e contenção das erosões que se encontram em atividade. Atuando apenas no processo de reconstrução das obras de controle já executadas.

Até o momento foram gastos $R \$ 800.963 .78$ em obras de drenagem de águas pluviais e recuperação de aterros registradas em dois períodos (1994 e 1996). Mas considerando que muitas outras obras foram executadas, mais não apresentam registro de custos. Estima-se este montante poderia ser bem superior a 1 milhão de reais, desde de 1992.

Com base no estudo realizado propõe-se as seguintes medidas para minimizar os problemas de erosão na área:

1- Manter como áreas de preservação permanente (faixa mínima de $30 \mathrm{~m}$ a partir das margens fluviais, dependendo do canal), incluindo cabeceiras de drenagem e nascentes de água ( $50 \mathrm{~m}$ a partir da cabeceira ou nascente), podendo se estender conforme os processos atuantes, recomposição desta mata ciliar e torná-las áreas de preservação ou parques: 
2- com urgência, tentar evitar os problemas encosta direita do Tucum, com a instalação da estação de tratamento, que por falta de conclusão das obras antes do período de chuvas de 2004, acabaram por expor material com alta erodibilidade, provocando reativação do processo. No futuro propõe se evitar obras de longa duração, principalmente nos períodos chuvosos, diminuindo assim as perdas econômicas e reativação/instalação de novas feições;

3- conter e projetar sistemas para drenar as águas da porção a montante da bacia, principalmente na bacia do Dimas;

4- propor medidas de minimização de energia na porção onde os canais do Dimas, Raia e da Florestal convergem;

5- re-analisar a distribuição dos cordões de nível, buscando evitar os pontos de depressão onde as águas acumulam;

6-evitar movimento de terra principalmente com a destruição dos cordões de nível;

7- evitar o escoamento superficial em direção as paredes do canal e do Dimas, evitando assim o desmoronamento e o surgimento de canais em bifurcação;

8- instalação de um pluviágrafo de controle, monitoramento e alerta, para defesa civil e uma equipe de acompanhamento das obras, quando da ocorrência de chuvas com intensidades calculadas para duração superiores a $75 \%$ do tc da bacia;

9- Na abertura e reaterro de valas para colocação de guias e sarjetas e tubulações de drenagem, assegurar perfeita compactação e proteção superficial do solo;

10- Em caso de cortes e aterros, prever a revegetação imediata para evitar reativação ou nova incidência de processos erosios;

11- substituir tubulações para diâmetro maior:

12- relocar bocas de lobo, galerias e etc.

Tendo em vista o cenário descrito pode-se concluir que há necessidade de uma avaliação das formas de controle a serem adotadas futuramente, mostrando que parcela da área será controlada e/ou recuperadas pela mesma. Assim como também uma avaliação do impacto ambiental negativo provocado por estas obras ao longo dos anos e os custos associados.

Estes fatores evidenciam a importância do entendimento da evolução dos processos erosivos em áreas urbanas como uma ferramenta útil no planejamento territorial, pelo fato de direcionar as novas obras a serem executada, sua forma de execução e manutenção. Portanto, auxiliando no desenvolvimento de uma gestão territorial mais equilibrada. 


\section{REFERÊNCIAS BIBLIOGRÁFICAS}

ASSOCIAÇÃO BRASILEIRA DE NORMAS TÉCNICAS -ABNT (1989). Norma:

Degradação do Solo: Terminologia (NBR 10 703).

ALBRECHET, K.J (1998)- Avaliação geológica-geotécnica de terrenos sujeitos a problemas cárticos. Dissertação de Mestrado. EESC/USP. São Carlos -SP. 210p.

ALBUqUERQUE, A. W., LOMBARDI NETO, F., CATANEO, A. \& SRINIVASAN, V. S. (1998) - Parâmetros erosividade da chuva e da enxurrada correlacionados com as perdas de solo de um solo Bruno não-cálcico vértico em Sumé (PB). In: Revista Brasileira de Ciência do Solo. Viçosa. No 22. p 743-749.

ALMEIDA, M.C.J.; FREITAS, C.G.L. (1996). Uso do solo urbano: suas relações com o meio físico e problemas decorrentes. IN: SIMPÓSIO BRASILEIRO DE CARTOGRAFIA GEOTÉCNICA, 2./ENCONTRO REGIONAL DE GEOTECNIA E MEIO AMBIENTE, 1996, São Carlos. Anais... São Paulo: ABGE. p.195-200.

ALMEIDA FILHO, G. S. (1998) - Prevenção de erosão em áreas urbanas. In: VI Simpósio Nacional de Controle de Erosão. ABGE. Presidente Prudente-SP. Anais... (CD ROOM).

ALCÂNTARA, M.A.T (1997)- Estudos da erodibilidade de alguns solos do estado de São Paulo. Tese de Mestrado; EESC/USP, 129p.

AKABASSI, L. (1999) - Estudo teórico - experimental do processo erosivo em áreas de encosta. Tese de Doutorado. EESC/USP. São Carlos - SP.

ALMOROX, J., DE ANTONIO, R., SAA, A., DÍAZ, M. C. \& GASCÓ, J. M. (1994) Metodos de Estimación de la Erosion Hídrica. Editorial Agrícola Española. 152p. Madrid España.

ALVES, L. M. (1993) - Sistemas de Informações Geográficas como Instrumentos para o Planejamento de Uso da Terra, em Bacias Hidrográficas. Viçosa: UFV. 112p 
ARAÚJO, D. E. (1995) - Considerações sobre as obras de controle de erosão do solo urbano no estado de São Paulo. In: $5^{\circ}$ Simpósio Nacional de Controle de Erosão. ABGE/UNESP. Bauru-SP. V2. p 63-68.

ARAÚJO, P. R. ,TUCCI, C.E.M. \& GOLDENFUM, J. A .- Avaliação da eficiência dos pavimentos permeáveis na redução de escoamento superficial. Instituto de Pesquisas Hidráulicas da UFRGS- Porto Alegre-RS.

BRICE, J.C.(1966)- Erosion and depositon in the loess-mantled Great Plains, Medicine Creek drainage basin, Nebrask. U.S. Geological Survey Professional Paper 352-H,p.255339.

BRYAN, R.B. (2000). Soil erodibility and proceses of water erosion on hillslope. Geomorphology, Amsterdam, v.3, n. ,p.385-415, mês.

BACHION, M. L. (1997) - Mapeamento Geotécnico da Área Urbana e de Expansão da Região Metropolitana de Campinas, Escala 1: 25000. Dissertação de Mestrado. EESC/USP. São Carlos -SP.

BITAR, O.У. \& BRAGA, T. O. (1995)- O meio físico na recuperação de áreas degradadas. São Paulo, curso de geologia Aplicada ao Meio Ambiente. IPT/ABGE.

BERTONI, J. \& LOMBARDI NETO, F. (1999) - Conservação do Solo. 4a Edição. 355p. Editora Ícone. São Paulo - SP.

BIGARELLA, J. J. \& MAZUCHOWSKI, J. Z. (1985) - Visão Integrada da Problemática da Erosão. In: ABGE/ADEA, Maringá. 332p.

BITAR, O.У., \& ORTEGA, R. D. Gestão Ambiental In: ASSOCIAÇÃO BRASILEIRA DE GEOLOGIA DE ENGENHARIA (ABGE) - Geologia de Engenharia. Edição histórica. São Paulo.1998. Cap.32, p.499-508.

GALERANI, $C$. et al. Controle de erosão urbana. In: TUCCi,C.E.M., PORTO, R.L.L., BARROS,M.T.Drenagem Urbana. Porto Alegre: Editora da Universidade Federal do Rio Grande do Sul, 1995.Cap.8, p.349-385.

GUERRA, A. J. T. \& CUNHA, S. B. (1995) - Geomorfologia: Uma Atualização de Bases e Conceitos. $2^{a}$-Edição.Editora Bertrand Brasil. Rio de Janeiro - RJ.

GUERRA, A. J. T. \& CUNHA, S. B. (2001) - Impactos Ambientais Urbanos. Editora Bertrand Brasil. Rio de Janeiro - RJ.

BIDONE, F. \& TUCCI, C. E. M (1995)- Microdrenagem In: TUCCi,C.E.M., PORTO, R.L.L., BARROS,M.T.Drenagem Urbana. Porto Alegre: Editora da Universidade Federal do Rio Grande do Sul, 1995.Cap.3, p.77-1065. 
CAMPOS, S. P.: SIMÕES, L.B.: RIBEIRO, F. L. \& ZIMBAK,C. R. L. (1998)Krigagem ordinária na avaliação da sustibilidade de solos a erosão. In: VI Simpósio Nacional de Controle de Erosão. ABGE. Presidente Prudente-SP. Anais... (CD ROOM).

CANIL, K., IWASA, O. Y., SILVA, W. S. \& ALMEIDA, L. E. G. (1995)-Mapa de Feições Erosivas Lineares do estado de São Paulo: Uma Análise Qualitativa e Quantitativa. In: $5^{\circ}$ Simpósio Nacional de Controle de Erosão. ABGE/UNES. Bauru-SP. V5. p 249-251.

CAVAGUTI, N. - Uso do lixo no controle de erosão. In: $5^{\circ}$ Simpósio Nacional de Controle de Erosão. ABGE/UNESP. Bauru-SP. V2. p 97-99.

CANIL, K. (2001) - Proposta metodológica para elaboração de cartas geotécnicas voltadas à prevenção de erosão. In: VII Simpósio Nacional de Controle de Erosão. ABGE. GoiâniaGO. Anais... (CD ROOM).

CARVALHO, J. \& MORTARI, D. (1995) - Formação e contenção de voçorocas no Distrito Federal. In: $5^{\circ}$ Simpósio Nacional de Controle de Erosão. ABGE/UNES. Bauru-SP. V2. $\mathrm{p}$ 73-76.

CARVALHO, J. C., LIMA, M. C \& MORTARI, D. (2001) - Considerações sobre prevenção e controle de voçorocas. In: VII Simpósio Nacional de Controle de Erosão. ABGE. Goiânia-GO. Anais... (CD-ROOM).

CERRI, L. E. S., (1993)-Riscos geológicos associados a escorregamentos: Uma proposta para a prevenção de acidentes. Rio Claro. (Tese de Doutorado IGCE/Unesp - Rio Claro). p. 197.

CERRI, L. E. S., SILVA, J. A. F. \& SANTOS, P. H. P. (1997) - Erosão do Solo: Aspectos Conceituais. Revista Universidade Guarulhos. Geociências, II (6): p 92-98.

CERRI, C. E. P. (1999) - Mapeamento das Áreas de Risco de Erosão dos Solos da Bacia do rio Piracicaba, utilizando Geoprocessamento. Dissertação de Mestrado. ESALQ. Piracicaba -SP.

CHAVES, H. M. L. (1995) - Aplicação de Modelos na Previsão da Erosão. In: $5^{\circ}$ Simpósio Nacional de Controle de Erosão. ABGE/UNESP. Bauru-SP. V2. p 49-54.

CHISTOFOLETTI, A. (1999) -Modelagem de sitemas ambientais. São Paulo: Editora Edgard Blucher LTDA. P. 236.

COELHO NETO, A.. L. (1998) - Diagnóstico de erosão para o planejamento regional: subsídios metodológicos sob enfoque geo-hidroecológico. In: VI Simpósio Nacional de Controle de Erosão. ABGE. Presidente Prudente-SP. Anais... (CD ROOM). 
COELHO, A.T. \& GALVÃO, T. C. B. (1998) - Controle de erosão em taludes de disposição de rejeito siderúrgicos com tapete biodegradávél. In: VI Simpósio Nacional de Controle de Erosão. ABGE. Presidente Prudente-SP. Anais... (CD ROOM).

CONCINI,W. (1998)-Surgimento de voçorocas em áreas de solo colaosível. In. VI Simpósio Nacional de Controle de Erosão. ABGE. Presidente Prudente-SP. Anais... (CD ROOM).

CONDEC - Conselho de Defesa Civil São Pedro (2000)- Erosão do Bairro São Dimas histórico de evento de alto risco. Município de São Pedro, SP. São Paulo. (CONDEC Relatório, 003/01).

CRUZ, R. \& SILVA, M (1995) - Critério nas estruturas de contenção de processos erosivos. In: $5^{\circ}$ Simpósio Nacional de Controle de Erosão. ABGE/UNESP. Bauru-SP. V2. p 69-71.

DAEE (1980) - A atuação do departamento de águas e energia elétrica no combate à erosão urbana do Estado de São Paulo. Diretoria de Obras do Departamento de Águas e Energia Elétrica. In: Simpósio sobre o Controle de Erosão. ABGE. Curitiba-PR. p 05-34.

DAEE. (1990). Controle de erosão: bases conceituais e técnicas, diretrizes para planejamento urbano e regional; orientação para o controle de boçorocas urbanas. 2. ed. São Paulo: DAEE/IPT. 92 p.

DASGUPTA, P. (1994) - Optimal versus sustainable delevelopment. In valuing the enviroment (SERAGELDIN, I \& STTEER, A, Eds.).Washigton, The World Bank, p.35-46.

D'AGOSTINI, L. R. (1999) - Erosão: o Problema mais que o Processo. Editora da UFSC. 131p. Florianópolis - SC.

DALLA ROSA, A. (1981) - Práticas mecânicas e culturais na recuperação de características físicas de solos degradados pelo cultivo no solo Santo Ângelo (Latossolos roxo distrófico). Dissertação de Mestrado. Faculdade de Agronomia/UFRGS. Porto Alegre - RS.

ELLERT, N. (1980)- Geologia Ambiental da área de São Pedro/SP- vetor de águas subterrâneas. Tese de Doutorado- Instituto de Geociências da Universidade de São Paulo. $67 p$.

FRANCICANI, E. M. (1995)- Influência da estrutura e tect6onica no desenvolvimento de boçorocas na Região de São Pedro-SP: proposta de reabilitação e aspectos JurídicosInstitucionais correlatos- Dissertação de Mestrado- UNESP- Rio Claro. 124p. 
FIORI, O. C. \& SOARES, P. C. (1976) - Aspectos Evolutivos das Voçorocas. Notícias Geomorfológicas. Campinas. V16. № 32. p 114-124.

FIORE- OKA, C.(1980)- Contribuição ao estudo das formações superficiais das quadriculas de Piracicaba e São Pedro- Dissertação de Mestrado- UNESP- Rio Claro. 121p.

FRENDRICH, R. (1997 a)- Erosão Urbana. In: FREDRICH, R., OBLADEN, N. L., AISSE, M. M. \& GARCIAS, C. M. -Drenagem e Controle da Erosão Urbana. Curitiba: Editora Ibrasa/Champagnat, Cap.1, p.17-49.

FRENDRICH, R. (1997b)- Hidrologia Aplicada. In: FREDRICH, R., OBLADEN, N. L., AISSE, M. M. \& GARCIAS, C. M. -Drenagem e Controle da Erosão Urbana. Curitiba: Editora Ibrasa/Champagnat, Cap.3, p.125-194.

FELIPE, R. S (1998)- A Erodibilidade da formação Guabirotiba. Minerais do Paraná S/ACuritiba: MINEROPAR

FILHO,J.F.M: COSTA,J.A; CRUZ, A.M.P:MAIA, R.M.B- Caracterização de três leguminosas para utilização como plantas de cobertura do solo e controle de perdas por erosão. In: VII Simpósio Nacional de Controle de Erosão. ABGE. Goiânia-GO. Anais... (CD ROOM).

FIORI, O. C. \& SOARES, P. C. (1976) - Aspectos Evolutivos das Voçorocas. Notícias Geomorfológicas. Campinas. V16. № 32. p 114-124.

FONTES, S. B. (1998) - Mapeamento Geológico com Ênfase em Erosão. Seminários Gerais em Geotecnia - SGS- 833, EESC/USP. São Carlos - SP.

FREIRE, O., GODOY, M. C. T. F. \& CARVALHO, W. A. (1992)-Erodibilidade de alguns solos do oeste do Estado de São Paulo. Revista de Geografia. São Paulo. V11. p 7787.

FRANCHI (2000)- Aplicação de turfa na recuperação de solos degradados pela mineração de areia. Disertação de Mestrado. Escola Politécnica de São Paulo/USP. São Paulo - SP.

GAGG, L. \& GOMES, C. (1998) - Controle de erosão com emprego de módulos téxteis, moldados com solo-cimento-injetável, em Presidente Wenceslau/SP. In. VI Simpósio Nacional de Controle de Erosão. ABGE. Presidente Prudente-SP. Anais... (CD ROOM).

GALERANI, $C$. et al. Controle de erosão urbana. In: TUCCi,C.E.M., PORTO, R.L.L., BARROS,M.T.Drenagem Urbana. Porto Alegre: Editora da Universidade Federal do Rio Grande do Sul, 1995.Cap.8, p.349-385. 
GALERANI, C. A. (1995) - Descrição das ações de controle de erosão urbana no noroeste do estado do Paraná. In: $5^{\circ}$ Simpósio Nacional de Controle de Erosão. ABGE/UNESP. Bauru-SP. V2. p 69-71.

GARCIAS, C. M. (1997)- Drenagem Urbana In: FREDRICH, R., OBLADEN, N. L., AISSE, M. M. \& GARCIAS, C. M. -Drenagem e Controle da Erosão Urbana. Curitiba: Editora Ibrasa/Champagnat, Cap.5, p.271-327.

GRECCHI, R. C. \& PEJON, O., (1998)- Estudos geoambientais da região de Piracicaba $(S P)$, focalizando o problema da erosão linear, com auxílio do Sistema de Informação Geográfica - IDRISI. In: SIMPÓSIO NACIONAL DE CONTROLE DE EROSÃO, 6, Presidente Prudente, SP. 1998. Anais...(cd-rom). ABGE.

GOMES, D. M. (2001) - Erosão: Aspectos Conceituais, Avaliação e Evolução do Fenômeno. Seminários Gerais em Geotecnia - SGS-833. EESC/USP. São Carlos - SP.

GOLDSTEIN, U. (1998) - Geossintéticos em Controle de Erosão- Curso sobre Aplicações de Geossintéticos em Geotecnia e Meio Ambiente. Instituto de Engenharia. São Paulo (SP) GUERRA, A. T.(1972)- Dicionário geológico-geomorfológico. Rio de Janeiro. IBGE, $4 e d, 439 p$.

GUERRA, A. J. T. \& CUNHA, S. B. (1995)-Geomorfologia: Uma Atualização de Bases e Conceitos. 2a-Edição.Editora Bertrand Brasil. Rio de Janeiro - RJ.

GENOVEZ, A.M. (2003) - Vazões Máximas. In: PAIVA,J.B.D \& PAIVA, E. M. C.D Hidrologia aplicada 'a gestão de pequenas bacias hidrográficas. Porto Alegre: ABRH(Associação Brasileira de Recursos Hídricos). Cap.3, p.33-112.

HIGGINS, C. G.; HILL,B.R. \& LEHHE,A.K. (1990)- Gully Development, Colorado, U.S. Geological Society of América Special Paper 252, Chapter 6 p.139-155.

HERRMANN,H., FRANCICANI,E.M. ,CAVALEIRO,F.(1994)- Boçoroca: uma visão legal. In Congresso Brasileiro de Geologia,38, Balneário Camboriú (SC). Anais...São Paulo: SBG, 1994. p. 187-188.

INSTITUTO DE TECNOLOGIAS DO ESTADO DE SÃO PAULO -IPT (1989)-Controle de Erosão: Bases Conceituais e Técnicas, Diretrizes para o Planejamento Urbano e Regional. Orientação para o Controle de Boçorocas Urbanas. Instituto De Pesquisas Tecnológicas. São Paulo.

IPT (1991)- Orientações para o combate à erosão no Estado de São Paulo - Bacia do Médio Tietê. Convênio DAEE/IPT. São Paulo.3v.(IPT Relatório, 29004). 
IPT (1993)- Diagnóstico e recomendações sobre a boçoroca do Córrego Tuncum, município de São Pedro, SP. São Paulo. (IPT Relatório, 31675).

IWASA, O. Y \& PRANDINI, F. L. (1980) - Diagnóstico da Origem e Evolução das Boçorocas: condição fundamental para a preservação e correção. In Simpósio sobre o Controle de Erosão. ABGE. p 05-34. Curitiba-PR.

IWASA, O. Y., (1995)- Mini Curso: erosão urbana. In: Apostila de curso pré-simpósio Simpósio Nacional de Controle de Erosão, 5, 1995, Bauru. São Paulo: ABGE.

IWASA, O. Y. \& FENDRICH,R. (1998) -Controle de Erosão Urbana In: Geologia de Engenharia, São Paulo. ABGE, 1998. P.271-281.

KERTZMAN, F., PASTORE, E. \& RIDENTE JUNIOR, J. - Dique drenante como solução para combate a boçoroca urban,.In: In: $5^{\circ}$ Simpósio Nacional de Controle de Erosão. ABGE/UNESP. Bauru-SP. V2. p 69-71.

KOERNER, R.M. (1990)- Designing with geosynthetic, $2^{\text {nd }}$ Ed., Prentice Hall Publ. Co. Englewood Cliffs, NJ.

KRONEN, M. A.(1990)- A erosão do solo de 1952 a 1985 e seu controle no Paraná. Boletim Paranaense de Geografia, V. 6/7, p3-16.

LAL, R. (1990) - Soil erosion in the tropics: principles and management. McGraw-Hill. New York. 580 pg.

LAL, R. (2001) - Soil degradation by erosion. Land degradation \& development. No 12. p.519-539.

LIMA, J.M., CURI, N., RESENDE. M \& SANTANA, D. P (1990)- Dispersão do material de solo em água para avaliação indireta da erodibilidade de latossolos. Ver. Brarileira de Ciência do Solo, 14:85-90.

LOLLO, J. A . (1996) - O uso de técnicas de avaliação do terreno no processo de elaboração do mapeamneto geotécnico: sistematização e aplicação na quadrícula de Campinas. Tese de Doutorado. EESC/USP. São Carlos.

MATTOS, N. J. R. (1995)- Técnicas na execução de obras para controle de erosão com estruturas de aço corrugado. In: $5^{\circ}$ Simpósio Nacional de Controle de Erosão. ABGE/UNESP. Bauru-SP. V2. p 119-121.

MACHADO, L. (1995) - As estruturas em gabiões na prevenção e combate à erosão. In: $5^{\circ}$ Simpósio Nacional de Controle de Erosão. ABGE/UNESP. Bauru-SP. V2. p 119-121. 
MACHADO, R. E. (2002)- Simulação de escoamento e de produçào de sedimentos em um microbacia hidrográfica utilizando técnicas de modelagem e geoprocessamento. Tese de Doutorado. ESALQ/SP.

MAGALHÃES, R. A. (2001) - Erosão: definições, tipos e formas de controle. In: VII Simpósio Nacional de Controle de Erosão. ABGE. Goiânia-GO. Anais... (CD ROOM).

MARTINS, J.R.S (1995)- Obras de Macrodrenagem. In: TUCCI, C. E. M, Porto, R.L.L. \& BASTOS, M. T. - Drenagem Urbana. Porto Alegre: Editora da Universidade Federal do Rio Grande do Sul, 1995. Cap.5, p.167-240.

MENEGUETTE, A. (2000) - Introdução ao Geoprocessamento. Courseware em Ciências Cartográficas UNESP/Campus de Presidente Prudente.

MORGAN, R. P. C. (1986) - Soil erosion and conservation. Longman Group. Inglaterra. 289p.

MORGAN, R. P. C. (1996) - Erosion y conservación delsuelo. Ediciones Mundi-Prensa. Madrid. 343p.

MORGAN, R. P. C. \& RICKSON,R.J (1995)- Slope satabilization and erosion control: a bioengineerin approach. Londom: Published E \& FN SPON, p. 274.

NISHYAMA, L. (1995) - Erosão do Solo: uma visão integrada dos fatores e processos que condicionam o seu desenvolvimento. Seminários Gerais em Geotecnia - SGS- 833, EESC/USP. São Carlos - SP.

NISHYAMA, L. (1998) - Procedimento de Mapeamento geotécnico como base para Análises e Avaliações Ambientais do Meio Físico, em escala 1: 100.000 : Aplicação no Município de Uberlândia. Tese de Doutorado. EESC/USP. São Carlos - SP.

NOGUEIRA, J. B. (1998)- Mecânica dos solos- Ensaios de laboratório. Departamento de Geotecnia- Escola de Engenharia de São Carlos- USP. 248p.

ODURO-AFRIYIE, K. (1996) - Rainfall erosivity map of Ghana. Geoderma. No 74. Elsevier. p 161-166.

OLIVEIRA, M.A.T (1995)- Observações de marcas de erosão e cadastramento de voçorocas em meio rural. In: Anais do $5^{\circ}$ Simpósio de Controle de Erosão. Bauru-SP.253255.

OLIVEIRA, A.M.S. (1994). Depósitos tecnogênicos e assoreamento de reservatórios. Exemplo do reservatório de Capivara, Rio Paranapanema, SP/PR. 2 v. (Tese de Doutoramento. Departamento de Geografia da FFLCH-USP). 
OLIVEIRA, L.E.,TERNO, A.W., MANFREDINI, C. (2001)- Tecnologia para prevenção e controle de erosão em vias urbanas, na região do vale do Paraíba, SP, através da contrução de pavimentos de baixo custo. In: VII Simpósio Nacional de Controle de Erosão. ABGE. Goiânia-GO. Anais... (CD ROOM).

OWOPUTI, L. O. \& STOLTE, W. J. (2001) - The role of seepage in erodibility. Hydrological Process. Elsevier. No 15. p 13-22.

PRADINI, F.L. \& NAKAZAWA.V.A -A erosão Urbana, algumas considerações. In: $V$ Simpósio Nacional de Controle de Erosão. ABGE. Bauru-SP. Anais p 95.

PEJON, O. J. (1992) - Mapeamento Geotécnico Regional da Folha de Piracicaba-SP (Escala 1: 100.000): Estudo de Aspectos Metodológicos, de Caracterização e de Apresentação de Atributos. Tese de Doutorado: EESC/USP. São Carlos - SP.

PEJON, O. J.\& ZUQUETTE, L. V. (2001) - Carta de predisposição a erosão aceleradaárea de Piracicaba, estado de São Paulo, Brasil: metodologia e avaliação dos resultadosGeotecnia $n^{\circ} 93.36-60 p$.

PEREIRA, O.NACISMENTO, L.F (1997)- Projetos de tecnologia de infra-estrutura urbana- das fases de analise econômica e licenciamento á gestão ambiental. In ENEGEP 97, Gramado,06 a 09/10/97.

PICHLER, E. (1953). Boçorocas. Boletim da Sociedade Brasileira de Geologia - SBG, 2 (1): p.3-16.

PEREIRA, A. R. (2001) - Controle e recuperação de processos erosivos com técnicas de bioengenharia. In: VII Simpósio Nacional de Controle de Erosão. ABGE. Goiânia-GO. Anais... (CD ROOM).

PINTO, S. F. A. (1998)-Geoprocessamento aplicado à caracterização de indicador da erosão do solo: Exemplo da Bacia Hidrográfica Do Ribeirão Claro (SP). In: VI Simpósio Nacional de Controle de Erosão. ABGE. Presidente Prudente-SP. Anais... (CD ROOM).

PINTO, J. P. Q. (2001) - Erosão dos solos tropicais e seu controle: exemplo do Estado de São Paulo. In: VII Simpósio Nacional de Controle de Erosão. ABGE. Goiânia-Go. Anais... (CD ROOM).

PONTES, A.B.(1980)- Controle da erosão em áreas urbanas. In: Simpósio Nacional de Controle de Erosão, 1. São Paulo, 1980. Anais... São Paulo, ABGE.. P. 35-83.

PONÇANO, W. L., SALOMÃO, F. X. T., KERTZAM, F. F. \& IWASA, O. Y. (1983) Discriminação de Áreas com Diferentes Suscetibilidades à Erosão por Boçorocas e Ravinas 
na Bacia do Peixe. Paranapanema-SP. In: IV Congresso Brasileiro de Geologia de Engenharia. São Paulo-SP. V2. p 423-430.

PONÇANO, W. L. \& PRANDINI, F. L. (1987) - Boçorocas no Estado de São Paulo: Uma Revisão. In. Anais do $4^{\circ}$ Simpósio Nacional de Controle de Erosão. Marília - SP. p 149-175.

POESEN, J.: NACHTERGAELE, J.: VERSTRAETEN,G. \& VALENTIN, C.(2003)- Gully erosion and environmental change: importance and research needs- Catena 50. p91-133.

PORTO, R.L.L. \& AZEVEDO,L.G.T (1997)- Sistema de suporte a decisão aplicada a problemas de recursos hídricos. In: Porto, R. L.L. - Técnicas Quantitativas para o Gerenciamento de Recursos Hídricos. Porto Alegre: Editora da Universidade Federal do Rio Grande do Sul. Cap.2, p.42-95.

PORTO, R.L.L, ZAHEH FILHO, K, TUCCI, C.E.M. \& BIDONE, F. (2001)- Drenagem Urbana. In: TUCCi,C.E.M. et al. Hidrologia -ciência e aplicação. Porto Alegre: Editora da Universidade Federal do Rio Grande do Sul, 2001.Cap.21, p.805-842.

RAMOS, C. L. (1995)- A erosão urbana no contexto dos sistemas de drenagem In. V Simpósio Nacional de Controle de Erosão. ABGE. Bauru-SP. Anais p 101-103.

RODRIGUES, J. E. (1982)- Estudos de Fenômenos Erosivos Acelerados - Boçoroca. Tese de Doutorado: EESC/USP. São Carlos - SP.

RODRIGUES, J. E. \& VILAR, O. M. (1984) - Estudos da erosão interna em boçorocas através da teoria do carreamento. In: $4^{\circ}$ Congresso Brasileiro de Geologia de Engenharia. Belo Horizonte. Anais, v2. ABGE. p 163-169.

RODRIGUES, B. B. (1998) - Inventário e Análise de Susceptibilidade aos movimentos de Massa Gravitacionais e Erosões na Região de Águas de Lindóia - SP - Escala 1: 10.000. Tese de Mestrado: EESC/USP. São Carlos - SP.

RODRIGUES, R. (1995) - Erosão em rodovias: problema a ser resolvido. In: $5^{\circ}$ Simpósio Nacional de Controle de Erosão. ABGE/UNESP. Bauru-SP. V2. p 93-94.

RHODIA-SATER (1997) - Geossintéticos (Cd-room).

RIGHETTO, A.M. (1998) - Hidrologia e recursos hídricos. São Carlos: EESC/USP. P. 819 RIDENTE JUNIOR., J. L., STEIN, D. P., IWASA, O. Y., OLIVEIRA, A. M. S., ALTAFINI, M., (1995 )- Carta de risco de erosão da área urbana de Botucatu, SP. In. SIMPÓSIO NACIONAL DE CONTROLE DE EROSÃO, 5,1995, Bauru. Resumos expandidos. São Paulo: ABGE, 1995. p.161.

RIDENTE JUNIOR, J. L.,. CANIL, K., IWASA, O.Y., CERRI, L. E. S., AUGUSTO FILHO, O. A., (1998 ${ }^{a}$ - Risco potencial de erosão da área urbana e periurbana de São 
José do Rio Preto, SP). In. SIMPÓSIO NACIONAL DE CONTROLE DE EROSÃO, 6, Presidente Prudente, SP. 1998. São Paulo. Anais.(cd-rom). ABGE.

RIDENTE JUNIOR, J. L... GAMA JUNIOR, G. F. de C., GOMES, C. L. R., IWASA, O.У., (1998b) - Plano de obras de controle de erosão urbana, nas bacias dos córregos limoeiro e cedro (Presidente Prudente e Álvares Machado). In: SIMPÓSIO NACIONAL DE CONTROLE DE EROSÃO, 6, Presidente Prudente, SP. 1998. São Paulo. Anais.(cd-rom). ABGE.

RIDENTE, J.L.J (2000)- Prevenção e Controle da Erosão Urbana: Bacia do Córrego do Limoeiro e Bacia do Córrego do Cedro, Municípios de Presidente Prudente e Álvares Machado, SP- Tese de Mestrado. UNESP. Rio Claro- SP.

RIDENTE JUNIOR, J. L. \& ALMEIDA FILHO, G. S. (2001) - Mini-Curso 1: Diagnóstico, Prognóstico e Controle de Erosão In: VII Simpósio Nacional de Controle de Erosão. ABGE. Goiânia-GO.

SÁ, C. A. (2001) - Mapeamento de Declividades voltado para o Controle de Processos Erosivos em Sítios Florestais. Monografia de Especialização. Universidade Federal de Minas Gerais. Belo Horizonte - MG.

SALOMÃO, F. X. T. \& IWASA, O. Y - (1995) - Erosão e ocupação rural e urbanaSão Paulo, curso de geologia Aplicada ao Meio Ambiente. IPT/ABGE.

SANTOS, W. D. (1981)- Erosão urbana do noroeste do Paraná. In: II Simpósio Nacional de Controle de Erosão. ABGE. São Paulo. Anais... v1, p.51-74..

SANTOS, I. \& GOMES, J. (1998)- Caracterização do Índice de Erosividade da Porção Oriental do Estado do Paraná. In: VI Simpósio Nacional de Controle de Erosão. ABGE. Presidente Prudente-SP. Anais... (CD ROOM).

SANTOS, A.R. \& NAKAZAWA, V.A (1992)- Erosão e assoreamento na RMSO. In: Seminário Problemas Geológicos e geotécnicos na Região Metropolitana de São PauloRMSP,1,1992,São Paulo. Anais.. São Paulo: ABGE, 1992. P.177-194.

SANTORO, J. (1991) - Fenômenos Erosivos acelerados região de São Pedro-SP. Estudo da fenomenologia com ênfase geotécnica. Dissertação de Mestrado. IGCE - UNESP. Rio Claro. 139p

SANTORO, J. (2000) - Análise da ocorrência de processos erosivos no município de Campinas (SP), a partir da interação entre a suscetibilidade natural à erosão hídrica e o uso e ocupação do solo. Tese de Doutorado. UNESP. Rio Claro - SP. 
SÃO PEDRO (1995) Decreto n. 2.955/95, de 7 de fevereiro de 1995. Declara "Estado de Alerta" no Município de São Pedro e da outras providencias.

SELBY, M. J. (1993) - Hillslope Material and Process. Oxford University Press. Second Edition. Oxford.

SEROA DA MOTTA (1997)- Ronaldo. Manual para Valoração Econômica de Recursos Ambientais. IPEA/MMA/PNUQ/CNPq. Rio de Janeiro. RJ. 1997.

SIGRH- Banco de dados pluviométricos do estado de São Paulo- Dados do Município de São Pedro (www.sigrh.sp.gov.br)

SILVA, M. L. N, CURI, N., LIMA, J. M \& FERREIRA, M. M. (2000)- A avaliação de Métodos Indiretos de Determinação da Erodibilidade de Latossolos Brasileiros- Pesq. Agropec. Brás. Brasília, v.35, n6, p.1207-1220, jun. 2000.

SILVA, T.R.M \& LACERDA, W. ${ }^{a}$ (2001)- Erodibilidade dos Solos de um Voçoroca da Região de Ouro Preto, Minas Gerais. In: VII Simpósio Nacional de Controle de Erosão. ABGE. Goiânia-Go. Anais... (CD ROOM).

SILVA, A. M., SILVA, M.L.N, CURI, N, LIMA, J. M., BARRETTO, V.C.M. \& SILVA,T.F.(2001)- Perdas Por Erosão e Erodibilidade de Cambissolo e Latossolo Roxo no Sul de Minas Gerais - Resultados Preliminares. In: VI Simpósio Nacional de Controle de Erosão. ABGE. Presidente Prudente-SP. Anais... (CD ROOM).

SILVA, A. F. (2002) - Erosão Hídrica dos Solos: Fatores Intervenientes, Modelagem e Mapeamento. Seminários Gerais em Geotecnia - SGS-833. EESC/USP. São Carlos - SP.

SILVA, A. F. (2003) - Mapeamento Geotécnico e análise dos Processos Erosivas na Bacia do Córrego Tucum, São Pedro-SP, Escala 1:10.000- Dissertação de Mestrado. Departamento de Geotecnia EESC/USP. USP- São Carlos - SP. 133p.

SILVA, H. A.A.(2002)- Controle de processos de movimento de massa com utilização de tecnologia em Bioengenharia.:In: $X$ Congresso Brasileiro de Geologia de Engenharia Ambiental . Anais... (CD ROOM).

SILVEIRA, L. L. (2002)- Elaboração de Carta de Susceptibilidade à erosão das bacias dos rios Araraquara e Cubatão, Escala 1:50.000 (Volume 1) - Tese de Mestrado. EESC/USP. São Carlos - SP.

SUDO,H. (1998)- O conceito de sistema e a estrutura físico-antrópica dos processos erosivos. In. VI Simpósio Nacional de Controle de Erosão. ABGE. Presidente Prudente-SP. Anais... (CD ROOM). 
SOUZA, M. L. de (2001) - Proposta de um Sistema de Classificação de Feições Erosivas voltados à Estudos de Procedimentos de Análises de Decisões quanto a Medidas Corretivas, Mitigadoras e Preventivas: Aplicação no Município de Umuarama (PR). Tese de Doutorado. UNESP. Rio Claro- SP.

SOIL SCIENCE SOCIETY OF AMÉRICA (2001)- Glossary of soil science terms. Soil Science Society of Ameica, Madison, WI, http://www.soil.org/sssagloss

STEIN, D. P. (1995) - Diagnóstico de Erosão. In: $5^{\circ}$ Simpósio Nacional de Controle da Erosão. ABGE/UNESP. Bauru-SP.V5. p 55-57.

TUCCI. C. E. M \& COLLISCHONN. W (1998)- Drenagem urbana e controle de erosão. In: VI Simpósio Nacional de Controle de Erosão. ABGE. Presidente Prudente-SP. Anais... (CD ROOM).

TUCCI, C. E. M. \& GENS,F. (1995)- Controle do impacto da urbanização. In: TUCCi,C.E.M., PORTO, R.L.L., BARROS,M.T.Drenagem Urbana.: Editora da Universidade Federal do Rio Grande do Sul- Porto Alegre, 1995.Cap.7, p.277-327.

TUCCI, C. E. M. et al (2001) - Hidrologia - ciência e aplicação. Editora da Universidade Federal do Rio Grande do Sul - Porto Alegre, 2001.

VAZ, J. C. (1997) - Geoprocessamento. Ação Administrativa. BNDES. Dicas, n 94. 4p.

VANDAELE,K.: POESEN,J.: GOVERS, G.\& WESEMAEL,B.V. (1996)- Geomorphic threshold conditions for ephemeral gully incision. Geomorfology $n^{\circ} 16, p$ 161-173.

VERTAMATTI, E. \& ARAÚJO, F. A. R DE (1990)-Critérios para previsão do potencial erosivo dos solos tropicais. In: $24^{a}$ Reunião Anual de Pavimentação. Belém - PA. p 327-347. VIKTOR,LEINZ. \& LEONARDOS,O.H.(1971)- Glossário Geológico com a correspondente terminologia em inglês, alemão e francês. Companhia Editora Nacional- São Paulo/SP 236p.

VIDAL, I. G. (1995) - Geogrelha e hidrossemeadura no controle de erosão. In: $5^{\circ}$ Simpósio Nacional de Controle de Erosão. ABGE/UNESP. Bauru-SP. V2. p 131-133.

VILAR, O.M.et al. (1984)- A aplicabilidade dos solos reforçados ao controle de boçorocas. In: Congresso Braslleiro de Geologia de Engenharia, IV, Belo Horizonte, Anais... São Paulo: ABGE, p.317-324.

VALÉRIO FILHO, M. \& ARAÚJO JÚNIOR, G. J. L (1995) - Técnicas de geoprocessamento e modelagem aplicadas no monitoramento de áreas submetidas aos processos de erosão no solo. In: $5^{\circ}$ Simpósio Nacional de Controle de Erosão. ABGE/UNESP. Bauru-SP. V2. p 279-282. 
VEDOVELLO, R., BROLLO, M.J. \& SILVA, P.C.F (1998)- Avaliação da erosão como fator condicionante na seleção de área para disposição de resíduos. Uma abordagem a partir de compartimentação fisiográfica obtida em imagem de satélite. In: VI Simpósio Nacional de Controle de Erosão. ABGE. Presidente Prudente-SP. Anais... (CD ROOM).

VILAR. O. M. (1987) - Formulação de um Modelo Matemático para Erosão dos Solos pela Chuva.Tese de Doutorado. EESC/USP. São Carlos - SP.

WINPENNY,J. T. (1991)- Values for the environment: A Guide to Economic Appaisal. Londres Overseas developmente Institute.

WILSON, N. B. (2001) - Development of fundamentally based detachment model. Transaction of the ASAE. V36. N ${ }^{\circ}$ 4. p 1105-1114.

ZACHAR, D. (1982). Soil erosion. Amsterdam; New York: Elsevier Scientific. (Série Developments in Soil Science, 10).

ZUQUETTE, L. V. (1987) - Análise Crítica da Cartografia Geotécnica e Proposta Metodológica para as Condições Brasileiras. Tese de Doutorado: EESC/USP. São Carlos $(S P)$.

ZUQUETTE, L.V. \& GANDOLFI, N. (1991) -.Metodologia de mapeamento Geotécnico para Áreas Municipais. In: VI Congresso Brasileiro de Geologia de Engenharia., IV. Belo Horizonte, ABGE. V2.

ZUQUETTE, L. V. (1993) - Importância do mapeamento geotécnico no uso e ocupação do meio físico: fundamentos e guia de elaboração. São Carlos, 2v. Tese (livre Docência)EESC/USP.(SP).

ZUQUETTE, L.V. \& NAKAZAWA, V. A. (1998) - Cartas de Geologia de Engenharia. In: Geologia de Engenharia (ABGE). Edição histórica. P 283-300. São Paulo.

RELATÓRIO DA FAPESP (PROCESSE N 00/03027-7)- Elaboração de cartas de eventos perigosos e riscos associados aos processos erosivos -escala 1:10.000-região de São Pedro(SP): desenvolvimento metodológico, realizado em 2000, pelo prof Dr. Lázaro Zuquette. 


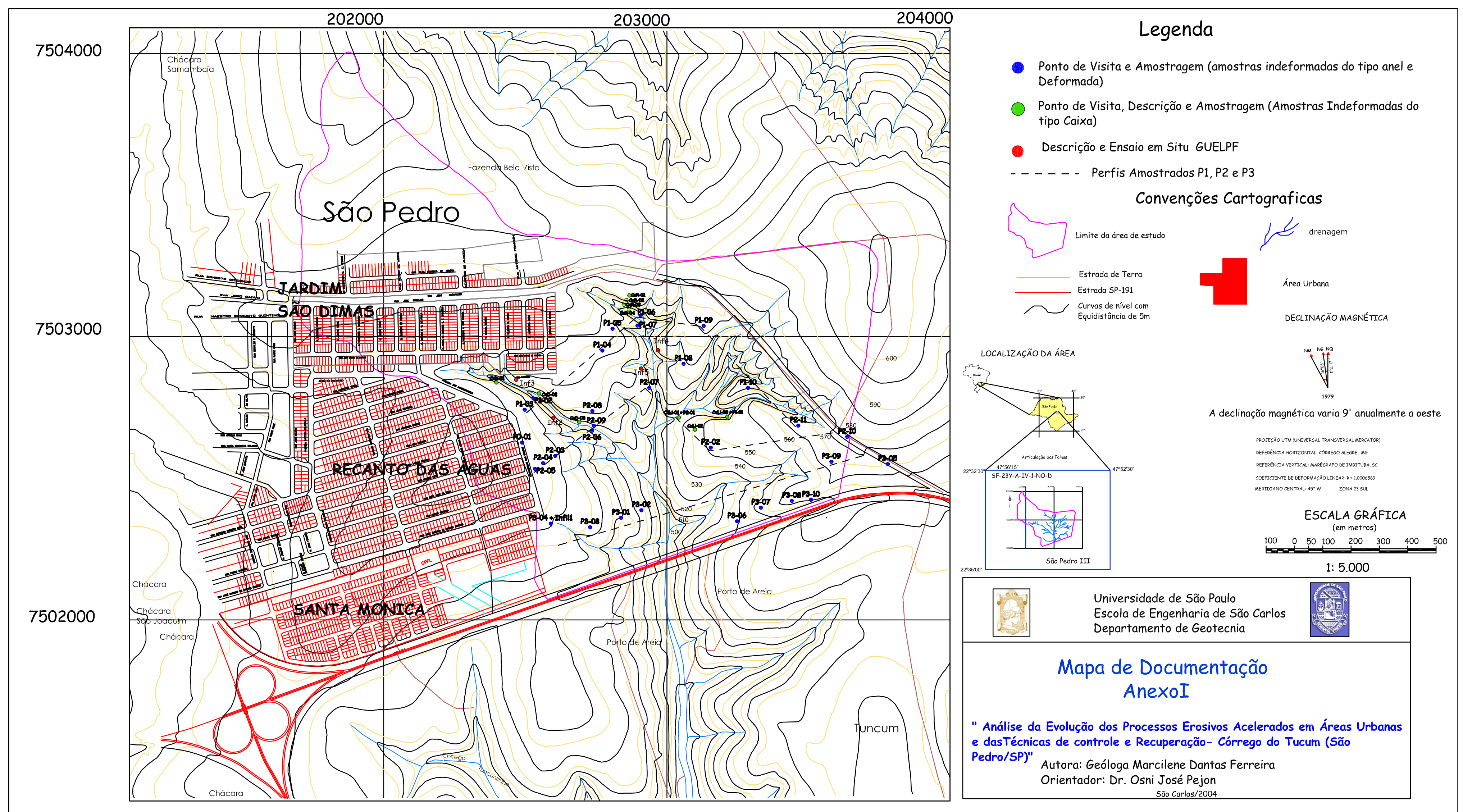




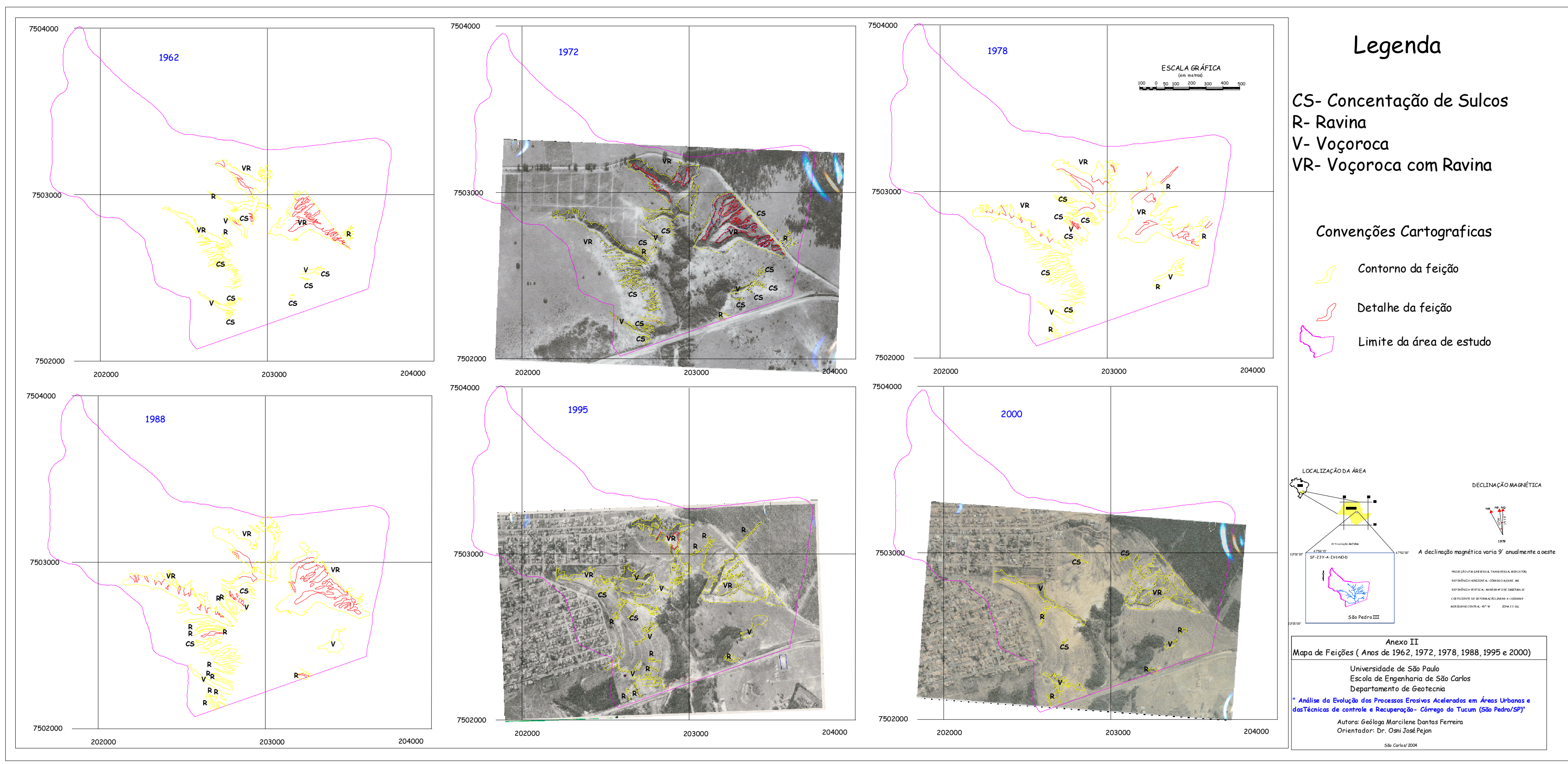




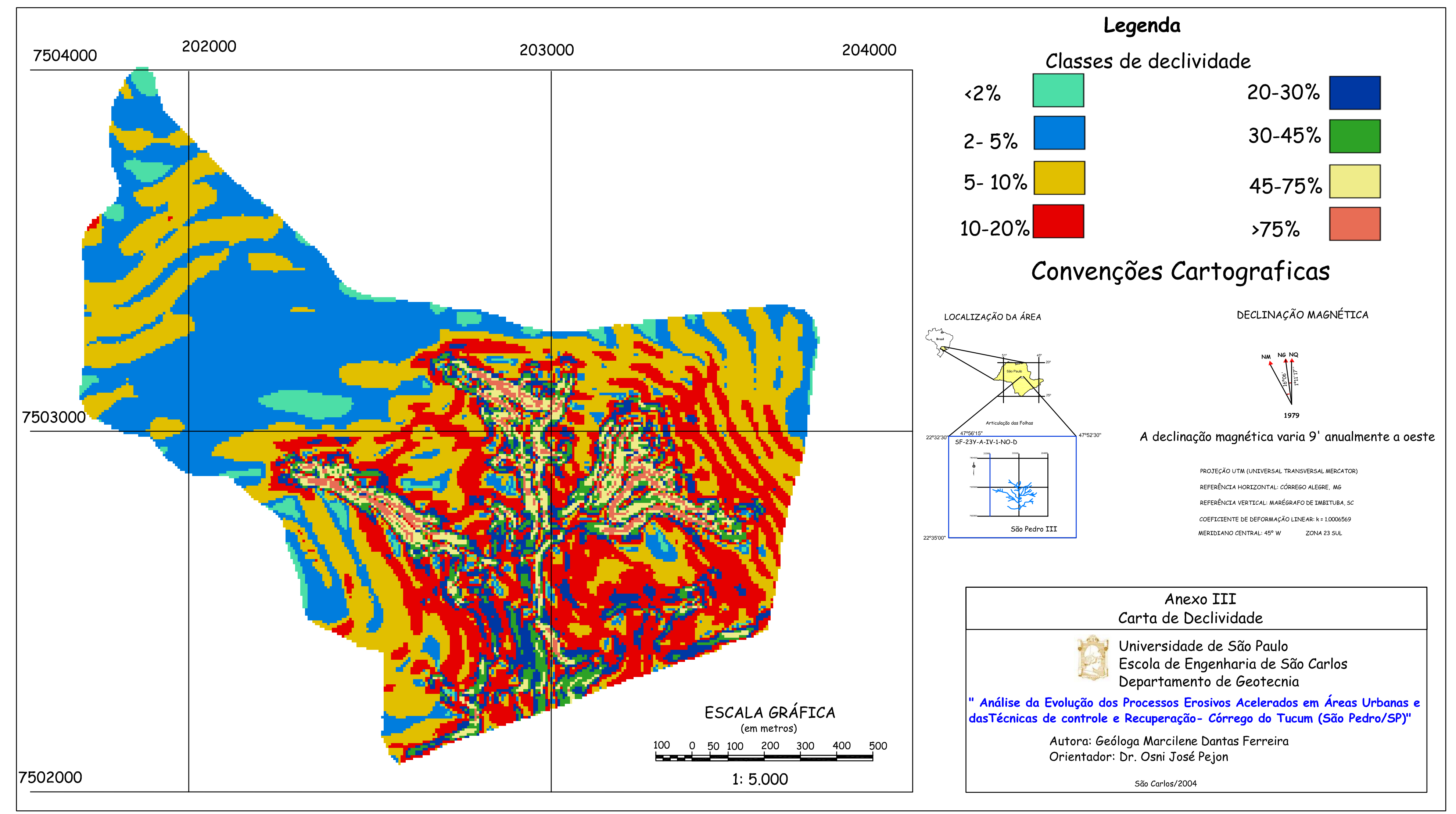




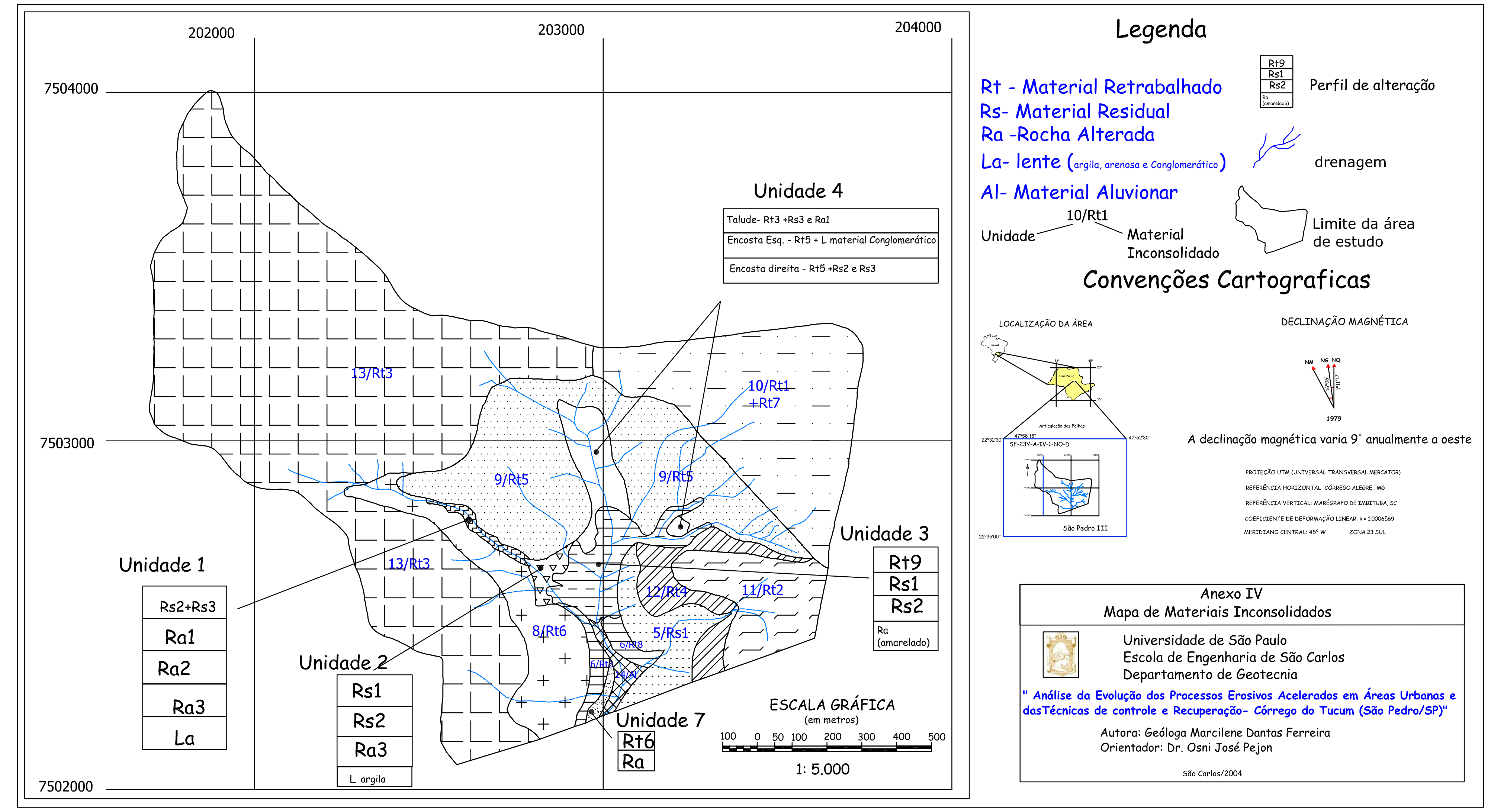




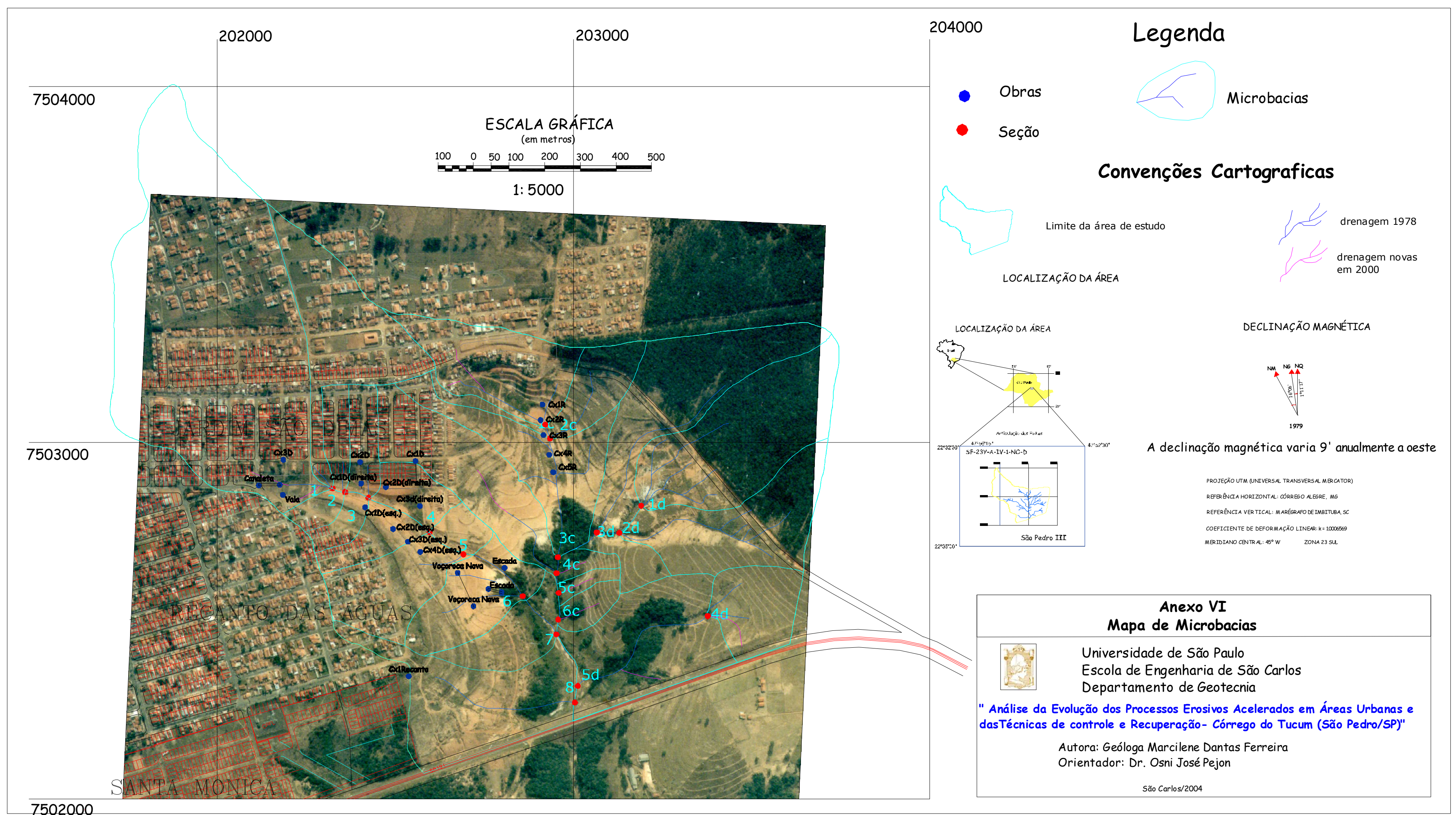




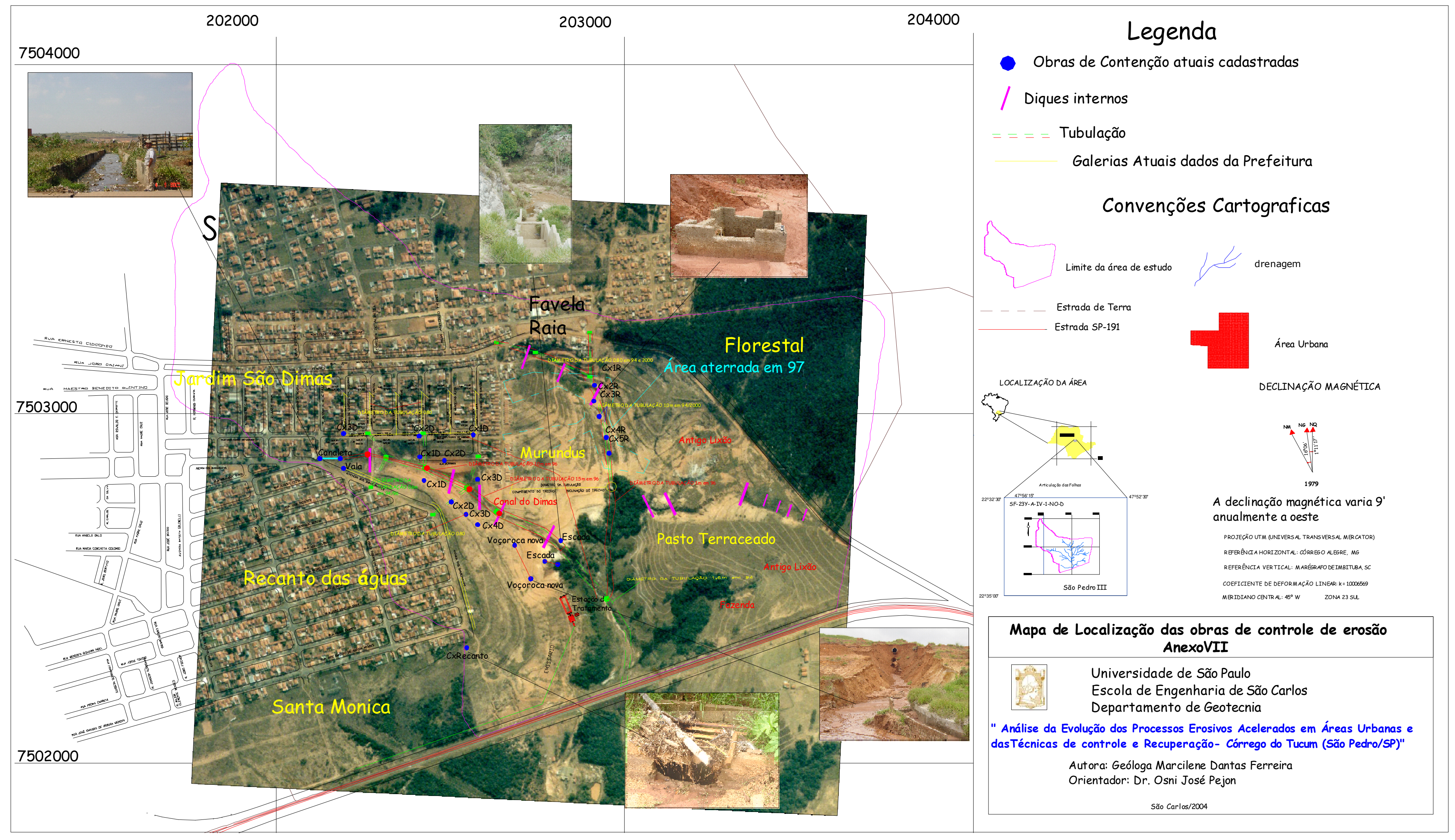

